Portland State University

PDXScholar

$1-1-2011$

Hydrogeology of the McKinney Butte Area: Sisters, Oregon

Joshua Andrew Hackett

Portland State University

Follow this and additional works at: https://pdxscholar.library.pdx.edu/open_access_etds Let us know how access to this document benefits you.

Recommended Citation

Hackett, Joshua Andrew, "Hydrogeology of the McKinney Butte Area: Sisters, Oregon" (2011).

Dissertations and Theses. Paper 371.

https://doi.org/10.15760/etd.371

This Thesis is brought to you for free and open access. It has been accepted for inclusion in Dissertations and Theses by an authorized administrator of PDXScholar. Please contact us if we can make this document more accessible: pdxscholar@pdx.edu. 


\title{
Hydrogeology of the McKinney Butte Area: Sisters, Oregon
}

\author{
by \\ Joshua Andrew Hackett
}

\begin{abstract}
A thesis submitted in partial fulfillment of the
\end{abstract} requirements for the degree of

\author{
Master of Science \\ in \\ Geology: Geohydrology
}

Thesis Committee:

Robert B. Perkins, Chair

Michael Cummings

Kenneth Lite, Jr.

Portland State University

(C) 2011 


\begin{abstract}
McKinney Butte, a late Tertiary andesite vent and flow complex, is located near the town of Sisters, Oregon, in the upper Deschutes Basin, and is situated along the structural trend that forms the eastern margin of the High Cascades graben (Sisters fault zone and Green Ridge). Rapid development and over appropriated surface water resources in this area have led to an increased dependence upon groundwater resources. A primary concern of resource managers is the potential impact of expanding groundwater use on stream flows and spring discharge. Two sets of springs (McKinney Butte Springs and Camp Polk Springs) discharge to Whychus Creek along the east flank of McKinney Butte, and during low-flow conditions supply a substantial component of the total flow in the creek. Despite their contribution to Whychus Creek, the springs along McKinney Butte are small-scale features and have received less attention than larger volume $\left(>2 \mathrm{~m}^{3} / \mathrm{s}\right)$ springs that occur in the basin (i.e., Metolius Spring and Lower Opal Springs).

This study used discharge measurements in Whychus Creek upstream and downstream of the springs, and mixing models using measurements of electrical conductivity and temperature in the springs and Whychus Creek to determine the contribution of the springs to the creek. Isotopic, thermal, and geochemical signatures for the McKinney Butte and Camp Polk Springs, and local streams (Whychus Creek and Indian Ford Creek) and springs (Metolius Spring, Paulina Spring, Alder Springs, and Lower Opal Spring) were assessed to determine the source(s) of the McKinney
\end{abstract}


Butte and Camp Polk Springs. The discharge and hydrochemical data along with hydraulic head data from local wells were used in the development of a conceptual model of groundwater flow for the McKinney Butte area.

Discharge from the McKinney Butte Springs supplies the majority of water to Whychus Creek on the east flank of McKinney Butte $\left(\sim 0.20 \mathrm{~m}^{3} / \mathrm{s}\right)$, provides up to $46 \%$ of the flow in the creek, and is relatively stable throughout the year. Discharge from the Camp Polk Springs is less than $0.05 \mathrm{~m}^{3} / \mathrm{s}$.

Isotopic, thermal, and geochemical signatures indicate distinct sources for the McKinney Butte and Camp Polk Springs. Groundwater discharged at the McKinney Butte Springs is depleted in heavy stable isotopes $\left(\delta \mathrm{D}\right.$ and $\left.\delta^{18} \mathrm{O}\right)$ relative to the Camp Polk Springs. Recharge elevations inferred from stable isotope concentrations are 1800-1900 m for the McKinney Butte Springs and 950-1300 m for the Camp Polk Springs. Elevated water temperature in the McKinney Butte Springs relative to the average air temperature at the inferred recharge elevation indicates the presence of geothermal heat and implies deep circulation in the flow system. The temperature in the Camp Polk Springs is not elevated. The Camp Polk Springs, though not the McKinney Butte Springs, contain elevated concentrations of ions $\mathrm{Cl}, \mathrm{SO}_{4}$, and $\mathrm{NO}_{3}$ that are indicative of contamination.

The study results indicate the source of the Camp Polk Springs is shallow groundwater whereas the McKinney Butte Springs discharge water that has circulated deep in the groundwater flow system. Additionally, the hydrochemical traits of the McKinney Butte Springs are similar to Metolius Spring, suggesting discharge from the 
McKinney Butte Springs is controlled by the structural trend that forms the eastern margin of the High Cascades graben. The significant difference in discharge between the McKinney Butte Springs and Metolius spring may be related to the size of faults that occur locally. 


\section{Acknowledgements}

Faculty, colleagues, farmers, friends, and family have helped me to complete this thesis. I would like to express my gratitude to these individuals for their support and assistance.

I would like to begin by thanking my thesis committee; Ben Perkins, Michael Cummings, and Ken Lite for their guidance and encouragement throughout this process. Ben greatly improved my scientific writing and my understanding of geochemistry. His endless patience and understanding will not be forgotten. Michael introduced me to field work and geologic mapping and guided me through an undergraduate thesis, a great preparation for this project. His commitment to education is unmatched. Finally, Ken provided thoughtful editorial comments and always encouraged me to think bigger. He is also responsible for my current employment with the Oregon Water Resources Department. Thank you, Ken.

Next, I would like to thank my colleagues at the Oregon Water Resources Department. Jonathan LaMarche conducted seepage runs for this study, several times under less than desirable conditions. Doug Woodcock allowed ample time to complete this thesis. Marc Norton introduced me to the joys of field work in the Umatilla Basin. I owe a great debt of gratitude to Karl Wozniak for the countless hours he spent during the past three years mentoring me on the subjects of groundwater hydrology and database management. I am truly grateful for the opportunity to have learned from such a gifted thinker. I am also appreciative of his eternal optimism. 
I would like to thank Chester Bradley, a farmer and rancher in Sisters, Oregon, for allowing unrestricted access to the springs on his property. This project would have been dead in the water without him.

I would like to thank my friends and family for their constant support and encouragement. My friends and brothers provided welcome diversions during the writing process. I owe a special debt to my in-laws for watching Basil on numerous occasions while I was completing this project. My parents have supported me in all my endeavors. I thank my dad for always pushing me to be better. I especially thank my mom for her incredible commitment to our family.

I most want to thank my wife, Amy, and my girls, Faith and Basil, for their love and sacrifice. I am forever indebted to Amy and Faith for helping me to find my way; I would not be here without them. I am extremely grateful to Amy for picking up the slack at home during the last several months of this project as I frantically finished writing. Finally, I thank Faith and Basil for inspiring and amazing me every day. 


\section{Table of Contents}

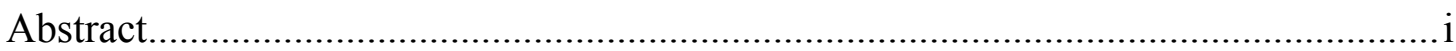

Acknowledgements ................................................................................. iv

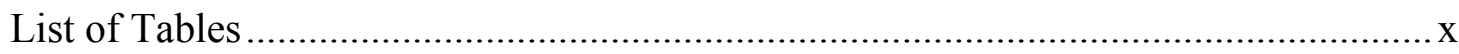

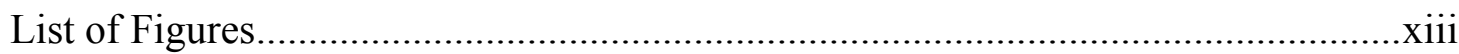

Chapter 1 - Introduction ................................................................................ 1

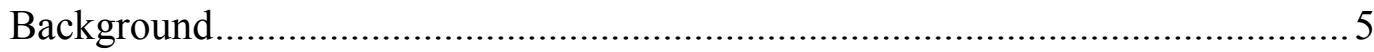

Location and Geography of Study Area ................................................... 5

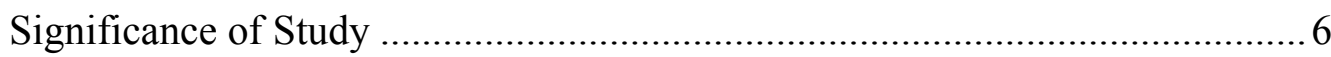

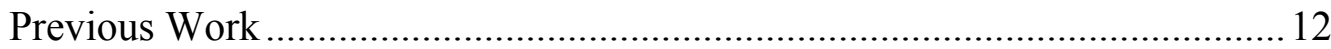

Chapter 2 - Hydrogeologic Framework ............................................................ 15

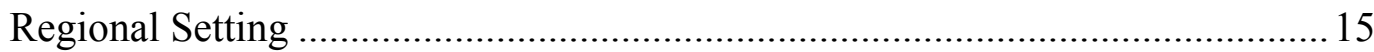

Stratigraphic Units and Hydrogeologic Characteristics ................................. 16

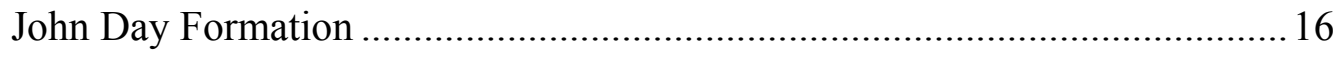

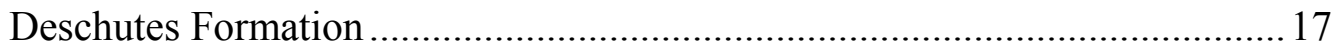

Cascade Range Volcanics.................................................................... 18

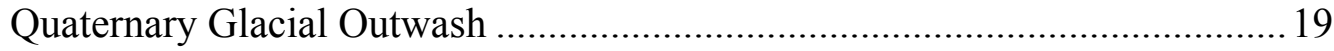

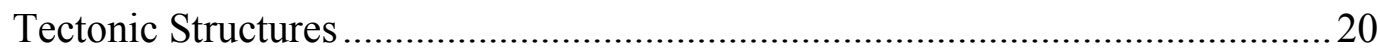

Geologic Controls on the Occurrence of Springs ...........................................2 21

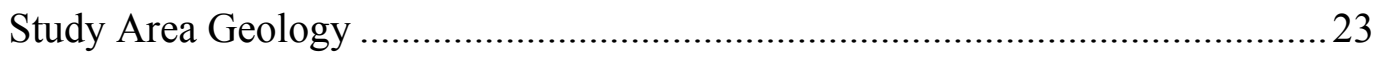

Chapter 3 - Study Design and Methods ............................................................... 26 


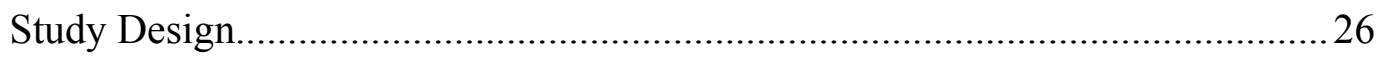

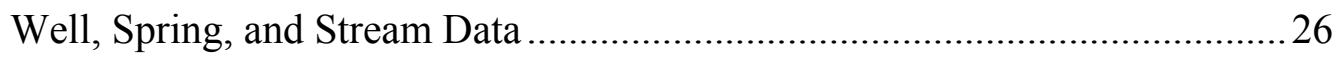

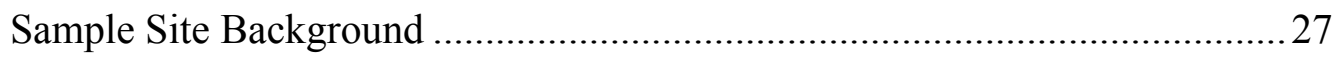

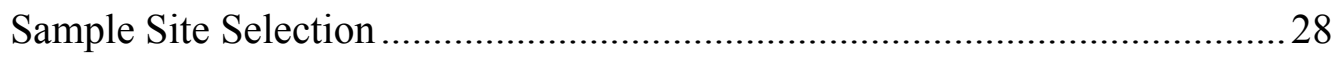

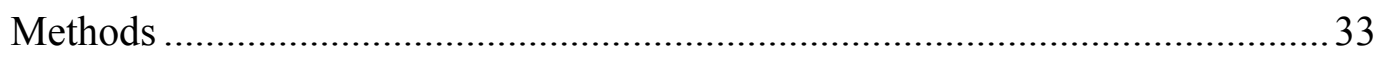

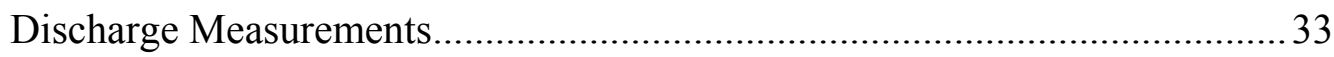

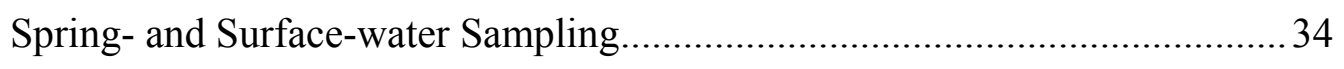

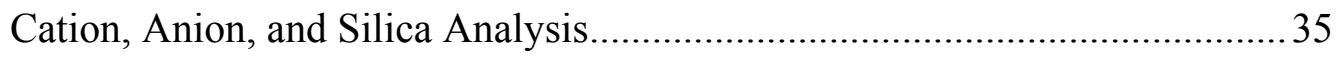

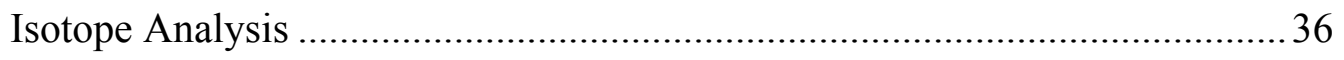

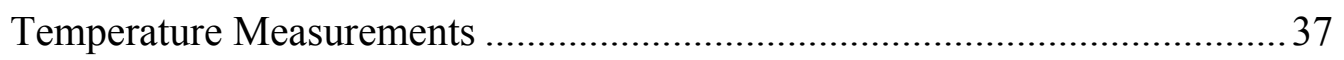

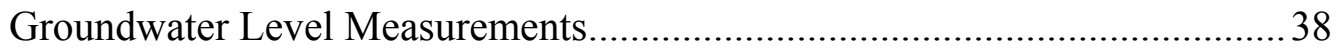

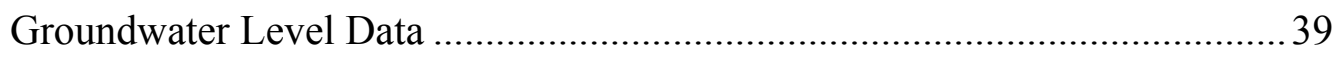

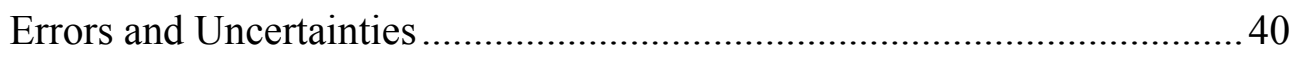

Water Level Elevation Contour Maps.......................................................... 40

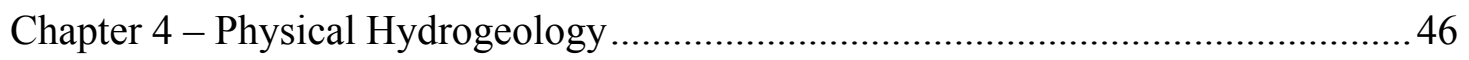

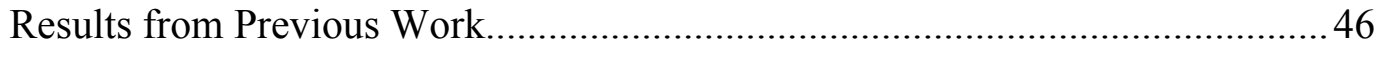

Stream Discharge Measurements .................................................................. 46

Discharge Measurements of Other Significant Springs in the Region..............52

Potentiometric Surface Mapping ...................................................................52

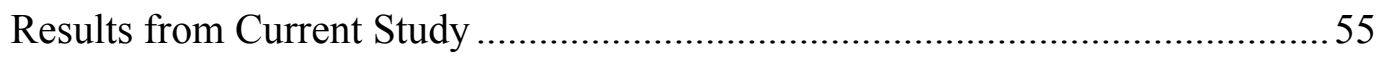

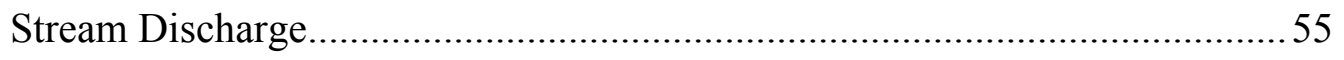

Discharge from the McKinney Butte Springs .................................................. 63 
Groundwater Level Measurements...............................................................66

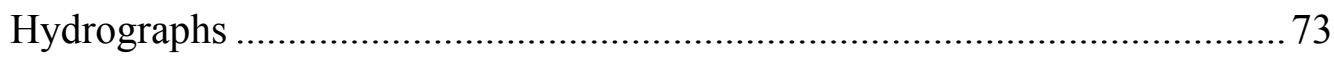

Water Level Contour Mapping....................................................................... 76

Chapter 5 - Chemical Hydrogeology …………………........................................ 79

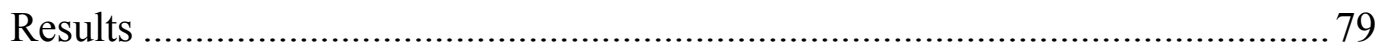

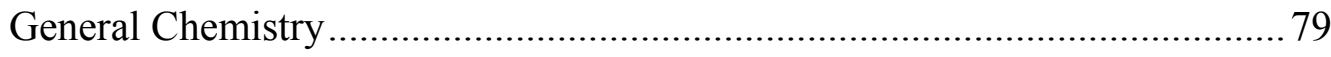

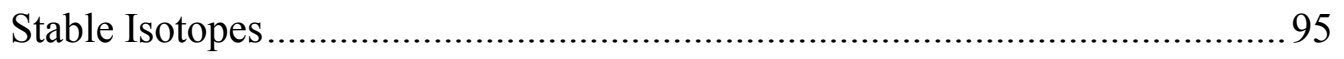

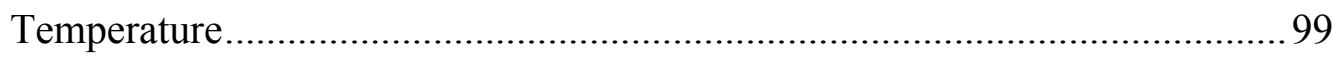

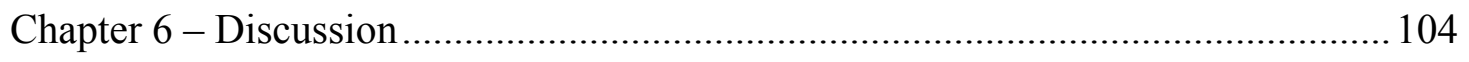

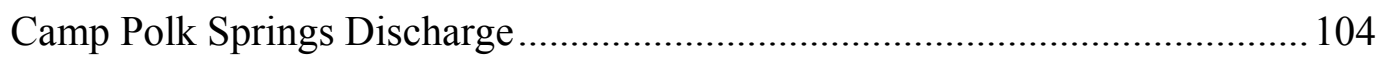

McKinney Butte Springs Discharge ……………………….............................. 104

Discharge Contribution to Whychus Creek.................................................... 116

Thermal Contribution to Whychus Creek ………………….......................... 120

Source of McKinney Butte and Camp Polk Springs .......................................... 122

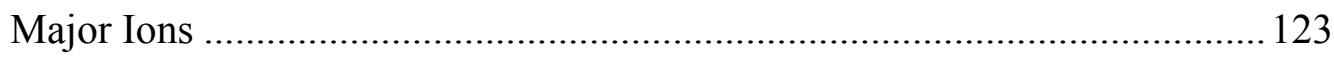

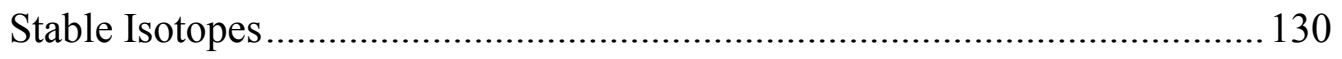

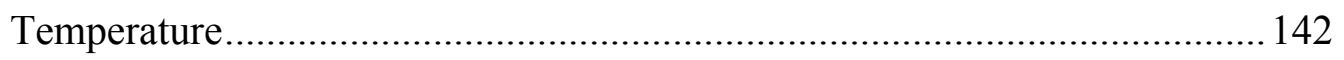

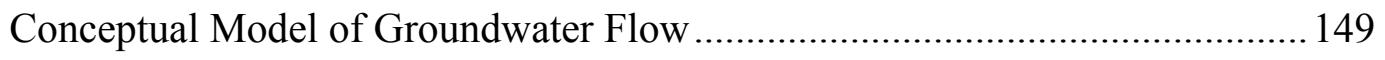

Horizontal Groundwater Flow............................................................... 150

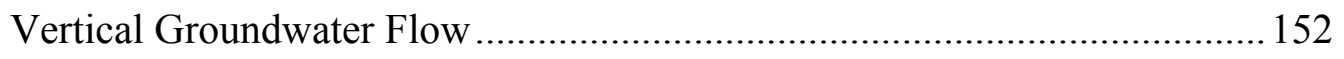

Groundwater Flow to Camp Polk Springs.................................................... 152

Groundwater Flow to the McKinney Butte Springs...................................... 153 
Conceptual Groundwater Flow Model ....................................................... 156

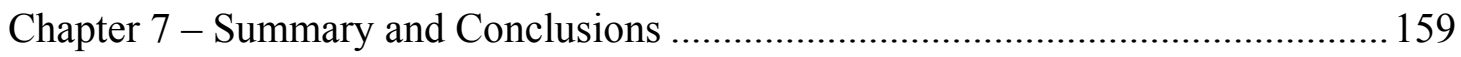

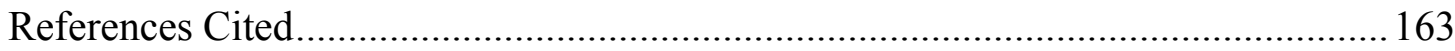

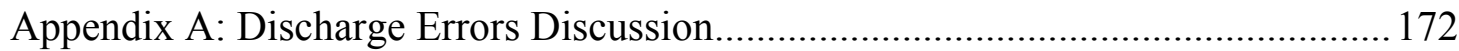

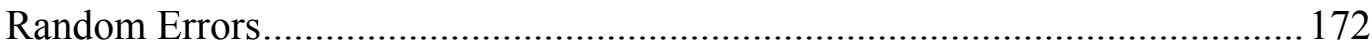

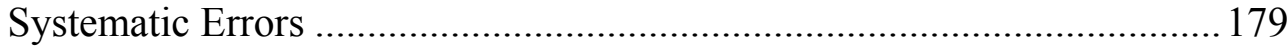

Stream Discharge Variation Errors..................................................................... 183

Appendix B: General Chemistry Error Discussion ................................................... 186

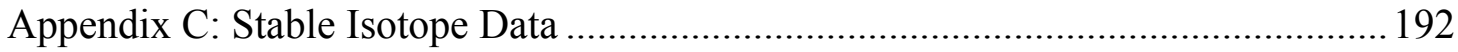




\section{List of Tables}

Table 1. Calibration standard and procedures.

Table 2. Atomic Absorption parameters used for cation analysis. 36

Table 3. Mean water level elevations used to generate the water level elevation contour map for the shallow part of the groundwater flow system. Wells with more water level measurements were considered to be better representations of the hydraulic head.

Table 4. Mean water level elevations used to generate the water level elevation contour map for the deep part of the groundwater flow system. Wells with more water level measurements were considered to be better representations of the hydraulic head.

Table 5. Instantaneous discharge measurements for Whychus Creek (La Marche, personal communication 2007)

Table 6. Instantaneous discharge measurements for Indian Ford Creek (La Marche, personal communication 2007)

Table 7. Discharge values for local springs.

Table 8. Discharge measurements and calculated errors for Whychus Creek. 56

Table 9. Discharge measurements and calculated errors for Indian Ford Creek..........56

Table 10. Measured discharge along Reach 2 of Whychus Creek. 66

Table 11. Location information and summary of field parameters collected sampling locations during the current study and previous studies. Blank records indicate

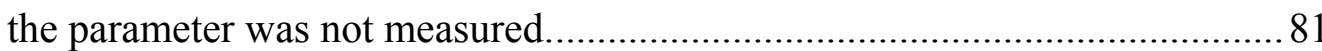


Table 12. Water Chemistry data for samples analyzed during the current study and previous studies. Major ion and silica concentrations are reported in $\mathrm{mg} / \mathrm{L}$. $\delta^{18} \mathrm{O}$ and $\delta^{2} \mathrm{H}$ values are in standard \%o notation. Major ion and silica errors are $<15 \%$ unless otherwise indicated, $\delta^{18} \mathrm{O}$ and $\delta^{2} \mathrm{H}$ errors are $\pm 0.1 \%$ and $\pm 1.0 \%$, respectively. Blank records indicate the parameter was not measured. A complete treatment of errors and uncertainties associated with the determination of major ion concentrations is presented in Appendix B. ........ 83

Table 13. Total ionic concentration for various site types $(\mathrm{mg} / \mathrm{L})$ 87

Table 14. Temperature measurements $\left({ }^{\circ} \mathrm{C}\right)$ collected during water sampling events for study area streams and springs. Average monthly temperatures in the Lamb Well (DESC 54659) are also included. 101

Table 15. Estimates of Discharge from the McKinney Butte Springs. $\mathrm{EC}_{\mathrm{AC}}$ and $\mathrm{EC}_{\mathrm{BF}}$ are electrical conductivities measured in Whychus Creek above Chester Springs and below Frank Springs. $\mathrm{EC}_{\mathrm{MS}}$ is the electrical conductivity measured in Frank Springs and represents electrical conductivity in the McKinney Butte Springs complex. $\mathrm{fEC}_{\mathrm{MS}}$ is the fraction of $\mathrm{EC}$ in Whychus Creek provided by the McKinney Butte Springs as calculated in equation 1; and $\mathrm{Q}_{\mathrm{WCBF}}$ is the discharge in Whychus Creek below Frank Springs measured during seepage runs. $\mathrm{Q}_{\mathrm{MS}}$ is the estimated discharge from the McKinney Butte Springs calculated from electrical conductivity data using equation 2.

Table 16. Sum of Squares (SS) of differences between observed and predicted temperature values at Whychus Creek below Frank Springs for selected estimates of discharge from the McKinney Butte Springs ( $\mathrm{Q}_{\mathrm{MS}}$ ). A discharge of $0.185 \mathrm{~m}^{3} / \mathrm{s}$ is the best fit to the data, and represents the estimated discharge from the McKinney Butte Springs for the period between 08/30/2007 and $10 / 15 / 2007$ 
Table 17. Estimates of discharge from the McKinney Butte Springs (QMS). Discharge was estimated via seepage runs on Whychus Creek and through the use of electrical conductivity and temperature data collected in the McKinney Butte Springs and at locations in Whychus Creek. Measured or calculated discharge estimates are presented along with minimum and maximum discharge values calculated from associated uncertainties.

Table 18. Total acreage covered by irrigation water rights in sections bordering the west side of McKinney Butte and sections on McKinney Butte. Data from Oregon Water Resources Department Water Rights Information System (WRIS) database.

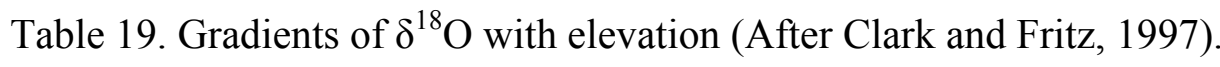
134

Table 20. Spring recharge elevations estimated from the relationship between $\delta^{18} \mathrm{O}$ in precipitation and elevation on the east flank of the central Oregon Cascades.

Table 21. Temperatures of study area springs corrected for gravitational potential energy dissipation (GPE)

Table 22. Mean annual surface temperatures at climate stations in the region for the period from 1961-1990 


\section{List of Figures}

Figure 1. Location of study area and large spring complexes along the eastern flank of the Cascade Range ..........................................................................................

Figure 2. Digital Ortho Photo of McKinney Butte area. Sisters city limits are shown in pink. Sampling sites are also shown. Indian Ford Creek flows south along the west side of McKinney Butte and Whychus Creek flows north along the east side. The McKinney Butte Springs are Frank and Chester springs. The Camp Polk Springs are Camp Polk Springhouse and Anderson Springs.

Figure 3. Additional sampling sites and tectonic structures. Sampling locations for springs (circles) and streams (squares) are shown. Precipitation data from the Three Creeks Meadow SNOTEL site (white cross) is presented in the Results Chapter. Fault locations (white lines), with the exception of the fault bounding the east side of McKinney Butte, are from Sherrod et al. (2004). The fault on the east side of McKinney Butte is from Wellik (2008). Faults are dashed where approximately located and dotted where concealed, ball and bar are on the downthrown side.

Figure 4. 1971-2000 average annual precipitation in the study area (cm/year) (data from Oregon Climate Service, 2008).

Figure 5. Study area geologic map. Modified from Lite and Gannett (2002).............25

Figure 6. Sisters USGS 7.5 minute quadrangle topographic map. Spring (triangles), stream (circles), and well (square) sampling sites are shown.

Figure 7. West facing view of Chester Springs. The springs discharge to the bottom of this pond at the base of McKinney Butte (shown in background). .30 
Figure 8. North facing view of Frank Springs outlet channel. The springs discharge from the base of McKinney Butte (not visible, but immediately to the right of the image). The confluence of the outflow channel and Whychus Creek is immediately below the visible area of the image.

Figure 9. Previous OWRD discharge measurement locations. 48

Figure 10. OWRD synoptic discharge measurement results along Whychus Creek between Three Sisters Diversion Canal and Henkle Butte

Figure 11. OWRD synoptic discharge measurement results along Indian Ford Creek between Camp Polk Rd. and the confluence with Whychus Creek.

Figure 12. Generalized lines of equal hydraulic head in the vicinity of the current study area (from Gannett and Lite, 2004). Contour intervals are 200 feet.......54

Figure 13. Seasonal discharge measurements along Whychus Creek between river miles 21.0 and 15.7. Measurement locations are shown on Figure 3...............58

Figure 14. Seasonal discharge measurements along Indian Ford Creek between river miles 2.1 and 0.8. The creek was dry at Camp Polk Rd. on 06/25/2007 and 09/21/2007 and at Barclay Dr. on all dates. 59

Figure 15. Measured discharge in Whychus Creek along Reach 1 (between Sisters and above Chester springs, see Figure 2 for measurement locations). Error bars are provided for each measurement. 60

Figure 16. Measured discharge along Reach 3 of Whychus Creek (below Frank springs to Camp Polk Rd). Error bars are provided for each measurement. ....61

Figure 17. Measured discharge along Reach 4 of Whychus Creek (Camp Polk Rd. to DRC gage). Error bars are provided for each measurement. 
Figure 18. Measured discharge in Whychus Creek along Reach 2 (above Chester springs to below Frank springs). Error bars are provided for each measurement.

Figure 19. Automated groundwater elevations recorded every 2 hours in the Lamb Well (DESC 54659). Data collection period ranged from 01/11/2007 to $10 / 31 / 2007$. Manual water levels were collected periodically between $11 / 15 / 2006$ and $03 / 06 / 2008$. 68

Figure 20. Automated groundwater elevations recorded every 15 minutes in the Lamb Well (DESC 54659). Data collection period ranged from 09/10/2007 to 10/31/2007. Manual water levels were collected periodically during this period.

Figure 21. Water level elevations recorded every 2 hours in the Lamb Well (DESC 54659) during July 2007. Water levels fluctuate diurnally by approximately 0.3 m. Maximum water level elevations occur between 16:00 and 20:00, and minimum elevations occur at 06:00. 70

Figure 22. Accumulated precipitation at Three Creeks Meadow SNOTEL site and water level elevations at the Lamb Well. Water levels in the well appear to rise during periods of higher precipitation. 71

Figure 23. Water level elevations in the Lamb Well (DESC 54659) and mean daily discharge at the OWRD Gage in Sisters. Water level and discharge trends are similar.

Figure 24. Locations of selected wells with long-term water level data. DESC 3016 is located west of McKinney Butte and DESC 2929 is located east 74

Figure 25. Long term water level records for two OWRD State Observation Wells in the vicinity of McKinney Butte. The Lamb Well is also shown. Water levels in 
both State Observation Wells have historically responded to decadal climate cycles. However, DESC 2929 has not responded to the most recent period of increased precipitation that began in 2006, while the water level in DESC 3016 has risen by about $3 \mathrm{~m}$.

Figure 26. Water level elevation contour map for the shallow part of the groundwater flow system in the study area. Well log-id and mean water level elevations are shown for wells used to generate the map. The elevations of springs that discharge shallow groundwater are also shown. Contour intervals are $15 \mathrm{~m}$. Faults (white lines) are dashed where approximately located and dotted where concealed, ball and bar are on the downthrown side. Fault locations are from Sherrod et al. (2004) and Wellik (2008). The groundwater level gradient on the east side of McKinney Butte is steeper than on the west side.

Figure 27. Water level elevation contour map for the deep part of the groundwater flow system in the study area. Well log-id and mean water level elevations are shown for wells used to generate the map. The elevations of springs that discharge regional groundwater are also shown. Contour intervals are $15 \mathrm{~m}$. Faults (white lines) are dashed where approximately located and dotted where concealed, ball and bar are on the downthrown side. Fault locations are from Sherrod et al. (2004) and Wellik (2008). The groundwater level gradient on the west side of McKinney Butte is extremely flat, while the gradient on the east side exceptionally steep. 78

Figure 28. Piper diagram for all spring and stream sampling locations. Water samples are classified on the basis of dominant cationic and anionic species. Most samples plot as mixed cation - bicarbonate waters, but several samples are magnesium - bicarbonate or sodium - bicarbonate waters. 86

Figure 29. Ionic concentrations for all samples. Samples from all sites on Whychus Creek above Chester Springs are included in the group "Whychus Creek above 
McKinney Butte Springs", samples from all sites on Whychus Creek below Frank Springs comprise the group "Whychus Creek below McKinney Butte Springs", and samples from all sites on Indian Ford Creek form the group

"Indian Ford Creek." 90

Figure 30. Average ionic concentrations for springs samples, $\mathrm{n}=\#$ of samples. Paulina Spring, Alder Springs, and Metolius Spring were only sampled once each, but are shown for comparison. .91

Figure 31. Plot of $\mathrm{Cl}$ vs $\mathrm{NO}_{3}$. Concentrations of both ions are elevated in Camp Polk Springhouse relative to other springs and streams, and the $\mathrm{NO}_{3}$ concentration in the Metolius Spring sample from the current study is much greater than in any other sample. The Metolius Spring sample from Evans et al. (2004) contained very little $\mathrm{NO}_{3}$ as did Paulina Spring samples. Several samples from Whychus and Indian Ford creeks did not contain measureable amounts of $\mathrm{NO}_{3}$.

Figure 32. Plot of $\mathrm{Cl}$ vs $\mathrm{SO}_{4}$. Concentrations of both ions are elevated in Camp Polk Springhouse relative to other sampled springs and streams. The McKinney Butte Springs and Anderson Springs plot near Metolius Spring, Alder Springs, and Lower Opal Springs. $\mathrm{Cl}$ and $\mathrm{SO}_{4}$ concentrations vary the most in Indian Ford Creek. Concentrations of both ions in Whychus Creek increase downstream of the McKinney Butte and Camp Polk Springs.

Figure 33. Plot of $\mathrm{Cl}$ vs Na. Samples from Camp Polk Springhouse (CPSH) display a $\mathrm{Cl}$ "shift" where $\mathrm{Na}$ concentrations in CPSH are similar to or slightly lower than concentrations in other sampled springs, but $\mathrm{Cl}$ concentrations are extremely elevated. Na concentrations in the McKinney Butte Springs are slightly higher than in Anderson Springs, are similar to the Na concentration in the Metolius Spring sample from the current study, are lower than concentrations in Alder Springs from the current and previous studies, and are 
lower than concentrations in Metolius Spring and Lower Opal Springs from other studies.

Figure 34. $\delta^{2} \mathrm{H}$ and $\delta^{18} \mathrm{O}$ delta values for all samples. Data from this study plot on a line given by $\delta^{2} \mathrm{H}=6.3 \delta^{18} \mathrm{O}-14.0$. The Global Meteoric Water Line (GMWL) defined as $\delta^{2} \mathrm{H}=8 \delta^{18} \mathrm{O}+10$ by Craig (1961) is also shown. 97

Figure 35. $\delta^{2} \mathrm{H}$ and $\delta^{18} \mathrm{O}$ delta values for samples from previous studies. Samples from the current study are shown for comparison. GMWL and LMWLs for each study are also shown. LMWL slopes are similar for all studies and are generally less than the GMWL slope, with the exception of Caldwell (1998), which has the same slope as the GMWL........................................................ 98

Figure 36. Temperature measurements in Whychus Creek and the McKinney Butte Springs from 08/30/2007 to 10/15/2007. Temperature in Whychus Creek generally follows local air temperatures. The constant temperature in the McKinney Butte Springs attenuates temperature fluctuations in Whychus Creek below the springs. 102

Figure 37. Water temperatures in the McKinney Butte Springs and the Lamb Well (DESC 54659) for the period from 08/30/2007 to 10/15/2007. Temperatures are stable in the springs, and are extremely stable in the well. The "angularity" of the temperature data for the McKinney Butte Springs is caused by resolution limitations $\left(0.15^{\circ} \mathrm{C}\right)$ of the temperature probe.

Figure 38. Measured and predicted temperature values at Whychus Creek below Frank springs. Blue and red series are predicted temperature values calculated from low $\left(0.10 \mathrm{~m}^{3} / \mathrm{s}\right)$ and high $\left(0.20 \mathrm{~m}^{3} / \mathrm{s}\right)$ estimates of discharge from the McKinney Butte Springs. Teal series $\left(0.185 \mathrm{~m}^{3} / \mathrm{s}\right)$ is the best fit (lowest SS) to the observed data. 112 
Figure 39. McKinney Butte Springs discharge estimated through the use of seepage runs on Whychus Creek, and temperature and electrical conductivity data collected in the McKinney Butte Springs and Whychus Creek. Error bars are provided for each method.

Figure 40. Mean monthly discharge in Whychus Creek from 1970 to 1990 measured at OWRD gaging station \#14075000 near Sisters, Oregon. Peak discharge typically occurred after spring snowmelt and was as much as ten times larger than low-flow conditions. 117

Figure 41. Daily and monthly mean discharge from January 2006 to April 2008 measured at OWRD gaging station \#14076050 in Sisters, Oregon. Peak monthly mean discharge occurred during June in 2006 and during November in 2007. Peak monthly discharge usually occurs during months of high precipitation; however, in 2007 peak discharge occurred in June as a result of late spring snowmelt

Figure 42. Estimated contribution (\% of total flow in Whychus Creek) from the McKinney Butte Springs to Whychus Creek. Values are shown as percent of mean daily (open circles) and mean monthly (solid circles, dashed lines) discharge in Whychus Creek. The blue, black, and red series use estimated spring discharges of $0.10,0.20$, and $0.30 \mathrm{~m}^{3} / \mathrm{s}$ respectively

Figure 43. Temperature measurements in Whychus Creek and the McKinney Butte Springs from 08/30/2007 to 10/15/2007. Temperature variations in Whychus Creek below the McKinney Butte Springs are attenuated by constant temperature discharge from the springs.

Figure 44. Relationship between $\delta^{18} \mathrm{O}$ in precipitation and elevation in the central Oregon Cascades (from James, 1999) 135 
Figure 45. Relationship between spring elevation and oxygen isotope composition.

The solid line shows the relationship between elevation and $\delta^{18} \mathrm{O}$ of precipitation as defined by snow core samples. The mean recharge elevation of the water can be estimated by tracing horizontal lines from the points representing spring samples to the elevations at which precipitation is comparable. The data used for the linear regression are from James (1999) and are shown in Figure 46 and are presented in Appendix C. 138

Figure 46. Relationship between elevation and water temperature in study area springs. The plus signs show the mean annual surface temperature at climate stations in the region and the dashed lines show the upper and lower bounds of the relationship between elevation and surface temperature (data from Oregon Climate Service). (a) Spring temperature as a function of discharge elevation. (b) Spring temperature as a function of the mean recharge elevation inferred from oxygen isotope content of the spring water. Spring temperatures in (b) are corrected for the expected $2.3^{\circ} \mathrm{C} / \mathrm{km}$ increase in water temperature as the water flows to lower elevations. The temperature difference $\Delta T$ indicates the amount of geothermal warming of the water. The Regional Springs (Lower Opal Springs, Alder Springs, and Metolius Spring) show a linear relationship between temperature and inferred recharge elevation.

Figure 47. Proposed conceptual model for groundwater flow through the study area. The faults bounding McKinney Butte not only juxtapose material of contrasting permeability, they also provide a preferential pathway to the surface for a small amount of deep groundwater flow. Much of the groundwater discharged at the McKinney Butte Springs has circulated deep in the flow system. 


\section{Chapter 1 - Introduction}

The Deschutes River is a major river draining $27,000 \mathrm{~km}^{2}$ of north-central Oregon (O'Connor et al., 2003) on the eastern, leeward side of the Oregon Cascade Range, a water-resource limited environment in which competitive demands for municipal, domestic, and irrigation water and adequate stream flows for aquatic habitats and recreation are severe. The Deschutes River on whole displays a remarkably consistent flow thanks to substantial input from large, regional spring systems (Gannett et al., 2003). However, local tributaries may be severely impacted by water diversions. Whychus Creek is one such stream that originates on the flanks of the Broken Top and Three Sisters volcanoes, flows northeast through the town of Sisters, and ultimately discharges into the Deschutes River (Figure 1). Although a significant tributary of the Deschutes River, a large percentage (historically, up to $100 \%$ ) of Whychus Creek's flow is diverted for irrigation 5 to $9 \mathrm{~km}$ upstream of Sisters (Gannett et al., 2001). Because Whychus Creek is severely impacted by irrigation withdrawals, spring discharge downstream from diversions becomes critical for maintaining streamflow and aquatic habitat.

One set of springs in particular, the McKinney Butte Springs (Frank Springs and Chester Springs on Figure 2), discharge to Whychus Creek approximately $10 \mathrm{~km}$ downstream from irrigation diversions. These springs may contribute a significant portion of total flow in Whychus Creek from Sisters to Alder Springs, $24 \mathrm{~km}$ downstream and provide important thermal refuge for anadromous fish during periods 
of severe thermal stress (Brown et al., 2007; Friedrichsen, 1996). McKinney Butte is bounded by the Tumalo fault (Sherrod et al., 2004; Wellik, 2008), part of the Sisters fault zone, a southern extension of the Green Ridge fault zone, which has been associated with discharge of regional groundwater to Metolius Spring (James, 1999; Gannett et al., 2001), the source of the Metolius River on the north side of Black Butte. Understanding how the McKinney Butte Springs fit into the larger hydrogeologic framework, specifically their overall impact on Whychus Creek flow and whether the springs originate from local or regional groundwater flow systems, is critical in evaluating their importance, long-term stability, and susceptibility to increasing groundwater withdrawals.

The objectives of this study are to: 1) quantify the magnitude and seasonal variation of flow from the McKinney Butte Springs; 2) quantify the relative contribution of the spring flow to the total flow of Whychus Creek on a seasonal basis; 3) determine the thermal impact of spring flow on Whychus Creek; 4) identify the source(s) of spring water via the hydrochemistry of the McKinney Butte Springs and local surface waters; and 5) develop a conceptual groundwater-flow model that accounts for the spatial and temporal distribution of discharge, hydraulic head, chemistry, and temperature within the geologic framework of the area. 


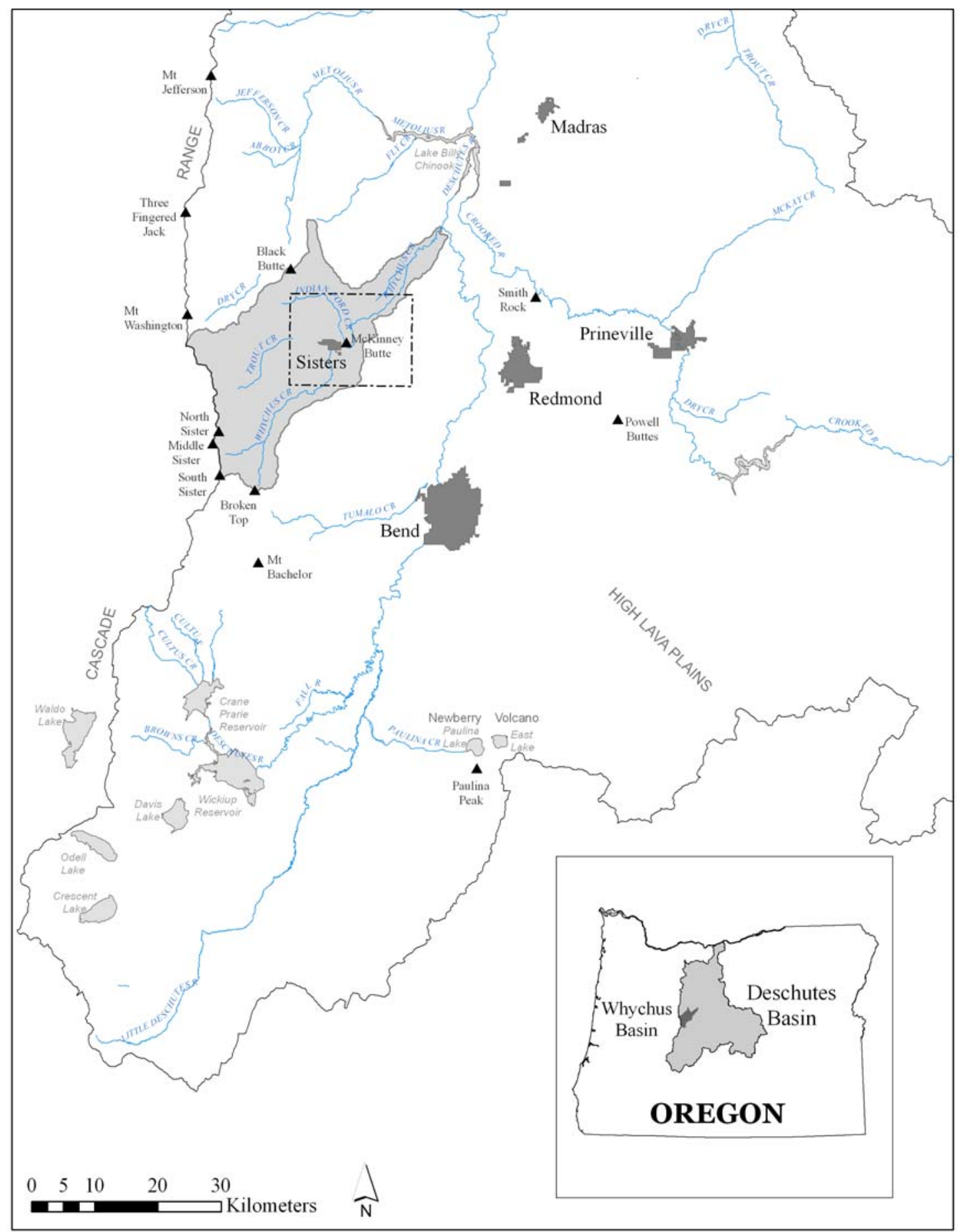

Figure 1. Location of study area and large spring complexes along the eastern flank of the Cascade Range. 


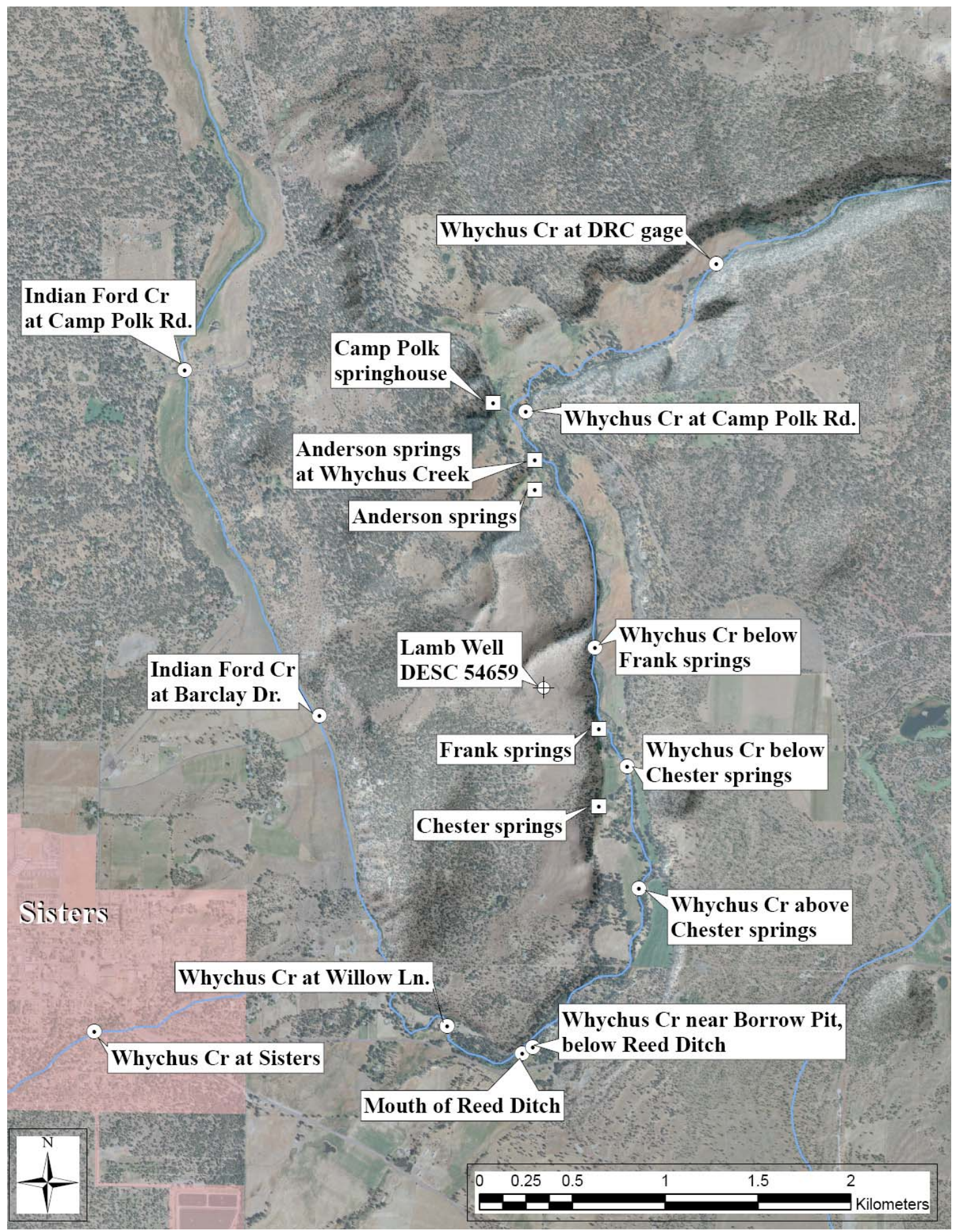

Figure 2. Digital Ortho Photo of McKinney Butte area. Sisters city limits are shown in pink. Sampling sites are also shown. Indian Ford Creek flows south along the west side of McKinney Butte and Whychus Creek flows north along the east side. The McKinney Butte Springs are Frank and Chester springs. The Camp Polk Springs are Camp Polk Springhouse and Anderson Springs. 


\section{Background}

\section{Location and Geography of Study Area}

The McKinney Butte study area encompasses approximately $275 \mathrm{~km}^{2}$ (square kilometers) in the Deschutes River drainage basin in central Oregon (Figure 1). Whychus Creek, which originates on the slopes of Broken Top and the Three Sisters volcanoes on the east side of the central Oregon Cascade Range, is the largest stream in the rapidly developing area around the town of Sisters. Indian Ford Creek flows south from its headwaters (Paulina Spring near Black Butte) along the west side of McKinney Butte until its confluence with Whychus Creek at the south end of the butte (Figure 3). Land surface elevations range from $1220 \mathrm{~m}$ (meters) above sea level in the southwest corner of the study area to $880 \mathrm{~m}$ in the northeast corner. The town of Sisters is the major population center in the study area. Principal industries include agriculture, forest products, tourism, and service industries.

Study area boundaries were positioned several kilometers from McKinney Butte to provide a larger area from which hydrologic and geologic data could be collected. The following sections comprise the study area: T14S/R09E sec. 13,14, 2326; T14S/R10E sec. 13-36; T14S/R11E sec 15-22, 27-34; T15S/R09E sec. 1,2, 11-14, 23-26; T15S/R10E sec. 1-30; T15S/R11E sec. 3-10, 15-22, 27-30. USGS 7.5 minute quadrangle topographic maps in the study area include Sisters, Henkle Butte, and parts of Three Creek Butte, Tumalo Dam, and Black Crater. 
The climate in the area is controlled by air masses that move eastward from the Pacific Ocean, across western Oregon and into central Oregon (Lite and Gannett, 2002). Orographic processes result in large amounts of precipitation in the Cascades Range (located less than $10 \mathrm{~km}$ west of the study area), with precipitation locally exceeding $508 \mathrm{~cm} / \mathrm{yr}$, mostly as snow during the winter (Taylor, 1993). Rates of precipitation diminish rapidly toward the east to less than $30 \mathrm{~cm} / \mathrm{yr}$ at the eastern margin of the study area (Figure 4). Temperatures also vary across the study area. Records from the Oregon Climate Service show that mean monthly minimum and maximum temperatures at Santiam Pass in the Cascade Range (period of record 1963 to 1985 ) range from -7 and $1{ }^{\circ} \mathrm{C}$ (degrees Celsius) in January to 6 and $23{ }^{\circ} \mathrm{C}$ in July (Oregon Climate Service, 2008). Temperatures are warmer at lower elevations within the study area. The mean monthly minimum and maximum temperatures in Sisters (period of record 1961 to 2007) range from -6 and $5{ }^{\circ} \mathrm{C}$ in January to 6 and $29^{\circ} \mathrm{C}$ in July (Oregon Climate Service, 2008).

\section{Significance of Study}

The origin of springs along McKinney Butte has been the subject of speculation by area water managers for many years (Lite, personal communication, 2011). A commonly held, yet unconfirmed view is that the springs receive water from losing reaches of Indian Ford Creek on the west side of the butte. While the source of the springs was unknown, their contribution to an over appropriated Whychus Creek has long been recognized. In 1994, springs along McKinney Butte provided the only 
flow to a $20 \mathrm{~km}$ reach of Whychus Creek below Indian Ford Creek and above Alder Springs (OWRD seepage run data in Gannett et al., 2001). Despite the fact that these springs at times provide a significant amount of the flow in Whychus Creek, very little is known about the physical and chemical characteristics of the water they discharge. This study examines the discharge rates and hydrochemistry of groundwater discharged at springs along McKinney Butte in an attempt to discern their source(s) and quantify their discharge and thermal contributions to Whychus Creek.

The thermal contribution of the McKinney Butte Springs may provide an important refuge for steelhead, red band trout, bull trout and Chinook salmon during periods of severe thermal stress (Friedrichsen, 1996; Brown et al., 2007). Recent relicensing of the Pelton and Round Butte dams on the Deschutes River allowed for the construction of a new fish passage, which will enable anadromous fish to migrate upstream to Whychus and other creeks in the upper Deschutes Basin that were historically important for fish rearing and spawning (Cramer and Beamesderfer, 2006). Thirty-four km of Whychus Creek (including the reach examined in this study) are on the Oregon Department of Environmental Quality (ODEQ) 303(d) list (identifies water bodies not meeting water quality standards) for exceeding the maximum allowable temperature for salmon rearing and spawning (ODEQ, 2007). If the McKinney Butte Springs discharge low temperature water, they could offer aquatic species thermal refuge during hot summer months.

Another important aspect of this study is the potential impact of recent development in the Sisters area on groundwater resources, including the springs along 
McKinney Butte. The degree to which a spring may be affected by groundwater withdrawals and contamination depends on the spatial scale of groundwater flow. A groundwater flow system can be divided into "local", "intermediate", and "regional" flow (e.g. Tóth, 1963). Local groundwater flow circulates to shallow depths and discharges close to the recharge area, while intermediate and regional groundwater flow generally circulate to much greater depths and discharge far from the inferred recharge area (Tóth, 1963). Intermediate- and regional-scale groundwater flow result in springs with little seasonal variation in discharge and temperature, while springs discharging local-scale groundwater often exhibit seasonal variations in both discharge and temperature. Additionally, springs discharging local-scale groundwater are more likely to be influenced by short-term variations in recharge and are more susceptible to contamination from shallow anthropogenic sources (e.g. septic systems and irrigation chemicals).

The scale of groundwater flow discharged at the springs has implications for the role of local geologic structures in the groundwater flow system. The springs along McKinney Butte occur at the westernmost edge of the Sisters fault zone, the southern extension of the Green Ridge fault zone (Sherrod et al., 2004). The Green Ridge fault (the major fault in the Green Ridge fault zone) marks the eastern boundary of the High Cascades axial graben (Allen, 1966; Priest, 1990) and is responsible for the tremendous amount of groundwater discharging to Metolius Spring at the headwaters of the Metolius River (Gannett et al., 2003). Chemical analysis suggests that the water discharged from Metolius Spring includes a large component of deep regional 
groundwater, implying vertical permeability along the Green Ridge escarpment (Gannett et al., 2003). Hydrochemical data collected from springs along McKinney Butte will provide new insights into the groundwater flow system in the vicinity of McKinney Butte and will help refine existing regional groundwater flow models. 


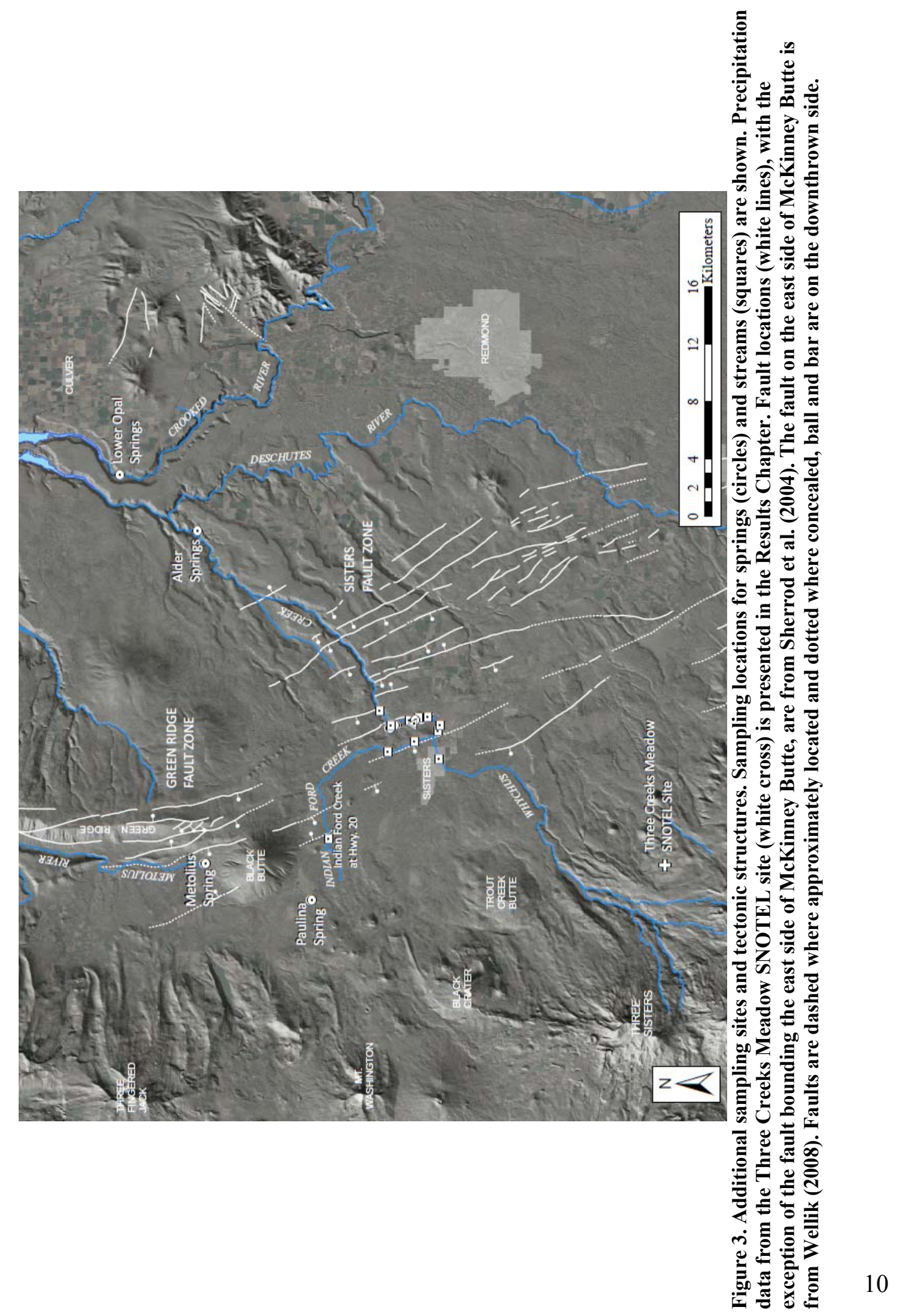




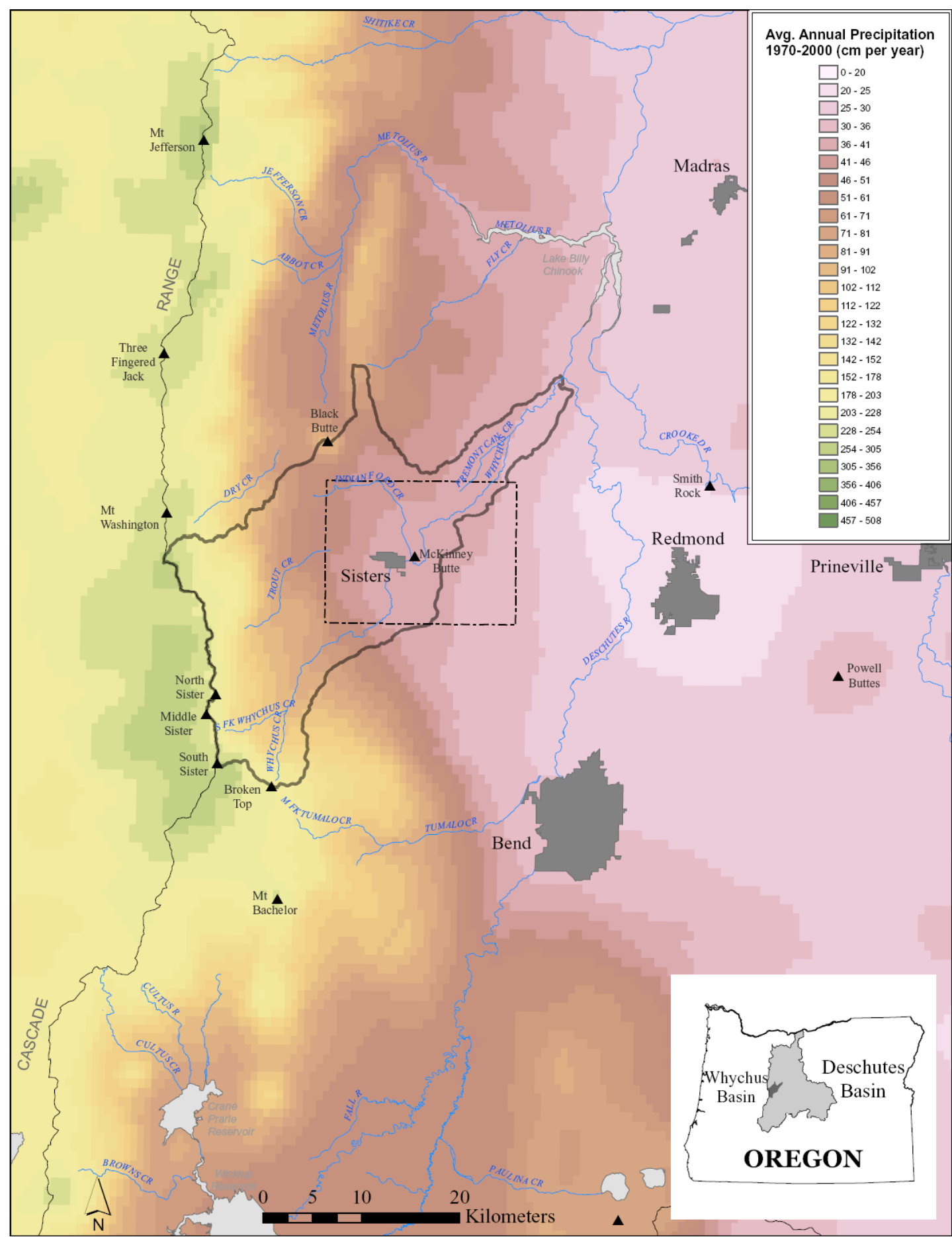

Figure 4. 1971-2000 average annual precipitation in the study area $(\mathrm{cm} / \mathrm{year})($ data from Oregon Climate Service, 2008). 


\section{Previous Work}

The hydrology and chemistry of surface and groundwaters in the central Oregon Cascades are reported by Russell (1905), Henshaw et al. (1914), Meinzer (1927), Ingebritsen et al. (1988, 1992, 1994), Manga (1996, 1997, 1998, 2001), James (1999), James et al. (1999, 2000), Evans et al. (2002, 2004), and Gannett et al. (2003). Several studies conducted by the United States Geological Survey (USGS) in cooperation with the Oregon Water Resources Department (OWRD) have examined the hydrogeology of the upper Deschutes Basin (Caldwell and Truini, 1997; Caldwell, 1998; Gannett et al., 2001; Lite and Gannett, 2002; Sherrod et al., 2002; Gannett and Lite, 2004). Additionally, OWRD has conducted synoptic measurements of discharge (also referred to as seepage runs) in Whychus and Indian Ford creeks. These studies provide the framework for my research. Of particular interest for the current study are the chemistry, hydrology, and isotopic variations in cold springs and streams as well as the impact of geology and geologic structures on groundwater flow.

James (1999) and James et al. (1999, 2000) examined the temperature and isotopes of $\mathrm{O}, \mathrm{H}, \mathrm{C}$, and noble gases of several large volume cold springs in the central Oregon Cascade Range. Hydrogen and oxygen isotope analyses were integrated with temperature measurements in an attempt to provide a conceptual model of groundwater flow for the region. Temperatures well above the average annual surface temperature of the inferred recharge elevation in several springs were attributed to 
geothermal warming. Additionally, the relationship between ${ }^{18} \mathrm{O}$ and elevation in local precipitation was used to estimate the recharge elevation of cold springs.

Manga (2001) examined the chemical and physical characteristics of several springs in the central Oregon Cascades. He used isotopic, chemical, and temperature data to determine the mean residence time of groundwater, infer the spatial pattern and extent of groundwater flow, estimate basin-scale hydraulic properties, calculate regional heat flow, and quantify the rate of magmatic intrusion beneath the volcanic arc.

Evans et al. $(2002,2004)$ examined the geochemistry and temperature of streams and springs in the Separation Creek drainage of the Three Sisters area. They attributed anomalously high chloride concentrations in Separation Creek to the input of thermal fluid.

The groundwater resources and hydrogeologic characteristics of the upper Deschutes basin have been reported in U.S. Geological Survey Water-Resources Investigations Reports and Open-File Reports (Caldwell and Truini, 1997; Caldwell, 1998; Gannett et al., 2001; Lite and Gannett, 2002; Gannett and Lite, 2004). These reports contain information concerning the hydrogeologic characteristics of specific hydrogeologic units (hydraulic conductivity, yield, specific capacity, coefficient of storage, and recharge), groundwater levels, hydrographs of water level fluctuations in specific wells, water chemistry, well log information from driller's reports, and water well and spring locations. 
OWRD staff conducted seepage runs on Whychus Creek in April 1994, August 2005, March 2006, and September 2006 and on Indian Ford Creek in February 1992 , March 2006, and September 2006. Measurement locations in Whychus Creek included the Sisters gage station and Camp Polk Road (Figure 2). Gains of $0.17 \mathrm{~m}^{3} / \mathrm{s}$ (April 1994), $0.06 \mathrm{~m}^{3} / \mathrm{s}$ (August 2005), $0.17 \mathrm{~m}^{3} / \mathrm{s}$ (March 2006), and $0.10 \mathrm{~m}^{3} / \mathrm{s}$ (September 2006) were measured along the reach between Sisters and Camp Polk Road. Indian Ford Creek discharge decreased from $0.19 \mathrm{~m}^{3} / \mathrm{s}$ at Camp Polk Road to $0.0 \mathrm{~m}^{3} / \mathrm{s}$ at Barclay Dr. in March 2006; the creek was dry at Camp Polk Road in February 1992 and September 2006. 


\section{Chapter 2 - Hydrogeologic Framework}

\section{Regional Setting}

Most of the upper Deschutes Basin lies within two major geologic provinces (Figure 1), the Cascade Range and the Basin and Range Province (Baldwin, 1981). The Cascade Range is a north-south trending zone of compositionally diverse volcanic centers with deposits extending from southern British Columbia to northern California (Baldwin, 1981; Sherrod and Smith, 2000). Although the Cascades Range primarily represents a constructional feature, growth of the range has been accompanied, in places, by the development of a north-south trending graben (Allen, 1966; Smith et al., 1987).

The central Oregon part of the Cascade Range is divided into two provinces, the Western Cascades and the High Cascade Range (Smith et al., 1987). The Western Cascades are composed of late Eocene to late Miocene tholeiitic and calc-alkaline basaltic lava flows, tephras, and basaltic to rhyolitic intrusions and are located west of the current Cascades crest (Smith et al., 1987; Ingebritsen et al., 1994). In central Oregon, the crest of the High Cascades is composed of coalesced basalt and basaltic andesite lava flows erupted by primarily early Pleistocene shield volcanoes and cinder cones (Smith et al., 1987).

The Basin and Range province is a region of crustal extension and is characterized by subparallel fault-bounded down-dropped basins separated by faultblock ranges. Individual basins and intervening ranges are typically 15 to $30 \mathrm{~km}$ 
across. The Basin and Range province covers much of the interior of the Western United States encompassing parts of Oregon, Nevada, Utah, California, Arizona and New Mexico (Baldwin, 1981). Extension and subsequent faulting in the Basin and Range province has been accompanied by widespread mafic volcanism (Draper, 1991; Camp and Ross, 2004).

\section{Stratigraphic Units and Hydrogeologic Characteristics}

\section{John Day Formation}

The John Day Formation is the oldest rock unit within the upper Deschutes basin. Rocks of this formation range in age from 20 to 40 million years. The John Day Formation is composed of several hundred meters of diagenetically altered volcanic and volcaniclastic sedimentary deposits (Robinson et al., 1984). Deposits of the John Day Formation thicken and coarsen from east to west and are similar in age to deposits associated with early Western Cascade volcanism. These factors led investigators to conclude that the John Day Formation is composed of distal deposits derived from vents in the Western Cascades (Waters, 1954; Peck, 1964; Robinson, 1975; Robinson et al., 1984). While Western Cascade volcanoes are probably the source of some John Day Formation deposits, recent work by the Oregon Department of Geology and Mineral Industries (e.g., McClaughry et al., 2009a, 2009b) have identified large Paleogene calderas located well east of previously postulated sources, suggesting a local origin for much of the John Day Formation. 
Devitrification (conversion of glass to clays and other minerals) of tuffaceous materials and weathering and secondary mineralization of lava flows has resulted in very low permeability in John Day Formation rocks (Gannett et al., 2001). As a result of the low permeability, groundwater does not easily transmit through the John Day Formation and the unit acts as a barrier to regional groundwater flow (Gannett et al., 2001). In the study area, the top of John Day age rocks occurs at an estimated elevation of approximately $300 \mathrm{~m}$ (cross section B, plate 1, Lite and Gannett, 2002).

\section{Deschutes Formation}

The Deschutes Formation represents an assemblage of lava flows, ignimbrites, and volcanogenic sediments, primarily from Cascade volcanism occurring between 7 and 4 Ma (Smith et al., 1987). The thickest exposure of Deschutes Formation material is along Green Ridge, located in the western part of the basin, where over $700 \mathrm{~m}$ of mostly lava flows are visible (Smith, 1986). The formation thins to the east to $250 \mathrm{~m}$ along the Deschutes River where mostly volcaniclastic sediments, ignimbrites, and lava flows are exposed, and to the northeast near Madras where the formation is less than $75 \mathrm{~m}$ in thickness, and is dominated by material derived from eroded John Day Formation domes, lava flows, and ignimbrites (Smith, 1986). According to Smith et al. (1987), Deschutes Formation units were also likely derived from the site of the present-day Cascade Range. Around 5.4 Ma, the tectonic regime shifted from compressional to extensional and the early High Cascades subsided into an extensional 
basin (Smith, 1991). The western escarpment of Green Ridge was formed by one of the faults bounding the basin (Smith et al., 1987).

Deschutes Formation deposits are the major groundwater-bearing units in the upper Deschutes basin (Lite and Gannett, 2002). The permeability of the Deschutes Formation ranges from relatively low in fine-grained sedimentary deposits, dense lava flows, and pyroclastic flows, to high in coarse-grained unconsolidated sediments and vesicular and brecciated lava flows (Lite and Gannett, 2002). East of the Tumalo fault, the deposits occur at land surface or at shallow depth in the subsurface.

\section{Cascade Range Volcanics}

Several hundred meters of down-to-the-west displacement confined Pliocene to Holocene volcanic deposits to an intra-arc graben (Smith et al., 1987). Volcanic activity in the High Cascades since the late Pliocene (about $3 \mathrm{Ma}$ ) has subsequently buried volcanic centers that produced the Deschutes Formation. The present day High Cascades Range in central Oregon is composed of coalesced basalt and basaltic andesite shield volcanoes and cinder cones that are locally overlain by larger glaciated late Pleistocene to Quaternary stratovolcanoes (Hughes and Taylor, 1986; Hildreth, 2007).

Cascade Range volcanic deposits are highly permeable at shallow depths. The near-surface deposits are often highly fractured or otherwise porous and generally lack secondary mineralization (Gannett et al., 2001). The Cascade Range is the major recharge area for the upper Deschutes basin and these deposits provide the primary 
pathway for groundwater movement from the recharge area to the basin (Gannett et al., 2001, 2003; Ingebritsen et al., 1992, James et al., 2000; Lite and Gannett, 2002; Manga, 1996, 1997, 1998). Cascade Range volcanics are an important source of groundwater west of the Tumalo fault.

\section{Quaternary Glacial Outwash}

Several Quaternary-age sedimentary deposits are found within the upper Deschutes Basin (Lite and Gannett, 2002). Two major periods of glaciation during Pleistocene time left deposits in the upper Deschutes Basin, the older Jack Creek and the younger Cabot Creek (Sherrod and Smith, 2000). The Cabot Creek glaciation is divided into Suttle Lake and Canyon Creek advances (Sherrod and Smith, 2000). Deposits of Jack Creek are limited to an area east of Three Fingered Jack. Easterbrook (1986) correlated Jack Creek glaciation to Hayden Creek glaciation in Washington, which is thought to be 140,000 years in age. The Suttle Lake advance was the last major glacial advance in central Oregon, occurring about 25,000 years ago (Sherrod and Smith, 2000). Outwash of the Suttle Lake advance covers much of the Metolius River valley and is up to 40-m thick in the vicinity of Sisters (Sherrod and Smith, 2000; Lite and Gannett, 2002). Holocene deposits were formed by mass wasting of upland deposits, deposition of alluvium by both low- and high-energy streams, and deposition into lakes. These deposits can be locally up to 60 meters thick (Lite and Gannett, 2002). 
Glacial outwash and intercalated High Cascades lavas deposited on the west side of the Tumalo fault form the principal aquifer in the town of Sisters (Lite and Gannett, 2002). Well reports for wells penetrating the outwash indicate it is comprised mostly of sand and gravel. These unconsolidated coarse-grained sediments and lavas have very high permeability. Hydraulic conductivity estimates are on the order of 50 m/d (Gannett et al., 2001).

\section{Tectonic Structures}

The fault zone in the area between Bend and Sisters has been previously referred to as the Tumalo fault zone (Priest, 1990) and the Sisters fault zone (Sherrod et al., 2004). Wellik (2008) referred to the western part of the fault zone as the Tumalo fault zone, and the eastern part as the Sisters fault zone. The current study follows the nomenclature of Sherrod et al. (2004); faults around the city of Sisters are referred to as the Sisters fault zone, and faults in the vicinity of Green Ridge are part of the Green Ridge fault zone (Figure 3).

The Sisters fault zone trends north-northwest from Newberry Volcano to Black Butte (Lite and Gannett, 2002). The sense of movement along the most prominent fault, (the Tumalo fault) which extends through the study area along the west side of McKinney Butte, is down-to-the-west (Taylor, in preparation, fide Sherrod et al., 2004). Other faults exhibit down-to-the-east or down-to-the-west displacement. As much as 55 to $60 \mathrm{~m}$ of dip separation along the Tumalo fault has occurred near upper Tumalo Reservoir (10 km south of the study area) (Lite and Gannett, 2002). The 
westernmost fault strands of the Sisters fault zone that exhibit down-to-the-west displacement (particularly the Tumalo fault) were partial barriers to streams flowing eastward from the Cascade Range and, thus, formed depositional centers for Pleistocene volcanic and glacial outwash deposits (Lite and Gannett, 2002). The Tumalo fault escarpment along the west side of McKinney Butte has provided a depositional center for up to $40 \mathrm{~m}$ of glacial outwash in the Sisters area (Lite and Gannett, 2002).

The escarpment of Green Ridge represents the east margin of an intra-arc graben within the Cascade Range (Taylor, 1981, Smith et al., 1987). The Green Ridge fault zone is comprised of many parallel north-south normal faults with down-to-thewest net displacement in excess of $600 \mathrm{~m}$ (Conrey, 1985). Displacement on the Green Ridge fault zone took place during late Miocene and early Pliocene (Conrey, 1985).

\section{Geologic Controls on the Occurrence of Springs}

Much of the groundwater discharge in the upper Deschutes Basin occurs as springs in two principal settings: 1) near the confluence of the Deschutes and Crooked Rivers; and 2) in and adjacent to the Cascade Range (Gannett et al., 2003). The distribution and rates of groundwater discharge in these settings is controlled by complex structural and stratigraphic interactions.

Groundwater discharge near the confluence of the Deschutes and Crooked Rivers is the result of deep incision by the rivers (Gannett et al., 2003). Locally, the Deschutes and Crooked Rivers have incised canyons exposing much of the Deschutes 
Formation section, intercepting the regional groundwater surface and resulting in large spring complexes in the canyon walls (Gannett et al., 2003). Additionally, approximately 15 kilometers north of the confluence area, near Pelton Dam the Deschutes River has cut entirely through the highly permeable Deschutes Formation to the much less permeable John Day Formation, diverting all groundwater flow to the surface (Gannett et al., 2003). Lower Opal Springs, found in the canyon wall of the Crooked River, discharges groundwater that contains geothermal heat and magmatic gasses, both indications of deep regional-scale groundwater flow (James, 1999). Groundwater discharged at Lower Opal Springs has travelled over $50 \mathrm{~km}$ in the subsurface.

Large spring systems such as the headwaters of Brown's Creek and the Quinn and Cultus Rivers are found on the east flanks of the central Oregon Cascade Range (Figure 1). These springs issue from the edges or ends of highly permeable Quaternary lava flows at the contact with less permeable fine-grained sediments that have filled the Shukash structural basin (Gannett et al., 2003). Groundwater discharged from the springs has followed shallow local-scale groundwater flow paths (Manga, 1998; James et al., 2000; Gannett et al., 2003).

Large-volume springs such as Spring River and Metolius Spring are found at the eastern margin of the Cascade Range (Gannett et al., 2003). Spring River is located at the western edge of the Shukash structural basin in the southern part of the upper Deschutes Basin. Metolius Spring, the headwaters of the Metolius River, occurs along the Green Ridge fault, which marks the eastern edge of the High Cascades graben 
(Allen, 1966; Priest, 1990). Vertical movement along the Green Ridge fault system is estimated to be over $600 \mathrm{~m}$ (Conrey, 1985). According to Gannett et al. (2001), the impediment to eastward groundwater flow at the base of Green Ridge could be due to a low- permeability gouge zone along the fault planes or the juxtaposition of permeable strata on the west side of the fault system against low-permeability material on the east. Groundwater discharged at Metolius Spring contains geothermal heat and magmatically derived carbon and helium-3 (James, 1999). The presence of elevated temperature and magmatic gasses indicates that Metolius Spring discharges water that has circulated deep in the groundwater flow system and suggests there is vertical permeability along the Green Ridge escarpment (Gannett et al., 2003).

\section{Study Area Geology}

Geologic maps of the majority of the study area have been generated by Oregon State University Emeritus Professor Dr. Ed Taylor. His maps of the Sisters (Taylor, in preparation), Henkle Butte (Taylor, 1998), Tumalo Dam (Taylor and Ferns, 1994) and Three Creek Butte (Taylor and Ferns, 1995) 7.5 minute quadrangles have been incorporated into a geologic compilation map of the Bend 30-x 60-minute quadrangle (Sherrod et al., 2004). Lite and Gannett (2002) included a generalized version of the map later published by Sherrod et al., (2004). In this study, I present an ArcGIS coverage of the study area based on the geologic map generated by Lite and Gannett (2002) (Figure 5). 
The oldest rocks exposed in the study area are basalt flows, sedimentary deposits, and pyroclastic flows of the Deschutes Formation (Tb, Ts, and Tp in Figure 5). These rocks are present mostly east of the Sisters fault zone, although a few isolated dome remnants and cinder cones are found west of McKinney Butte. Deschutes Formation sedimentary deposits (Ts) underlie Deschutes Formation basalt flows $(\mathrm{Tb})$ in the study area, and are only exposed where modern drainages have incised through the basalt. A Deschutes Formation partially to moderately welded pyroclastic flow deposit (Tp) is exposed along, and underlies, the east side of McKinney Butte (Taylor, written communication, February 6, 2008).

McKinney Butte is composed of late Pliocene high-Fe andesite lavas erupted from cinder cones on the ridge crest (Taylor, written communication, February 6 , 2008). Lava on the north side of the butte has an age of $3.3 \pm 0.2 \mathrm{Ma}$ (K-Ar, whole rock; Armstrong et al., 1975).

The west margin of the Sisters fault zone generally marks the basinward limit of Quaternary Cascade Range deposits in the study area. However, several basalt flows $(\mathrm{Qb})$ have erupted from vents located east of the Tumalo fault (e.g. Henkle Butte). Glacial outwash of the Suttle Lake advance (Qs) has been deposited in the Sisters area west of the Tumalo fault. Quaternary sedimentary deposits exposed east of the fault are generally of late Pleistocene age and are thought to be products of glacial outburst floods originating in the Cascades (Sherrod et al., 2004). 


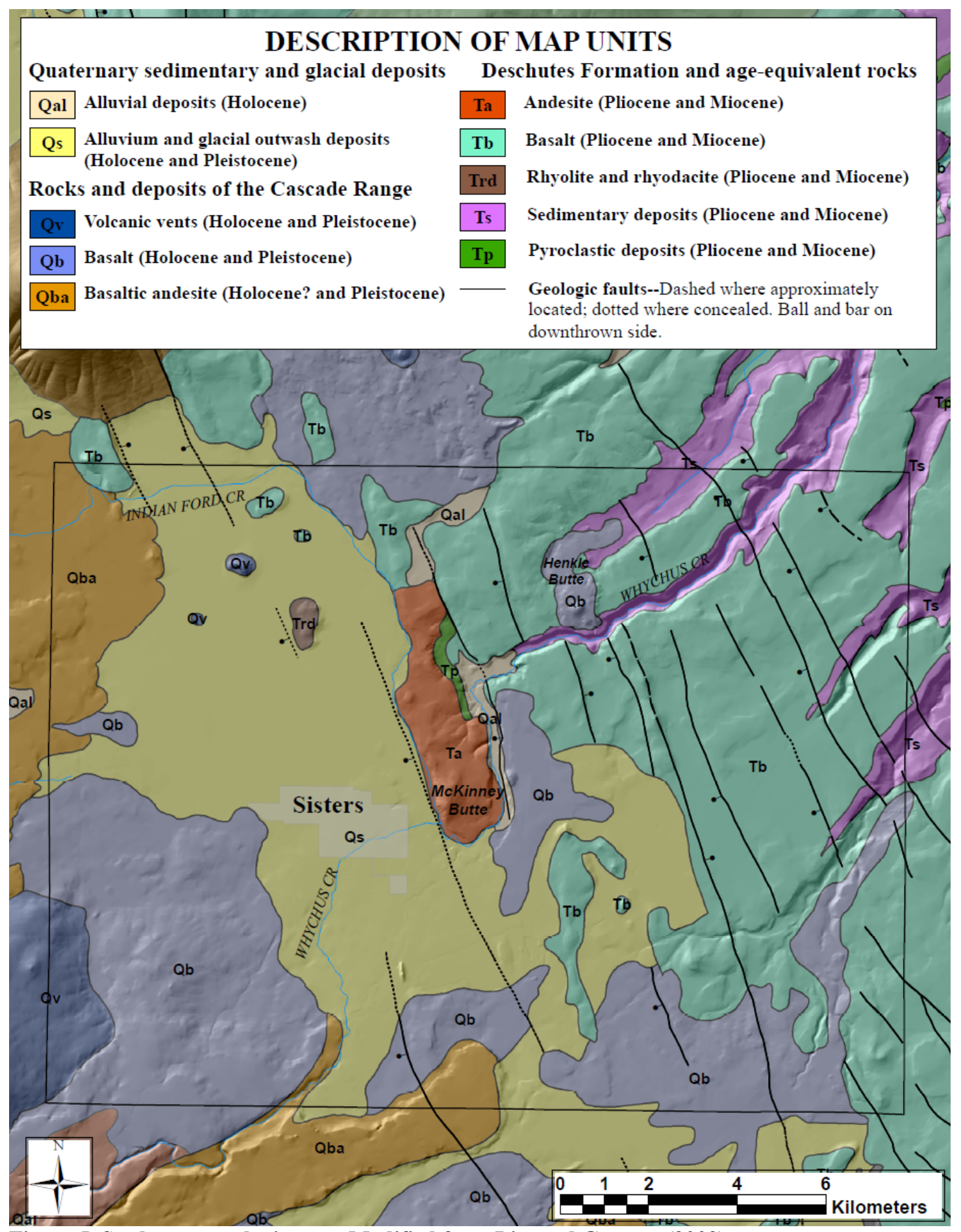

Figure 5. Study area geologic map. Modified from Lite and Gannett (2002). 


\section{Chapter 3 - Study Design and Methods}

\section{Study Design}

This section describes the naming system used in identifying sites visited during this study and previous studies and gives a brief background of the McKinney Butte area and local springs. The rationale behind the selection of this study's sample sites is also provided.

\section{Well, Spring, and Stream Data}

Six springs and a total of twelve stream locations, nine along Whychus Creek and three along Indian Ford Creek were sampled during this study (see Figures 2 and 3 for site locations). Additionally, hydrologic and geologic data (from previous studies) from 111 wells, 44 springs, 39 snow core sites, and 7 surface water sites were examined.

Sampling sites visited during this study were assigned names unless they had been named during previous studies or were named on a USGS topographic map. Previously unnamed surface water sites on Whychus and Indian Ford creeks were assigned names according to location (e.g., Indian Ford Creek at Barclay Dr., Whychus Creek at Sisters gage). Five of the seven springs visited during this study were identified on USGS topographic maps. Of these, three were named in prior studies (Metolious Spring, Paulina Spring, and Alder Springs). The two unnamed springs that were identified on USGS topographic maps were assigned names based 
on property ownership (Anderson Springs) or location (Camp Polk Springhouse). The two springs that were not identified on USGS topographic maps were assigned names based on property ownership (Frank Springs and Chester Springs). The well visited during this study was also named according to property ownership and OWRD well log-id (Lamb well, DESC 54659).

Wells not visited during this study are identified by their OWRD well log-id. The OWRD well log-id is a combination of a four-letter county code and a well-log number with up to 6 digits (e.g. DESC 1294) which uniquely identifies each water well report in Ground Water Resource Information Distribution (GRID), a statewide computer database maintained by OWRD.

\section{Sample Site Background}

OWRD seepage runs in 1994, 2005, and 2006 indicated Whychus Creek was gaining streamflow between the Sisters Gage station and Camp Polk Rd. (see Previous Work section; site locations on Figure 2). The bulk of the increased flow had been attributed to springs in the vicinity of Camp Polk Rd. (Anderson Springs and Camp Polk Springhouse, Figure 6), but never verified (throughout this paper, Anderson Springs and Camp Polk Springhouse will also be referred to as the Camp Polk Springs when the topic applies to both springs). Visual inspection of these springs in September 2006 suggested it was unlikely they were supplying the majority of the gain in streamflow to Whychus Creek; their combined discharge was estimated to be

much less than the $0.06-0.17 \mathrm{~m}^{3} / \mathrm{s}$ gain measured along this reach. Consequently, the 
reach of Whychus Creek on the east side of McKinney Butte was searched for other possible sources. Frank Springs and Chester Springs were observed approximately 2.0 and $2.5 \mathrm{~km}$ upstream from Camp Polk Rd. These springs (specifically Frank Springs) appeared to be discharging a much greater volume of water than the Camp Polk Springs (Frank Springs and Chester Springs will be referred to as the McKinney Butte Springs when the subject matter applies to both).

The morphologies of Frank and Chester Springs are considerably different. Chester Springs is a point source that surfaces in the bottom of a pond located approximately $70 \mathrm{~m}$ west of Whychus Creek (Figure 7). The pond is connected to Whychus Creek via a narrow channel extending from its east side to the creek. Conversely, Frank Springs materializes from the base of McKinney Butte, not at a single point, but along an approximately 25 - to $50-\mathrm{m}$ linear section. Near the end of this section, Frank Springs discharges via a short $(<10 \mathrm{~m})$ channel into the creek (Figure 8). Although the morphologies of Frank and Chester Springs are quite different, the physical characteristics of their outflow channels are surprisingly similar. Both springs have shallow and narrow outflow channels. These traits precluded direct measurement of their discharge. It is also likely that some groundwater bypasses the springs outflow channels and discharges directly to Whychus Creek.

\section{Sample Site Selection}

Sample sites were selected to address the following questions: 1) What is the magnitude and seasonal variation of flow from the McKinney Butte Springs? 2) What 
is the relative contribution of the springs to the total flow of Whychus Creek on a seasonal basis? 3) What is the thermal impact of spring flow on Whychus Creek? and 4) What is the source(s) of the McKinney Butte Springs? Additionally, sites were selected to assist in developing a local conceptual groundwater flow model.

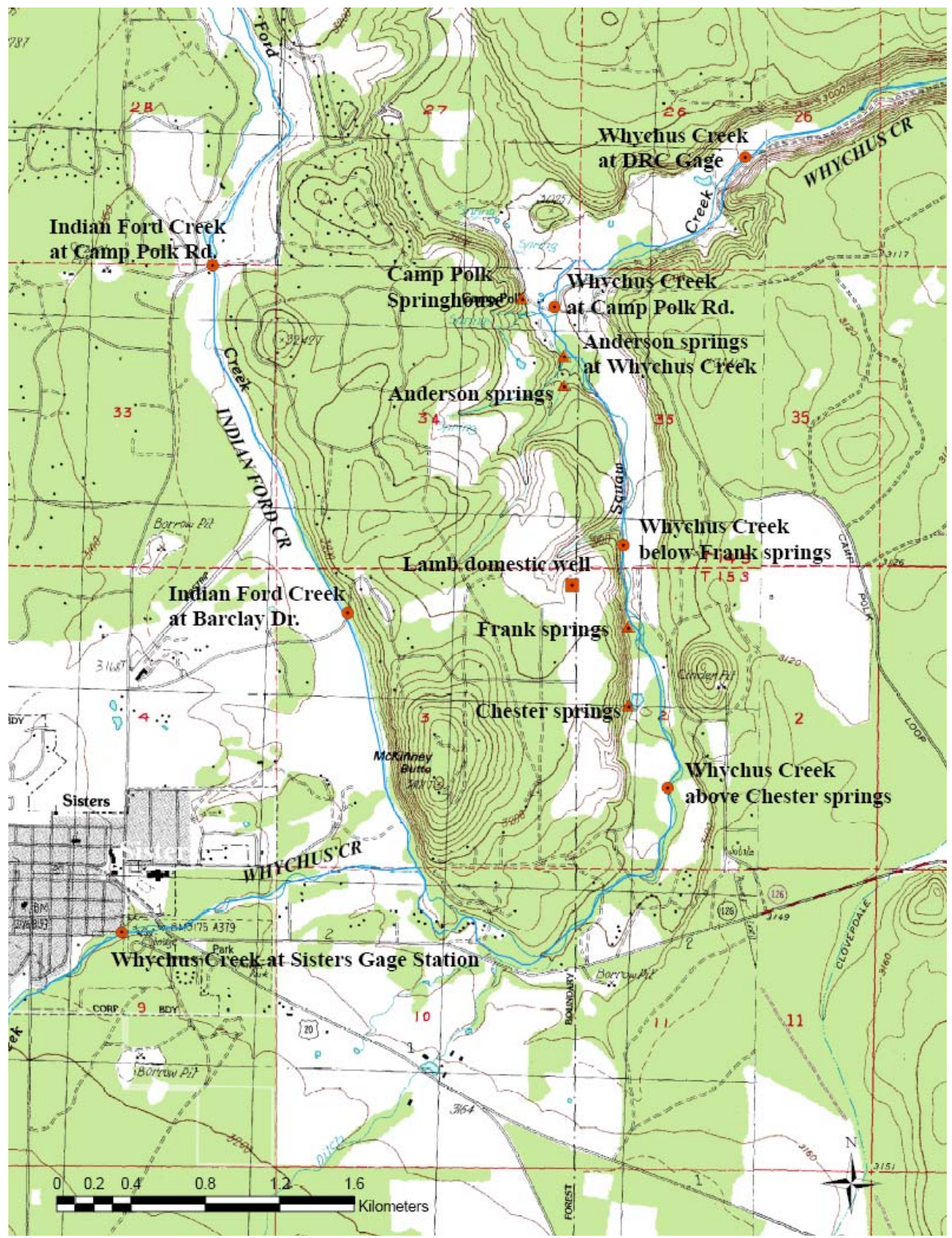

Figure 6. Sisters USGS 7.5 minute quadrangle topographic map. Spring (triangles), stream (circles), and well (square) sampling sites are shown. 
Given the geologic framework of the study area, initial plausible sources for the McKinney Butte Springs included: 1) the reappearance of Whychus Creek and or Indian Ford Creek surface water that was intermittently lost to high-permeability gravel deposits up gradient from the springs; 2) preferential movement of shallow groundwater through McKinney Butte ( west to east) via faults or fractures; 3) deep regional groundwater flow that is migrating through faults bounding the west side of McKinney Butte; 4) return water from irrigation uses; or 5) seasonal precipitation on McKinney Butte.

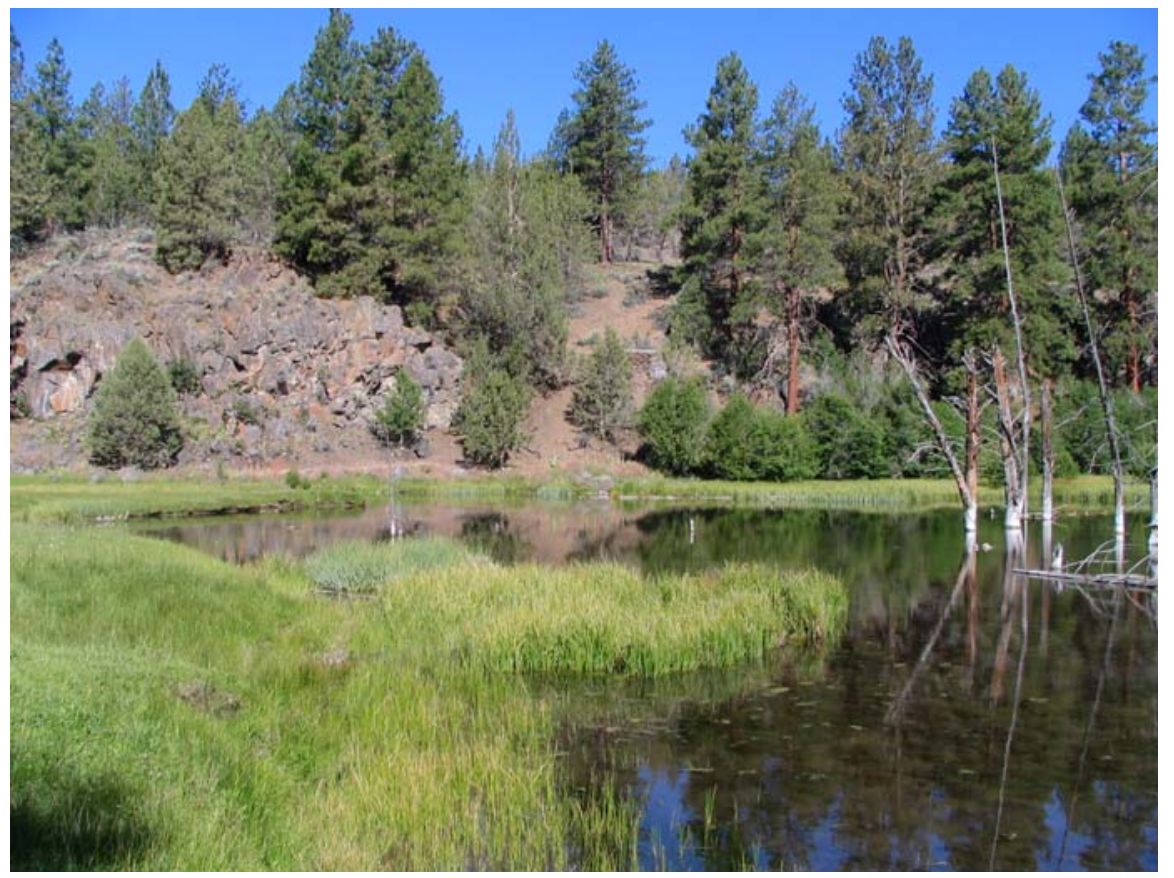

Figure 7. West facing view of Chester Springs. The springs discharge to the bottom of this pond at the base of McKinney Butte (shown in background).

The magnitude and seasonal variation of flow from the McKinney Butte Springs (question 1) and their relative contribution to Whychus Creek (question 2) were examined via seepage runs on Whychus Creek and simple mixing models that compared temperature, and electrical conductivity in Whychus Creek and the springs. 
The morphology of the McKinney Butte Springs outflow channels precluded direct measurement of discharge; consequently, spring discharge was calculated from the difference in Whychus Creek discharge directly upstream (Whychus Creek above Chester Springs) and downstream (Whychus Creek below Frank Springs) from the springs. Likewise, mixing models using temperature and electrical conductivity data collected at the same locations on Whychus Creek and at the McKinney Butte Springs were also used to estimate discharge from the McKinney Butte Springs. In the mixing models, temperature and conductivity data were considered a proxy for discharge where a change of some amount in discharge is proportional to a change in temperature or conductivity. Discharge was also measured on one occasion at Whychus Creek below Chester Springs to determine the individual discharges of Chester Springs and Frank Springs. The Whychus Creek at Sisters gage site was used to examine the change in discharge between Sisters and the McKinney Butte springs. Sites below the McKinney Butte springs were used to examine the discharge of the Camp Polk Springs (Whychus Creek at Camp Polk Rd.) and to examine the change in discharge from McKinney Butte to Camp Polk meadow (Whychus Creek at DRC gage). Seepage runs were conducted in Indian Ford Creek to quantify the flow in the creek and the amount of seepage occurring along the west side of McKinney Butte. Temperature data collected at the McKinney Butte springs and at locations on Whychus Creek above and below the springs was used to assess the thermal impact of the springs on Whychus Creek (question 3). Additional sites on Whychus Creek 
(Sisters gage, Camp Polk Rd., and DRC gage) were monitored to examine thermal conditions at locations distant from the springs.

Chemical and isotopic data were used to identify the source(s) of the McKinney Butte Springs. The chemical and isotopic concentrations of the McKinney Butte Springs were compared to other area springs (Paulina Spring, Metolius Spring, and Alder Springs) to establish a source area for the springs. Alder Springs and the Metolius Spring are thought to discharge mostly regional-scale groundwater, while Paulina Spring is recharged locally (Caldwell, 1998; James, 1999). Additionally, data from the Camp Polk Springs was examined to determine their source. Whychus and Indian Ford creeks were also compared with the McKinney Butte Springs to determine if they were the source of the springs.

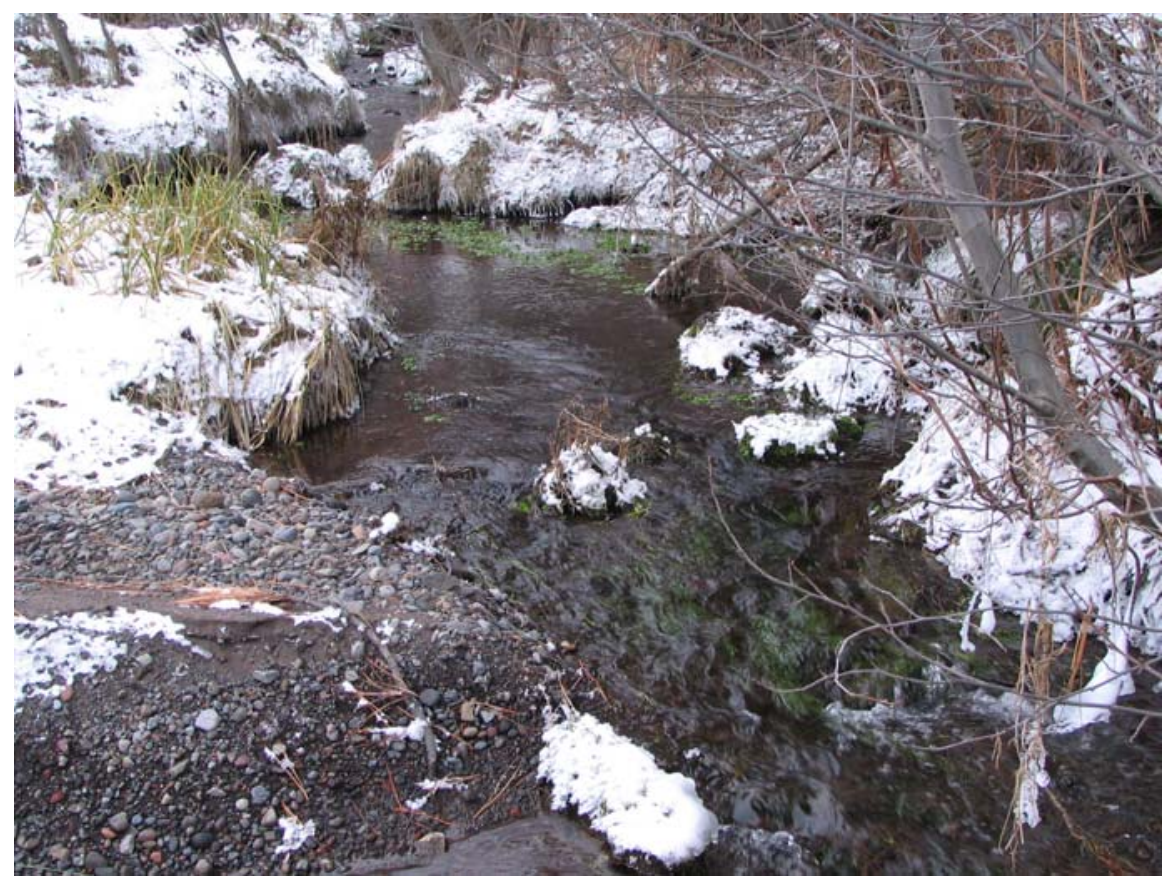

Figure 8. North facing view of Frank Springs outlet channel. The springs discharge from the base of McKinney Butte (not visible, but immediately to the right of the image). The confluence of the outflow channel and Whychus Creek is immediately below the visible area of the image. 


\section{Methods}

\section{Discharge Measurements}

Surface-water discharge measurements were made on a seasonal basis between April 2007 and January 2008 (measurement locations shown on Figure 2).

Groundwater flow to or from streams was estimated using sets of streamflow measurements known as seepage runs. A seepage run consists of a series of streamflow measurements taken a few hundred feet to several miles apart along a stream over a short enough period that temporal variations in streamflow are minimal (Gannett et al., 2001). Tributary inflow and diversions are measured as well. Any temporal changes in streamflow occurring during the measurement period are also measured or otherwise accounted for.

Sources of errors and uncertainties in determining stream discharge via seepage runs include 1) random errors related to the method of measurement (e.g. errors in the measurement of stream channel dimensions), 2) systematic errors caused by improperly calibrated equipment and other factors, and 3) variation in streamflow during the seepage run. These errors are discussed in Appendix A. The total uncertainty for each measurement site and for calculated spring discharge is presented in the Results section of Chapter 4. 


\section{Spring- and Surface-water Sampling}

Spring- and surface-water samples were collected from locations identified in the McKinney Butte area between September 2006 and January 2008 (sampling locations shown on Figure 2). Additional samples were collected from Paulina Spring, Indian Ford Creek at Hwy 20, and Metolius Spring, near Black Butte; and Alder Springs, near the confluence of Whychus Creek and the Deschutes River (sampling locations shown on Figure 3). The reader is referred to the Sample Site Selection section in this chapter for explanations behind the selection of sampling sites. The samples were filtered at each location using dedicated $0.45-\mu \mathrm{m}$ nylon membrane syringe filters. Cation samples were acidified using $2 \%$ by volume nitric acid. All samples were stored in polyethylene bottles and placed in an ice chest in the field and were immediately refrigerated upon return to the lab. One field-equipment blank was collected during each sampling campaign as a check for potential contamination.

Specific electrical conductance, $\mathrm{pH}$, and temperature measurements were made in the field using a YSI 556 MPS multi-meter with appropriate probes. The YSI meter was calibrated in the field the day of sampling to ensure accurate and consistent measurements. Calibration procedures are outlined in Table 1.

Table 1. Calibration standard and procedures.

\begin{tabular}{ccc}
\hline Parameter & Standard & Method \\
\hline $\mathrm{pH}$ & $4,7,10$ & 3 point calibration \\
Specific & & \\
Conductance & $147.0,1407(\mu \mathrm{S} / \mathrm{cm})$ & calibration in lab and field check \\
Temperature & na & no calibration \\
\hline
\end{tabular}




\section{Cation, Anion, and Silica Analysis}

Anion concentrations were determined with a Dionex Model 2500 ion chromatograph equipped with an IonPac AS14A column and using an 8.0-mM carbonate-1.0-mM bicarbonate eluent at a pumping rate of $1.0 \mathrm{ml} \mathrm{min}{ }^{-1}$. Typically, four external standards prepared from commercial stock solutions were used to calibrate the instrument prior to each sample batch. Quality control samples laboratory blanks and check standards - were analyzed prior to analyzing samples and repeated after every 10 samples to monitor accuracy and precision.

Alkalinity as $\mathrm{HCO}_{3}$ was determined in the lab using the Gran Plot Method. Samples were titrated to $\mathrm{pH}<4.0$ with a $0.009741 \mathrm{~N}$ solution of $\mathrm{Na}_{2} \mathrm{CO}_{3}$ in $\mathrm{HCl}$. The amount of titrant added to reach the inflection point was determined by extrapolating the straight-line portion of the curve of $\mathrm{pH}$ versus Gran Function.

Major cation concentrations were measured with a Perkin Elmer AAnalyst 300 atomic absorption spectrometer. All cations were analyzed using an air-acetylene flame with the wavelengths and slit widths presented in Table 2 (Perkin Elmer, 1994). Instrument calibration was performed using three external standards, prepared by dilution from commercially available standard solutions, prior to each analytical run. Dilutions were made when initial sample concentrations were significantly $(>10 \%)$ greater than the highest standard. A discussion of analytical error for anion, cation, and silica analysis is presented in Appendix B.

Silica analysis was performed on a Beckman Coulter DU 730 ultraviolet visible spectrophotometer (UV-Vis) using the molybdate yellow method. Silica 
concentrations were determined from a calibration curve created from seven standards of known concentration. All samples were diluted to bring silica concentrations under the highest standard (10 ppm).

Table 2. Atomic Absorption parameters used for cation analysis.

\begin{tabular}{lcccc}
\hline \multicolumn{1}{c}{ Ion } & Optimal Range (ppm) & Wavelength (nm) & Slit Width (mm) & Fuel Mix \\
\hline $\mathrm{Ca}^{2+}$ & $0.2-20$ & 422.7 & 0.70 & air-acetylene \\
$\mathrm{K}^{+}$ & $0.1-2$ & 766.5 & 0.70 & air-acetylene \\
$\mathrm{Na}^{+}$ & $0.03-1$ & 589 & 0.20 & air-acetylene \\
$\mathrm{Mg}^{2+}$ & $0.02-2$ & 285.2 & 0.70 & air-acetylene \\
\hline
\end{tabular}

\section{Isotope Analysis}

Isotopic samples collected in September 2006 and April 2007 were sent to Geochron Laboratories in Cambridge, Massachusetts and samples collected in June, August, and September 2007 and January 2008 were sent to the Colorado Plateau Isotope Laboratory (CPIL) at Northern Arizona University for stable oxygen and hydrogen isotope analysis. Isotopic sample preparation was by the water- $\mathrm{CO}_{2}$ equilibration method (Epstein and Mayeda, 1953) for oxygen isotopes, and by the zinc reduction method for deuterium (Coleman et al., 1982). Samples sent to Geochron Laboratories were analyzed on a VG Micromass gas source stable isotope ratio mass spectrometer (IRMS), while samples sent to CPIL were analyzed on a Thermo Finnigan Delta ${ }^{\text {PLUS }}$ XL IRMS configured with a GasBenchII gas preparation and introduction system. At each lab, one duplicate analysis on separate aliquots of the original sample was performed during each batch. Isotopic values are reported in the standard $\delta$-notation as per mil (\%) deviations from the VSMOW (Vienna Standard 
Mean Ocean Water) reference standard. Analytical precision is $\pm 0.1 \%$ and $\pm 1.0 \%$ for oxygen and deuterium, respectively.

\section{Temperature Measurements}

Onset StowAway Tidbit Temperature Loggers with $\pm 0.2^{\circ} \mathrm{C}$ accuracy were deployed at discharge measurement locations along Whychus and Indian Ford creeks and the McKinney Butte springs in late August 2007. The loggers were set using BoxCar 3.7 software to record temperature measurements every ten minutes. Data from three locations was downloaded in early September 2007 to confirm the loggers were operating properly. Loggers were removed in January 2008.

All loggers were placed in as much shade as possible to reduce temperature effects from exposure to direct sunlight. The loggers were tied to heavy-duty string and either attached to a tree on the stream bank, or secured to a stake and hammered into the channel bottom. At some point during the course of their deployment, it appears that loggers at Whychus Creek - Sisters Gage, Whychus Creek - above Chester Springs, Whychus Creek - below Frank Springs, and Indian Ford Creek Camp Polk Rd were removed from the stream. Two loggers on Whychus Creek, at Sisters Gage and below Frank Springs, were found on the bank, apparently moved during a high discharge event. The string attached to the logger on Indian Ford Creek was found cut. The logger at Whychus Creek - above Chester Springs was found in a block of ice that had formed during the course of the winter. Upon examination of the data, it was apparent that the logger at Whychus Creek - below Frank Springs was the 
first to be removed from the stream. On approximately 10/20/2007, the temperature began displaying much greater diurnal fluctuations than it had been up until then (high temperatures near $30^{\circ} \mathrm{C}$ and low temperatures below $0^{\circ} \mathrm{C}$ ). As a precaution, only data collected before 10/16/2007 has been analyzed in this study.

Groundwater temperature was measured in the Lamb Well (DESC 54659) every two hours from $01 / 11 / 2007$ to $10 / 31 / 2007$ via an internal sensor on a Unidata WDP 800720 psi transducer. The temperature sensor is accurate to $\pm 0.5^{\circ} \mathrm{C}$.

\section{Groundwater Level Measurements}

Continuous water-level measurements were monitored at the Lamb well using a battery operated electronic data recorder. The water level in the well was measured with a submersible pressure transducer. The water level was measured every two hours using a Unidata WDP 800720 psi transducer for the period between January 11, 2007 and October 31, 2007. A Druck 183020 psi transducer was used to measure the water level every 15 minutes during the period from September 10, 2007 to October 31,2007 . Both models of transducers are accurate to $0.1 \%$ of full scale $(0.015 \mathrm{~m})$. Additionally, both transducers were vented to land surface in order to compensate for barometric effects on water levels in the well bore. The transducers measured the pressure due to the weight of the overlying water column and converted it to the height above the transducer $(1 \mathrm{psi}=0.704 \mathrm{~m})$. The height of the water column was then subtracted from the depth of the transducer below land surface to obtain the water level below land surface. Water levels measured by the transducers were recorded by a 
Unidata 7000B Macrologger. The recorded data include the date and time of measurements and the height of the water column above the transducer.

The water-level recorder was visited on a 1- to 3-month schedule. Data were recorded to a computer file and graphed in the field to verify operation of the sensor. The current reading of the sensor was verified by an electronic tape (e-tape) manual water-level measurement. The e-tape is accurate to $0.003 \mathrm{~m}$.

\section{Groundwater Level Data}

Groundwater-level data along with well location information for 70 study area wells were obtained from the OWRD water level database and used to generate water level contour maps for the shallow and deep parts of the groundwater flow system. Periods of record vary considerably for each well but measurement dates ranged from 06/12/1959 to 01/06/2011. Quarterly water level measurements from two OWRD State Observation Wells (DESC 2929 and DESC 3016) were used produce a hydrograph for the purpose of examining long-term water level trends in the study area. Periods of record are 07/15/1977 to 01/06/2011 for DESC 2929 and 02/21/1962 to $01 / 06 / 2011$ for DESC 3016 .

Water level data in the OWRD database were generally provided by three sources, previous USGS studies, OWRD staff measurements, or as a part of a permit condition on a water right. The errors and uncertainties associated with groundwater level measurements are discussed below. Also discussed are the criteria used to produce the water level contour maps. 


\section{Errors and Uncertainties}

Errors and uncertainties associated with groundwater-level measurements stem from two major sources. The first source is measurement error or instrument error. This error is generally small, but differences in measurement or calibration techniques or the use of different equipment can produce errors on the order of $\pm 0.15 \mathrm{~m}$. The second source comes from the conversion from water level below land surface to water level elevation above mean sea level. Converting to an elevation normalizes the data and allows production of water level contour maps. The water level below land surface is converted to water level elevation by subtracting the water level below land surface from land surface elevation at the well head. The major source of error in this process is the well head elevation, which is interpolated from USGS 7.5 minute topographic maps. At best, the error associated with interpolation from topographic maps is $\pm 1 / 2$ of the contour interval. In the study area, contour intervals are 20 feet ( 6 $\mathrm{m})$, accordingly, well elevation errors are $\pm 3 \mathrm{~m}$.

\section{Water Level Elevation Contour Maps}

The following criteria were used to generate separate sets of water-level elevation contours for the shallow and deep parts of groundwater flow system in the study area: 1) the total depth of wells used to generate contours for the shallow part of the groundwater system was typically $<100 \mathrm{~m}$. The exception is DESC 50481, which is the westernmost and highest elevation well. DESC 50481 was originally drilled to a depth of $122 \mathrm{~m}$ and had a static water level elevation of $1052 \mathrm{~m}$ (approximately $30 \mathrm{~m}$ 
below land surface). Although the well is relatively deep compared to other wells used in the analysis, the water level is interpreted to represent the shallow part of the groundwater system because it is located close to the regional groundwater recharge area where vertical hydraulic gradients are large. This interpretation is supported by the deepening well log for DESC 50481 (DESC 51803). After the well was deepened to $181 \mathrm{~m}$, the water level elevation was $953 \mathrm{~m}$, a drop of $99 \mathrm{~m}$; 2) the total depth of most wells used to generate contours for the deep part of the groundwater system were $>100 \mathrm{~m}$, and were commonly $>150 \mathrm{~m} ; 3$ ) land surface elevations of springs that were determined to discharge local-scale groundwater were used in the generation of shallow water level contours and elevations of springs interpreted to discharge regional-scale groundwater were used to generate deep water level contours. Interpretations of the scale of groundwater discharged at study area springs are presented in Chapter 6; 4) rising or pumping water level measurements were not included in the analysis; 5) water levels from the driller's well report were excluded from analysis unless they represented the only available information in a given area; 6) the mean water level for each well was calculated for the entire period of record, and 7) the importance of each well was determined by the number of water level measurements (i.e. wells with more water level measurements were weighted more heavily). Due to the lack of a highly permeable, shallow aquifer east of McKinney Butte, the water table depth increases eastward and wells with total depths $<100 \mathrm{~m}$ are uncommon. As a result, contour mapping for the shallow aquifer stopped approximately $0.5 \mathrm{~km}$ east of the butte. 
The preceding information is summarized in Table 3 (shallow water level contours) and Table 4 (deep water level contours). Water level elevations were plotted and contoured by hand prior to digitizing using ArcMap 9.3 geographical information system software.

Errors and Uncertainties

Uncertainties associated with using this method to produce water level contour maps result from the fact that groundwater level fluctuations in the upper Deschutes Basin are driven primarily by decadal climate cycles. Decadal water-level fluctuations of $6 \mathrm{~m}$ have been observed in wells near the margin of the Cascade Range. The magnitude of these fluctuations diminishes toward the east with increasing distance from the Cascade Range (Gannett et al., 2001). The calculated mean water level in wells whose period of record does not span an entire decadal climate cycle may under estimate or over estimate the "true" mean water level depending on the timing of water-level measurements relative to climate induced fluctuations. This indicates that uncertainty in water level elevations due to decadal climate cycles could be as large as $\pm 6 \mathrm{~m}$ in the western part of the study area. This error coupled with the uncertainty in land surface elevations of wells and springs $( \pm 3 \mathrm{~m})$ could result in uncertainty on the order of $\pm 9 \mathrm{~m}$. 


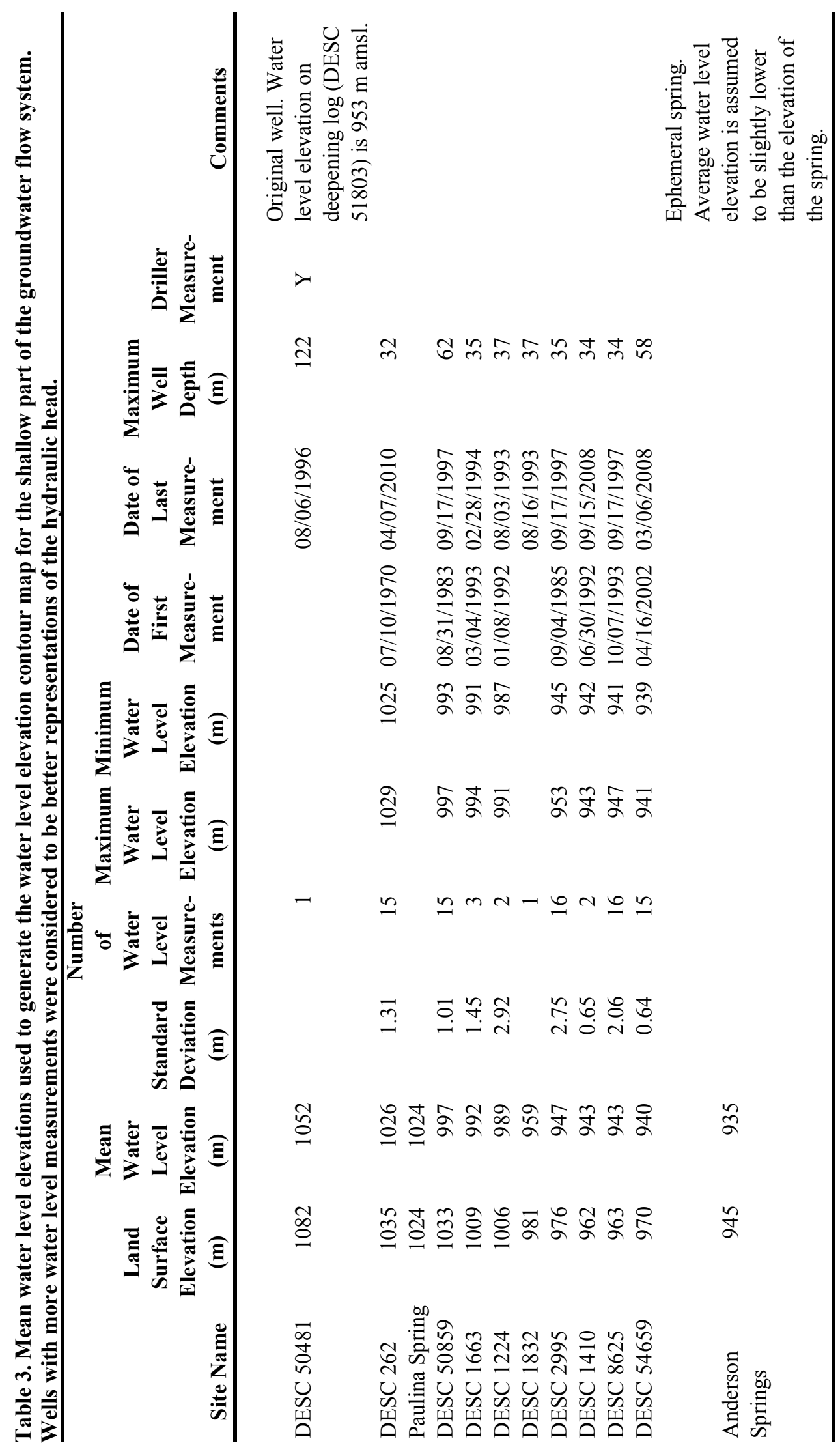




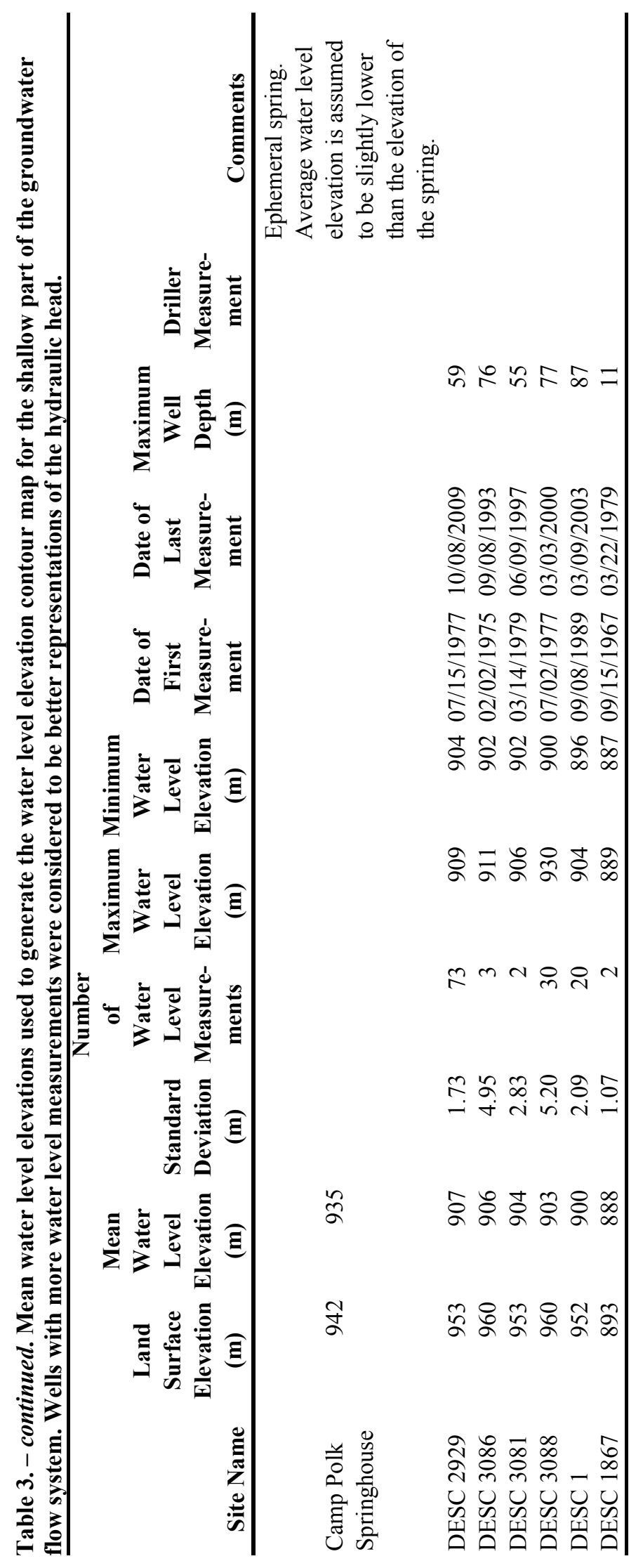




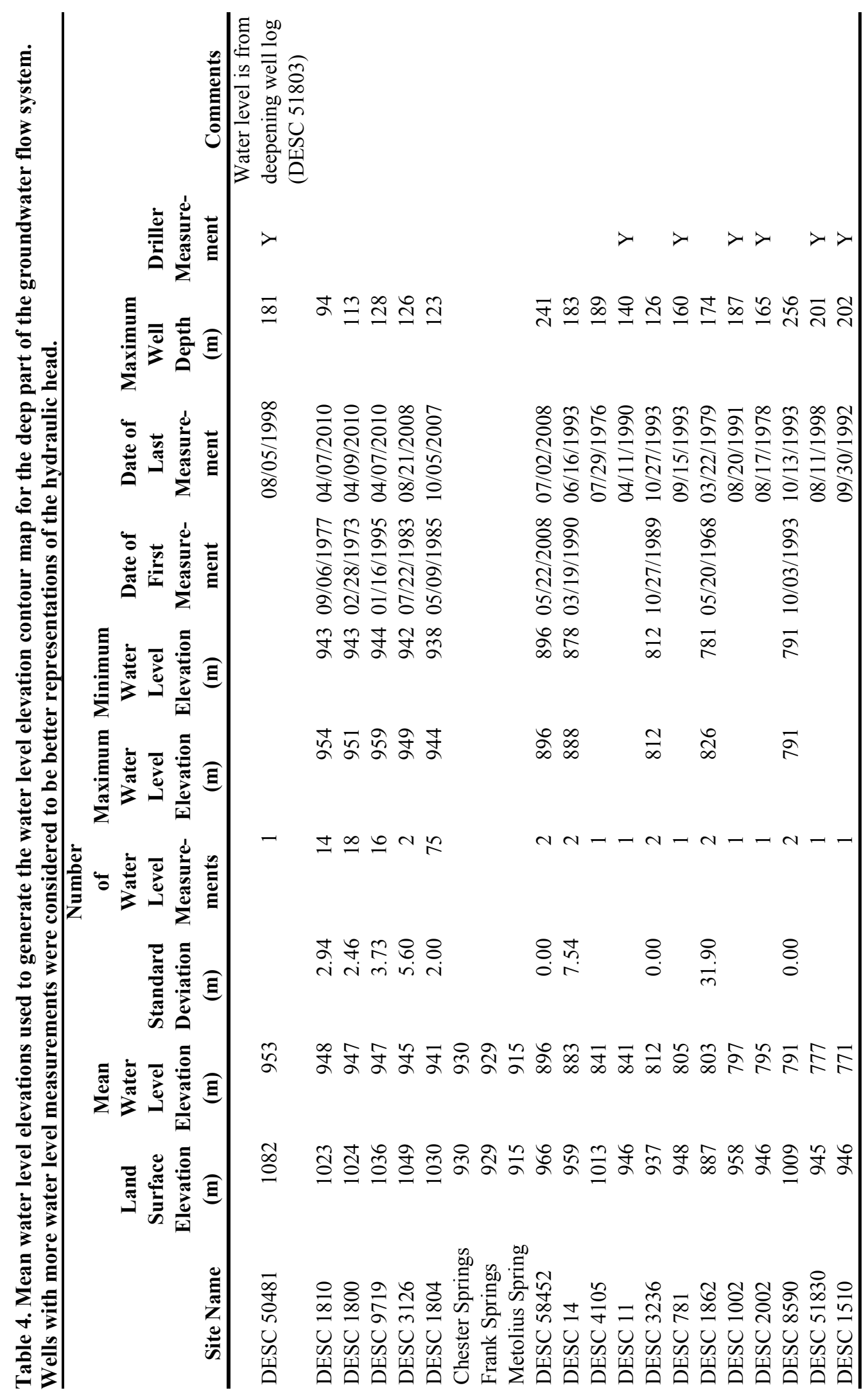




\section{Chapter 4 - Physical Hydrogeology}

\section{Results from Previous Work}

Previous studies by OWRD and the USGS have examined physical hydrogeologic characteristics of the study area. OWRD has examined groundwater flow from and to streams via synoptic discharge measurements along Whychus and Indian Ford creeks, and, as part of their Upper Deschutes Basin study, the USGS measured the discharge of springs, groundwater levels in wells, and generated a basinscale potentiometric surface map. Some results of these studies are presented below.

\section{Stream Discharge Measurements}

OWRD staff conducted seepage runs on Whychus Creek in April 1994, August 2005, March 2006, and September 2006. Seepage runs were conducted on Indian Ford Creek in February 1992, March 2006, and September 2006. Measurement locations are shown on Figure 9 and results are presented in Tables 5 and 6. Discharge errors were assigned by OWRD staff and were based on field conditions. Error values are $5 \%, 10 \%$, or $15 \%$ of the measured discharge. Discharge in relation to river mile is shown in Figure 10 for Whychus Creek and in Figure 11 for Indian Ford Creek.

In general, Whychus Creek loses discharge in the reaches upstream of Sisters, from Three Sisters Diversion Canal to Sisters (RM 24 to 21), although in March 2006 it gained streamflow from B-S Log Road to Sisters (RM 22.4 to 21). The creek also loses discharge in the reach from Sisters to Willow Lane (RM 21 to 19.4). Whychus 
Creek gains streamflow along the reaches from Willow Lane to Camp Polk Road (RM 194 to 16.6) and Camp Polk Road to Henkle Butte (RM 16.6 to 14.6). Irrigation return flows from Sokol Ditch and Reed Ditch were measured in September 2006. Both sources contribute minor amounts of streamflow, $0.019 \mathrm{~m}^{3} / \mathrm{s}$ and $0.014 \mathrm{~m}^{3} / \mathrm{s}$, respectively.

Indian Ford Creek loses discharge along the reach from Camp Polk Road to the confluence with Whychus Creek (RM 2.1 to 0.0 ). The creek was dry at Barclay Drive (RM 0.8) in February 1992 and March 2006, and was dry at Camp Polk Road in September 2006. OWRD staff has never observed flow in Indian Ford Creek at the confluence with Whychus Creek (LaMarche personal communication, 2007). 


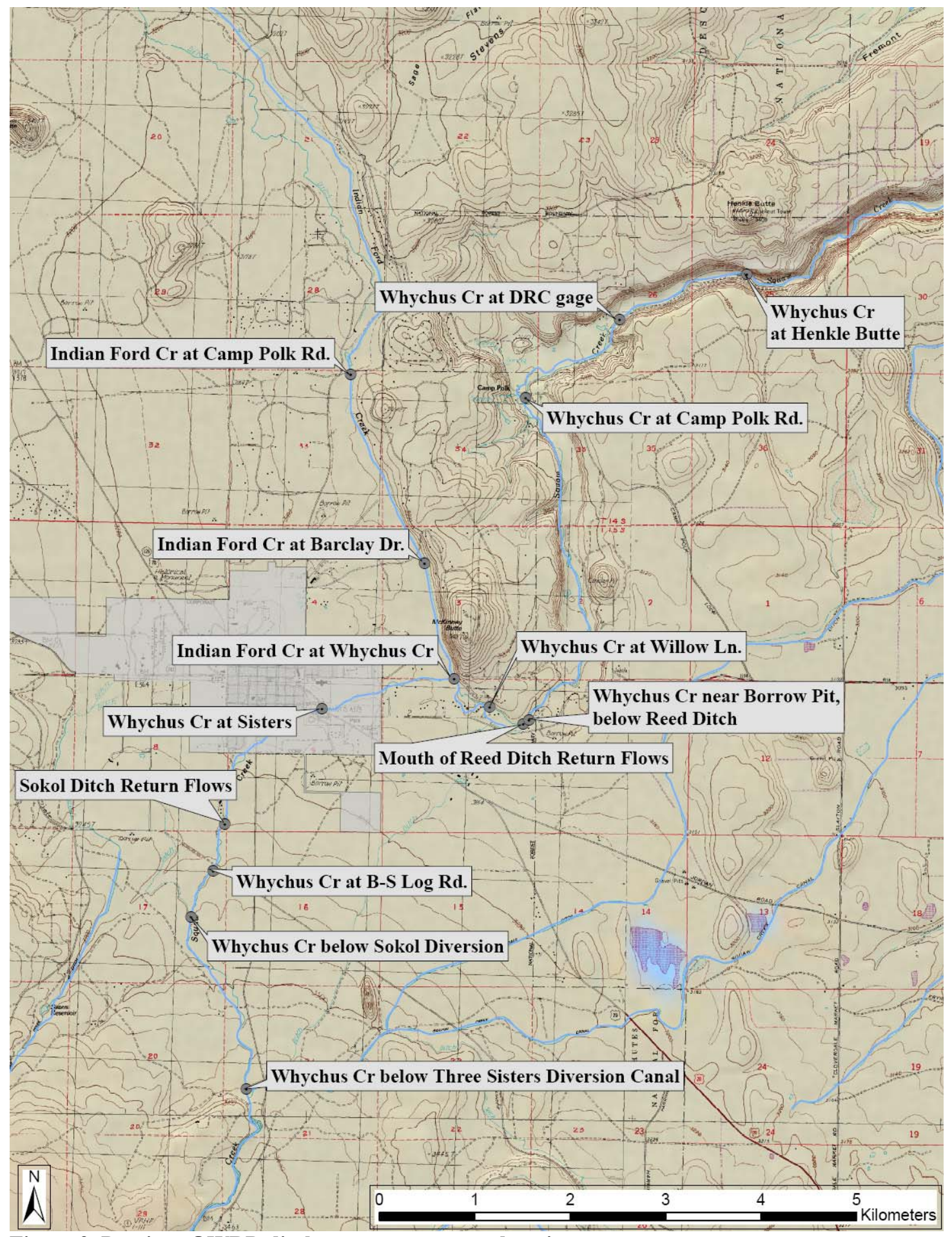

Figure 9. Previous OWRD discharge measurement locations. 
Table 5. Instantaneous discharge measurements for Whychus Creek (La Marche, personal communication 2007).

\begin{tabular}{|c|c|c|c|c|}
\hline Location & River Mile & Date & $\begin{array}{c}\text { Discharge } \\
\left(\mathrm{m}^{3} / \mathrm{s}\right)\end{array}$ & $\begin{array}{l}\text { Error } \\
\left(\mathrm{m}^{3} / \mathrm{s}\right)\end{array}$ \\
\hline Whychus $\mathrm{Cr}$ at Sisters & 21.0 & $04 / 13 / 1994$ & 0.000 & 0.000 \\
\hline Whychus Cr at Willow Ln. & 19.4 & 04/13/1994 & 0.000 & 0.000 \\
\hline Whychus Cr at Camp Polk Rd. & 16.6 & 04/13/1994 & 0.187 & 0.019 \\
\hline Whychus Cr at Henkle Butte & 14.6 & 04/13/1994 & 0.207 & 0.021 \\
\hline Whychus Cr at Sisters & 21.0 & $08 / 03 / 2005$ & 0.147 & 0.015 \\
\hline Whychus Cr at Henkle Butte & 14.6 & $08 / 03 / 2005$ & 0.198 & 0.020 \\
\hline Whychus Cr below Three Sisters Diversion Canal & 24.0 & $03 / 30 / 2006$ & 0.382 & 0.019 \\
\hline Whychus Cr at B-S Log Rd. & 22.4 & $03 / 30 / 2006$ & 0.250 & 0.013 \\
\hline Whychus $\mathrm{Cr}$ at Sisters & 21.0 & 03/30/2006 & 0.351 & 0.018 \\
\hline Whychus Cr at Willow Ln. & 19.4 & $03 / 30 / 2006$ & 0.314 & 0.016 \\
\hline Whychus Cr at Camp Polk Rd. & 16.6 & $03 / 30 / 2006$ & 0.518 & 0.026 \\
\hline Whychus Cr at DRC gage & 15.7 & $03 / 30 / 2006$ & 0.547 & 0.027 \\
\hline Whychus Cr at Henkle Butte & 14.6 & $03 / 30 / 2006$ & 0.558 & 0.028 \\
\hline Whychus Cr below Three Sisters Diversion Canal & 24.0 & $09 / 07 / 2006$ & 0.538 & 0.027 \\
\hline Whychus Cr below Sokol Diversion & 22.8 & 09/07/2006 & 0.430 & 0.022 \\
\hline Whychus Cr at B-S Log Rd. & 22.4 & 09/07/2006 & 0.388 & 0.019 \\
\hline Sokol Ditch Return Flows & 21.9 & 09/07/2006 & 0.019 & 0.001 \\
\hline Whychus $\mathrm{Cr}$ at Sisters & 21.0 & 09/07/2006 & 0.329 & 0.016 \\
\hline Whychus Cr at Willow Ln. & 19.4 & 09/07/2006 & 0.309 & 0.015 \\
\hline Mouth of Reed Ditch Return Flows & 19.2 & $09 / 07 / 2006$ & 0.014 & 0.002 \\
\hline Whychus Cr near Borrow Pit, below Reed Ditch & 19.1 & $09 / 07 / 2006$ & 0.326 & 0.016 \\
\hline Whychus Cr at Camp Polk Rd. & 16.6 & 09/07/2006 & 0.428 & 0.021 \\
\hline Whychus Cr at DRC gage & 15.7 & $09 / 07 / 2006$ & 0.442 & 0.022 \\
\hline
\end{tabular}

Table 6. Instantaneous discharge measurements for Indian Ford Creek (La Marche, personal communication 2007).

\begin{tabular}{|c|c|c|c|c|}
\hline Location & River Mile & Date & $\begin{array}{c}\text { Discharge } \\
\left(\mathrm{m}^{3} / \mathbf{s}\right)\end{array}$ & $\begin{array}{l}\text { Error } \\
\left(\mathrm{m}^{3} / \mathbf{s}\right)\end{array}$ \\
\hline Indian Ford Cr at Camp Polk Rd. & 2.1 & $02 / 05 / 1992$ & 0.086 & 0.009 \\
\hline Indian Ford $\mathrm{Cr}$ at Barclay Dr. & 0.8 & 02/05/1992 & 0.000 & 0.000 \\
\hline Indian Ford $\mathrm{Cr}$ at Whychus $\mathrm{Cr}$ & 0.0 & $02 / 05 / 1992$ & 0.000 & 0.000 \\
\hline Indian Ford Cr at Camp Polk Rd. & 2.1 & $03 / 30 / 2006$ & 0.188 & 0.028 \\
\hline Indian Ford Cr at Barclay Dr. & 0.8 & $03 / 30 / 2006$ & 0.000 & 0.000 \\
\hline Indian Ford Cr at Camp Polk Rd. & 2.1 & $09 / 07 / 2006$ & 0.000 & 0.000 \\
\hline
\end{tabular}




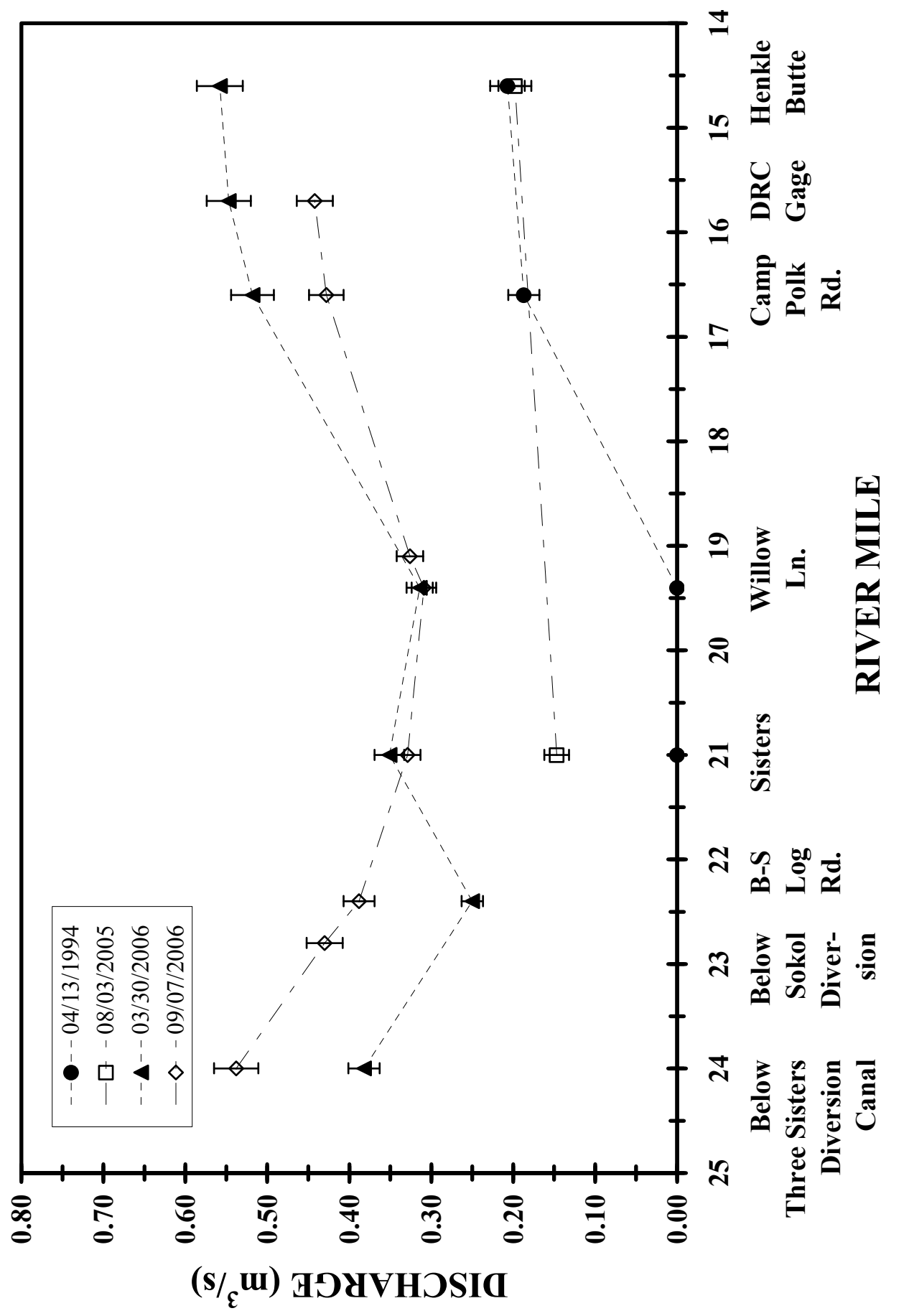




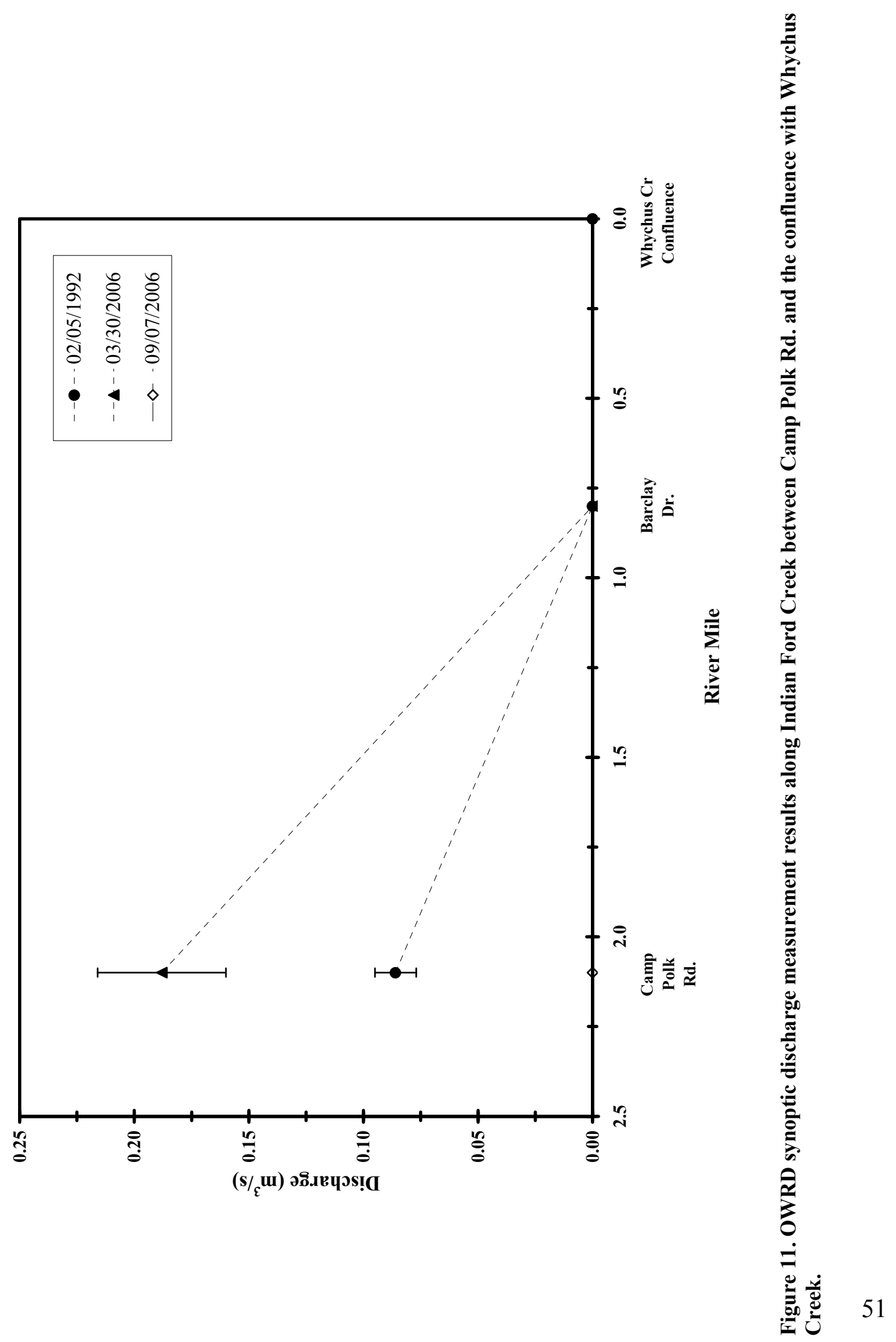




\section{Discharge Measurements of Other Significant Springs in the Region}

Spring discharge values were obtained from measurements by OWRD staff and a USGS publication, Caldwell (1998), and are presented in Table 7. Discharge from Lower Opal Springs and Alder Springs were estimated, the former by an employee of Deschutes Valley Water, and the latter by Caldwell (1998). The estimate for Lower Opal Springs is an average discharge while the estimate for Alder Springs is instantaneous. Discharge from Metolius Spring was measured by OWRD staff 16 times between 06/25/2007 and 03/03/2011 (OWRD, 2011a), and Paulina Spring was measured by OWRD staff on 07/12/1995 (Caldwell, 1998). The accuracy or uncertainty of each discharge was not provided, but measurements are assumed to be within $10 \%$ of the true discharge and estimates are assumed to be within one order of magnitude $( \pm 100 \%)$. Discharge from Alder Springs and Paulina Spring is much lower than Lower Opal Springs and Metolius Spring (locations shown in Figure 3).

Table 7. Discharge values for local springs.

\begin{tabular}{lccl}
\hline \multicolumn{1}{c}{ Location } & Date & Discharge $\left(\mathbf{m}^{3} / \mathbf{s}\right)$ & \multicolumn{1}{c}{ Remarks } \\
\hline Lower Opal Springs & 1996 & 6.8 & estimated average flow rate* \\
Alder Springs & $01 / 18 / 1996$ & $0.11-0.14$ & estimated flow rate* \\
Paulina Spring & $07 / 12 / 1995$ & 0.176 & measured by OWRD staff* \\
Metolius Spring & $06 / 25 / 2007-03 / 03 / 2011$ & $1.92-2.83$ & measured by OWRD staff \\
\hline
\end{tabular}

* From Caldwell (1998)

\section{Potentiometric Surface Mapping}

A potentiometric surface map of the Upper Deschutes basin was produced by Gannett and Lite (2004). Figure 12 shows their contours in the vicinity of the current study area. Their work demonstrated that groundwater flows from high-elevation recharge areas in the Cascade Range toward low-elevation discharge areas near the 
margins of the Cascade Range and near the confluence of the Deschutes, Crooked, and Metolius Rivers. Their map also shows a steep groundwater flow gradient in the Cascades that becomes increasingly flat toward the center of the basin near the town of Sisters. 


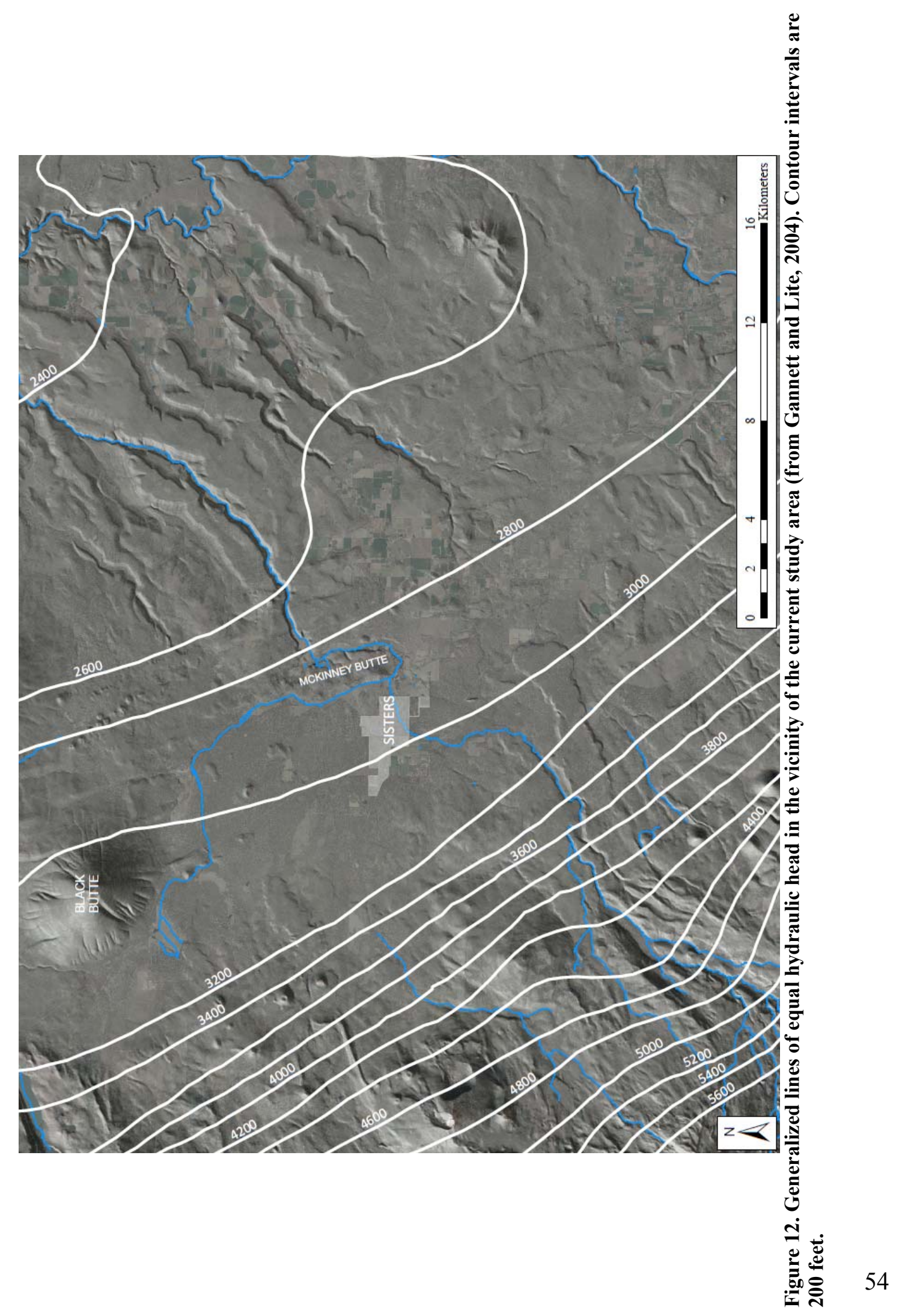




\section{Results from Current Study}

\section{Stream Discharge}

Instantaneous stream discharge was measured on a seasonal basis between April 2007 and January 2008 and the results are presented in Tables 8 and 9 (measurement locations shown on Figure 2) Discharge in relation to river mile is shown in Figure 13 for Whychus Creek and in Figure 14 for Indian Ford Creek.

In both Whychus and Indian Ford creeks, discharge increased during the winter and decreased during the summer (Tables 8 and 9, Figures 13 and 14). Discharge in Indian Ford Creek decreased downstream indicating it is losing water to the groundwater system. On 06/25/2007 and 09/21/2007 Indian Ford Creek went dry upstream from Camp Polk Road, and on 04/16/2007 and 01/30/2008 the creek went dry between Camp Polk Road and Barclay Drive. No water was observed in Indian Ford Creek at its confluence with Whychus Creek. Discharge in Whychus Creek typically increased downstream (Table 8 and Figure 13), but occasional downstream decreases in discharge were observed.

Measurement sites on Whychus Creek have been divided into four reaches based on location to better facilitate analysis and discussion (Figure 13). Reach 1 extends from Sisters to above Chester Springs (RM 21 to RM 18.4), Reach 2 begins at the above Chester Springs site and extends to below Frank Springs (RM 18.4 to RM 17.5), Reach 3 begins at the below Frank Springs site and ends at Camp Polk Road 
(RM 17.5 to RM 16.6), and Reach 4 starts at Camp Polk Road and ends at DRC gage

(RM 16.6 to RM 15.7).

Table 8. Discharge measurements and calculated errors for Whychus Creek.

\begin{tabular}{|c|c|c|c|c|c|c|}
\hline Location & River Mile & Date & $\begin{array}{c}\text { Discharge } \\
\left(\mathrm{m}^{3} / \mathrm{s}\right)\end{array}$ & $\begin{array}{c}S_{q} \\
(\%)\end{array}$ & $\begin{array}{c}E_{\text {sv }} \\
\left(\mathrm{m}^{3} / \mathrm{s}\right)\end{array}$ & $\begin{array}{c}E_{t} \\
\left(\mathrm{~m}^{3} / \mathrm{s}\right)\end{array}$ \\
\hline Whychus Cr at Sisters & 21.0 & $04 / 16 / 2007$ & 0.552 & 4.40 & 0.009 & $\mathbf{0 . 0 3 3}$ \\
\hline Whychus $\mathrm{Cr}$ at Willow Ln. & 19.4 & $04 / 16 / 2007$ & 0.581 & 4.28 & 0.009 & 0.034 \\
\hline Mouth of Reed Ditch & 19.2 & $04 / 16 / 2007$ & 0.000 & - & - & - \\
\hline Whychus Cr below Reed Ditch & 19.1 & $04 / 16 / 2007$ & 0.564 & 4.31 & 0.009 & 0.033 \\
\hline Whychus $\mathrm{Cr}$ above Chester springs & 18.4 & $04 / 16 / 2007$ & 0.547 & 4.31 & 0.009 & 0.033 \\
\hline Whychus Cr below Chester springs & 17.9 & $04 / 16 / 2007$ & 0.552 & 4.35 & 0.009 & $\mathbf{0 . 0 3 3}$ \\
\hline Whychus Cr below Frank springs & 17.5 & $04 / 16 / 2007$ & 0.734 & 4.33 & 0.009 & 0.041 \\
\hline Whychus Cr at Camp Polk Rd. & 16.6 & $04 / 16 / 2007$ & 0.745 & 4.34 & 0.009 & 0.041 \\
\hline Whychus $\mathrm{Cr}$ at Sisters & 21.0 & $06 / 25 / 2007$ & 0.249 & 4.53 & 0.025 & $\overline{0.036}$ \\
\hline Whychus $\mathrm{Cr}$ above Chester springs & 18.4 & $06 / 25 / 2007$ & 0.199 & 4.43 & 0.025 & 0.034 \\
\hline Whychus Cr below Frank springs & 17.5 & $06 / 25 / 2007$ & 0.340 & 4.45 & 0.025 & 0.040 \\
\hline Whychus Cr at Camp Polk Rd. & 16.6 & $06 / 25 / 2007$ & 0.379 & 4.43 & 0.025 & 0.042 \\
\hline Whychus $\mathrm{Cr}$ at DRC gage & 15.7 & $06 / 25 / 2007$ & 0.368 & 4.43 & 0.025 & 0.041 \\
\hline Whychus Cr at Sisters & 21.0 & $09 / 21 / 2007$ & 0.396 & 4.48 & 0.027 & 0.045 \\
\hline Whychus $\mathrm{Cr}$ above Chester springs & 18.4 & $09 / 21 / 2007$ & 0.346 & 4.36 & 0.027 & 0.042 \\
\hline Whychus Cr below Frank springs & 17.5 & $09 / 21 / 2007$ & 0.538 & 4.35 & 0.027 & 0.050 \\
\hline Whychus $\mathrm{Cr}$ at Camp Polk Rd. & 16.6 & 09/21/2007 & 0.513 & 4.38 & 0.027 & 0.049 \\
\hline Whychus Cr at DRC gage & 15.7 & $09 / 21 / 2007$ & 0.501 & 4.35 & 0.027 & 0.049 \\
\hline Whychus Cr at Sisters & 21.0 & $01 / 30 / 2008$ & 1.694 & 4.22 & 0.020 & 0.091 \\
\hline Whychus $\mathrm{Cr}$ above Chester springs & 18.4 & $01 / 30 / 2008$ & 1.648 & 4.22 & 0.020 & 0.089 \\
\hline Whychus Cr below Frank springs & 17.5 & $01 / 30 / 2008$ & 1.849 & 4.23 & 0.020 & 0.098 \\
\hline Whychus Cr at Camp Polk Rd. & 16.6 & $01 / 30 / 2008$ & 1.878 & 4.24 & 0.020 & 0.100 \\
\hline Whychus $\mathrm{Cr}$ at DRC gage & 15.7 & $01 / 30 / 2008$ & 1.994 & 4.22 & 0.020 & 0.104 \\
\hline
\end{tabular}

$\mathbf{S}_{\mathbf{q}}=$ standard error, $\mathbf{E}_{\mathrm{sv}}=$ error due variability in stream discharge, and $\mathbf{E}_{\mathbf{t}}=$ total error.

Table 9. Discharge measurements and calculated errors for Indian Ford Creek.

\begin{tabular}{|c|c|c|c|c|}
\hline Location & River Mile & Date & $\begin{array}{c}\text { Discharge } \\
\left(\mathrm{m}^{3} / \mathrm{s}\right)\end{array}$ & $\begin{array}{l}\text { Error } \\
\left(\mathrm{m}^{3} / \mathrm{s}\right)\end{array}$ \\
\hline Indian Ford Cr at Camp Polk Rd. & 2.1 & $04 / 16 / 2007$ & 0.091 & 0.013 \\
\hline Indian Ford $\mathrm{Cr}$ at Barclay Dr. & 0.8 & $04 / 16 / 2007$ & 0.000 & 0.000 \\
\hline Indian Ford Cr at Camp Polk Rd. & 2.1 & $06 / 25 / 2007$ & 0.000 & 0.000 \\
\hline Indian Ford $\mathrm{Cr}$ at Barclay Dr. & 0.8 & $06 / 25 / 2007$ & 0.000 & 0.000 \\
\hline Indian Ford Cr at Camp Polk Rd. & 2.1 & $09 / 21 / 2007$ & 0.000 & 0.000 \\
\hline Indian Ford $\mathrm{Cr}$ at Barclay Dr. & 0.8 & $09 / 21 / 2007$ & 0.000 & 0.000 \\
\hline Indian Ford Cr at Camp Polk Rd. & 2.1 & $01 / 30 / 2008$ & 0.081 & 0.012 \\
\hline Indian Ford $\mathrm{Cr}$ at Barclay Dr. & 0.8 & $01 / 30 / 2008$ & 0.000 & 0.000 \\
\hline
\end{tabular}


As shown in Figure 15, measured discharge decreased along Reach 1.

However, the difference in discharge between Sisters and above Chester Springs was within the margin of measurement error and may not represent actual losses. Within Reach 1, measured discharge increased from Sisters to Willow Lane (RM 21 to 19.4, 04/16/2007 seepage run) and decreased from Willow Lane to below Reed Ditch (RM 19.4 to $19.1,04 / 16 / 2007$ seepage run). Once again, however, the calculated gains and losses were within measurement error, and may not represent actual changes in discharge.

Streamflow measurements along Reach 2 were used to estimate discharge from the McKinney Butte Springs. Therefore, results for this reach will be presented in the McKinney Butte Springs Discharge section later in this chapter.

Measured discharge along Reach 3 increased on 04/16/2007, 06/25/2007, and 01/30/2008, and decreased on 09/21/2007 (Figure 16). However, the gains and losses were less than calculated errors and therefore may not represent actual gains or losses.

Similar to Reach 3, measured discharge along Reach 4 decreased during some seepage runs (06/25/2007 and 09/21/2007) and increased during others (01/30/2008), but once again, the magnitude of the gains or losses were less than the calculated errors (Figure 17). Discharge was not measured at the DRC gage during the 04/16/2007 seepage run, thus no gain/loss value is presented. 


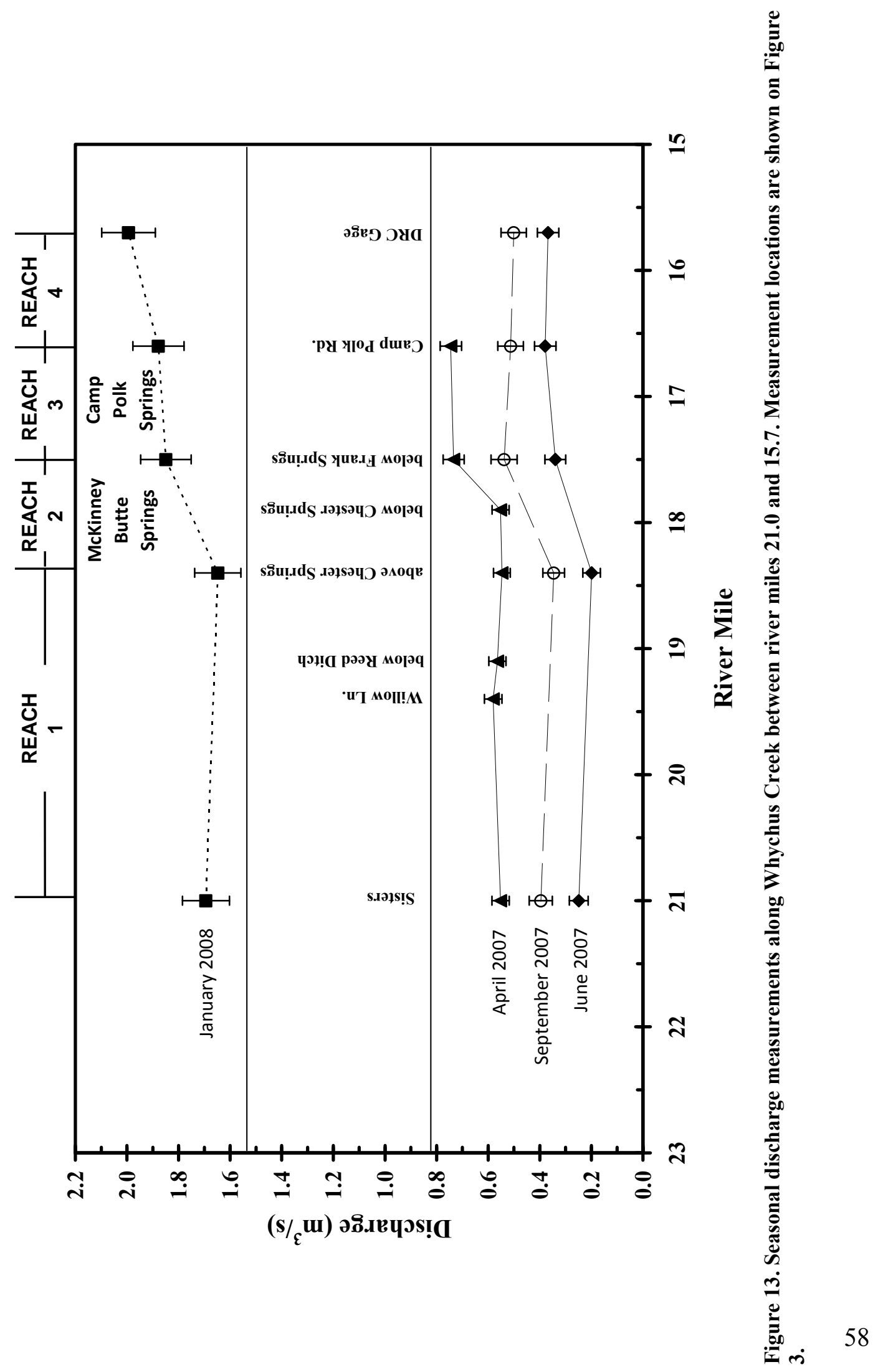



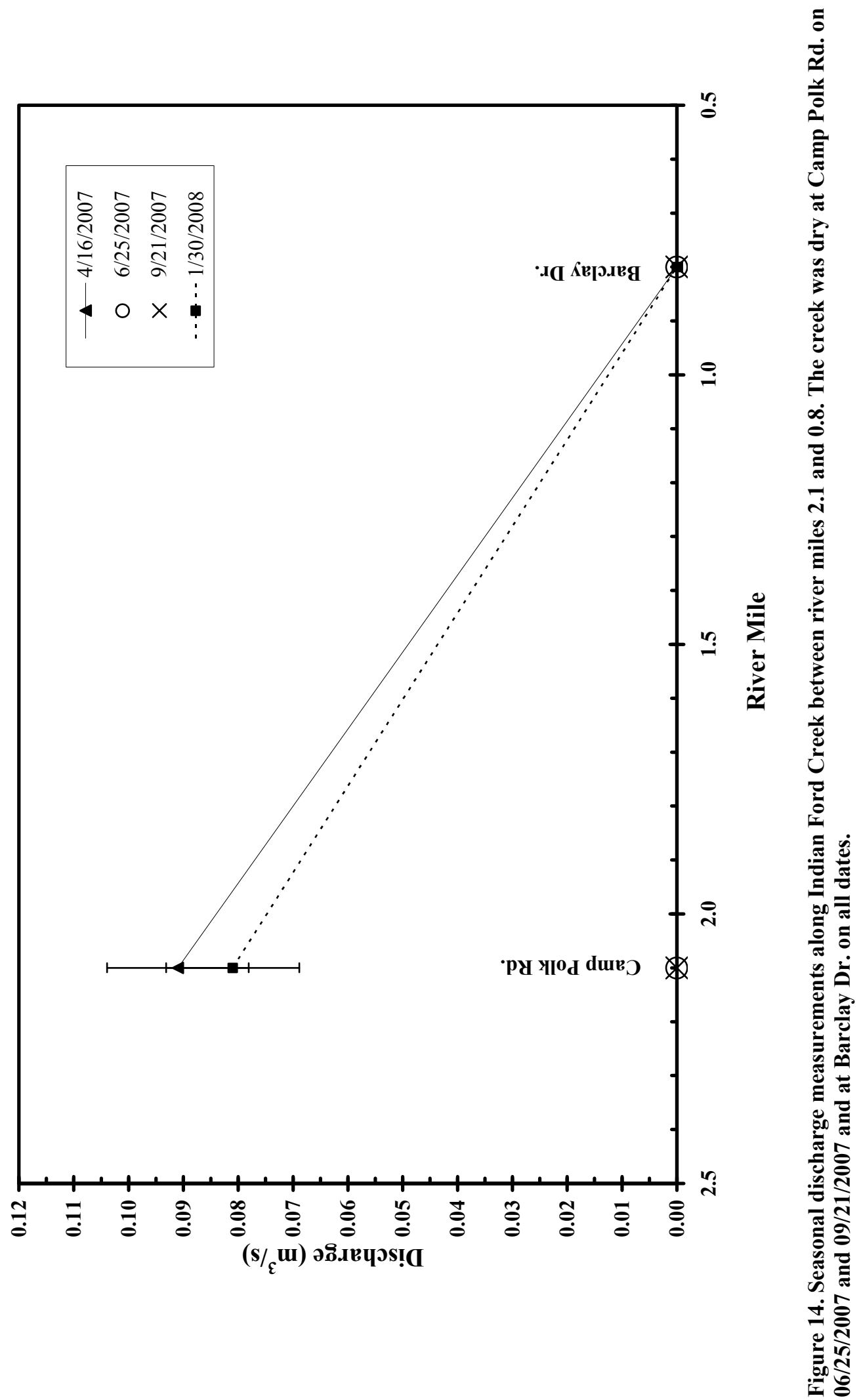


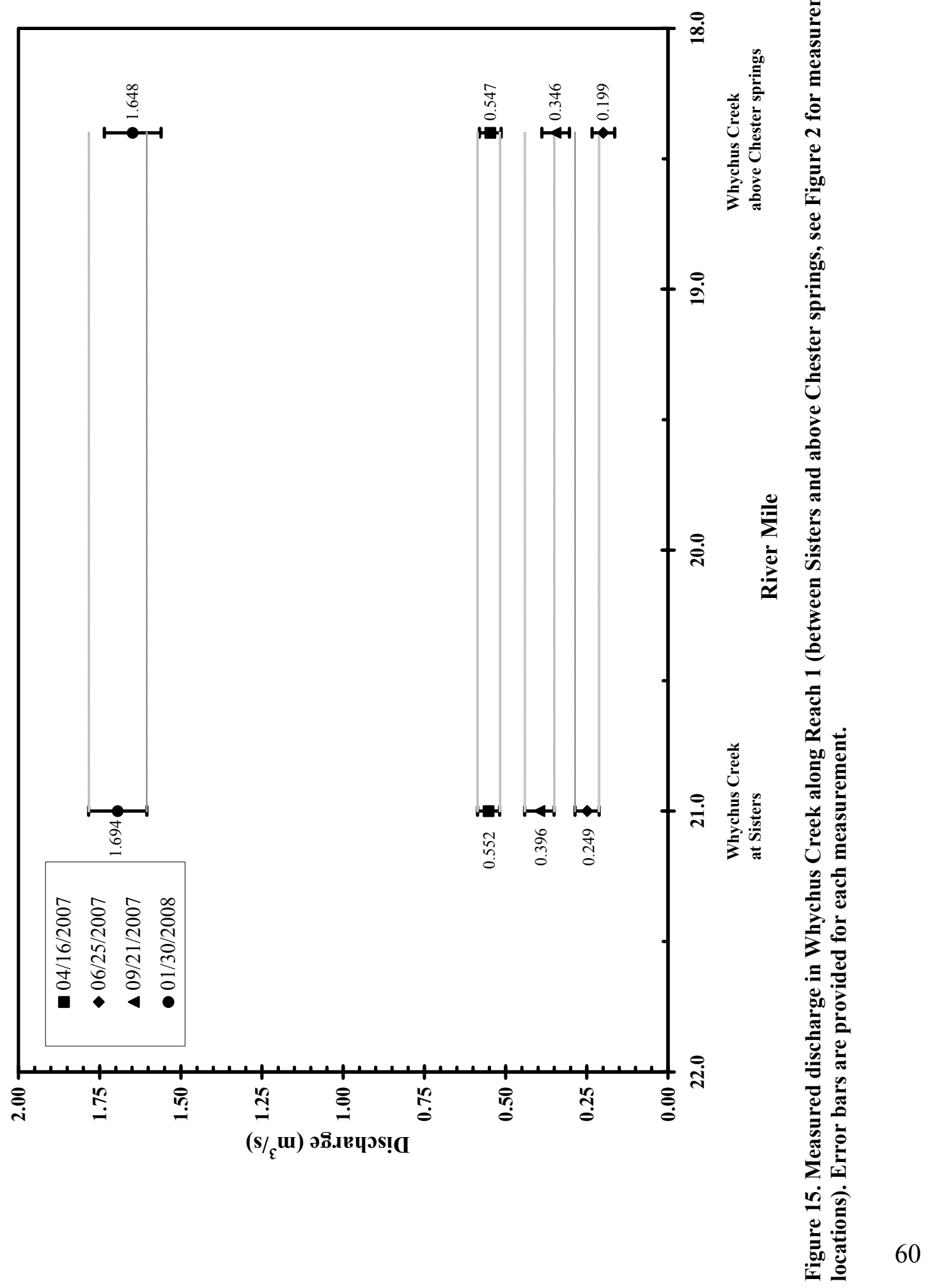




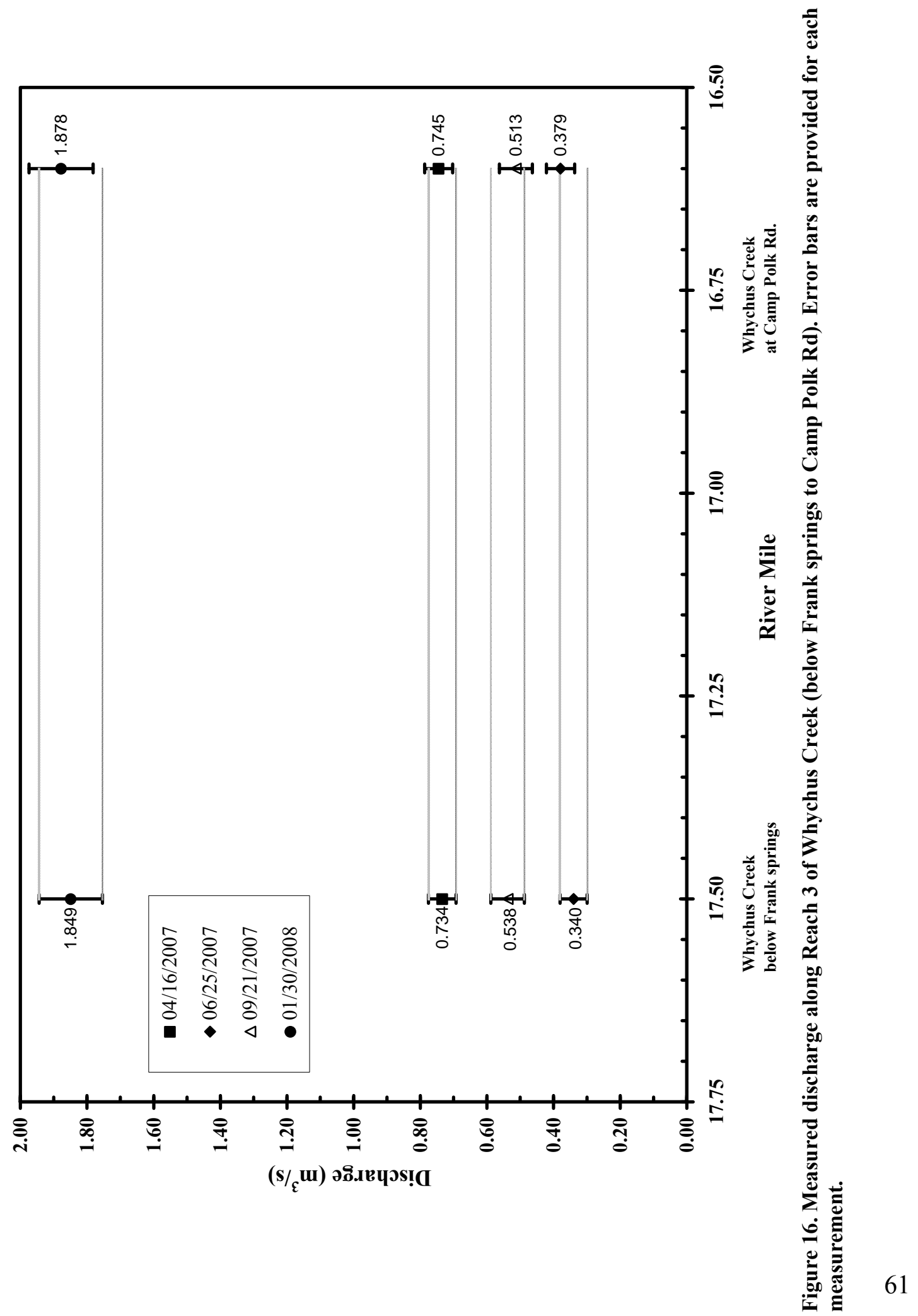




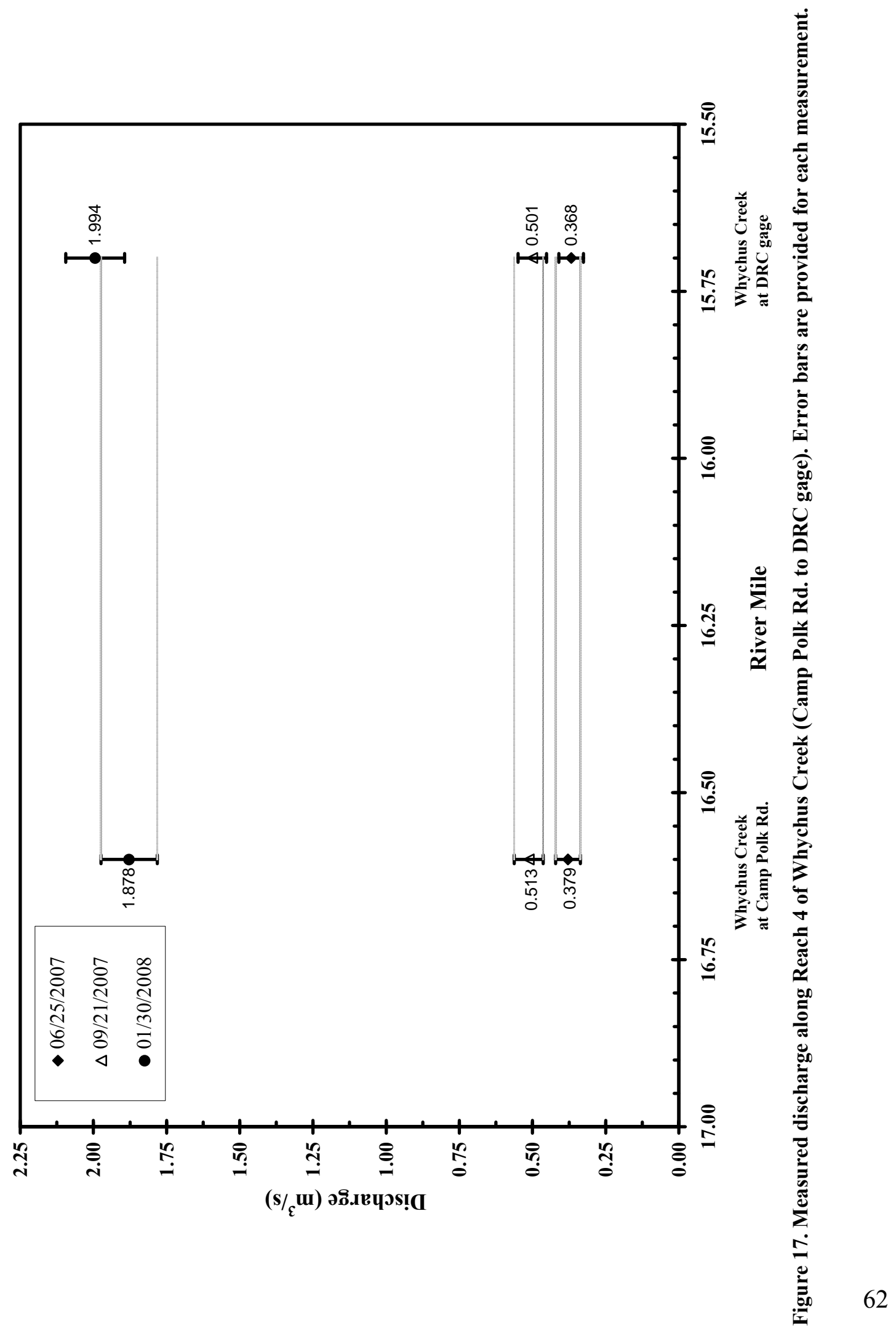




\section{Discharge from the McKinney Butte Springs}

Discharge from the McKinney Butte Springs was determined by subtracting the measured discharge in Whychus Creek above Chester Springs from the measured discharge in Whychus Creek below Frank Springs. These two measurement sites, along with the site below Chester Springs define flow along Reach 2 as described in the previous section.

Seepage runs indicated Whychus Creek gained discharge along Reach 2 (Figure 18) and measured gains were sufficiently large with respect to measurement error to be considered meaningful. Table 10 provides the calculated gain on each date and the error associated with each gain. The calculated gain column in Table 10 represents the estimated discharge from the McKinney Butte Springs. Errors were calculated using equation A13; a complete discussion of errors is presented in Appendix A. Calculated discharge from the McKinney Butte Springs ranged from $0.141 \pm 0.052 \mathrm{~m}^{3} / \mathrm{s}$ on $06 / 25 / 2007$ to $0.201 \pm 0.132 \mathrm{~m}^{3} / \mathrm{s}$ on $01 / 30 / 2008$. Although the discharge was largest on $01 / 30 / 2008$, the associated error was also largest, and as a result, the actual springs discharge could vary by up to $64 \%$ (true discharge could range from 0.072 to $0.330 \mathrm{~m}^{3} / \mathrm{s}$ ) from the calculated discharge (Table 10). In addition to measurement sites above Chester Springs (RM 18.4) and below Frank Springs (RM 17.5), discharge was measured below Chester Springs (RM 17.9) on 04/16/2007. From the above Chester Springs site to the below Chester Springs site, the measured discharge in Whychus Creek increased from $0.547 \mathrm{~m}^{3} / \mathrm{s}$ to $0.552 \mathrm{~m}^{3} / \mathrm{s}$. This gives an 
estimate of $0.005 \mathrm{~m}^{3} / \mathrm{s}$ discharge from Chester Springs. However, the estimated discharge is much less than the calculated error of $0.047 \mathrm{~m}^{3} / \mathrm{s}$, so the true discharge from Chester Springs is uncertain. On the same date, discharge in Whychus Creek from below Chester Springs to below Frank Springs increased from $0.552 \mathrm{~m}^{3} / \mathrm{s}$ to $0.734 \mathrm{~m}^{3} / \mathrm{s}$, providing an estimated discharge of $0.182 \mathrm{~m}^{3} / \mathrm{s}$ from Frank Springs. The associated error is $0.053 \mathrm{~m}^{3} / \mathrm{s}$ ( $29 \%$ uncertainty), which indicates the true discharge from Frank Springs on 04/16/2007 was between $0.129 \mathrm{~m}^{3} / \mathrm{s}$ and $0.235 \mathrm{~m}^{3} / \mathrm{s}$. 


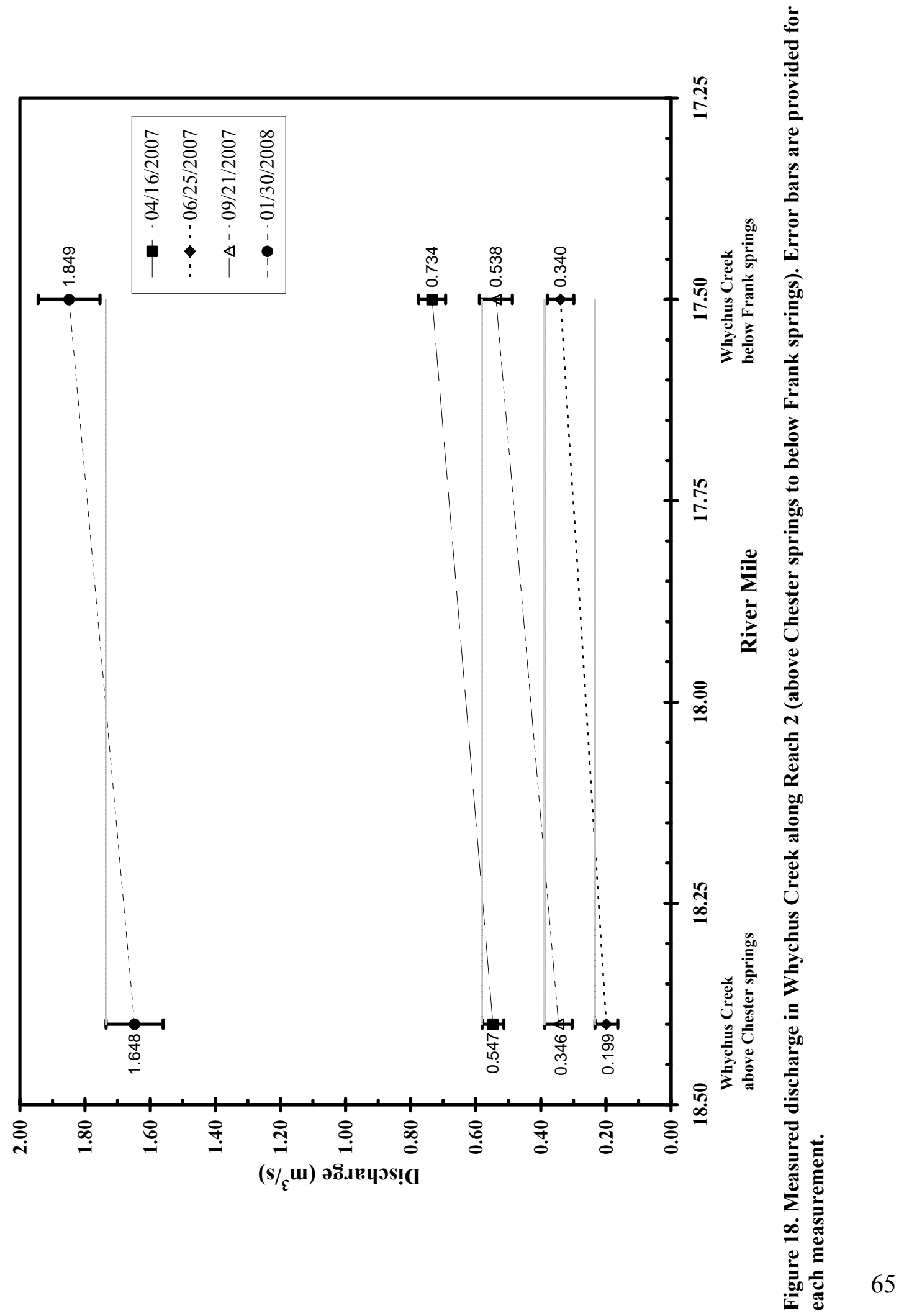


Table 10. Measured discharge along Reach 2 of Whychus Creek.

\begin{tabular}{|c|c|c|c|c|c|c|}
\hline Date & $\begin{array}{c}\text { Discharge } \\
\text { below Frank } \\
\text { springs } \\
\left(\mathrm{m}^{3} / \mathrm{s}\right)\end{array}$ & $\begin{array}{c}\text { Discharge } \\
\text { above Chester } \\
\text { springs } \\
\left(\mathrm{m}^{3} / \mathbf{s}\right)\end{array}$ & $\begin{array}{c}\text { Calculated } \\
\text { Gain } \\
\left(\mathbf{m}^{3} / \mathbf{s}\right)\end{array}$ & $\begin{array}{c}\text { \% Variability } \\
\text { ((error/gain)*100) }\end{array}$ & $\begin{array}{c}\text { Minimum } \\
\text { Gain } \\
\left(\mathrm{m}^{3} / \mathbf{s}\right)\end{array}$ & $\begin{array}{l}\text { Maximum } \\
\text { Gain } \\
\left(\mathrm{m}^{3} / \mathbf{s}\right)\end{array}$ \\
\hline $4 / 16 / 2007$ & $0.734 \pm 0.041$ & $0.547 \pm 0.033$ & 0.187 & 28 & 0.134 & 0.240 \\
\hline $6 / 25 / 2007$ & $0.340 \pm 0.040$ & $0.199 \pm 0.034$ & 0.141 & 37 & 0.089 & 0.193 \\
\hline $9 / 21 / 2007$ & $0.538 \pm 0.050$ & $0.346 \pm 0.042$ & 0.192 & 34 & 0.127 & 0.257 \\
\hline $1 / 30 / 2008$ & $1.849 \pm 0.098$ & $1.648 \pm 0.089$ & 0.201 & 66 & 0.069 & 0.333 \\
\hline
\end{tabular}

\section{Groundwater Level Measurements}

Automated groundwater level measurements were collected at the Lamb Well on McKinney Butte (DESC 54659, site location on Figure 2) from 01/11/2007 to $10 / 31 / 2007$. Data were collected at 2-hour intervals from $01 / 11 / 2007$ to $10 / 31 / 2007$

(Figure 19), and at 15-minute and 2-hour intervals from 09/10/2007 to 10/31/2007 (Figure 20). Manual water level measurements were collected periodically between $11 / 15 / 2006$ and $03 / 06 / 2008$. Water level elevations fluctuate seasonally with the highest elevations occurring in winter and spring, and the lowest levels in summer and fall. The total amount of fluctuation during the continuous data collection period was $1.50 \mathrm{~m}$; water level elevations ranged from $941.27 \mathrm{~m}$ above mean sea level (msl) on 01/11/2007 to $939.77 \mathrm{~m}$ above $\mathrm{msl}$ on $10 / 05 / 2007$. The highest manually measured water level elevation was $941.70 \mathrm{~m}$ above msl on 03/06/2008 (Figure 19). From April 2007 to October 2007 water levels in the well fluctuated diurnally by approximately $0.3 \mathrm{~m}$ (Figure 19). These diurnal fluctuations are more readily seen on Figure 21, a plot showing water levels in the Lamb Well during July 2007. The maximum daily water level typically occurred between 16:00 and 20:00 and the daily minimum occurred at 06:00 (Figure 21). Diurnal fluctuations of this magnitude coincide with the 
local irrigation season and were not observed before April 2007 or after October 2007 (Figure 19).

A comparison of water level trends in the Lamb Well with accumulated precipitation at the Three Creeks Meadow SNOTEL site is presented in Figure 22. The location of Three Creeks Meadow relative to Sisters and the Lamb Well is shown in Figure 3. Water level trends in the Lamb Well appear to be influenced, at least during some parts of the year, by precipitation. Water levels in the well rise during times of higher precipitation and fall during periods of lower precipitation (Figure 22).

Water levels trends in the Lamb Well are also very similar to discharge trends in Whychus Creek. Figure 23 is a plot of daily mean discharge at the OWRD gage in Sisters and water level elevations in the Lamb Well. Peaks in discharge appear to coincide with water level peaks. 


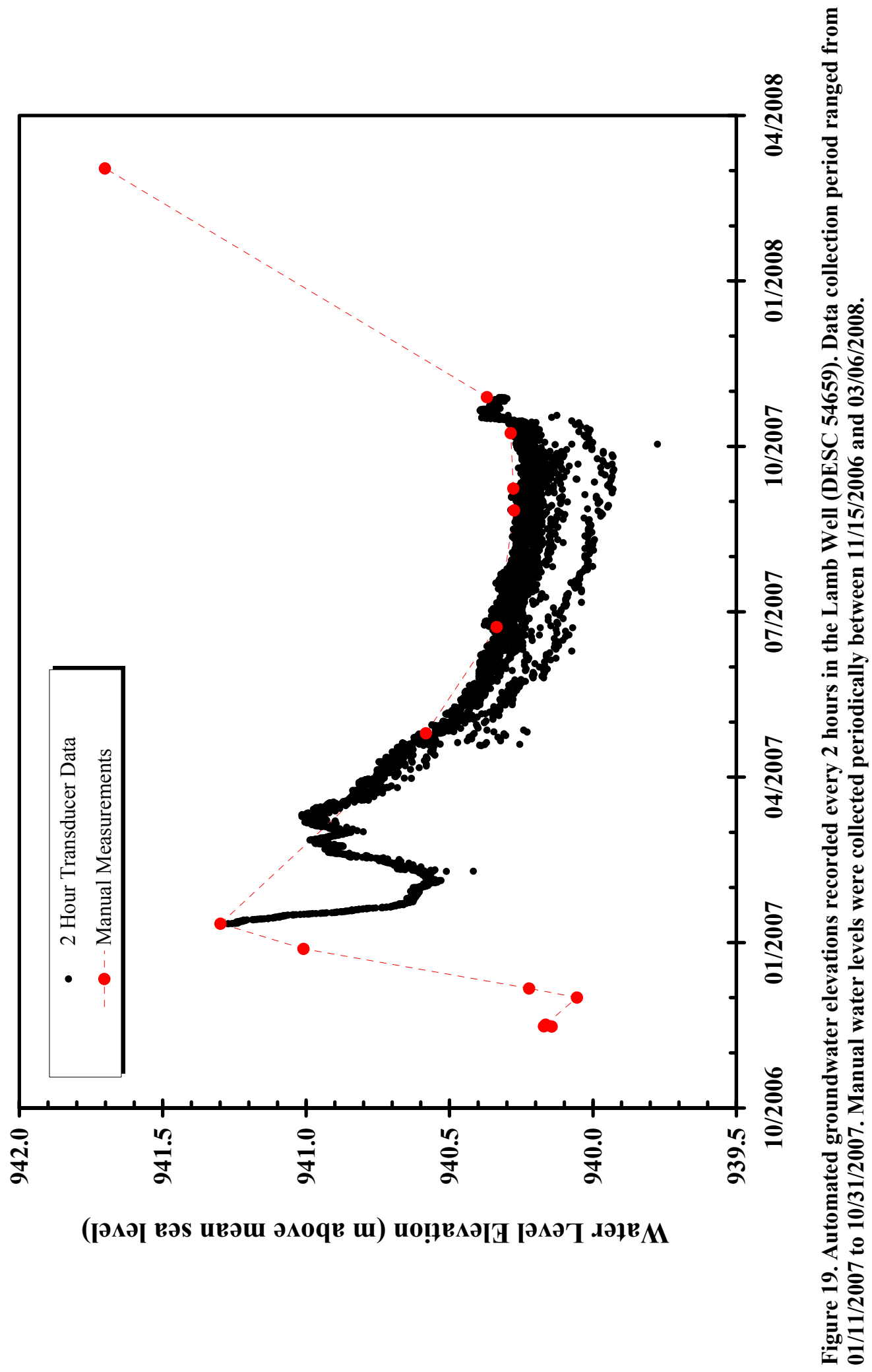




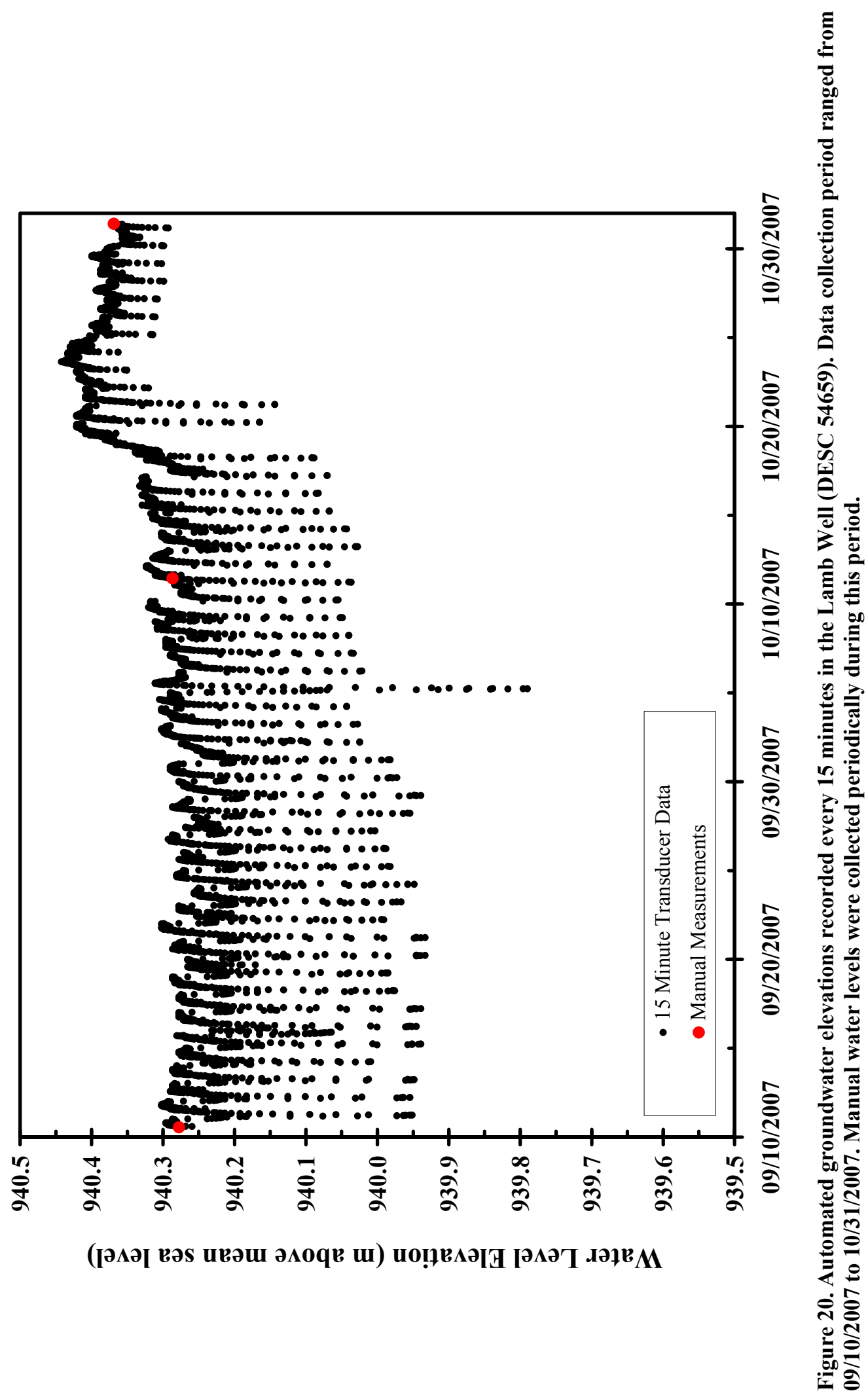




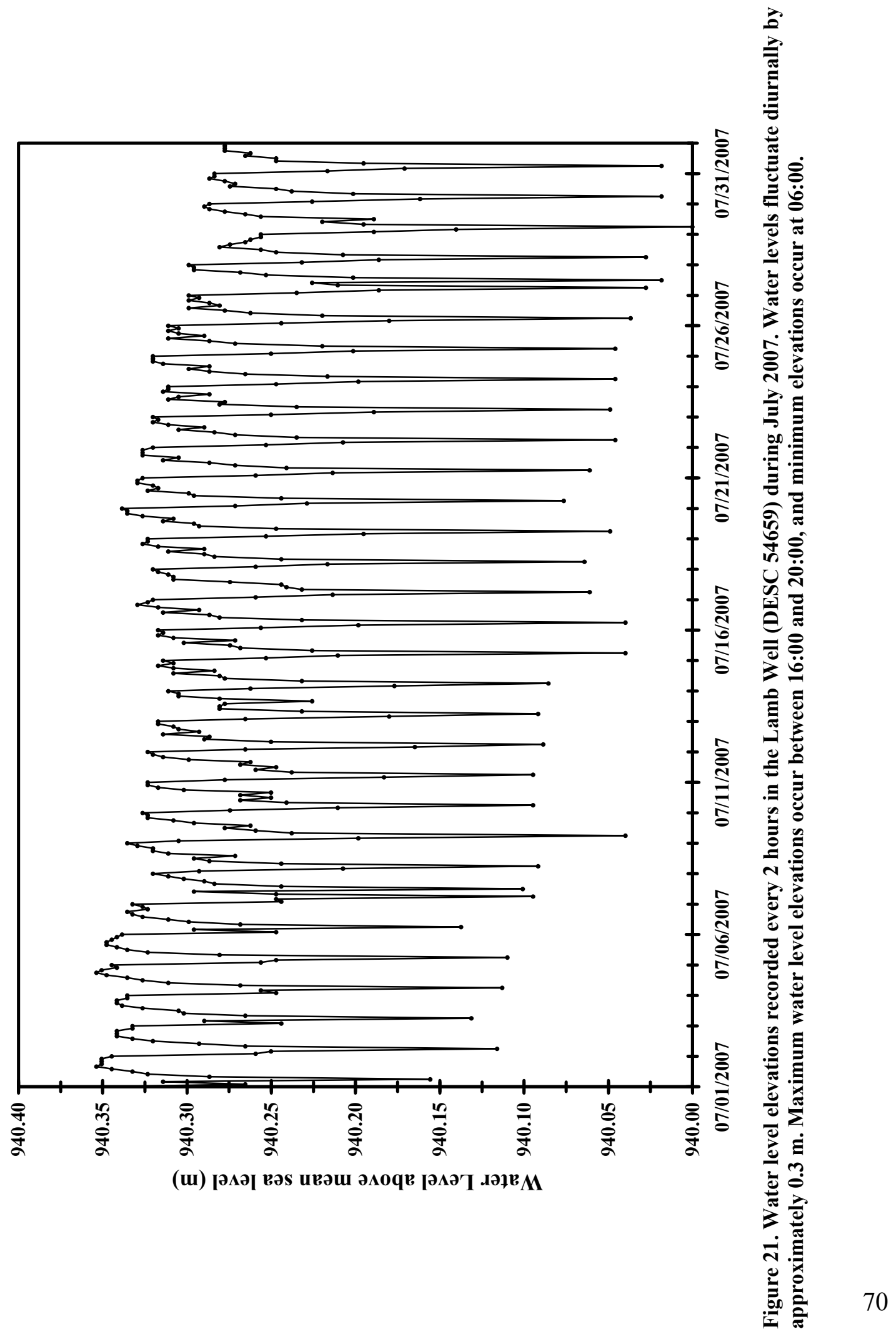




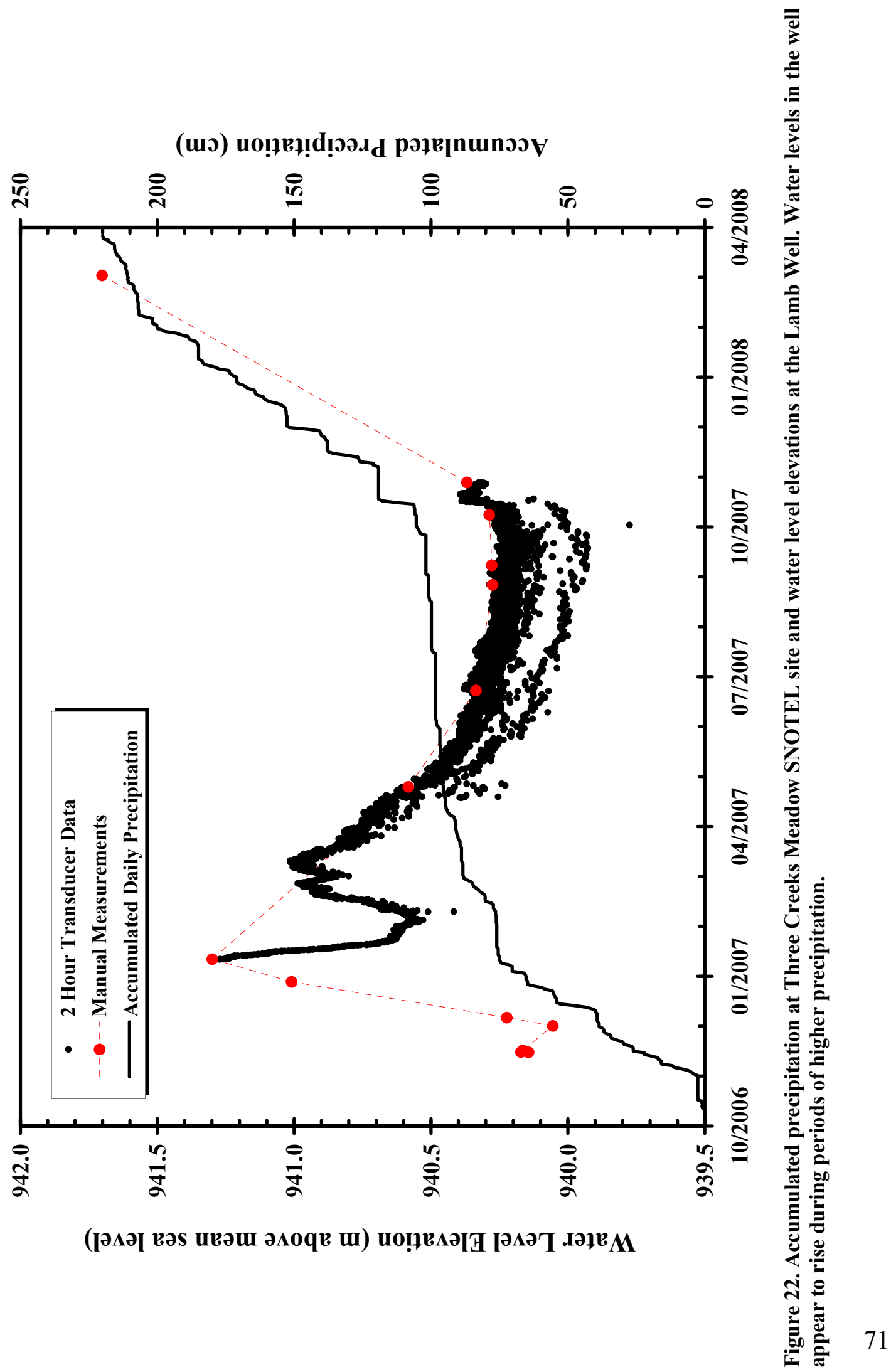




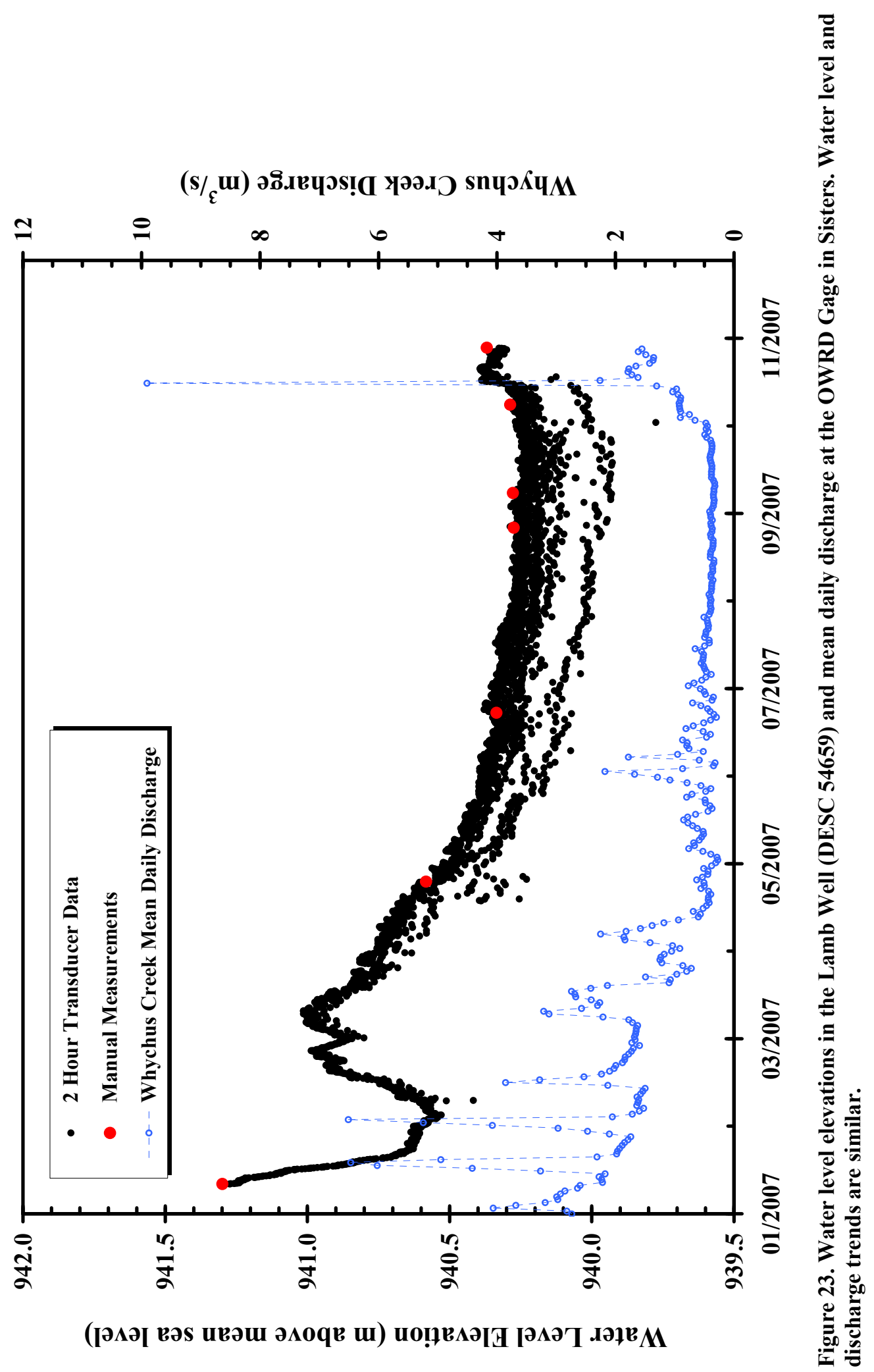




\section{Hydrographs}

Figure 25 is a plot of water levels in the Lamb Well (DESC 54659) and the two state observation wells nearest to McKinney Butte. DESC 3016, located west of McKinney Butte, is $70 \mathrm{~m}$ deep and is completed in Quaternary lavas of the Cascades Range, while DESC 2929 is 59 m deep and is completed in the Deschutes Formation. Well locations are shown on Figure 24. Long-term water level trends for these wells show fluctuations in response to decadal climate cycles (Figure 25). The magnitude of the response is greater in DESC 3016 because it is closer to the regional recharge area, but historically, both wells responded to climatic cycles almost concurrently.

However, DESC 2929 has not responded to the current period of higher precipitation that began in 2006, while the water level in DESC 3016 has risen almost $3 \mathrm{~m}$ (Figure 25). The period of record in the Lamb Well is not long enough to determine if it is following decadal climate cycles. 


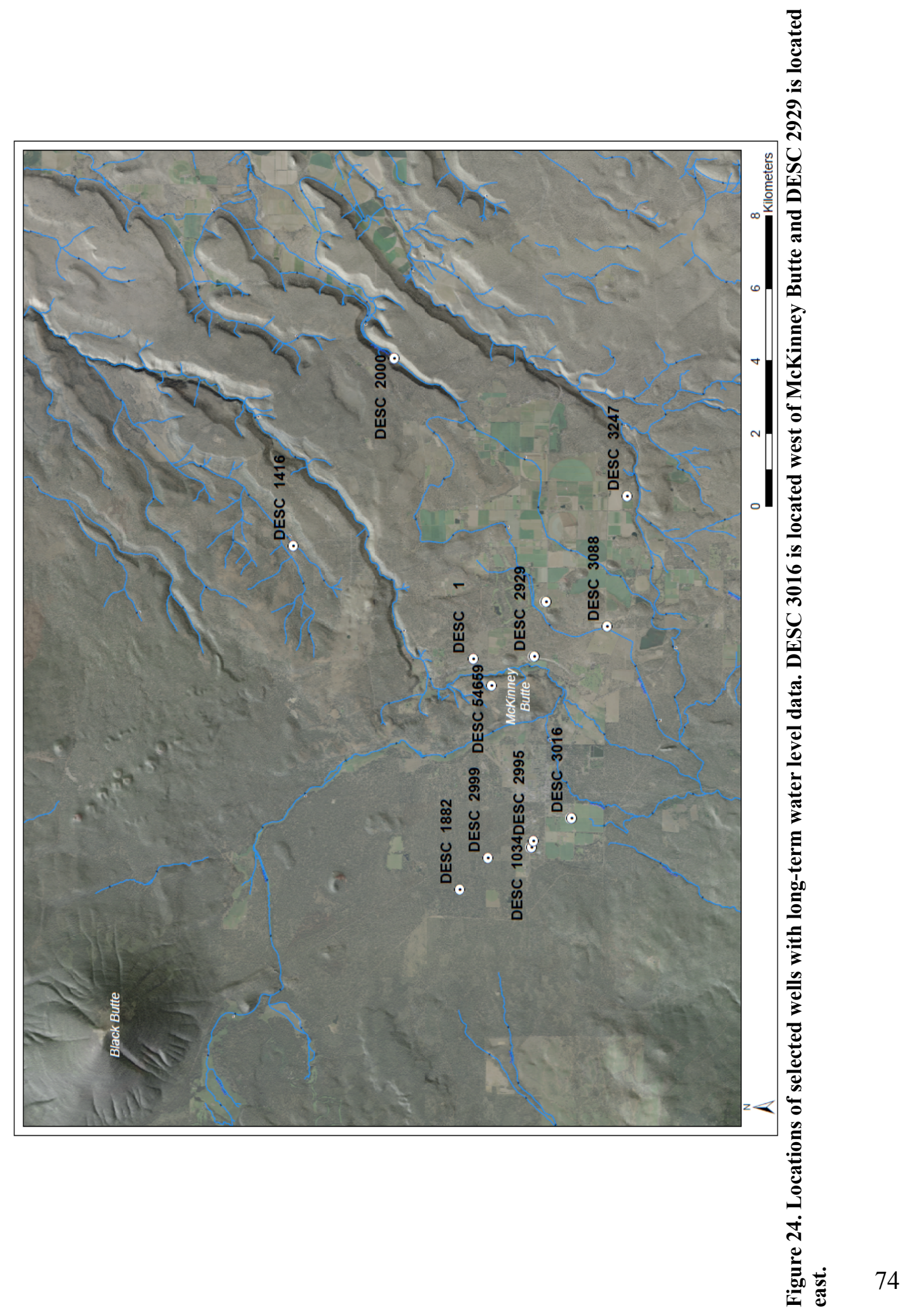




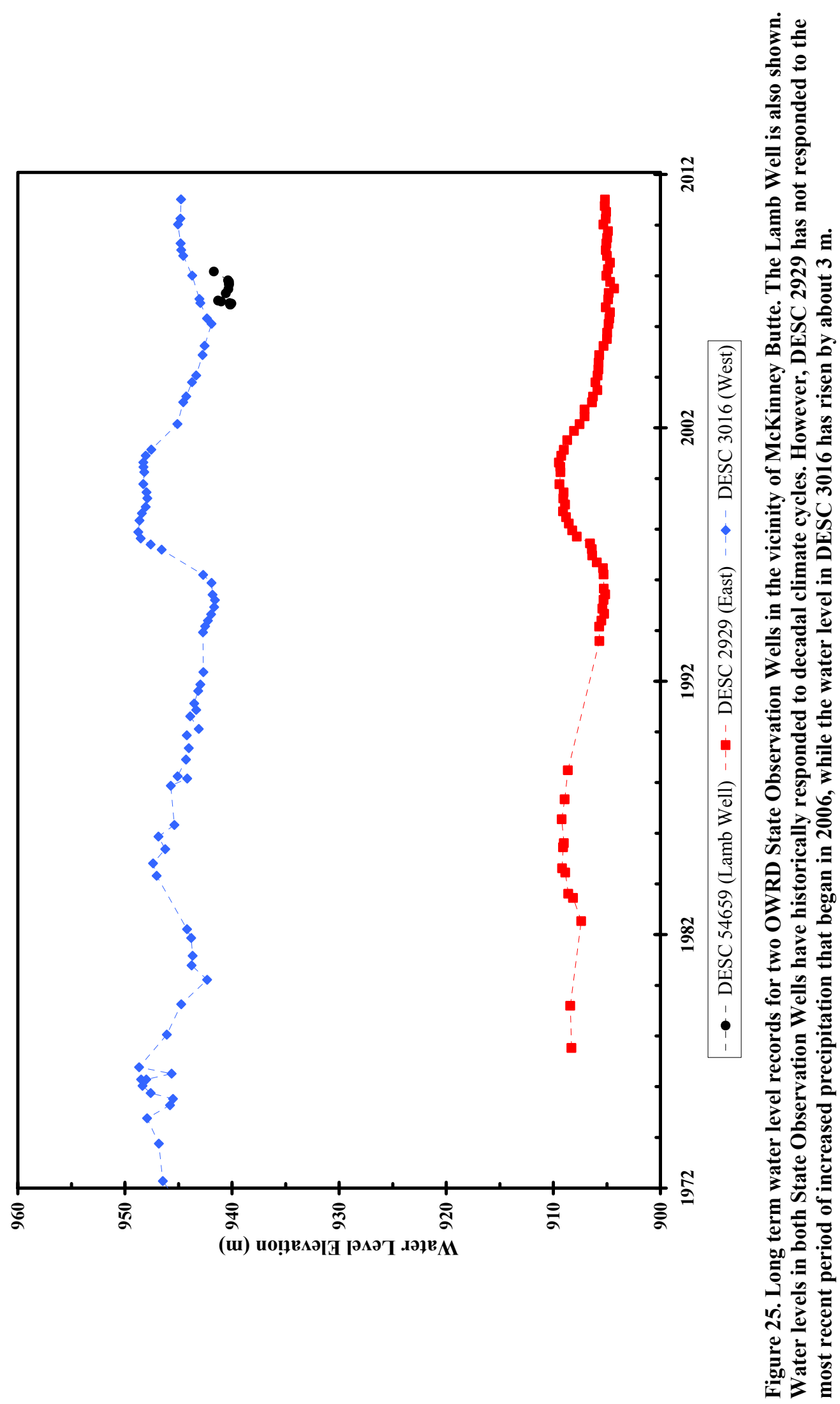




\section{Water Level Contour Mapping}

Separate sets of water-level elevation contours were generated for the shallow (Figure 26) and deep (Figure 27) parts of groundwater flow system in the study area. Water level elevation contours in the shallow part of the system to the west of McKinney Butte are more widely spaced than contours east of the butte, indicating that the horizontal groundwater gradient increases across the butte (Figure 26). The same can be said for contours in the deep part of the system; however, the gradient west of McKinney Butte is extremely small (approximately $4 \mathrm{~m} / \mathrm{km}$ ) while the gradient east of the butte is exceptionally large (approximately $60 \mathrm{~m} / \mathrm{km}$ ) (Figure 27). Vertical gradients between the shallow and deep parts of the system are highest in the western part of the study area (60 m difference) and decrease to about $15 \mathrm{~m}$ on the east edge of McKinney Butte. 


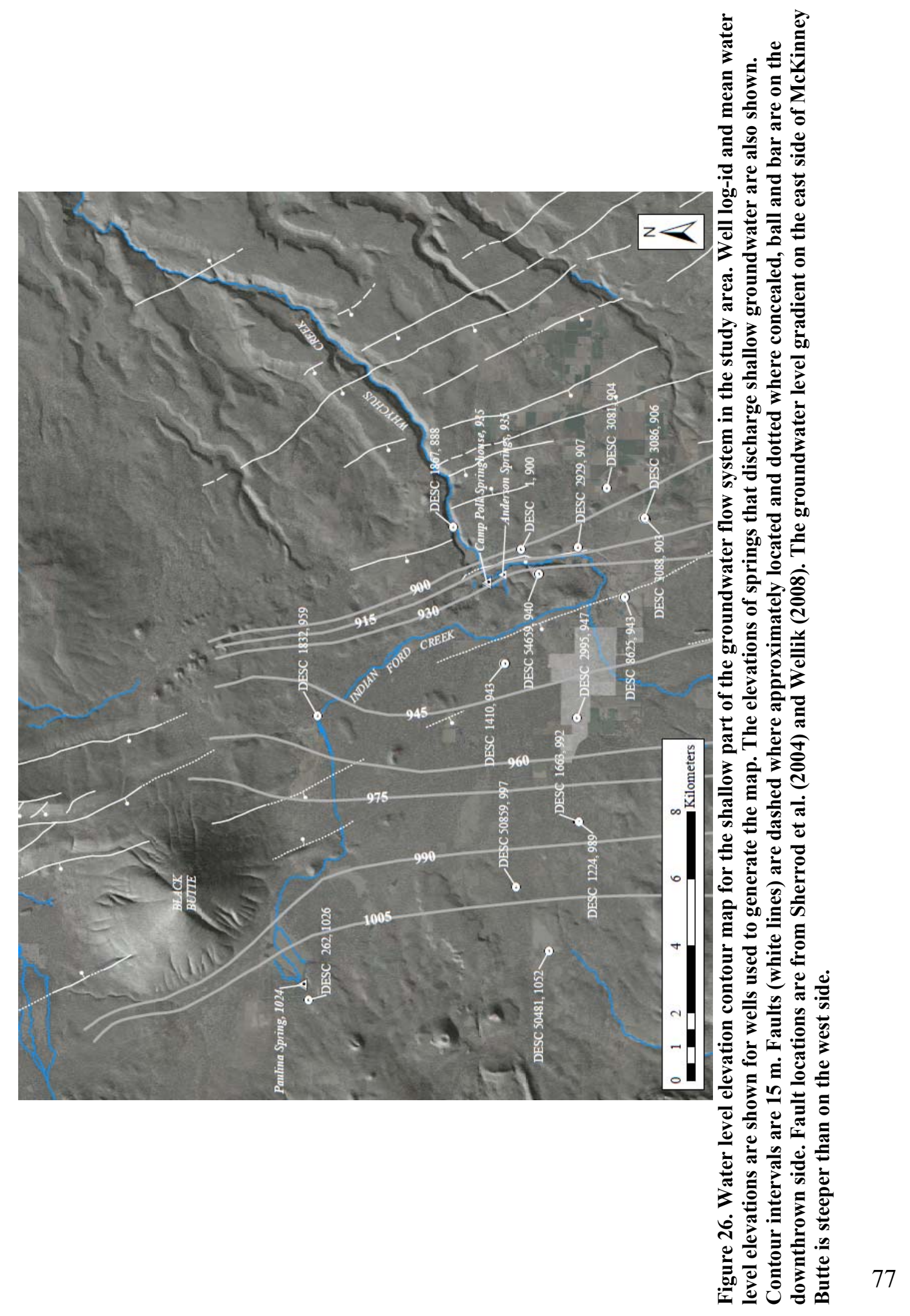




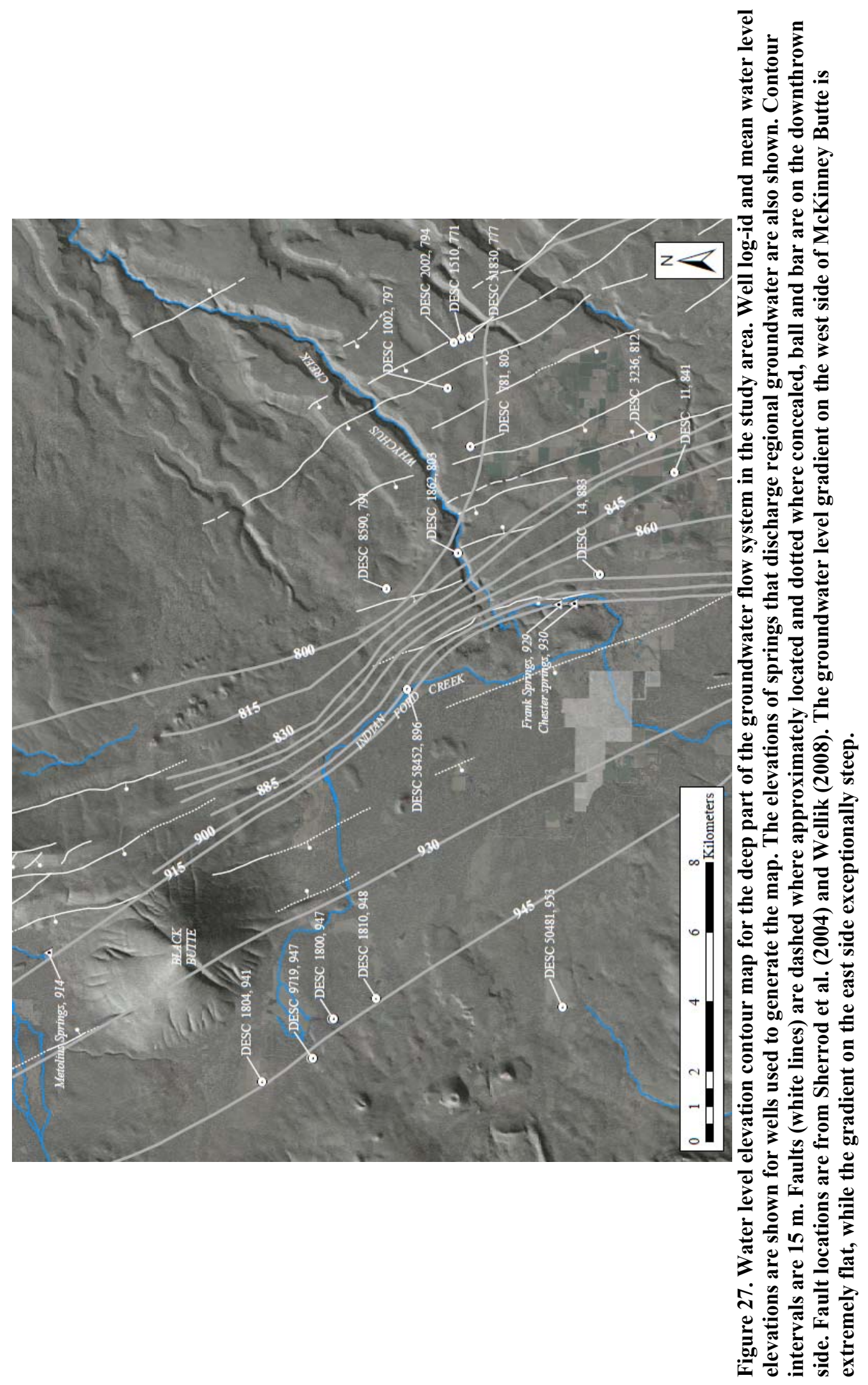




\section{Chapter 5 - Chemical Hydrogeology}

The geochemistry of groundwater and surface water sources in and around the study area are described in this section. Results from analysis of field parameters and common ions are presented first, followed by stable isotopes and temperature. Data from previous studies are presented for comparison purposes.

\section{Results}

\section{General Chemistry}

A total of 52 samples were collected from study area springs and streams. Thirty-one samples were collected from Whychus and Indian Ford creeks, and 21 samples were collected from the McKinney Butte Springs, the Camp Polk Springs, Paulina Spring, Alder Springs, and Metolius Spring. Site location information and field parameters (temperature, $\mathrm{pH}$, and electrical conductivity) are presented in Table 11; major-element chemistry and stable isotope data are listed in Table 12. Charge balance errors (CBEs) were calculated using Visual Minteq and ranged from -18.04 to to $8.39 \%$ (Table 11 ). The majority of samples (43 of 52) had CBEs $<10 \%$, and only three samples had CBEs $>15 \% . \mathrm{PO}_{4}$ was detected in many samples, however, measured concentrations were typically below the minimum reporting limit; consequently, $\mathrm{PO}_{4}$ concentrations were excluded from further analysis. The reader is referred to Appendix B for a discussion of the determination of the minimum reporting limit. 
Several graphs, designed to display similarities and differences among samples, are presented later in this section. In order to reduce clutter and promote clarity, in some instances Whychus Creek samples from sites upstream from any spring inputs were plotted as one group called "Whychus Creek above the McKinney Butte Springs". Sites included in this group are Whychus Creek at Sisters Gage, Whychus Creek at Reed Ditch, and Whychus Creek above Chester Springs. Similarly, samples from sites downstream from the McKinney Butte Springs were plotted as the group "Whychus Creek below the McKinney Butte Springs". Sites in this group are Whychus Creek below Frank Springs, Whychus Creek at Camp Polk Rd, and Whychus Creek at DRC Gage. Samples from all sites on Indian Ford Creek were grouped together and plotted as "Indian Ford Creek".

Water samples have traditionally been classified on the basis of dominant cationic and anionic species (Hem, 1985). Waters in which more than 50 percent of cations (expressed in milliequivalents per liter (meq/L)) are $\mathrm{Mg}, \mathrm{Na}+\mathrm{K}$, or $\mathrm{Ca}$ are described as $\mathrm{Mg}, \mathrm{Na}$ or $\mathrm{Ca}$ waters, respectively. Similarly, waters in which more than 50 percent of anions are $\mathrm{SO}_{4}, \mathrm{Cl}$, or $\mathrm{CO}_{3}+\mathrm{HCO}_{3}$ are described as $\mathrm{SO}_{4}, \mathrm{Cl}$, or $\mathrm{HCO}_{3}$ waters. If no ionic species comprises more than 50 percent of the total cationic or anionic concentration, the water is classified as mixed-type. Thirty-four of the fiftytwo samples analyzed during this study are mixed cation-bicarbonate water. Sixteen samples are sodium-bicarbonate water and two samples are magnesium-bicarbonate water. Bicarbonate is the dominant anionic species in all samples, commonly comprising up to $90 \%$ of total anion concentration (Figure 28 ). 
Table 11. Location information and summary of field parameters collected sampling locations during the current study and previous studies. Blank records indicate the parameter was not measured.

\begin{tabular}{|c|c|c|c|c|c|c|c|}
\hline Latitude & Longitude & Name & $\begin{array}{c}\text { Elev. } \\
\text { (m) }\end{array}$ & $\begin{array}{c}\text { Date } \\
(\mathrm{mo} / \mathrm{d} / \mathrm{yr})\end{array}$ & $\begin{array}{c}\text { Temp. } \\
\left({ }^{\circ} \mathrm{C}\right)\end{array}$ & $\mathbf{p H}$ & $\begin{array}{l}\text { Cond. } \\
(\mu S / \mathrm{cm})\end{array}$ \\
\hline & & Whychus Creek & & & & & \\
\hline \multirow[t]{6}{*}{44.288010} & -121.543908 & at Sisters Gage & 963 & $09 / 22 / 2006$ & 4.9 & 6.96 & \\
\hline & & & & $11 / 16 / 2006$ & 2.3 & 6.76 & 20.4 \\
\hline & & & & $04 / 07 / 2007$ & 10.8 & 7.24 & 27.1 \\
\hline & & & & $06 / 25 / 2007$ & 6.1 & 6.54 & 14.0 \\
\hline & & & & $09 / 21 / 2007$ & 5.2 & 6.86 & 18.0 \\
\hline & & & & $01 / 24 / 2008$ & 0.0 & 7.49 & 18.0 \\
\hline 44.287522 & -121.514296 & at Reed Ditch & 945 & $09 / 22 / 2006$ & 9.3 & 6.55 & \\
\hline \multirow[t]{4}{*}{44.295307} & -121.507243 & above Chester Springs & 932 & $04 / 07 / 2007$ & 8.3 & 7.07 & 27.7 \\
\hline & & & 932 & $06 / 25 / 2007$ & 7.7 & 6.86 & 16.0 \\
\hline & & & & $09 / 21 / 2007$ & 5.5 & 6.81 & 19.0 \\
\hline & & & & $01 / 24 / 2008$ & 0.0 & 6.93 & 15.0 \\
\hline \multirow[t]{5}{*}{44.307020} & -121.510378 & below Frank Springs & 925 & $11 / 16 / 2006$ & 3.9 & 6.35 & 29.5 \\
\hline & & & & $04 / 07 / 2007$ & 8.5 & 7.13 & 35.8 \\
\hline & & & & $06 / 25 / 2007$ & 9.9 & 7.43 & 38.0 \\
\hline & & & & $09 / 21 / 2007$ & 7.8 & 7.43 & 33.0 \\
\hline & & & & $01 / 24 / 2008$ & 0.9 & & 28.0 \\
\hline \multirow[t]{5}{*}{44.318463} & -121.515250 & at Camp Polk Rd. & 908 & $11 / 16 / 2006$ & 3.1 & 6.59 & 25.0 \\
\hline & & & & $04 / 07 / 2007$ & 9.5 & 7.15 & 36.9 \\
\hline & & & & $06 / 25 / 2007$ & 15.2 & 8.37 & 37.0 \\
\hline & & & & $09 / 21 / 2007$ & 10.1 & 7.96 & 33.0 \\
\hline & & & & $01 / 24 / 2008$ & 0.0 & 7.38 & 28.0 \\
\hline \multirow[t]{4}{*}{44.325805} & -121.502531 & at DRC Gage & 895 & $09 / 22 / 2006$ & 10.7 & 8.00 & \\
\hline & & & & $06 / 25 / 2007$ & 16.6 & 8.17 & 37.0 \\
\hline & & & & $09 / 21 / 2007$ & 12.1 & 8.03 & 33.0 \\
\hline & & & & $01 / 24 / 2008$ & 0.0 & 7.29 & 28.0 \\
\hline & & Indian Ford Creek & & & & & \\
\hline \multirow[t]{4}{*}{44.320296} & -121.538357 & at Camp Polk Rd. & 960 & $09 / 22 / 2006$ & 10.3 & 6.86 & \\
\hline & & & & $11 / 16 / 2006$ & 3.6 & 6.71 & 65.5 \\
\hline & & & & $04 / 07 / 2007$ & 13.2 & 7.24 & 55.4 \\
\hline & & & & $01 / 22 / 2008$ & 0.1 & 6.36 & 44.0 \\
\hline 44.303556 & -121.528976 & at Barclay Dr. & 956 & $11 / 16 / 2006$ & 3.9 & 7.00 & 67.0 \\
\hline 44.356582 & -121.615107 & at Hwy. 20 & 987 & $06 / 25 / 2007$ & 12.9 & 7.59 & 34.0 \\
\hline
\end{tabular}


Table 11. - Continued. Location information and summary of field parameters collected at sampling locations during the current study and previous studies. Blank records indicate the parameter was not measured.

\begin{tabular}{|c|c|c|c|c|c|c|c|}
\hline Latitude & Longitude & Name & $\begin{array}{r}\text { Elev. } \\
(\mathrm{m})\end{array}$ & $\begin{array}{c}\text { Date } \\
\text { (mo/d/yr) }\end{array}$ & $\begin{array}{c}\text { Temp. } \\
\left({ }^{\circ} \mathrm{C}\right)\end{array}$ & $\mathbf{p H}$ & $\begin{array}{l}\text { Cond. } \\
(\mu \mathrm{S} / \mathrm{cm})\end{array}$ \\
\hline \multicolumn{8}{|c|}{ McKinney Butte Springs } \\
\hline \multirow[t]{5}{*}{44.299501} & -121.509843 & Chester & 930 & $11 / 16 / 2006$ & 8.9 & 6.80 & 115.7 \\
\hline & & & & $04 / 07 / 2007$ & 11.0 & 7.46 & 106.3 \\
\hline & & & & $06 / 25 / 2007$ & 9.9 & 7.43 & 72.0 \\
\hline & & & & 09/21/2007 & 9.6 & 6.93 & 65.0 \\
\hline & & & & $01 / 24 / 2008$ & 8.9 & 7.12 & 65.0 \\
\hline \multirow[t]{6}{*}{44.303469} & -121.510194 & Frank & 929 & $11 / 16 / 2006$ & 8.4 & 6.96 & 111.0 \\
\hline & & & & $04 / 07 / 2007$ & 9.6 & 7.43 & 103.9 \\
\hline & & & & $06 / 25 / 2007$ & 8.9 & 7.12 & 61.0 \\
\hline & & & & 08/29/2007 & 8.9 & 7.07 & 63.0 \\
\hline & & & & $09 / 21 / 2007$ & 8.9 & 6.99 & 63.0 \\
\hline & & & & $01 / 24 / 2008$ & 8.9 & & 62.0 \\
\hline & & Camp Polk Springs & & & & & \\
\hline 44.314701 & -121.514641 & Anderson & 921* & $09 / 22 / 2006$ & 7.9 & 7.24 & \\
\hline 44.316128 & -121.514667 & Anderson at Whychus Creek & 914* & $09 / 22 / 2006$ & 8.6 & 6.80 & \\
\hline \multirow[t]{5}{*}{44.318916} & -121.517512 & Camp Polk Springhouse & $924 *$ & $11 / 16 / 2006$ & 8.6 & 6.26 & 125.0 \\
\hline & & & & $04 / 07 / 2007$ & 10.2 & & 108.0 \\
\hline & & & & $06 / 25 / 2007$ & 9.2 & 7.53 & 66.0 \\
\hline & & & & 09/21/2007 & 9.3 & 6.62 & 86.0 \\
\hline & & & & $01 / 24 / 2008$ & 9.0 & 6.70 & 74.0 \\
\hline & & Other Springs & & & & & \\
\hline 44.367103 & -121.668697 & Paulina & 1024 & 08/29/2007 & 4.3 & 6.80 & 30.0 \\
\hline 44.441551 & -121.346522 & Alder & 695 & $09 / 20 / 2007$ & 10.5 & 7.80 & 67.0 \\
\hline \multirow[t]{2}{*}{44.434348} & -121.638067 & Metolius & 914 & $01 / 23 / 2008$ & 8.9 & 7.70 & 63.0 \\
\hline & & Previous Studies & & & & & \\
\hline 44.441551 & -121.346522 & Alder Springs (Caldwell, 1998) & 695 & $01 / 19 / 1995$ & 10.5 & 8.00 & 136.0 \\
\hline 44.491111 & -121.296944 & Lower Opal Springs (Caldwell, 1998) & 597 & 01/09/1995 & 12.0 & 8.10 & 128.0 \\
\hline 44.367103 & -121.668697 & Paulina Spring (Caldwell, 1998) & 1024 & 01/11/1995 & 4.5 & 7.20 & 60.0 \\
\hline & & Paulina Spring (Ingebritsen, 1988) & & $07 / 26 / 1987$ & & & 30.0 \\
\hline \multirow[t]{6}{*}{44.434348} & -121.638067 & Metolius Spring (Evans, 2004) & 914 & $08 / 05 / 2002$ & 8.7 & 7.71 & 124.0 \\
\hline & & Metolius Spring (Ingebritsen, 1988) & & 09/27/1986 & & & \\
\hline & & Metolius Spring (James, 1999) & & $10 / 18 / 1997$ & 8.3 & 7.60 & 120.2 \\
\hline & & & & 11/01/1997 & 8.1 & 7.60 & 119.5 \\
\hline & & & & 05/30/1998 & 8.3 & 7.50 & 119.5 \\
\hline & & & & $06 / 25 / 1998$ & 8.2 & 7.40 & 120.6 \\
\hline
\end{tabular}




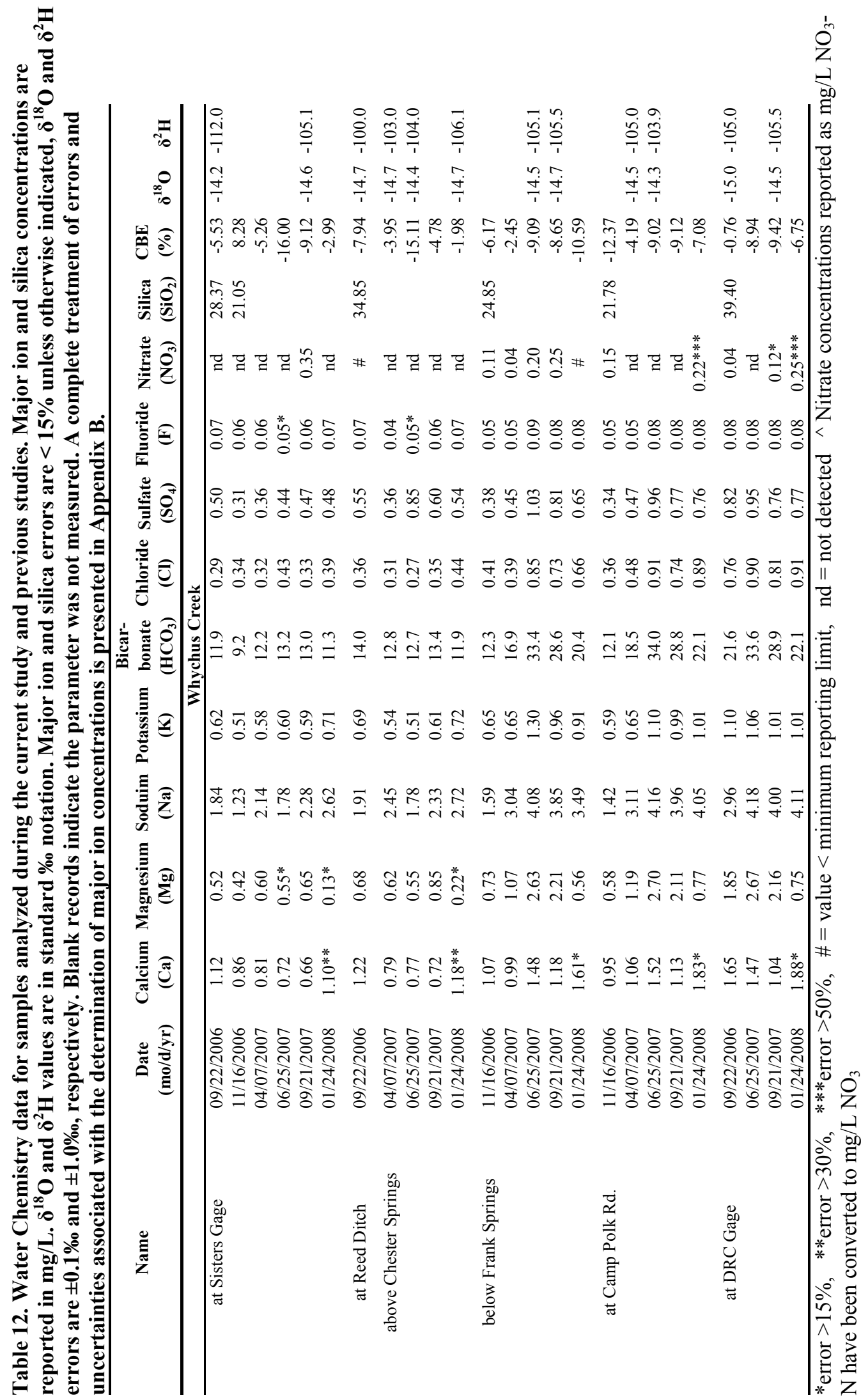




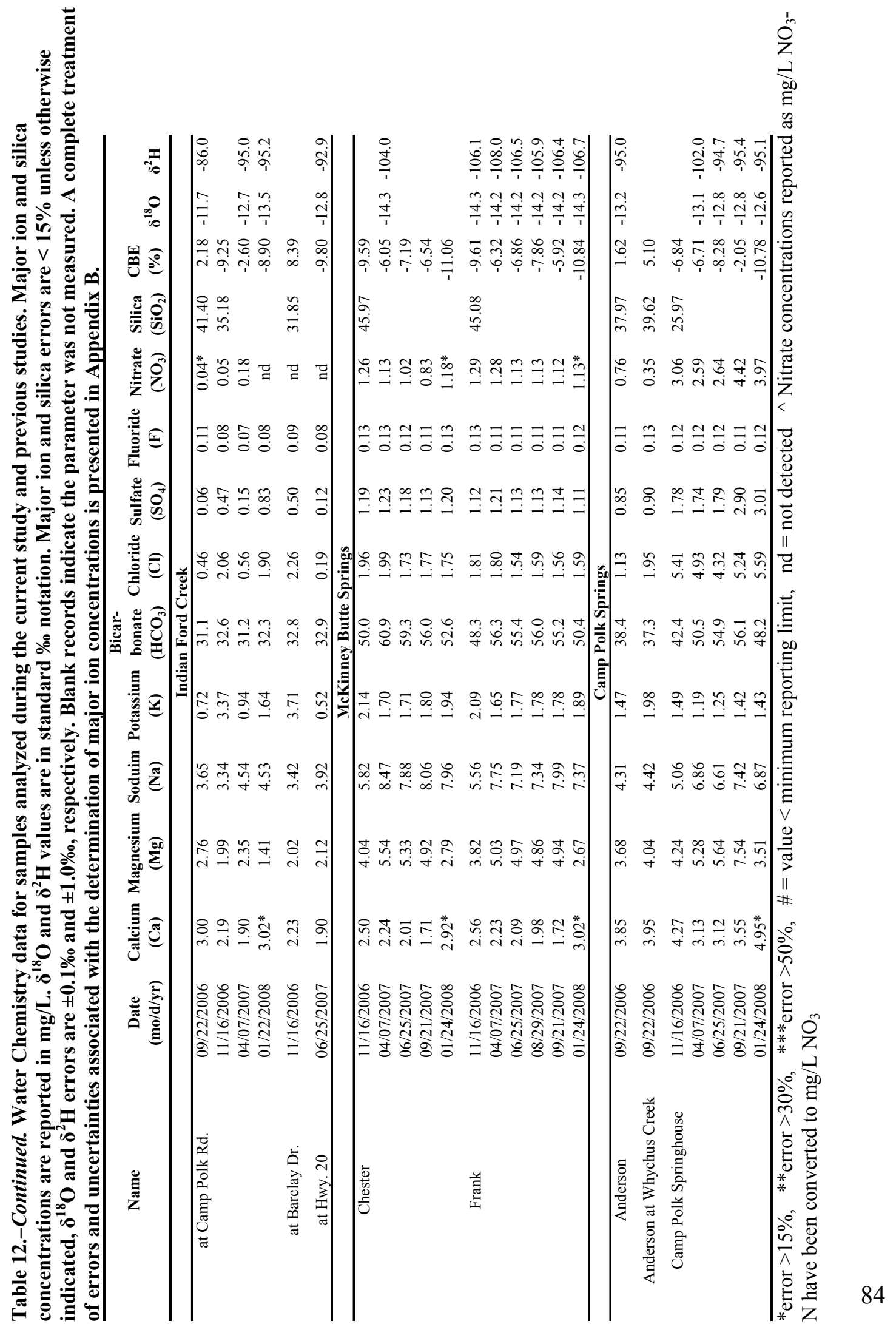




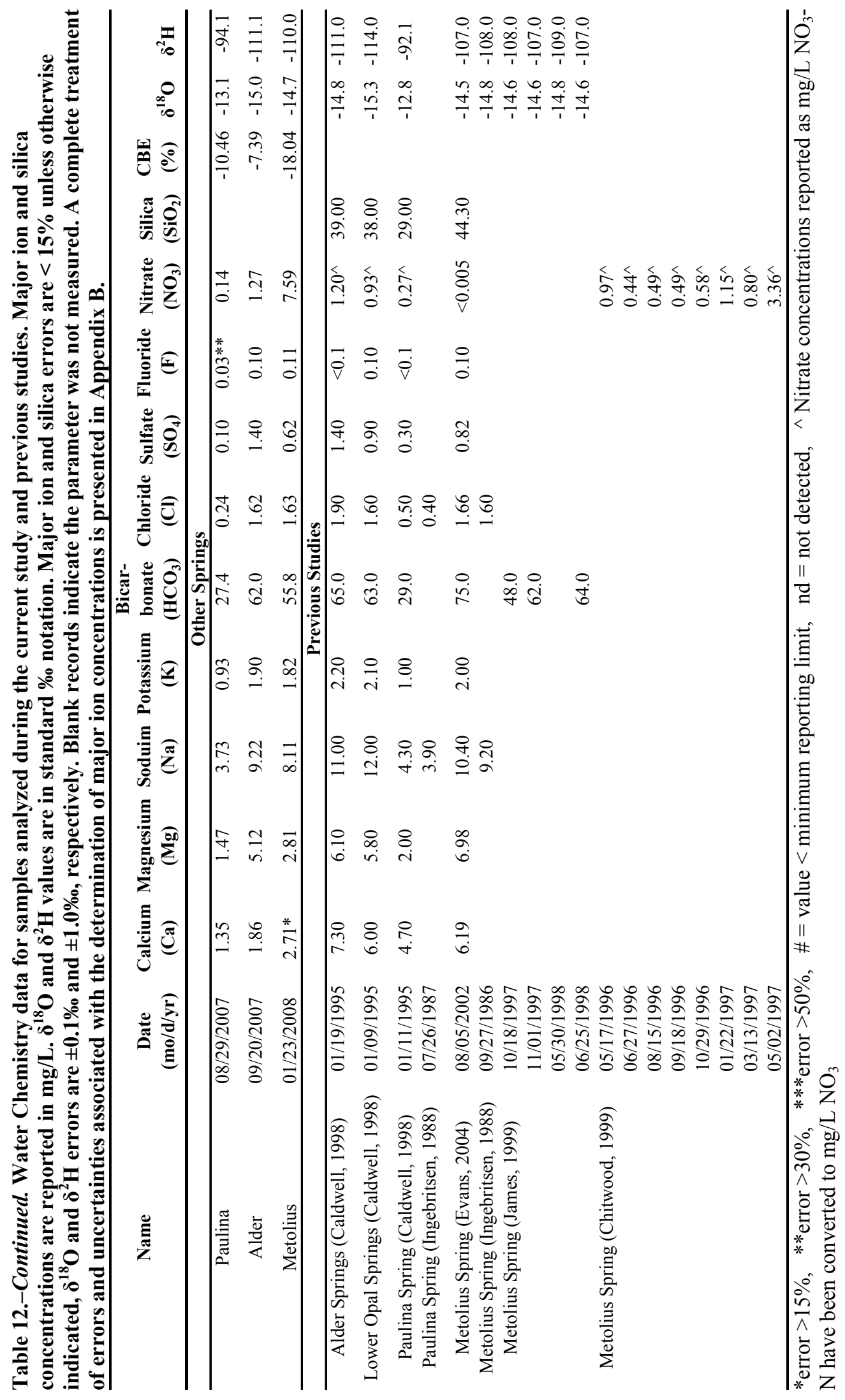




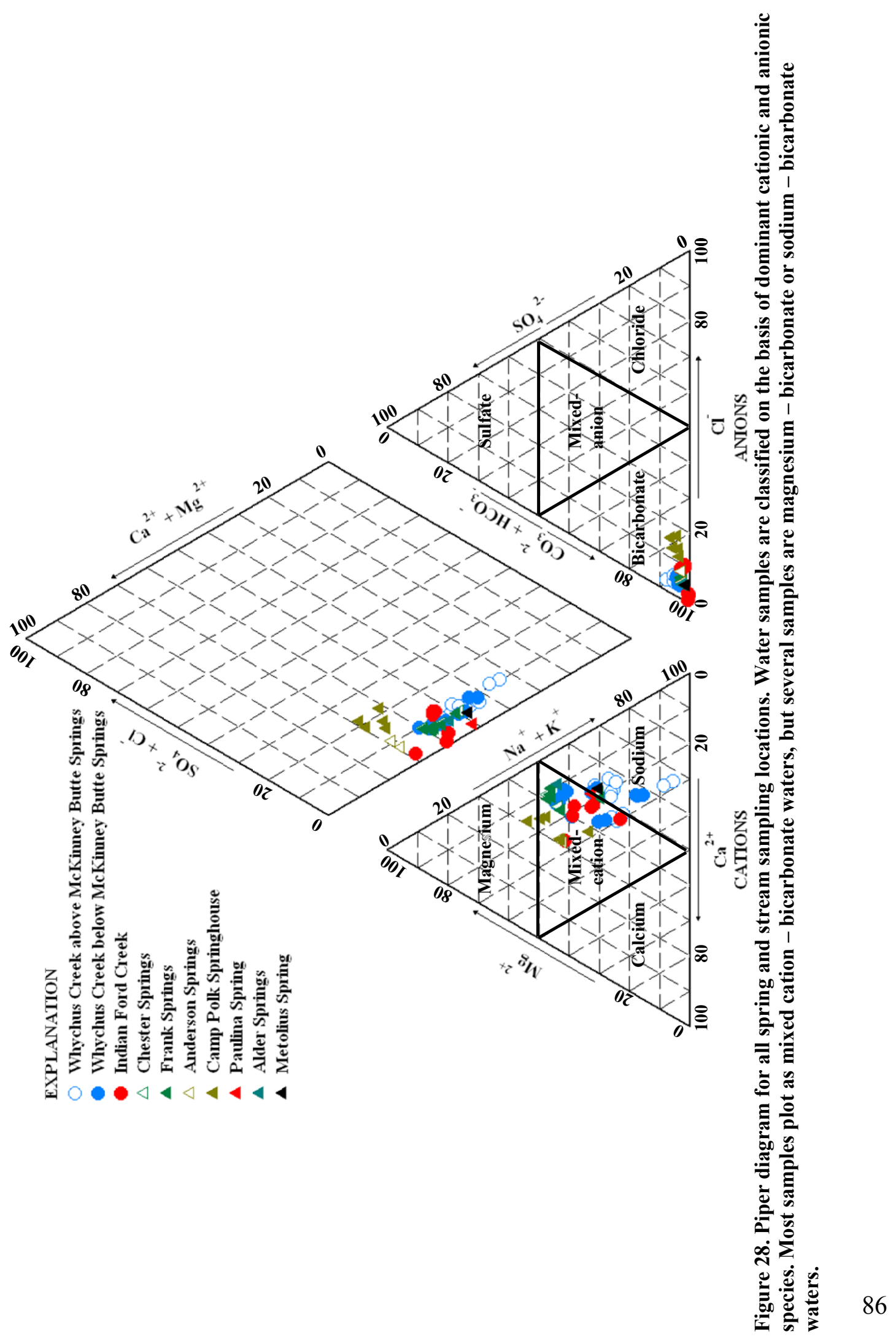


In general, ionic concentrations were higher in spring samples (average total ionic concentration $=72.5 \mathrm{mg} / \mathrm{L}$ ) than in stream samples (average total ionic concentration $=29.5 \mathrm{mg} / \mathrm{L})($ Table 13). Paulina Spring was the exception; its total ionic concentration of $35.4 \mathrm{mg} / \mathrm{L}$ was similar to average concentrations in Whychus (25.9 mg/L) and Indian Ford (44.07 mg/L) creeks. Samples from Whychus Creek above the McKinney Butte Springs had a lower average ion concentration $(17.4 \mathrm{mg} / \mathrm{L})$ than samples below the McKinney Butte Springs $(32.7 \mathrm{mg} / \mathrm{L})$. Similar total ionic concentrations were found in Chester Springs $(76.3 \mathrm{mg} / \mathrm{L})$, Frank Springs $(73.4 \mathrm{mg} / \mathrm{L})$, Camp Polk Springhouse (78.2 mg/L), Alder Springs (84.5 mg/L), and Metolius Spring (81.2 mg/L). The average total ionic concentration in Anderson Springs (54.8 mg/L) was higher than stream samples but lower than all spring samples except Paulina Spring.

Table 13. Total ionic concentration for various site types $(\mathrm{mg} / \mathrm{L})$.

\begin{tabular}{lccr}
\hline \multicolumn{1}{c}{ Sample Type } & \multicolumn{2}{c}{$\begin{array}{c}\text { Standard } \\
\text { Deviation }\end{array}$} & $\begin{array}{c}\text { Number of } \\
\text { Samples }\end{array}$ \\
\hline All Streams & 29.4 & 12.0 & 31 \\
All Springs & 72.5 & 12.1 & 21 \\
Whychus Creek all samples & 25.9 & 10.6 & 25 \\
Whychus Creek above McKinney Butte Springs & 17.4 & 1.7 & 11 \\
Whychus Creek below McKinney Butte Springs & 32.7 & 9.7 & 14 \\
Indian Ford Creek & 44.1 & 2.5 & 6 \\
Chester Springs & 76.3 & 5.7 & 5 \\
Frank Springs & 73.4 & 4.3 & 6 \\
Anderson Springs & 54.8 & 0.3 & 2 \\
Camp Polk Springhouse & 78.2 & 7.5 & 1 \\
Paulina Spring & 35.4 & & 1 \\
Alder Springs & 84.5 & & 1 \\
Metolius Spring & 81.2 & &
\end{tabular}


Although the general geochemical characteristics of streams and springs analyzed during this study are quite similar (all samples were classified as mixed cation-, sodium- , or magnesium- bicarbonate waters), distinct differences emerge when individual ions and ion ratios are compared. Schoeller and simple variation diagrams aided in discerning differences between samples. Schoeller diagrams, consisting of ionic concentrations (expressed in milliequivalents per liter) plotted on a logarithmic scale allowed comparison of multiple ionic species from multiple samples on one chart. Differences identified on Schoeller diagrams were then more closely examined on variation diagrams.

Concentrations of $\mathrm{Ca}, \mathrm{Mg}, \mathrm{Na}, \mathrm{Cl}, \mathrm{SO}_{4}$, and $\mathrm{HCO}_{3}$ for all samples are displayed on a Schoeller diagram in Figure 29. $\mathrm{Ca}, \mathrm{Na}$ and $\mathrm{HCO}_{3}$ concentrations plot in a relatively narrow range - less than one order of magnitude separates minimum and maximum concentrations $\left(\mathrm{Ca}_{\max } / \mathrm{Ca}_{\min }=7.4, \mathrm{Na}_{\max } / \mathrm{Na}_{\min }=7.5\right.$, $\left.\mathrm{HCO}_{3 \max } / \mathrm{HCO}_{3 \min }=6.7\right)$ - while $\mathrm{Mg}, \mathrm{Cl}$, and $\mathrm{SO}_{4}$ have a wider range of concentrations $\left(\mathrm{Mg}_{\max } / \mathrm{Mg}_{\min }=58.0, \mathrm{Cl}_{\max } / \mathrm{Cl}_{\min }=28.9, \mathrm{SO}_{4 \max } / \mathrm{SO}_{4 \min }=50.8\right)$. Also noticeable on Figure 29 are concentration differences among spring samples, especially between $\mathrm{Cl}$ and $\mathrm{SO}_{4}$. These concentration differences are more easily seen when average concentrations for each spring are plotted (Figure 30). Concentrations are lowest in Paulina Spring. High $\mathrm{Cl}$ and $\mathrm{SO}_{4}$ concentrations in Camp Polk Springhouse distinguish it from the McKinney Butte Springs, Alder Springs, and Metolius Spring, which all have similar concentrations of $\mathrm{Cl}$ and $\mathrm{SO}_{4}$. The low $\mathrm{Mg}$ concentration in Metolius Spring $(0.234 \mathrm{meq} / \mathrm{L})$ is comparable to $\mathrm{Mg}$ concentrations 
in Chester Springs ( $0.232 \mathrm{meq} / \mathrm{L})$, and Frank Springs ( $0.225 \mathrm{meq} / \mathrm{L})$ sampled during the same time of year (January 2008).

Differences in concentrations of $\mathrm{Cl}, \mathrm{NO}_{3}$, and $\mathrm{SO}_{4}$, are seen more easily on the following variation diagrams: $\mathrm{Cl}$ vs $\mathrm{NO}_{3}$ (Figure 31 ), $\mathrm{Cl}$ vs $\mathrm{SO}_{4}$ (Figure 32), and $\mathrm{Cl}$ vs $\mathrm{Na}$ (Figure 33). Data for samples from Metolius Spring, Paulina Spring, Alder Spring, and Lower Opal Spring collected during previous studies are shown for comparison. Field parameters for samples collected during previous studies are presented in Table 11 and major element chemistry and stable isotope data are shown in Table 12.

The most obvious observations are the elevated $\mathrm{Cl}$ concentrations in Camp Polk Springhouse (Figures 31, 32, and 33), and the high concentration of $\mathrm{NO}_{3}$ in the Metolius Spring sample from the current study (Figure 31). The Metolius Spring sample from Evans et al. (2004) contains $<0.005 \mathrm{mg} / \mathrm{L} \mathrm{NO}_{3}$. Concentrations of $\mathrm{SO}_{4}$ and $\mathrm{NO}_{3}$ in Camp Polk Springhouse are also elevated relative to other springs and streams (with the exception of $\mathrm{NO}_{3}$ in Metolius Spring) (Figures 31 and 32) $\mathrm{NO}_{3}$ concentrations in samples from Whychus and Indian Ford creeks were typically very low, and several samples from both creeks did not contain measureable $\mathrm{NO}_{3}$. Camp Polk Springhouse displays a chloride "shift" in Figure 33, where Na concentrations in Camp Polk Springhouse are similar to concentrations in the McKinney Butte Springs and are slightly lower than concentrations in Metolius Spring, Alder Springs and Lower Opal Springs, but $\mathrm{Cl}$ concentrations in Camp Polk Springhouse are considerably larger than concentrations in any of the other springs. 


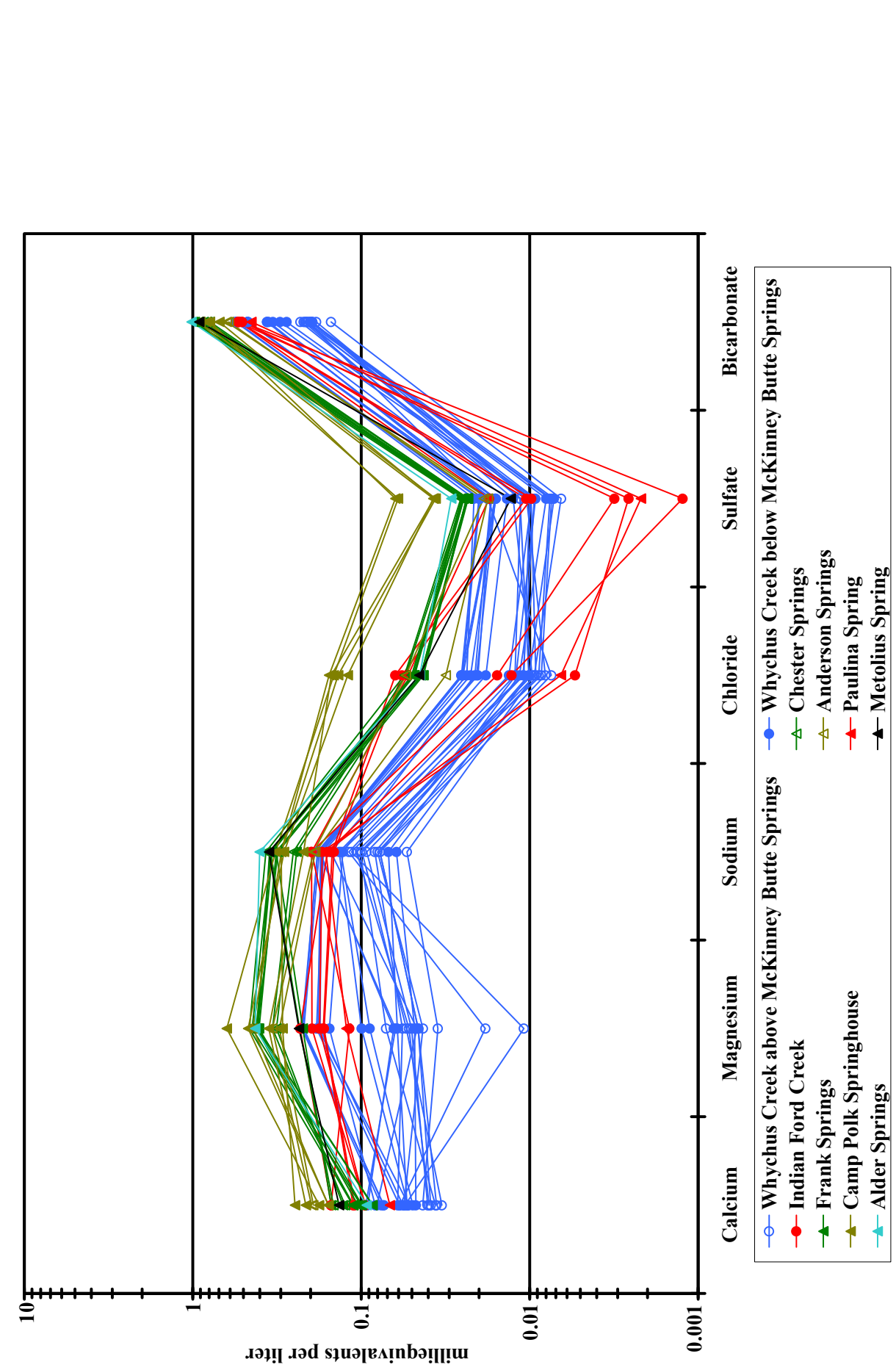

है

$\Xi \Xi$

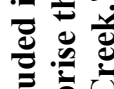

氞 을

일

药

音

कै

或

已 :

:

है

递苋

를

递

ह

妾

\&

产 营

클

$\stackrel{3}{0}$

园

을

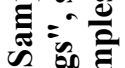

$\dot{s} \Xi$

की

氧 =

㲾

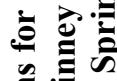

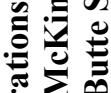

政

है है

¿

氜已

ลิํㅡㄹ

¿

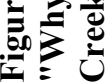




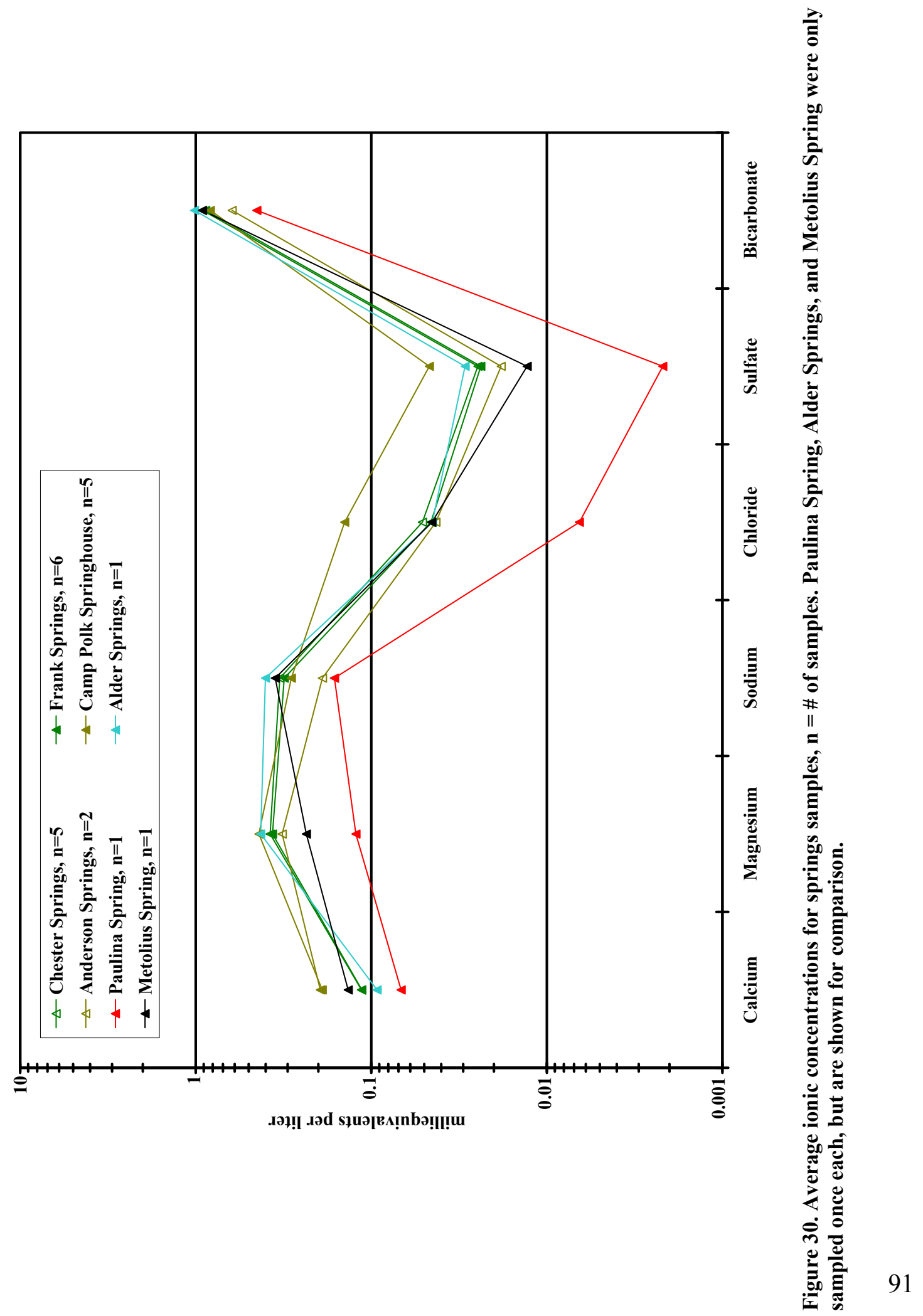




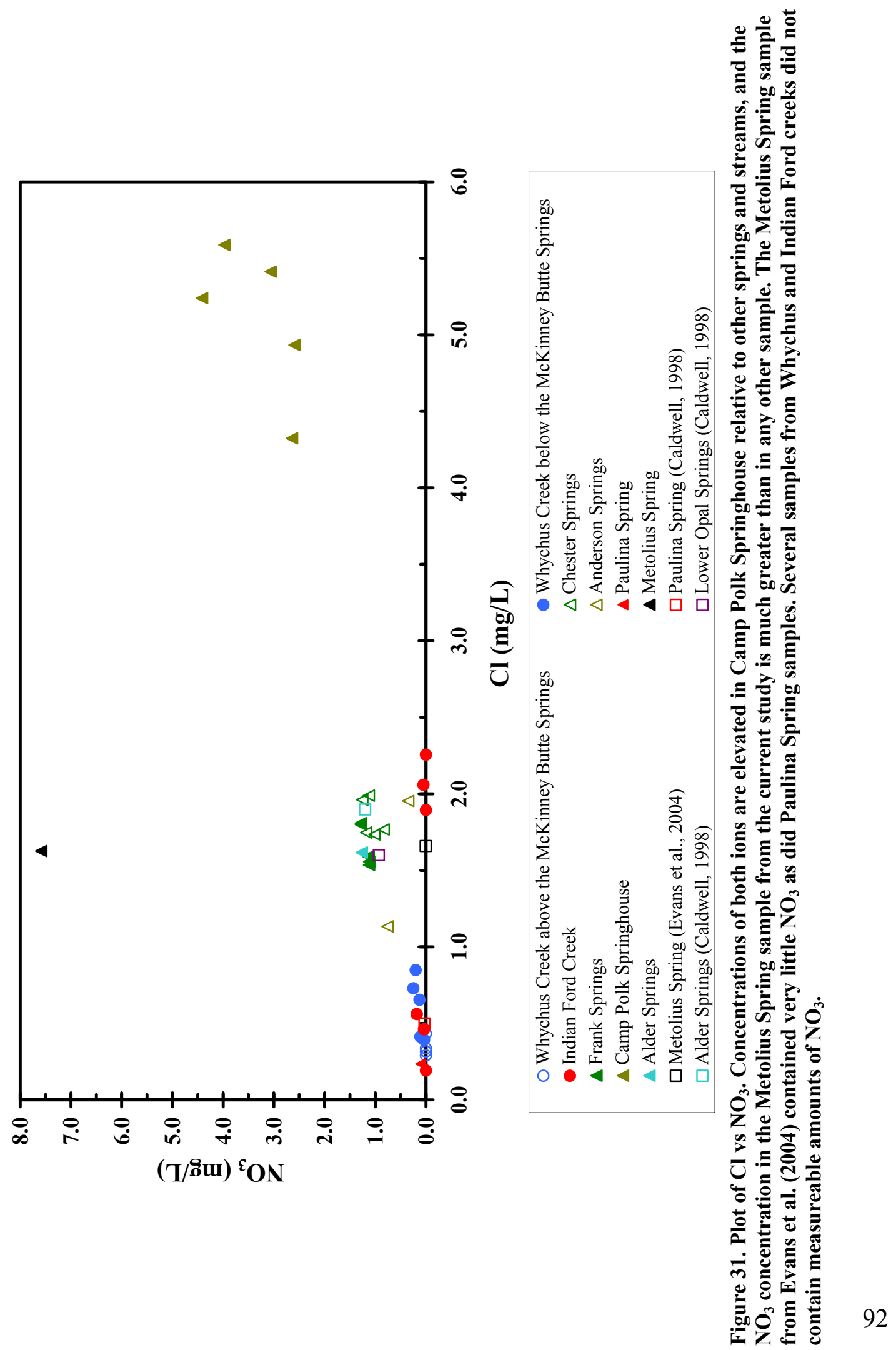




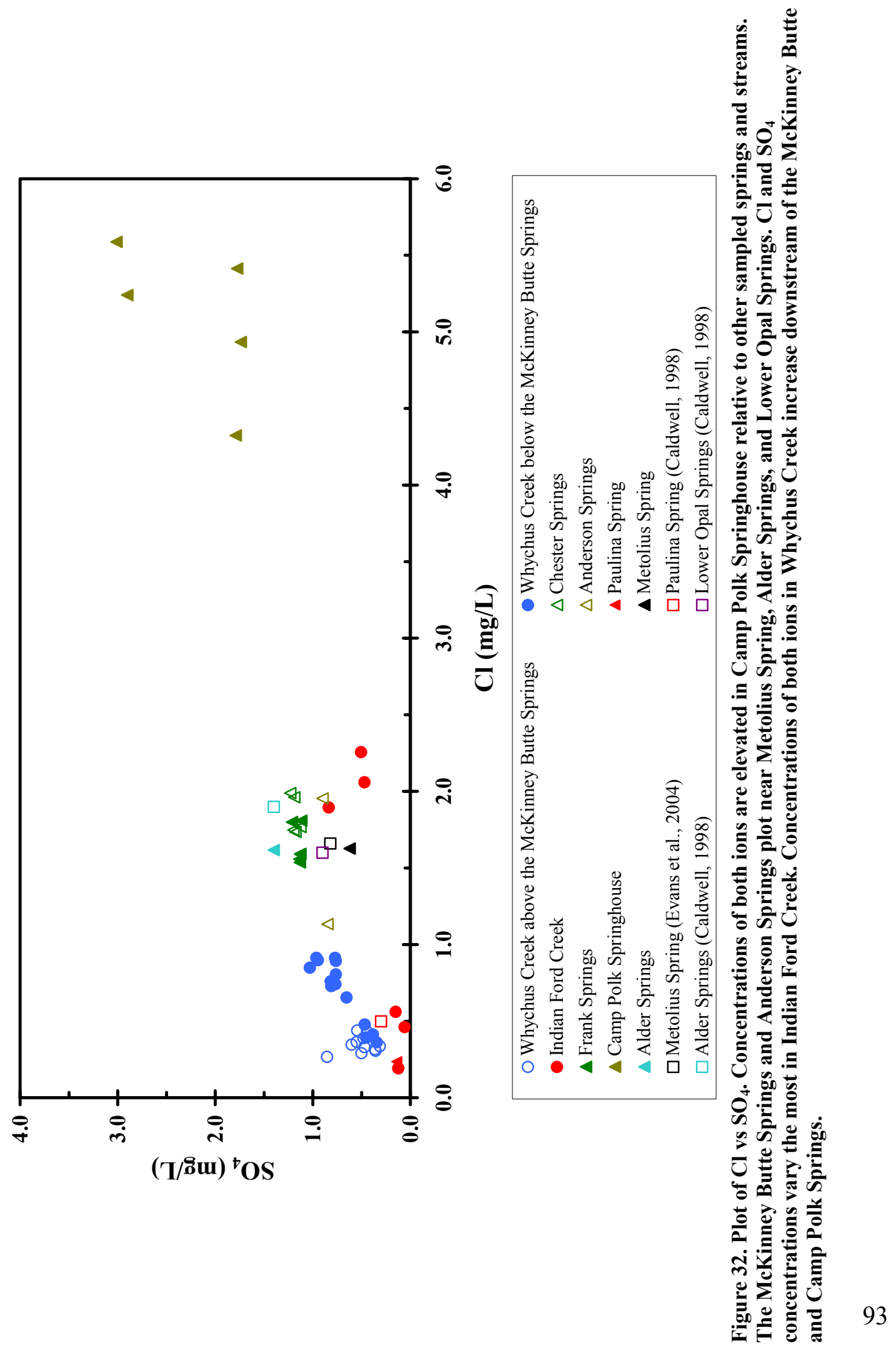



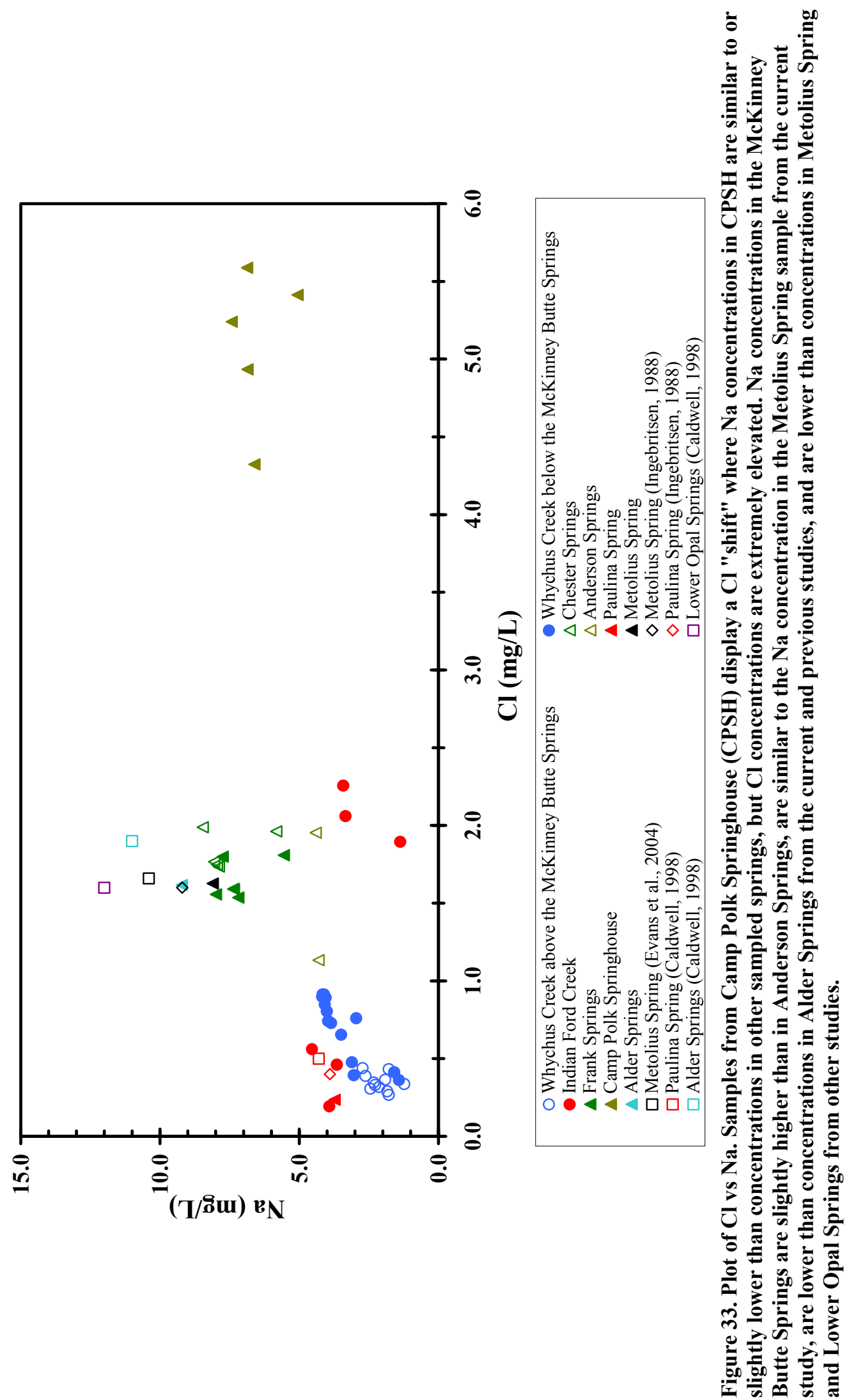


\section{Stable Isotopes}

A total of 31 samples (12 from Whychus Creek, 4 from Indian Ford Creek, 7 from the McKinney Butte Springs (6 from Frank Springs and 1 from Chester Springs), 5 from the Camp Polk Springs (4 from Camp Polk Springhouse and 1 Anderson Springs), and one each from Paulina Spring, Alder Springs, and Metolius Spring) were analyzed for ${ }^{2} \mathrm{H}$ and ${ }^{18} \mathrm{O}$ concentrations and are reported as delta values (\%o) relative to Vienna Standard Mean Ocean Water (VSMOW) (Table 12). Samples plot on a line given by $\delta^{2} \mathrm{H}=6.3 \delta^{18} \mathrm{O}-14.0$, which has a lower slope than the Global Meteoric Water Line (GMWL) defined as $\delta^{2} \mathrm{H}=\delta^{18} \mathrm{O}+10$ by Craig (1961) (Figure 34). However, several samples plot above the GMWL. The measured isotopic variation in all samples ranges from -86.0 to $-112.0 \%$ and -11.7 to $-15.0 \%$ for $\delta^{2} \mathrm{H}$ and $\delta^{18} \mathrm{O}$, respectively. Indian Ford Creek, Paulina Spring, and the Camp Polk Springs are isotopically enriched relative to Whychus Creek, the McKinney Butte Springs, Alder

Springs, and Metolius Spring. $\delta^{2} \mathrm{H}$ and $\delta^{18} \mathrm{O}$ delta values ranged from -86.0 to $-95.0 \%$ and -11.7 to $-13.5 \%$ in Indian Ford Creek, and from -94.7 to $-102.0 \%$ and -12.6 to $13.2 \%$ in the Camp Polk Springs. Ratios in Paulina Spring were $-13.1 \%$ for $\delta^{18} \mathrm{O}$ and $-94.1 \%$ for $\delta^{2} \mathrm{H} . \delta^{2} \mathrm{H}$ and $\delta^{18} \mathrm{O}$ delta values ranged from -112.0 to $-100.0 \%$ and -14.2 to $-15.0 \%$ in Whychus Creek, and -104.0 to $-108.0 \%$ and -14.2 to $-14.3 \%$ in the McKinney Butte Springs. Alder Springs and Metolius Spring were most depleted in $\delta^{2} \mathrm{H}$ and $\delta^{18} \mathrm{O}$ with delta values of $-15.0 \%$ and $-111.1 \%$ in Alder Springs and $-14.7 \%$ and $-110.0 \%$ in Metolius Spring for $\delta^{2} \mathrm{H}$ and $\delta^{18} \mathrm{O}$, respectively. 
Isotopic concentrations from previous studies by Ingebritsen et al. (1988), Caldwell (1998), and James (1999) are shown in Figure 35. Local Meteoric Water Lines (LMWLs) for each study are also shown. LMWLs for Ingebritsen (1988) and James (1999) have lower slopes than the GMWL and are similar to the LMWL from the current study, while samples from Caldwell (1998) plot on a line with the same slope as the GMWL (Figure 35). 


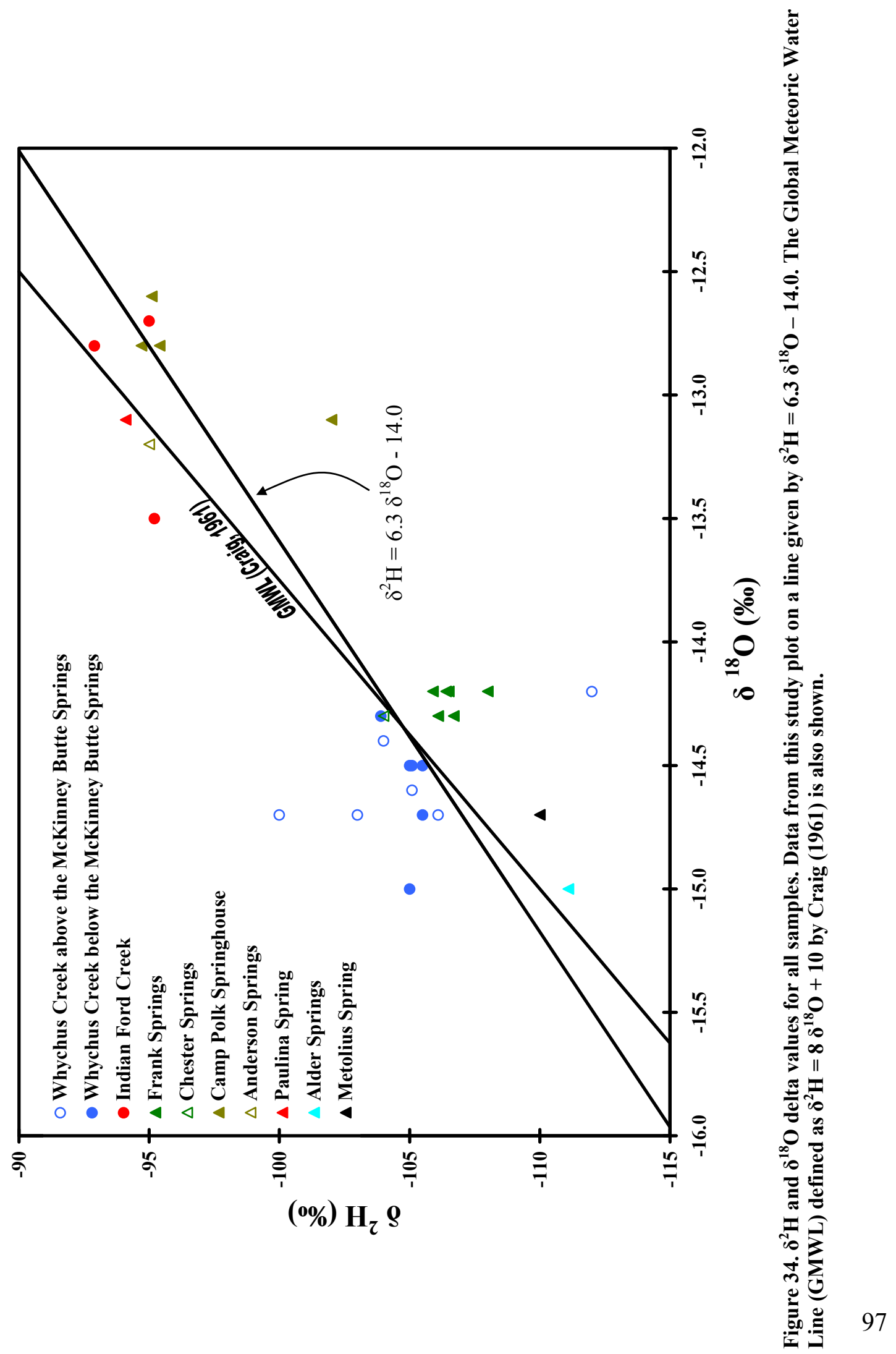




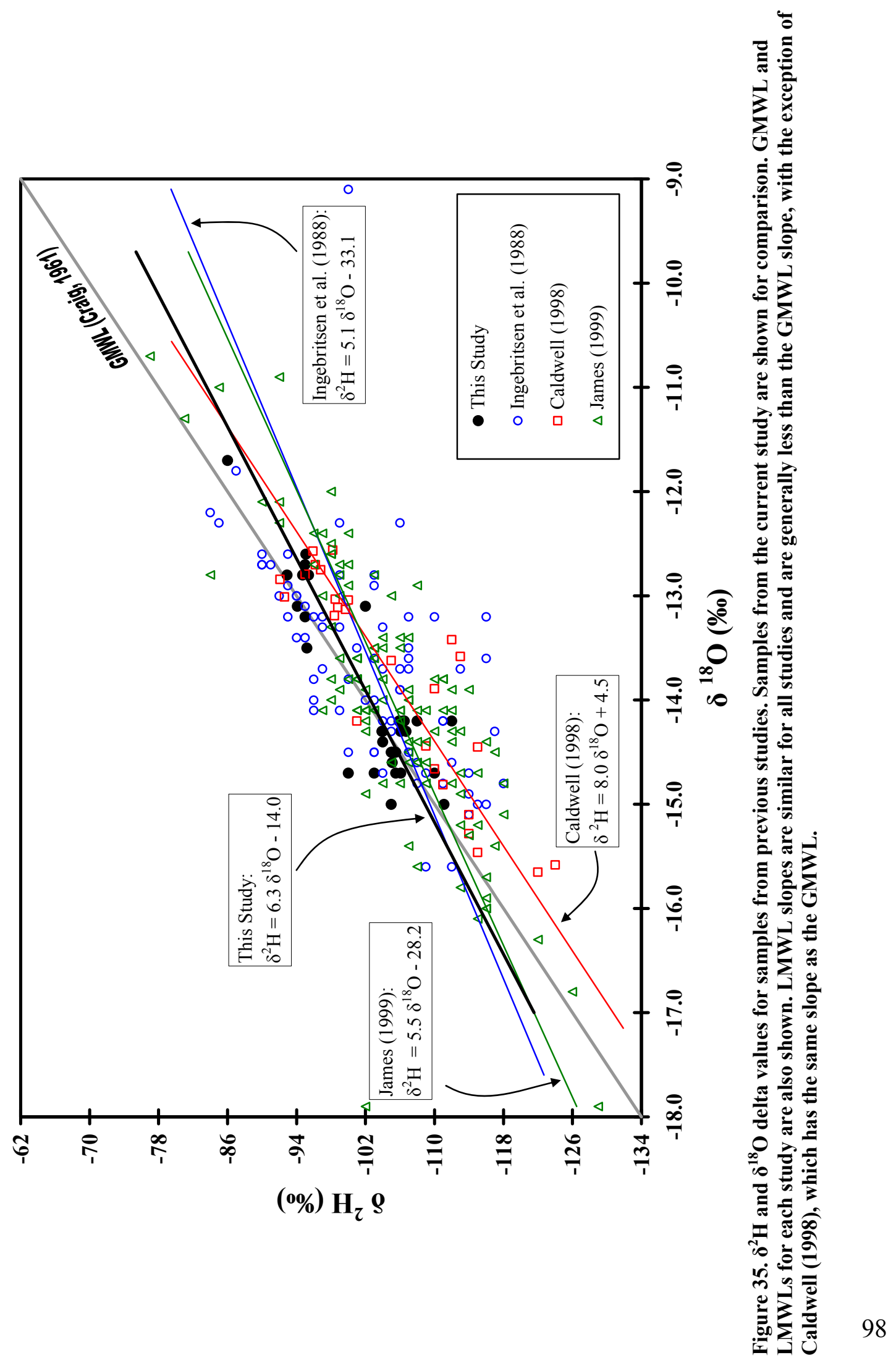




\section{Temperature}

Temperature data collected every 10 minutes from several locations in Whychus Creek and in the McKinney Butte Springs from 08/30/2007 to 10/15/2007 along with measurements collected at study area streams and springs during water sampling events are presented below. Temperature data collected every two hours in the Lamb Well (DESC 54659) from 01/11/2007 to 10/31/2007 are also presented.

Temperature variations are generally larger in creeks than in springs. Standard deviation from mean values range from 3.7 to $7.0^{\circ} \mathrm{C}$ in Whychus and Indian Ford creeks and from 0.4 to $0.9^{\circ} \mathrm{C}$ in the McKinney Butte and Camp Polk springs (Table 14). Of the springs, the lowest temperature was measured in Paulina Spring $\left(4.3{ }^{\circ} \mathrm{C}\right)$ and the highest was measured in Alder Springs $\left(10.5^{\circ} \mathrm{C}\right)$. Chester Springs has a higher mean temperature and a larger standard deviation $\left(9.7^{\circ} \mathrm{C}, \sigma=0.9^{\circ} \mathrm{C}\right)$ than the other springs on McKinney Butte; the mean temperature and standard deviation in Frank Springs and Camp Polk Springhouse are $8.9^{\circ} \mathrm{C}, \sigma=0.4{ }^{\circ} \mathrm{C}$ and $9.3{ }^{\circ} \mathrm{C}, \sigma=0.6^{\circ} \mathrm{C}$, respectively. The temperature in both Metolius Spring and Frank Springs in January 2008 was $8.9^{\circ} \mathrm{C}$.

Temperature measurements collected every 10 minutes from 08/30/2007 to 10/15/2007 above Chester Springs and below Frank Springs on Whychus Creek, and in Frank Springs and Chester Springs are shown along with daily minimum and maximum air temperatures recorded in Sisters in Figure 36. The temperature variation at any location in Whychus Creek generally follows that of the local air temperature, 
exhibiting diurnal fluctuations related to daily high and low air temperatures, although variation in the creek is not as pronounced as air temperature differences (Figure 36). The magnitude of temperature fluctuations in Whychus Creek below Frank Springs site is less than those above Chester Springs (Figure 36).

Water temperatures recorded in the Lamb Well (DESC 54659) are displayed with temperatures from McKinney Butte Springs in Figure 37. Average temperatures in Frank and Chester springs during the period of continuous monitoring was $9.04{ }^{\circ} \mathrm{C}$ $\left(\sigma=0.04{ }^{\circ} \mathrm{C}\right)$ and $9.42{ }^{\circ} \mathrm{C}\left(\sigma=0.15^{\circ} \mathrm{C}\right)$, respectively. The average temperature in the Lamb Well during same period was $9.20^{\circ} \mathrm{C}\left(\sigma=0.01{ }^{\circ} \mathrm{C}\right)$. Temperatures in the well are similar to, but more stable than, temperatures in the springs. The "angular" appearance of the temperature data for the McKinney Butte Springs shown in Figure 37 is an artifact of the resolution limits $\left(0.15^{\circ} \mathrm{C}\right)$ of the temperature probes used in the springs. 


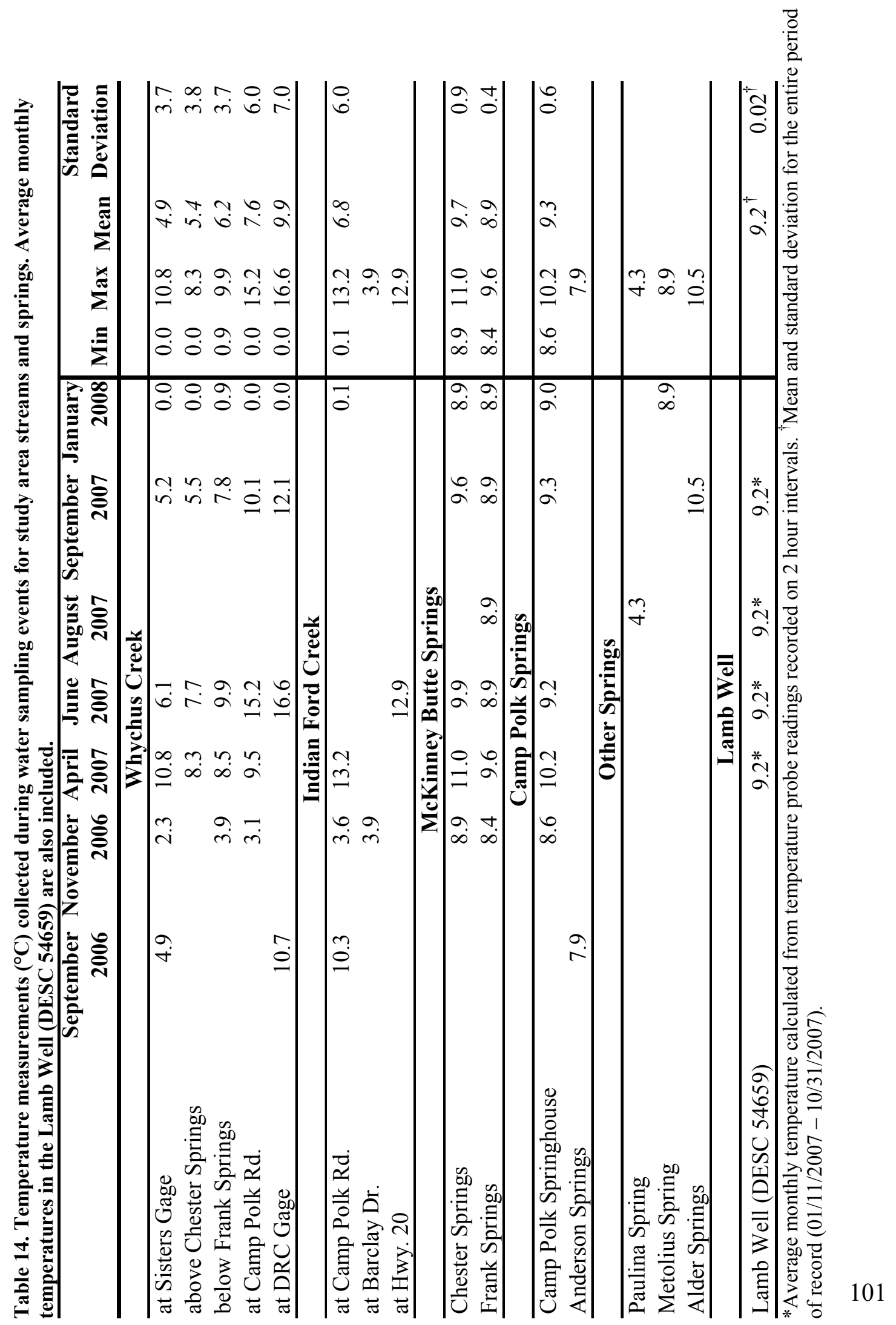




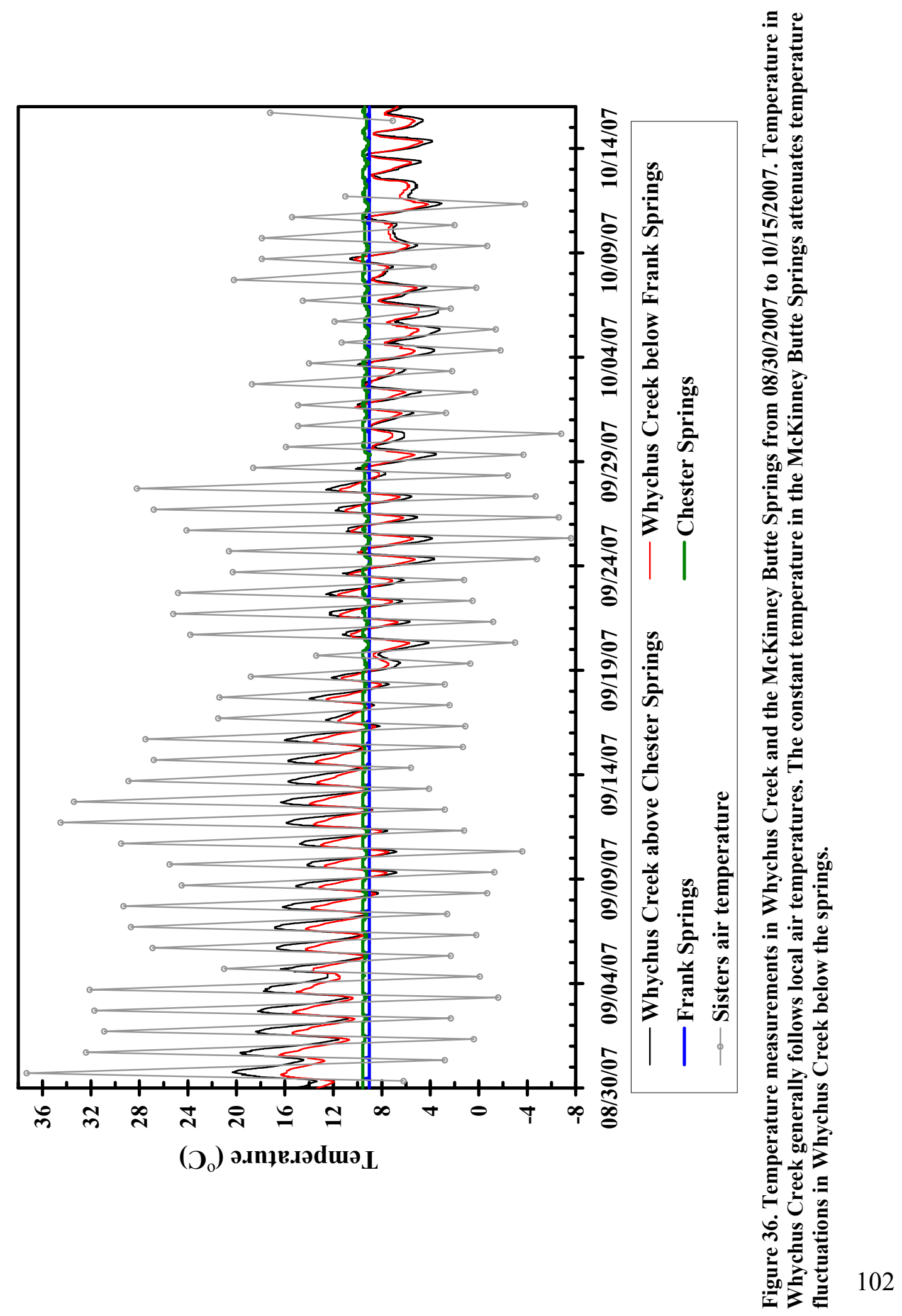




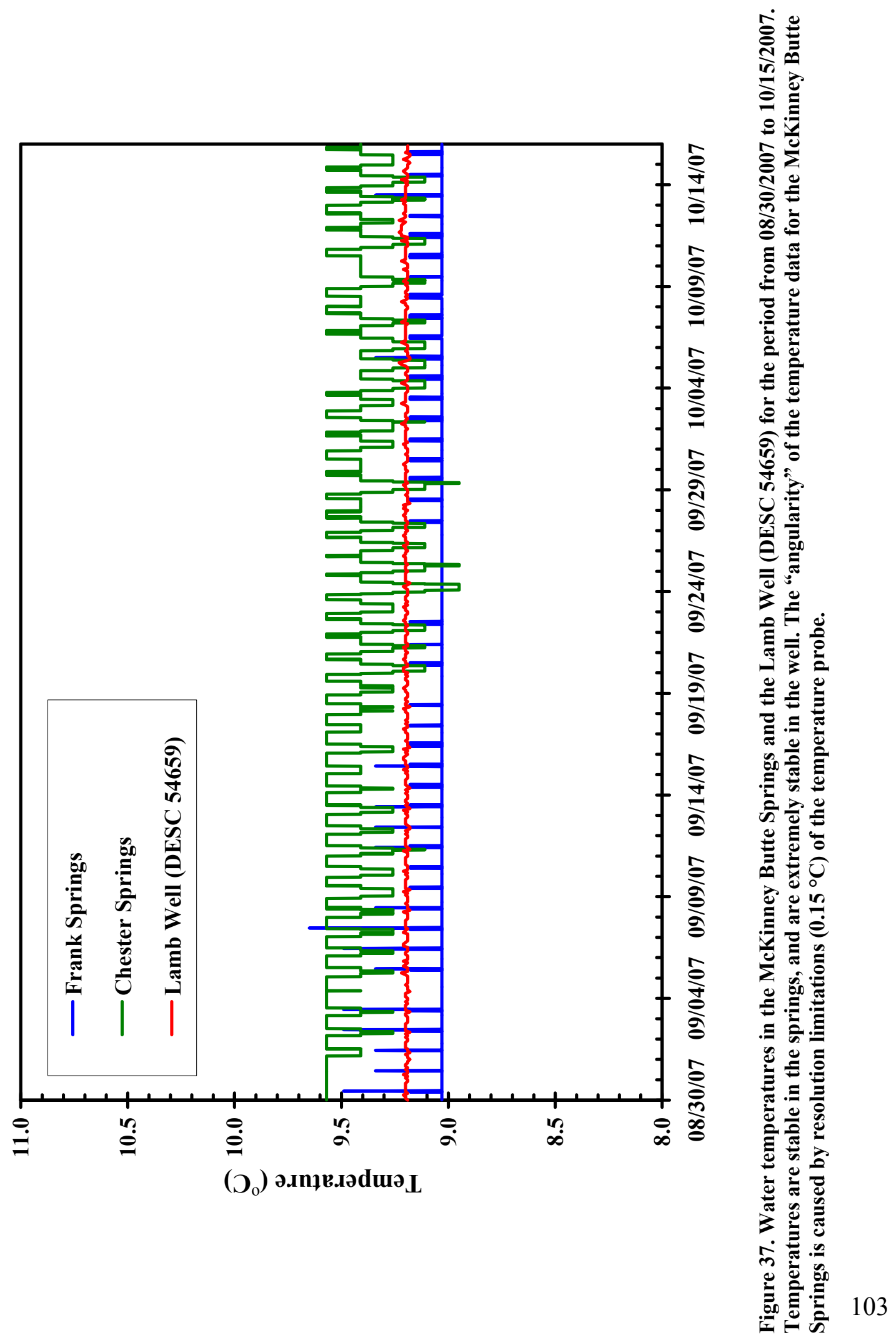




\section{Chapter 6 - Discussion}

\section{Camp Polk Springs Discharge}

The Camp Polk Springs are located in Reach 3 of Whychus Creek as described in Chapter 4 (Figure 13, locations shown on Figure 2). Measured discharge along Reach 3 increased on 04/16/2007,06/25/2007, and 01/30/2008, and decreased on 09/21/2007 (Figure 16). However, the gains and losses were less than calculated errors and therefore may not represent actual gains or losses. Despite measurement uncertainties, discharge from the Camp Polk Springs provides a logical explanation for increases in discharge along reach 3 during late spring, early summer, and winter. As will be shown in the following sections, the Camp Polk Springs discharge shallow, local-scale groundwater. Springs that are supplied by shallow groundwater tend to have greater seasonal fluctuations in discharge than those that discharge groundwater that has circulated deeper in the flow system. Expected discharge from the Camp Polk Springs would be larger during times of greater recharge (late fall and winter due to precipitation, and spring and early summer due to snowmelt) and would be lower during times of less recharge (late summer).

\section{McKinney Butte Springs Discharge}

Estimates of discharge from the McKinney Butte Springs presented in the Physical Hydrogeology chapter (Chapter 4) were determined via seepage runs on Whychus Creek. One limitation of estimating discharge from springs using seepage 
runs is that the differences measured at higher stream flow conditions represent a significantly smaller percentage of total flow and, hence, are subject to greater error. For example, on $01 / 30 / 2008$, stream discharges of $1.648 \mathrm{~m}^{3} / \mathrm{s}$ and $1.849 \mathrm{~m}^{3} / \mathrm{s}$ were measured at Whychus Creek above Chester Springs and at Whychus Creek below Frank Springs, respectively. Propagation of the calculated errors (0.089 and 0.091 $\mathrm{m}^{3} / \mathrm{s}$; Table 10) results in an error of $0.132 \mathrm{~m}^{3} / \mathrm{s}$ for a total difference (calculated discharge from springs) of $0.201 \mathrm{~m}^{3} / \mathrm{s}$ (i.e., $66 \%$ uncertainty).

In an attempt to better constrain discharge estimates for the McKinney Butte Springs, two simple mixing models, one using electrical conductivity (EC) and one using temperature data from Whychus Creek and the McKinney Butte Springs were employed. The models assume that EC and temperature contributions to Whychus Creek from the McKinney Butte Springs are proportional to the discharge contribution. Also assumed is that EC and temperature measured in Frank Springs is representative of the entire McKinney Butte Springs complex. Equation 1 was used to calculate the fraction of EC in Whychus Creek provided by the McKinney Butte Springs:

$$
f E C_{M S}=\frac{\left(E C_{B F}-E C_{A C}\right)}{\left(E C_{M S}-E C_{A C}\right)}
$$

where $f E C_{M S}$ is the fraction of the EC measured in Whychus Creek that was provided by the McKinney Butte Springs, $E C_{B F}$ and $E C_{A C}$ are the EC values in Whychus Creek below Frank Springs and above Chester Springs $(\mu \mathrm{S} / \mathrm{cm})$, and $E C_{M S}$ is the EC 
measured in the McKinney Butte Springs $(\mu \mathrm{S} / \mathrm{cm})$. Equation 2 was used to estimate the discharge of the McKinney Butte Springs:

$$
Q_{M S}=f E C_{M S} * Q_{W C B F}
$$

where $Q_{M S}$ is McKinney Butte Springs discharge $\left(\mathrm{m}^{3} / \mathrm{s}\right)$ and $Q_{W C B F}$ is the measured discharge at the Whychus Creek below Frank Springs seepage run site $\left(\mathrm{m}^{3} / \mathrm{s}\right)$. Equation 2 requires discharge measured during seepage runs and EC measured during water sampling events; consequently, McKinney Butte Springs discharge estimates from EC data were only calculated when seepage runs and water sampling events occurred concurrently (i.e., 06/25/2007 and 09/21/2007). Estimated discharges from the McKinney Butte Springs determined by the EC mixing model were $0.166 \mathrm{~m}^{3} / \mathrm{s}$ on $06 / 25 / 2007$ and $0.171 \mathrm{~m}^{3} / \mathrm{s}$ on $09 / 21 / 2007$ (Table 15).

Uncertainty in the estimates of discharge from the McKinney Butte Springs via the EC mixing model result from two primary sources; 1) error in the measurement of $Q_{W C B F}$, and 2) error in measurements of $E C_{B F}, E C_{A C}$, and $E C_{M S}$. Errors associated with $Q_{W C B F}$ measurements, previously discussed in the Study Design and Methods chapter and presented in the Results section of the Physical Hydrogeology chapter, were 0.04 $\mathrm{m}^{3} / \mathrm{s}$ on $06 / 25 / 2007$, and $0.05 \mathrm{~m}^{3} / \mathrm{s}$ on $09 / 21 / 2007$ (Table 15 ).

Uncertainty in EC measurements can be attributed to accuracy of the EC meter. The accuracy of the EC meter used in this study was the greater value between $\pm 0.5 \%$ of the reading or $\pm 1 \mu \mathrm{S} / \mathrm{cm}$ (YSI, 2002). The amount of error assigned to the EC meter in $\mathrm{m}^{3} / \mathrm{s}$ was determined by solving for $f E C_{M S}$ in equation 1 using values of $E C_{B F}, E C_{A C}$, and $E C_{M S}$ that were $1 \mu \mathrm{S} / \mathrm{cm}$ greater than or less than the measured 
values. Minimum values for $f E C_{M S}$ were calculated when an $E C_{B F}$ value $1 \mu \mathrm{S} / \mathrm{cm}$ less than the measured value, and $E C_{M S}$ and $E C_{A C}$ values $1 \mu \mathrm{S} / \mathrm{cm}$ greater than their measured values were substituted into equation 1 . Maximum values for $f E C_{M S}$ were calculated when $E C_{B F}$ was $1 \mu \mathrm{S} / \mathrm{cm}$ greater than its measured value, and $E C_{M S}$, and $E C_{A C}$, were $1 \mu \mathrm{S} / \mathrm{cm}$ less than their measured values. Minimum and maximum values of $f E C_{M S}$ were substituted into equation 2 to solve for $Q_{M S}$. Minimum and maximum values of $Q_{M S}$ were 0.151 and $0.177 \mathrm{~m}^{3} / \mathrm{s}$ on $06 / 25 / 2007$, and 0.154 and $0.187 \mathrm{~m}^{3} / \mathrm{s}$ on 09/21/2007. The percent error attributed to the accuracy of the EC meter was $9 \%$ on $06 / 25 / 2007$ and $10 \%$ on $09 / 21 / 2007$. The total uncertainty associated with estimating $Q_{M S}$ via the EC mixing model was calculated using equation 3, where $E_{T E C}$ is the total error, in $\mathrm{m}^{3} / \mathrm{s}, e_{q b f}$ is the calculated discharge error at the measurement site below Frank Springs, in $\mathrm{m}^{3} / \mathrm{s}$, and $e_{e c}$ is the error in discharge attributed to the accuracy of the EC meter, in $\mathrm{m}^{3} / \mathrm{s}$ (Table 15$)$.

$$
E_{T E C}=\sqrt{e_{q b f}^{2}+e_{e c}^{2}}
$$

Table 15. Estimates of Discharge from the McKinney Butte Springs. $\mathrm{EC}_{\mathrm{AC}}$ and $\mathrm{EC}_{\mathrm{BF}}$ are electrical conductivities measured in Whychus Creek above Chester Springs and below Frank Springs. $\mathrm{EC}_{\mathrm{MS}}$ is the electrical conductivity measured in Frank Springs and represents electrical conductivity in the McKinney Butte Springs complex. $\mathrm{fEC}_{M S}$ is the fraction of EC in Whychus Creek provided by the McKinney Butte Springs as calculated in equation 1; and $Q_{W C B F}$ is the discharge in Whychus Creek below Frank Springs measured during seepage runs. $Q_{M S}$ is the estimated discharge from the McKinney Butte Springs calculated from electrical conductivity data using equation 2.

\begin{tabular}{|c|c|c|c|c|c|c|c|c|c|}
\hline Date & $\begin{array}{c}\mathrm{EC}_{\mathrm{AC}} \\
(\mu \mathrm{S} / \mathrm{cm}) \\
\text { measured }\end{array}$ & $\begin{array}{c}\text { EC }_{B F} \\
(\mu \mathrm{S} / \mathrm{cm}) \\
\text { measured }\end{array}$ & $\begin{array}{c}\mathrm{EC}_{\mathrm{MS}} \\
(\mu \mathrm{S} / \mathrm{cm}) \\
\text { measured }\end{array}$ & $\mathrm{fEC}_{\mathrm{MS}}$ & $\begin{array}{c}\mathbf{Q}_{\mathrm{WCBF}} \\
\left(\mathrm{m}^{3} / \mathrm{s}\right) \\
\text { measured }\end{array}$ & $\begin{array}{c}\mathbf{Q}_{\mathrm{MS}} \\
\left(\mathrm{m}^{3} / \mathrm{s}\right) \\
\text { calculated }\end{array}$ & $\begin{array}{c}\mathbf{e}_{\mathrm{qbf}} \\
\left(\mathrm{m}^{3} / \mathrm{s}\right)\end{array}$ & $\begin{array}{c}e_{e c} \\
\left(\mathrm{~m}^{3} / \mathrm{s}\right)\end{array}$ & $\begin{array}{c}E_{\text {TEC }} \\
\left(\mathrm{m}^{3} / \mathrm{s}\right)\end{array}$ \\
\hline $06 / 25 / 2007$ & 16 & 38 & 61 & 0.489 & 0.34 & 0.166 & 0.04 & 0.015 & 0.043 \\
\hline $09 / 21 / 2007$ & 19 & 33 & 63 & 0.318 & 0.54 & 0.171 & 0.05 & 0.017 & 0.053 \\
\hline
\end{tabular}


The temperature mixing model utilized temperature probe measurements collected every 10 minutes from $08 / 30 / 2007$ to $10 / 15 / 2007$ as another means of constraining estimates of discharge from the McKinney Butte Springs. Unlike the EC model which used instantaneous measurements of discharge and EC to estimate discharge from the McKinney Butte Springs, the temperature model used mean daily discharge in Whychus Creek recorded at the OWRD Gage Station in Sisters ( $\left.Q_{\text {SISTERS }}\right)$, mean daily temperatures from Whychus Creek above Chester Springs $\left(T_{A C}\right)$ and Whychus Creek below Frank Springs $\left(T_{B F}\right)$, and the mean temperature during the continuous data collection period in the McKinney Butte Springs $\left(T_{M S}\right)$ to estimate the average discharge from the McKinney Butte Springs during the continuous data collection period $\left(Q_{M S}\right)$. A major assumption in this model is that no significant gains or losses in streamflow occur between the gage in Sisters and the McKinney Butte Springs. As described in the Results section of the Chapter 4, while streamflow losses were measured between Sisters and the springs during each seepage run, the measured losses were within the margin of measurement error and may not represent actual losses.

The temperature model also differs from the EC model in that the equations used in the temperature model were not solved for $Q_{M S}$. Instead, specified values of $Q_{M S}$ ranging from 0.10 to $0.20 \mathrm{~m}^{3} / \mathrm{s}$ (i.e. $0.10,0.15,0.17,0.18,0.185,0.187,0.19$, and $0.20 \mathrm{~m}^{3} / \mathrm{s}$ ) were used to solve equations 4 and 5 for the fractions of total streamflow in Whychus Creek below the McKinney Butte Springs $\left(Q_{\text {TOTAL }}\right)$ supplied by discharge from Whychus Creek above the McKinney Butte Springs ( $\left.f Q_{S I S T E R S}\right)$ and by discharge 
from the McKinney Butte Springs $\left(f Q_{M S}\right)$, where $Q_{\text {TOTAL }}$ is the sum of $Q_{\text {SISTERS }}$ and $Q_{M S .} f Q_{\text {SISTERS }}$ and $f Q_{M S}$ were then used to solve equation 6 for $T_{B F}$. The predicted values of $T_{B F}$ calculated in equation 6 were compared to the observed values of $T_{B F}$ measured by the temperature probe. Mean daily temperatures for $T_{A C}$ and $T_{B F}$ calculated from temperature probe readings were used in equation 6 because discharge readings at the OWRD Gage Station in Sisters were only available in that form. The average temperature of Frank Springs $\left(9.04^{\circ} \mathrm{C}\right)$ during the continuous data collection period was used for $T_{M S}$ in equation 6 because its standard deviation $\left(\sigma=0.04{ }^{\circ} \mathrm{C}\right)$ was less than the accuracy of the temperature probes $\left( \pm 0.2^{\circ} \mathrm{C}\right)$.

$$
\begin{aligned}
& f Q_{\text {SISTERS }}=\frac{Q_{\text {SISTERS }}}{Q_{\text {TOTAL }}} \\
& f Q_{M S}=\frac{Q_{M S}}{Q_{\text {TOTAL }}} \\
& T_{B F}=\left(T_{A C} * f Q_{\text {SISTERS }}\right)+\left(T_{M S} * f Q_{M S}\right)
\end{aligned}
$$

Predicted values of $T_{B F}$ for given estimates of $Q_{M S}$ are compared graphically with measured $T_{B F}$ values in Figure 38. An estimated discharge of $0.10 \mathrm{~m}^{3} / \mathrm{s}$ from the springs under- or over-estimates $T_{B F}$; this is dependent on $T_{A C}$. A discharge of 0.20 $\mathrm{m}^{3} / \mathrm{s}$ fits the observed data better, but so do several other values (only $0.185 \mathrm{~m}^{3} / \mathrm{s}$ is shown, but $0.17,0.18$, and $0.187 \mathrm{~m}^{3} / \mathrm{s}$ all plot similarly). To quantify the goodness of fit between the predicted and observed values of $T_{B F}$, the sum of the squares of the differences between the observed and predicted values of $T_{B F}$ were calculated using equation 7. 


$$
S S=\sum_{i=1}^{n}\left(T_{B F o b s(i)}-T_{B F p r e d c t(i)}\right)^{2}
$$

Where, $S S$ is the sum of squares, $n$ is the number of sample observations, $T_{B F o b s(i)}$ is the observed mean daily temperature at Whychus Creek below Frank Springs, and $T_{B F p r e d i c t(i)}$ is the predicted mean daily temperature at Whychus Creek below Frank Springs. The $S S$ values determined from equation 7 are presented in Table 16. A constant spring discharge of $0.185 \mathrm{~m}^{3} / \mathrm{s}$ produces predicted temperatures with the lowest $S S$ value (0.614) which indicates it is the best fit to the observed data, and is likely a reasonable estimate of discharge from 08/30/2007 to 10/15/2007.

Uncertainty in estimates of discharge from the McKinney Butte Springs through the use of the temperature mixing model probably stem from 1) error in discharge measurements recorded at OWRD Gage Station in Sisters, and 2) the assumption that gains and losses between the gage in Sisters and the McKinney Butte Springs are minimal. Discharge measurements from the OWRD Gage Station in Sisters that were used in this study were considered "final" and were published by OWRD. The error associated with final data is generally no greater than $10 \%$ of the recorded discharge. The uncertainty associated with the assumption that no gains or losses in streamflow occur between Sisters and the McKinney Butte Springs is not as easily quantified. Losses of approximately $0.05 \mathrm{~m}^{3} / \mathrm{s}$ in streamflow between Sisters and the McKinney Butte Springs were measured during seepage runs on 06/25/2007, $09 / 21 / 2007$, and $01 / 30 / 2008$, and had associated errors of $0.05,0.06$, and $0.13 \mathrm{~m}^{3} / \mathrm{s}$, respectively. Although the uncertainties are as large as or larger than the measured losses, an assumed loss of $0.05 \mathrm{~m}^{3} / \mathrm{s}$ was used to account for the potential loss in 
streamflow. The median streamflow recorded at the Sisters Gage during the continuous data collection period (08/30/2007 to $10 / 15 / 2007)$ was $0.39 \mathrm{~m}^{3} / \mathrm{s}$. The assumed loss was divided by the median streamflow to approximate the uncertainty. The approximate uncertainty due to loss of streamflow between Sisters and the McKinney Butte Springs during the continuous data collection period was $13 \%$. The total error associated with estimation of $Q_{M S}$ through the use of the temperature mixing model was calculated using equation 8 where $E_{T T}$ is the total error, in percent, $e_{\text {sisters }}$ is the error in discharge measurements recorded at the OWRD Gage Station in Sisters, in percent, and $e_{\text {loss }}$ is the uncertainty due to potential loss in streamflow between Sisters and the McKinney Butte Springs, in percent.

$$
E_{T T}=\sqrt{e_{\text {sisters }}^{2}+e_{\text {loss }}^{2}}
$$

Table 16. Sum of Squares (SS) of differences between observed and predicted temperature values at Whychus Creek below Frank Springs for selected estimates of discharge from the McKinney Butte Springs $\left(Q_{M S}\right)$. A discharge of $0.185 \mathrm{~m}^{3} / \mathrm{s}$ is the best fit to the data, and represents the estimated discharge from the McKinney Butte Springs for the period between 08/30/2007 and 10/15/2007.

\begin{tabular}{cc}
\hline $\begin{array}{c}\mathbf{Q}_{\mathbf{M S}} \\
\left(\mathbf{m}^{\mathbf{3}} / \mathbf{s}\right)\end{array}$ & $\mathbf{S S}$ \\
\hline 0.100 & 7.058 \\
0.150 & 1.503 \\
0.170 & 0.762 \\
0.180 & 0.628 \\
0.185 & 0.614 \\
0.187 & 0.618 \\
0.190 & 0.633 \\
0.200 & 0.761 \\
\hline
\end{tabular}




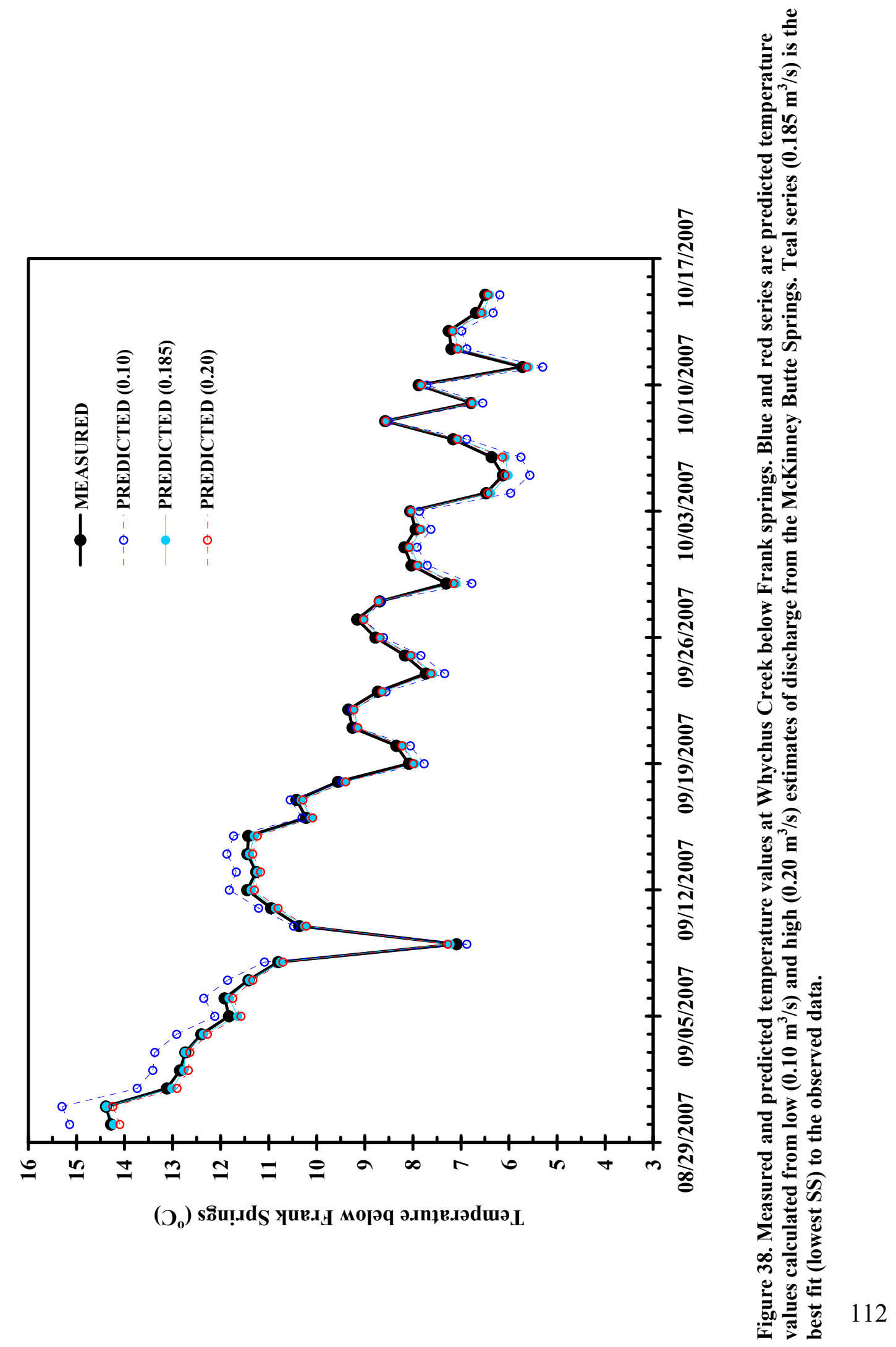


Discharge from the McKinney Butte Springs was estimated using the following three methods: 1) measurements of discharge in Whychus Creek above and below the springs (seepage runs), 2) electrical conductivity measurements in the springs and at sites on Whychus Creek above and below the springs, and 3) continuous temperature monitoring of the springs and locations in Whychus Creek above and below the springs. Uncertainty associated with each method was quite large and ranged from $28 \%$ to $66 \%$ for seepage runs, $26 \%$ to $31 \%$ for electrical conductivity, and $16 \%$ for temperature. However, estimates of discharge using all three methods on 09/21/2007 fell in a narrow range from $0.171 \mathrm{~m}^{3} / \mathrm{s}$ (electrical conductivity), to 0.192 $\mathrm{m}^{3} / \mathrm{s}$ (seepage runs) (Table 17, Figure 39). The agreement of discharge values calculated through the use of independent techniques suggests that although the uncertainty associated with each method is relatively large, when examined collectively, these methods provide a focused range of potential discharge from the McKinney Butte Springs. Based on discharge estimates presented in Table 17 and Figure 39 , low $\left(0.10 \mathrm{~m}^{3} / \mathrm{s}\right)$, mean $\left(0.20 \mathrm{~m}^{3} / \mathrm{s}\right)$, and high $\left(0.30 \mathrm{~m}^{3} / \mathrm{s}\right)$ estimates of discharge from the McKinney Butte Springs are used in the following section to examine the seasonal variability in their contribution to flow in Whychus Creek. 
Table 17. Estimates of discharge from the McKinney Butte Springs ( $\left.\mathbf{Q}_{M S}\right)$. Discharge was estimated via seepage runs on Whychus Creek and through the use of electrical conductivity and temperature data collected in the McKinney Butte Springs and at locations in Whychus Creek. Measured or calculated discharge estimates are presented along with minimum and maximum discharge values calculated from associated uncertainties.

\begin{tabular}{|c|c|c|c|c|c|c|c|c|c|}
\hline \multirow[b]{2}{*}{ Date } & \multicolumn{3}{|c|}{ Seepage Runs } & \multicolumn{3}{|c|}{ Electrical Conductivity } & \multicolumn{3}{|c|}{ Temperature } \\
\hline & $\begin{array}{c}\mathbf{Q}_{\mathrm{MS}} \\
\text { minimum } \\
\left(\mathrm{m}^{3} / \mathrm{s}\right)\end{array}$ & $\begin{array}{c}Q_{M S} \\
\text { measured } \\
\left(\mathrm{m}^{3} / \mathrm{s}\right)\end{array}$ & $\begin{array}{c}\mathrm{Q}_{\mathrm{MS}} \\
\text { maximum } \\
\left(\mathrm{m}^{3} / \mathrm{s}\right)\end{array}$ & $\begin{array}{c}\mathbf{Q}_{\mathrm{MS}} \\
\text { minimum } \\
\left(\mathrm{m}^{3} / \mathbf{s}\right)\end{array}$ & $\begin{array}{c}\mathrm{Q}_{\mathrm{MS}} \\
\text { measured } \\
\left(\mathrm{m}^{3} / \mathbf{s}\right)\end{array}$ & $\begin{array}{c}Q_{M S} \\
\text { maximum } \\
\left(\mathrm{m}^{3} / \mathrm{s}\right)\end{array}$ & $\begin{array}{c}\mathbf{Q}_{\mathrm{MS}} \\
\text { minimum } \\
\left(\mathrm{m}^{3} / \mathbf{s}\right)\end{array}$ & $\begin{array}{c}\mathrm{Q}_{\mathrm{MS}} \\
\text { measured } \\
\left(\mathrm{m}^{3} / \mathrm{s}\right)\end{array}$ & $\begin{array}{c}\mathrm{Q}_{\mathrm{MS}} \\
\underset{\left(\mathrm{m}^{3} / \mathrm{s}\right)}{\text { maximum }}\end{array}$ \\
\hline $04 / 16 / 2007$ & 0.134 & 0.187 & 0.240 & & & & & & \\
\hline $06 / 25 / 2007$ & 0.089 & 0.141 & 0.193 & 0.123 & 0.166 & 0.209 & & & \\
\hline $08 / 30 / 2007$ & & & & & & & 0.155 & 0.185 & 0.215 \\
\hline $09 / 21 / 2007$ & 0.127 & 0.192 & 0.257 & 0.118 & 0.171 & 0.224 & 0.155 & 0.185 & 0.215 \\
\hline $10 / 15 / 2007$ & & & & & & & 0.155 & 0.185 & 0.215 \\
\hline $01 / 30 / 2008$ & 0.069 & 0.201 & 0.333 & & & & & & \\
\hline
\end{tabular}




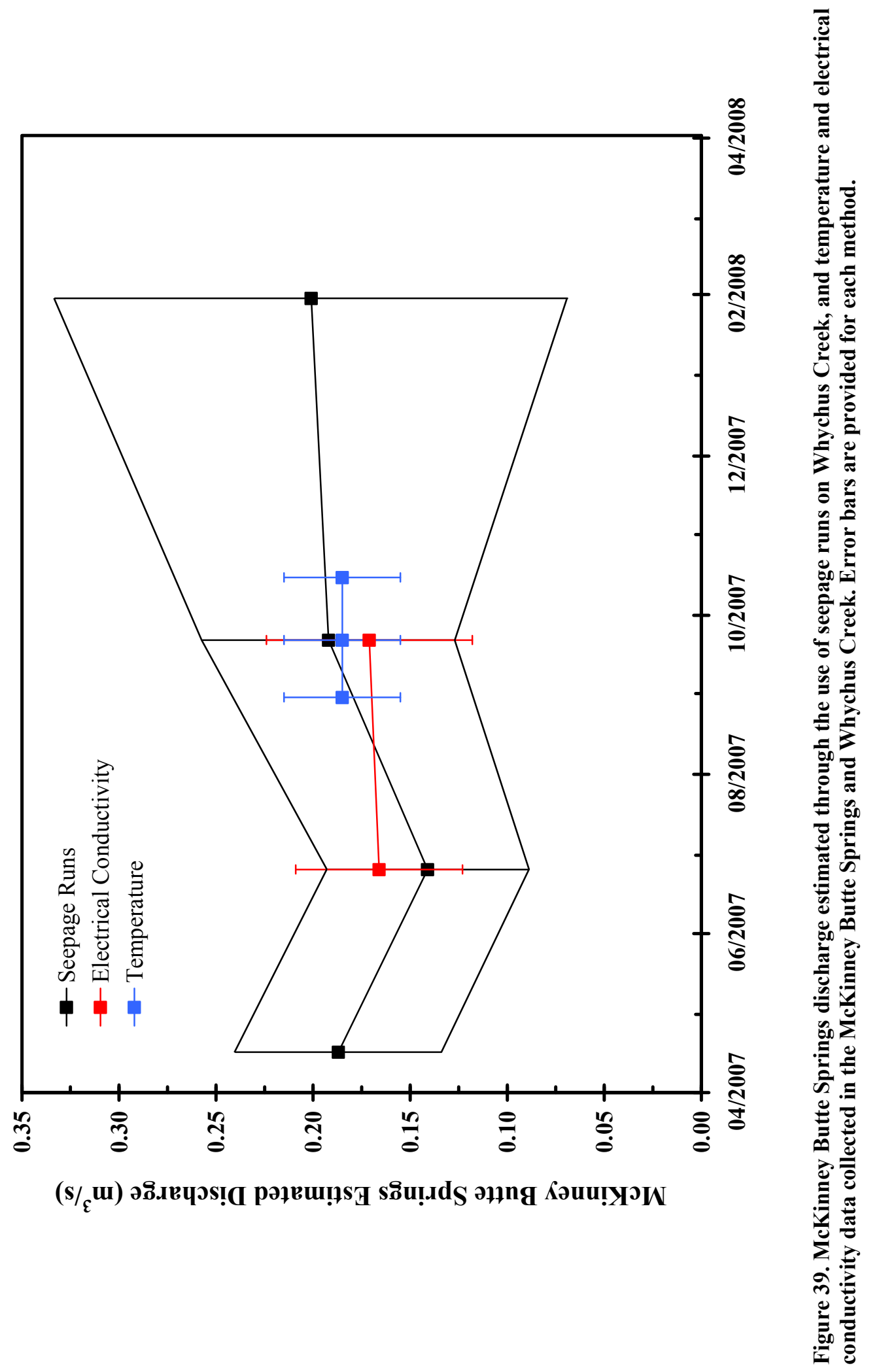




\section{Discharge Contribution to Whychus Creek}

The flow regime of Whychus Creek is typical of a runoff-dominated stream (Whiting and Stamm, 1995). Historically, Whychus Creek has exhibited large seasonal variations in discharge with peak flows generally occurring in late spring and early summer in response to spring snowmelt, and low flows occurring in late summer and early fall due to low precipitation (Figure 40). However, recent data suggests, at least during years of below normal early summer precipitation (i.e. 2007), peak discharge may occur during late fall or early winter (Figure 41). As a result, the percentage of total discharge in Whychus Creek provided by the McKinney Butte Springs can vary widely on both seasonal and yearly time scales. Discharge values of $0.10 \mathrm{~m}^{3} / \mathrm{s}$ (low estimate), $0.20 \mathrm{~m}^{3} / \mathrm{s}$ (mean estimate), and $0.30 \mathrm{~m}^{3} / \mathrm{s}$ (high estimate) were used to estimate the percent of streamflow in Whychus Creek supplied by the McKinney Butte Springs on daily and monthly bases from 01/2006 to 02/2008 (Figure 42). Estimated monthly discharge contributions from the McKinney Butte Springs to Whychus Creek range from as little as 3-7\% during winter (January - February 2006, November 2006 - March 2007 and November 2007 - February 2008) and early summer (June - July 2006) months; to as much as $24-46 \%$ during late summer months. Estimated daily contributions range from $1 \%$ to $59 \%$ of total stream discharge. The estimates of contributed discharge presented in Figure 42 indicate that the McKinney Butte Springs will have the most impact on Whychus Creek during times of low flow in the creek. 


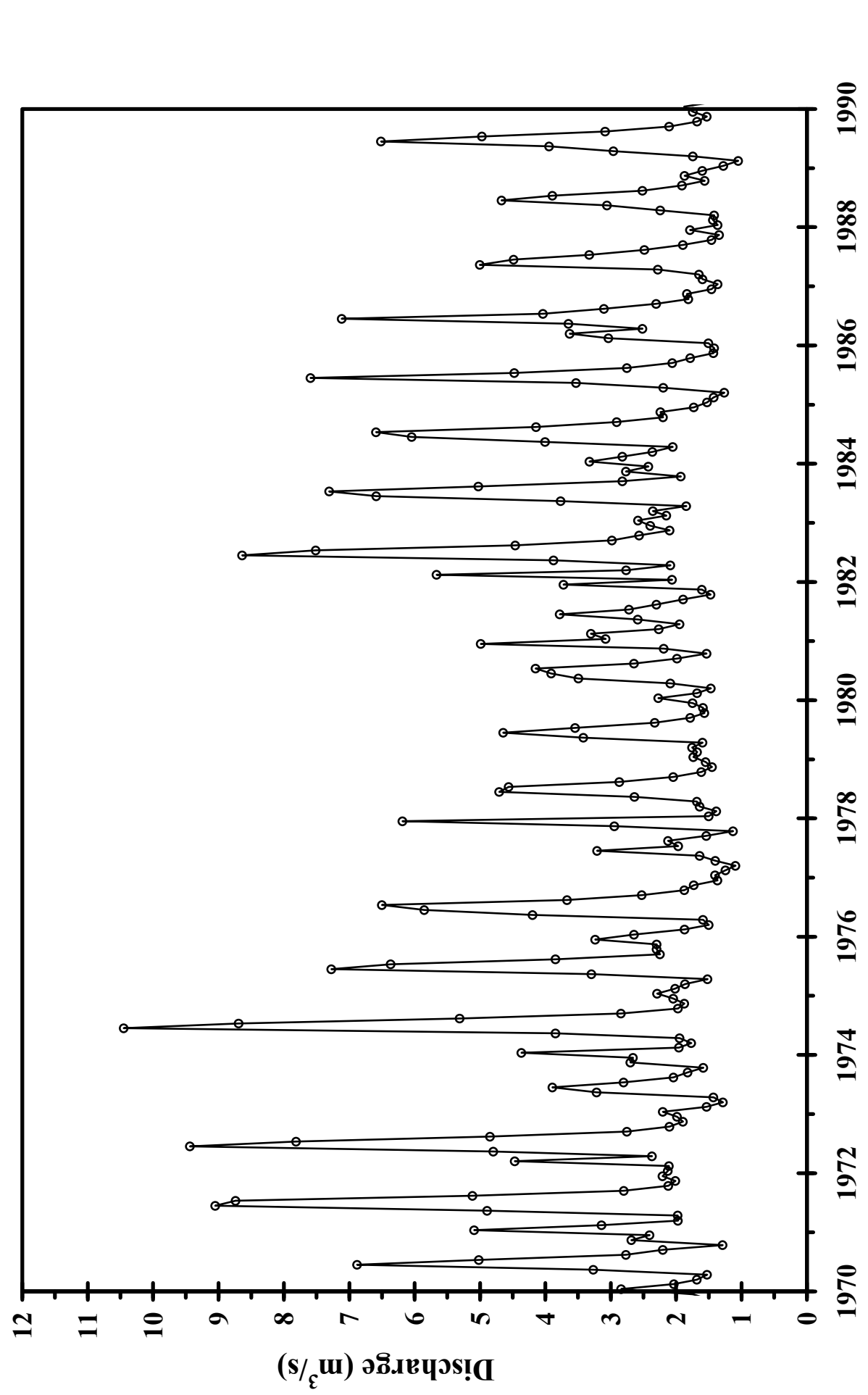




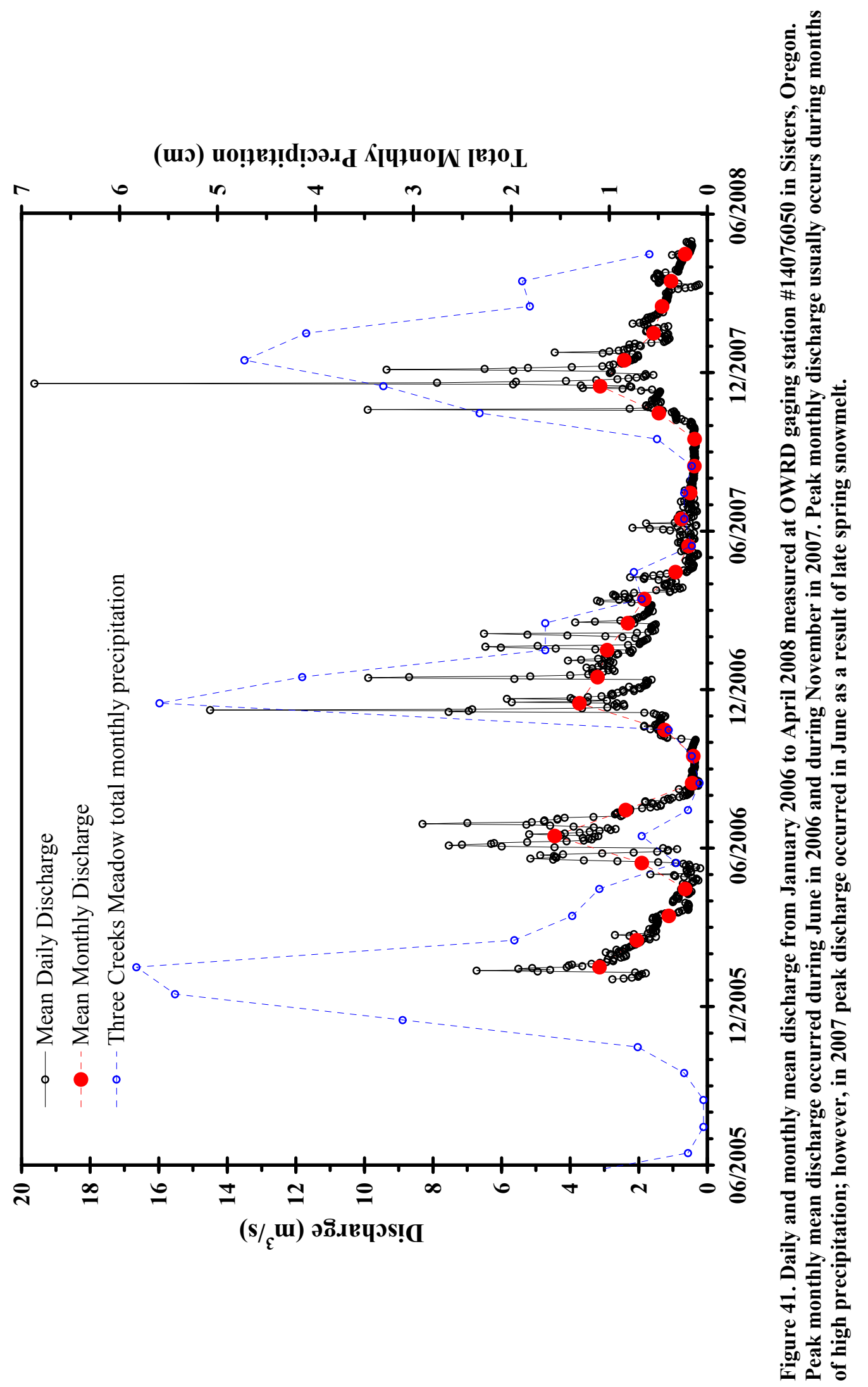




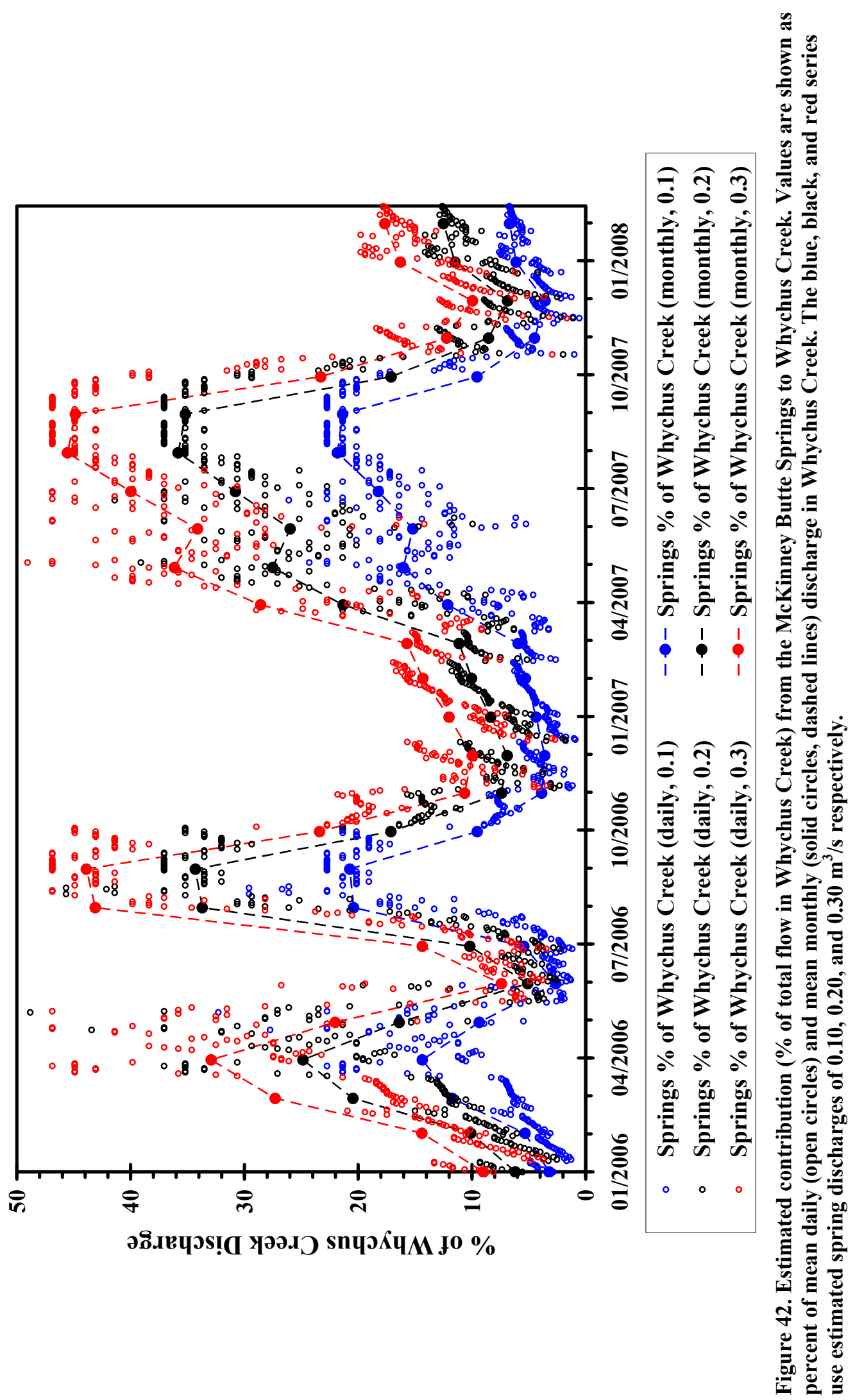

119 


\section{Thermal Contribution to Whychus Creek}

Temperature measurements collected every 10 minutes from 08/30/2007 to $10 / 15 / 2007$ were analyzed to assess the thermal contribution of the McKinney Butte springs to Whychus Creek. Locally, the springs act as a buffer against temperature variations in Whychus Creek (Figure 43). Figure 43 is similar to Figure 36, however it does not show Sisters air temperature. This was done to reduce the temperature scale, making the temperature difference above Chester Springs and below Frank Springs easier to see. Above Chester springs, the difference between low and high temperatures is greater than below Frank springs. The magnitude of the springs' impact on Whychus Creek is a function of the temperature and discharge in the creek above the springs. Similar to the discharge contribution discussed in the previous section, the McKinney Butte Springs will have a greater thermal impact during times of low flow in Whychus Creek. The thermal contribution from the springs will be greatest 1) when the temperature difference between the springs and Whychus Creek is large, and 2) during low-flow conditions. As indicated in Figure 40, the timing of low-flow conditions in Whychus Creek may vary from year to year, however, discharge is generally lowest in mid to late summer. 

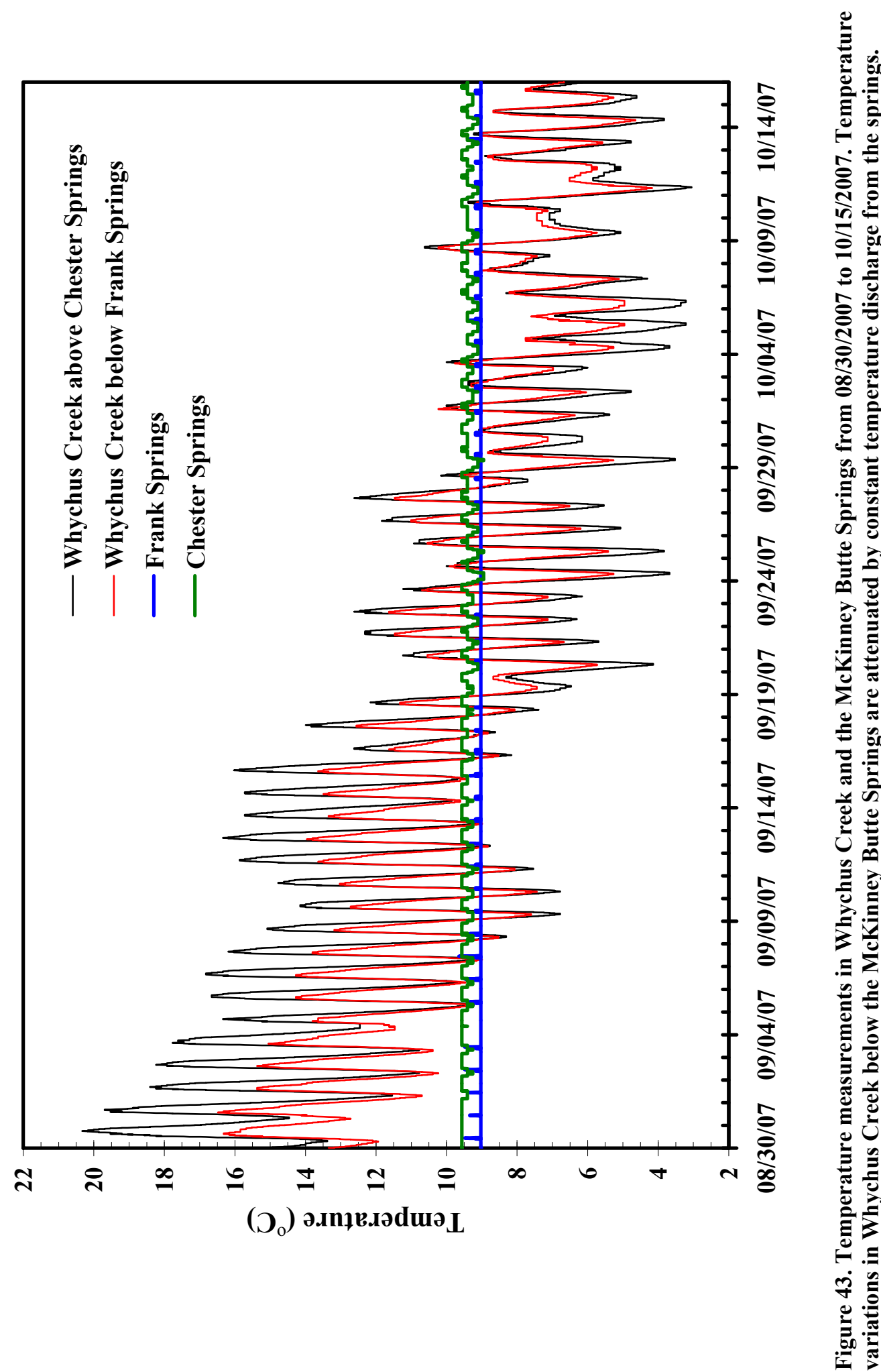


\section{Source of McKinney Butte and Camp Polk Springs}

Springs are windows into subsurface flow systems. Determination of a spring's source can provide information about local geology and the spatial scale of groundwater flow. Because springs discharge water that may be recharged at several locations along the length of an aquifer, "source" refers to an area where most of the recharge originates and the subsequent path(s) groundwater takes on its way to a spring. Tóth (1963) identified three different "scales" of ground-water flowpaths: local, intermediate, and regional. Local groundwater flow systems typically circulate to shallow depths and discharge proximal to recharge areas, while intermediate and regional groundwater circulate to greater depths and discharge far from inferred recharge areas. Generally, groundwater that circulates to greater depths in an aquifer is less susceptible to contamination and short-term variations in recharge than groundwater that circulates to shallow depths. Thus, understanding the spatial scales of groundwater flow in an area is valuable when addressing water quality and water resource management issues.

Establishing the source of a spring involves measurement and interpretation of its physical, chemical, thermal, and isotopic characteristics. Seasonal variations in discharge and temperature are related to the scale of groundwater flow; deeper (and consequently longer) flowpaths attenuate fluctuations. Chemical characteristics (i.e. dissolved ions, alkalinity, conductivity, $\mathrm{pH}$ ) will vary depending on the amount of time a mass of groundwater has spent in an aquifer (residence time) and the geologic 
materials it contacts. The stable isotopes of oxygen and hydrogen fractionate predictably as they pass through the hydrologic system, as a result, isotopic signatures are a function of recharge elevation. Comparing the hydrogeologic characteristics of a spring with nearby springs and surface water sources provides another avenue for determining the source area of a spring. Analysis of physical and chemical hydrogeologic data provides a framework for distinguishing source regions and flowpaths of groundwater discharged at springs.

In this section, light stable isotope data and water chemistry and water quality parameters of the McKinney Butte Springs, Camp Polk Springs, Paulina Spring, Alder Springs, Metolius Spring and Whychus and Indian Ford creeks are examined with the goal of determining the source and scale of groundwater flow discharging at the McKinney Butte and Camp Polk Springs.

\section{Major Ions}

The amount of time water is in the ground, known as residence time, increases as the water flows from recharge areas in a groundwater system to areas of discharge. The greater the residence time, the longer the water has to react with aquifer material and dissolve minerals. Therefore, the concentration of dissolved ions in groundwater generally increases along regional flowpaths. In a study of the geochemistry of surface water and groundwater in the upper Deschutes Basin, Caldwell (1998) showed that concentrations of dissolved ions were lowest in the regional recharge area in and around the Cascade Range, and dissolved ion concentrations generally increased to the 
east in the regional discharge area near the confluence of the Deschutes and Crooked rivers.

Concentrations of major ionic species in study area springs and streams were used in the examination of source area and potential groundwater flowpaths for the springs on McKinney Butte (springs on McKinney Butte include: The McKinney Butte Springs (Chester Springs and Frank Springs) and The Camp Polk Springs (Camp Polk Springhouse and Anderson Springs)). Source areas for several of the springs sampled during the current study have been determined in previous investigations (Metolius Spring, Paulina Spring, and Alder Springs). In her examination of the use of isotope tracers in the Oregon Cascades, James (1999) concluded that groundwater discharging from Metolius Spring was recharged at high elevations near the crest of the Cascades and followed deep regional flowpaths. Caldwell (1998) showed that discharge from Alder Springs is comprised mainly of regional-scale groundwater flow, but contains a component of locally recharged groundwater; Paulina Spring, the source of Indian Ford Creek, discharges locally derived groundwater; and Lower Opal Springs, a high volume spring located in the regional discharge area, discharges groundwater that has followed regional-scale flowpaths from the Cascades. Major ion data from these springs serve primarily as a comparison for streams and springs sampled during this study.

In general, the major ion geochemistry of streams and springs sampled during this study are similar. $\mathrm{HCO}_{3}$ is the dominant anionic species in all 52 samples, and no cationic species is dominant in 34 samples, while 13 samples from Whychus Creek, 
two samples from The McKinney Butte Springs and the sample from Metolius Spring are slightly Na dominant, and two samples from Camp Polk Springhouse are slightly Mg dominant. Total ionic concentrations are generally higher in samples from springs, with the exception of Paulina Spring whose total ionic concentration was similar to Whychus Creek below the McKinney Butte Springs and lower than Indian Ford Creek. Differences do exist, however, and are most prominent in $\mathrm{NO}_{3}, \mathrm{Cl}$, and $\mathrm{SO}_{4}$. Concentrations of $\mathrm{Cl}$ and $\mathrm{NO}_{3}$ in Camp Polk Springhouse (4.32 to $5.59 \mathrm{mg} / \mathrm{L}$ and 2.59 to $4.52 \mathrm{mg} / \mathrm{L}$, respectively) are more than two times greater than concentrations at most other sites and $\mathrm{SO}_{4}$ concentrations $(1.74$ to $3.01 \mathrm{mg} / \mathrm{L})$ are approximately 1.5 times greater than at other sites. The sample from Metolius Spring is an exception, with an $\mathrm{NO}_{3}$ concentration of $7.59 \mathrm{mg} / \mathrm{L}$. Whychus and Indian Ford creeks generally have the lowest $\mathrm{NO}_{3}, \mathrm{Cl}$, and $\mathrm{SO}_{4}$; however some variability exists in $\mathrm{Cl}$ concentrations in Indian Ford Creek, which range from 0.46 to $2.26 \mathrm{mg} / \mathrm{L}$.

High concentrations of $\mathrm{NO}_{3}, \mathrm{Cl}$ and $\mathrm{SO}_{4}$ in Camp Polk Springhouse are of particular interest because concentrations of these ions in Anderson Springs and the McKinney Butte Springs, located 0.2 and 2.0 to $2.5 \mathrm{~km}$ upstream from Camp Polk Springhouse, are significantly lower. Additionally, $\mathrm{NO}_{3}, \mathrm{Cl}$, and $\mathrm{SO}_{4}$ concentrations in springs that discharge regional-scale groundwater (Lower Opal, and Alder Springs) are also significantly lower than concentrations in Camp Polk Springhouse. Also of interest is the elevated $\mathrm{NO}_{3}$ concentration in Metolius Spring.

There is commonly a relationship between the chemical characteristics of groundwater and the mineralogical properties of the geologic material with which it 
has been in contact. The geological units of the upper Deschutes Basin consist mainly of lavas, tuffaceous material, and volcaniclastic sediments of Cascade Range origin. These rocks of igneous origin are composed of silicate minerals such as olivine, pyroxene, amphibole, mica and feldspar. Dissolution of silicate minerals is the major process that controls groundwater chemistry in igneous terrain and typically results in the formation of clay and the release to aqueous solution of dissolved silica in the form of silicic acid $\left(\mathrm{H}_{4} \mathrm{SiO}_{4}\right)$ and metal cations such as $\mathrm{Ca}, \mathrm{Na}, \mathrm{Mg}$, and $\mathrm{K}$. The weathering of albite, a Na feldspar, to kaolinite, a clay, is representative of these reactions:

$$
2 \mathrm{NaAlSi}_{3} \mathrm{O}_{8}+2 \mathrm{H}^{+}+9 \mathrm{H}_{2} \mathrm{O} \rightarrow \mathrm{Al}_{2} \mathrm{Si}_{2} \mathrm{O}_{5}(\mathrm{OH})_{4}+2 \mathrm{Na}^{2+}+4 \mathrm{H}_{4} \mathrm{SiO}_{4}
$$

Minerals in which $\mathrm{NO}_{3}, \mathrm{Cl}$, and $\mathrm{SO}_{4}$ are essential components are not very common in igneous rocks (Hem, 1985), suggesting a process other than water-rock interaction controls the amount of these anions in Camp Polk Springhouse and the amount of $\mathrm{NO}_{3}$ Metolius Spring.

Elevated concentrations of $\mathrm{NO}_{3}, \mathrm{Cl}$, and $\mathrm{SO}_{4}$ are regularly found in anthropogenic sources such as septic effluent, fertilizers, and animal wastes (Canter and Knox, 1985). In the vicinity of McKinney Butte, potential anthropogenic sources are limited to septic effluent and fertilizers; confined feed lots or high density grazing (major sources of animal waste) are not locally present in areas up-gradient from the springs. Irrigation occurs in the area around McKinney Butte; however, only an average of $8.8 \%$ of the acreage in sections on, and bordering the west side of, McKinney Butte are covered by irrigation water rights (OWRD, 2011b) (Table 18). The low occurrence of irrigation locally suggests septic-tank effluent is the most likely 
source of elevated $\mathrm{NO}_{3}, \mathrm{Cl}$, and $\mathrm{SO}_{4}$ concentrations in Camp Polk Springhouse. Additional evidence supporting a septic effluent source is considerably lower $\mathrm{NO}_{3}, \mathrm{Cl}$, and $\mathrm{SO}_{4}$ concentrations in Anderson Springs and the McKinney Butte Springs. Fertilizers used for irrigation purposes are typically applied evenly over the land surface, and should therefore be more evenly distributed in the subsurface. Lower $\mathrm{NO}_{3}, \mathrm{Cl}$, and $\mathrm{SO}_{4}$ concentrations in Anderson Springs and the McKinney Butte Springs suggest the source responsible for the elevated concentrations in Camp Polk Springhouse is localized. As is shown later in this chapter, the McKinney Butte Springs discharge groundwater that has circulated deep in the aquifer system, which explains its low $\mathrm{NO}_{3}, \mathrm{Cl}$, and $\mathrm{SO}_{4}$ concentrations . Conversely, like Camp Polk Springhouse, Anderson Springs discharges groundwater that has followed shallow flow paths and should contain elevated concentrations of $\mathrm{NO}_{3}, \mathrm{Cl}$, and $\mathrm{SO}_{4}$ if fertilizer is the source. The most reasonable explanation for the variation in $\mathrm{NO}_{3}, \mathrm{Cl}$, and $\mathrm{SO}_{4}$ concentrations in proximally located springs is a point source origin such as a septictank effluent plume. The fact that many small acreage parcels, each with their own septic system, are found on McKinney Butte is also consistent with a septic-tank effluent origin.

Hinkle et al. (2007) found that elevated concentrations of $\mathrm{Cl}, \mathrm{NO}_{3}$, and $\mathrm{SO}_{4}$ in shallow wells in the LaPine basin (located in the southern portion of the upper Deschutes basin) were caused by contamination of the aquifer from septic-tank effluent and concluded that heterogeneous distributions of $\mathrm{NO}_{3}$ concentrations in the subsurface is consistent with a number of point sources of septic-tank derived $\mathrm{NO}_{3}$ 
rather than a uniform nonpoint source such as agricultural sources. These findings are also consistent with the argument presented above for a septic-tank effluent source of elevated $\mathrm{Cl}, \mathrm{NO}_{3}$, and $\mathrm{SO}_{4}$ concentrations in Camp Polk Springhouse.

Table 18. Total acreage covered by irrigation water rights in sections bordering the west side of McKinney Butte and sections on McKinney Butte. Data from Oregon Water Resources Department Water Rights Information System (WRIS) database.

\begin{tabular}{|c|c|c|c|c|c|}
\hline Township & Range & Section & $\begin{array}{c}\text { Acres on Irrigation } \\
\text { Water Rights }\end{array}$ & $\begin{array}{c}\text { Total Acres } \\
\text { in Section }\end{array}$ & $\begin{array}{c}\text { \% of Total Acres } \\
\text { on Irrigation } \\
\text { Water Rights }\end{array}$ \\
\hline \multicolumn{6}{|c|}{ West of McKinney Butte } \\
\hline $14 \mathrm{~S}$ & $10 \mathrm{E}$ & 16 & 7.30 & 640 & 1.1 \\
\hline $14 \mathrm{~S}$ & $10 \mathrm{E}$ & 21 & 110.70 & 640 & 17.3 \\
\hline $14 \mathrm{~S}$ & $10 \mathrm{E}$ & 33 & 110.94 & 640 & 17.3 \\
\hline $15 \mathrm{~S}$ & $10 \mathrm{E}$ & 3 & 28.55 & 640 & 4.5 \\
\hline $15 \mathrm{~S}$ & $10 \mathrm{E}$ & 4 & 119.81 & 640 & 18.7 \\
\hline \multicolumn{6}{|c|}{ On McKinney Butte } \\
\hline $14 \mathrm{~S}$ & $10 \mathrm{E}$ & 34 & 8.00 & 640 & 1.3 \\
\hline $15 \mathrm{~S}$ & $10 \mathrm{E}$ & 2 & 8.50 & 640 & 1.3 \\
\hline \multicolumn{6}{|c|}{ Total Acres } \\
\hline & & & 393.80 & 4480 & 8.8 \\
\hline
\end{tabular}

Determination of the source of elevated $\mathrm{NO}_{3}$ concentrations in Metolius Spring is not as straightforward. Land use patterns in the Metolius Spring area are broadly similar to those around McKinney Butte; irrigation is limited and small-acreage residential lots are abundant. Black Butte Ranch, a local resort community, is the site of the only up-gradient irrigation and residential development in the Metolius Spring area. However, unlike the McKinney Butte area, many homes in Black Butte Ranch are served by gravity sewers and fewer homes have septic-tanks (Black Butte Ranch, 2010). Two 18-hole golf courses at the ranch are maintained with 361.5 acres of irrigation water rights (the water right certificate is for 361.5 acres) (OWRD, 2011b). Septic effluent and irrigation water are both potential sources of $\mathrm{NO}_{3}$ in Metolius 
Spring. Additional complications stem from the fact that Black Butte Ranch is located over $7 \mathrm{~km}$ south of Metolius Spring, allowing ample time for mixing of multiple $\mathrm{NO}_{3}$ sources and, potentially, denitrification in the subsurface.

In contrast to Camp Polk Springhouse, concentrations of $\mathrm{Cl}$ and $\mathrm{SO}_{4}$ in Metolius Spring are not elevated and are comparable to concentrations found in the McKinney Butte Springs, Anderson Springs, Alder Springs, and Lower Opal Springs. This suggests that the source of $\mathrm{NO}_{3}$ in Metolius Spring does not contain elevated concentrations of $\mathrm{Cl}$ and $\mathrm{SO}_{4}$. Possible explanations include differences in the chemical constituents found in septic-tank effluent in the Metolius Spring area versus the McKinney Butte area, or fertilizer that contains significantly more $\mathrm{NO}_{3}$ than $\mathrm{Cl}$ or $\mathrm{SO}_{4}$. The latter interpretation is consistent with golf course irrigation; most grasses require large quantities of nitrogen (De Loach, 1921).

Chitwood (1999) sampled Metolius Spring for $\mathrm{NO}_{3}$ eight times between May 1996 and May 1997. $\mathrm{NO}_{3}$ concentrations ranged from 0.44 to $3.36 \mathrm{mg} / \mathrm{L}$ and 6 of the 8 samples contained $\mathrm{NO}_{3}$ concentrations below $1 \mathrm{mg} / \mathrm{L}$ (Table 15). The highest $\mathrm{NO}_{3}$ concentration was measured on 05/02/1997 and was approximately 4 times greater than the concentration measured less than two months earlier $(0.80 \mathrm{mg} / \mathrm{L}$ on 03/13/1997). The $\mathrm{NO}_{3}$ concentration measured on $05 / 02 / 1997$ is comparable to concentrations in Camp Polk Springhouse, but is approximately 50\% less than the $\mathrm{NO}_{3}$ concentration measured in Metolius Spring during the current study. Chitwood (1999) did not postulate a source for elevated $\mathrm{NO}_{3}$ concentrations in Metolius Spring, but he did conclude that $\mathrm{NO}_{3}$ and $\mathrm{PO}_{4}$ from septic systems in the Camp Sherman area, 
located $3 \mathrm{~km}$ downstream (north) from Metolius Spring are carried by groundwater to the Metolius River. Large variations in $\mathrm{NO}_{3}$ concentrations reported by Chitwood (1999) indicate that the source is not constant, but varies temporally. Although the source of $\mathrm{NO}_{3}$ is uncertain, elevated concentrations indicate that a portion of discharge from the spring is provided by shallow groundwater flow.

\section{Stable Isotopes}

Oxygen and hydrogen isotopes are commonly used to determine groundwater recharge areas and regional groundwater flow patterns. Their usefulness stems from the fact that they fractionate in a predictable manner as water moves through the hydrologic cycle depending on the physical and chemical processes that operate (Criss, 1999). Fractionation occurs because two isotopes of the same element have different masses, and hence possess slightly different physiochemical properties. As a result, isotopes are partitioned unequally during chemical reactions. The stable isotopes of light elements (e.g., hydrogen and oxygen) have large relative mass differences, so their fractionation effects are more pronounced and more easily detected than those of the heavy elements.

There are two stable isotopes of hydrogen: ${ }^{1} \mathrm{H}$ and ${ }^{2} \mathrm{H}$ (deuterium), and three of oxygen: ${ }^{16} \mathrm{O},{ }^{17} \mathrm{O}$, and ${ }^{18} \mathrm{O}$, of which ${ }^{16} \mathrm{O}$ and ${ }^{18} \mathrm{O}$ are more abundant. Because the vapor pressure of water molecules is inversely proportional to their masses, water vapor is depleted in the heavier isotopes ${ }^{2} \mathrm{H}$ and ${ }^{18} \mathrm{O}$ relative to coexisting liquid water (Faure, 1986). During phase changes in general, the heavy isotopes are preferentially 
partitioned into the more condensed phase. For example, for the various phases of water, at equilibrium, $\delta^{18} \mathrm{O}_{\text {solid }}>\delta^{18} \mathrm{O}_{\text {liquid }}>\delta^{18} \mathrm{O}_{\text {gas }}$ (Kendall and McDonnell, 1998). This fact indicates that the relative abundance of the heavy to light isotopes changes in a predictable manner as water moves through the hydrologic cycle and has important implications for determining the source of springs.

Craig (1961) established that there is a linear relationship between $\delta^{18} \mathrm{O}$ and $\delta^{2} \mathrm{H}$ in precipitation on a global scale. The relationship is known as the Global Meteoric Water Line and is described by:

$$
\delta^{2} H=8 \delta^{18} O+10
$$

The slope of this line, 8 , reflects the difference in fractionation behavior between ${ }^{18} \mathrm{O}$ and ${ }^{2} \mathrm{H}$ and is related to the amount of energy required to break chemical bonds, known as zero point energy (ZPE) between isotopes of the same element. Molecules containing heavy isotopes are more stable than molecules with lighter isotopes (Kendall and McDonnell, 1998). Because the relative mass difference between ${ }^{2} \mathrm{H}$ and ${ }^{1} \mathrm{H}$ is greater than the mass difference between ${ }^{18} \mathrm{O}$ and ${ }^{16} \mathrm{O}$, the magnitude of fractionation between isotopes of $\mathrm{H}$ is 8 times greater than between isotopes of $\mathrm{O}$.

The two major factors that control the isotopic concentration of precipitation at any location are temperature and the proportion of the original water vapor that remains in the air that is undergoing precipitation; these two factors can produce geographic and temporal variations in precipitation (Kendall and McDonnell, 1998). The result of these factors is that isotopic concentrations in precipitation will vary with 
distance from the source of the water vapor (continental and latitude effects), elevation, season, and amount (Kendall and McDonnell, 1998).

The continental effect is an observation that meteoric water is more depleted farther from source of the water vapor. As an air mass moves inland, the heavier isotopes are preferentially partitioned in the liquid phase leaving the residual vapor more depleted. Subsequent precipitation events are further depleted, although still enriched relative to the residual vapor (Clark and Fritz, 1997; Kendall and McDonnell, 1998).

Elevation and latitude effects are somewhat related to the continental effect in that progressive rainout of the parent vapor is responsible for some of the depletion of heavy isotopes at higher elevations and latitudes (Kendall and McDonnell, 1998). However, temperature also plays a significant role due to increased fractionation at lower temperatures found at higher elevations and latitudes.

Temperature is also the controlling factor for seasonal variations in the isotopic composition of precipitation (Kendall and McDonnell, 1998). Regions that experience large seasonal fluctuations in surface temperature exhibit large variations in the isotopic composition of precipitation (Ingraham et al., 1991; Jacob and Sonntag, 1991). In general winter precipitation is more depleted than summer precipitation due to low temperatures experience during winter months.

The isotopic composition of precipitation is also influenced by the amount that occurs. Water collected during smaller rainfall events can be isotopically enriched relative to water collected during larger events. This phenomenon is caused by 
evaporation at the surface of individual raindrops during descent and is related to the relative humidity in the atmosphere. During longer rainstorms the air below cloud base may become more saturated which reduces the amount of evaporative loss of the raindrops (Kendall and McDonnell, 1998). The amount effect is especially pronounced in arid environments and can result in a local meteoric water line with a slope that is less than the GMWL (Friedman et al., 1992). However, the amount effect is not as severe at higher latitudes where more precipitation is in the form of snow, which is not subjected to isotopic fractionation by evaporation during descent (Kendall and McDonnell, 1998).

Precipitation that occurs in central Oregon typically originates in air masses in the Pacific Ocean and forms by condensation within clouds. As a result, precipitation is enriched in ${ }^{2} \mathrm{H}$ and ${ }^{18} \mathrm{O}$ relative to residual vapor, although the values are not as high as those for seawater (Craig and Gordon, 1965). Air masses moving east from the coast of Oregon must ascend and release moisture as they move across the Cascades. As these air masses move east, subsequent precipitation events are further depleted in ${ }^{2} \mathrm{H}$ and ${ }^{18} \mathrm{O}$, although still enriched relative to the residual vapor (Clark and Fritz, 1997).

James (1999) argued that elevation is the most important factor affecting the isotopic composition of precipitation in the central Oregon Cascades. Her argument was based on the analysis of 76 snow core samples and 56 water samples from cold springs to the east of the Cascade crest. Seasonal effects were discounted because the majority of precipitation to the east of the crest falls as snow during the winter. 
Latitude effects were considered unimportant due to similarities in $\delta^{18} \mathrm{O}$ in precipitation samples from locations in the southern (Willamette Pass), central (Mt. Bachelor), and northern (Santiam Pass) parts of her study area (see Figure 4.7 in James, 1999). She did find a correlation between distance from the coast and $\delta^{18} \mathrm{O}$, but attributed it to the general decrease in elevation from west to east from the Cascade crest.

James (1999) found a linear relationship between elevation and $\delta^{18} \mathrm{O}$ in precipitation samples for the central Oregon Cascades that is given by the equation:

$$
\delta^{18} O=-0.0018(\text { elevation in } m)-10.9
$$

Equation 11 indicates there is a decrease of $0.18 \%$ per $100 \mathrm{~m}$ rise in elevation. Considerable scatter in hydrogen isotope data $\left(\mathrm{R}^{2}=0.0066\right)$ prevented determination of the relationship between $\delta^{2} H$ and elevation. Some scatter also exists in the relationship between elevation and $\delta^{18} \mathrm{O}$ (Figure 44), but it is consistent with the elevation relationship determined for other regions (Table 19).

Table 19. Gradients of $\delta^{18} \mathrm{O}$ with elevation (After Clark and Fritz, 1997).

\section{Gradient}

$$
\left(\delta^{18} \mathrm{O} \%\right.
$$

\begin{tabular}{llll}
\multicolumn{1}{c}{ Site } & \multicolumn{1}{c}{ Region } & \multicolumn{1}{c}{ per 100 m) } & \multicolumn{1}{c}{ Reference } \\
\hline Jura Mountains & Switzerland & -0.2 & Siegenthaler et al., 1980 \\
Black Forest & Switzerland & -0.19 & Dubois and Flück, 1984 \\
Mont Blanc & France & -0.5 & Moser and Stichler, 1970 \\
Coast Mountains & British Columbia -0.25 & Clark et al., 1982 \\
Piedmont & Western Italy & -0.31 & Bortolami et al., 1978 \\
Dhofar Monsoon & Southern Oman & -0.10 & Clark, 1987 \\
Saiq Plateau & Northern Oman & -0.12 & Stanger, 1986 \\
Mount Camaroon & West Africa & -0.155 & Fontes and Olivry, 1977 \\
Hat Creek Basin & Northern CA & -0.23 & Rose et al., 1996 \\
Urumqu River Basin Xinjiang, China & -0.4 & Weizu and Longinelli, 1993 \\
\hline
\end{tabular}




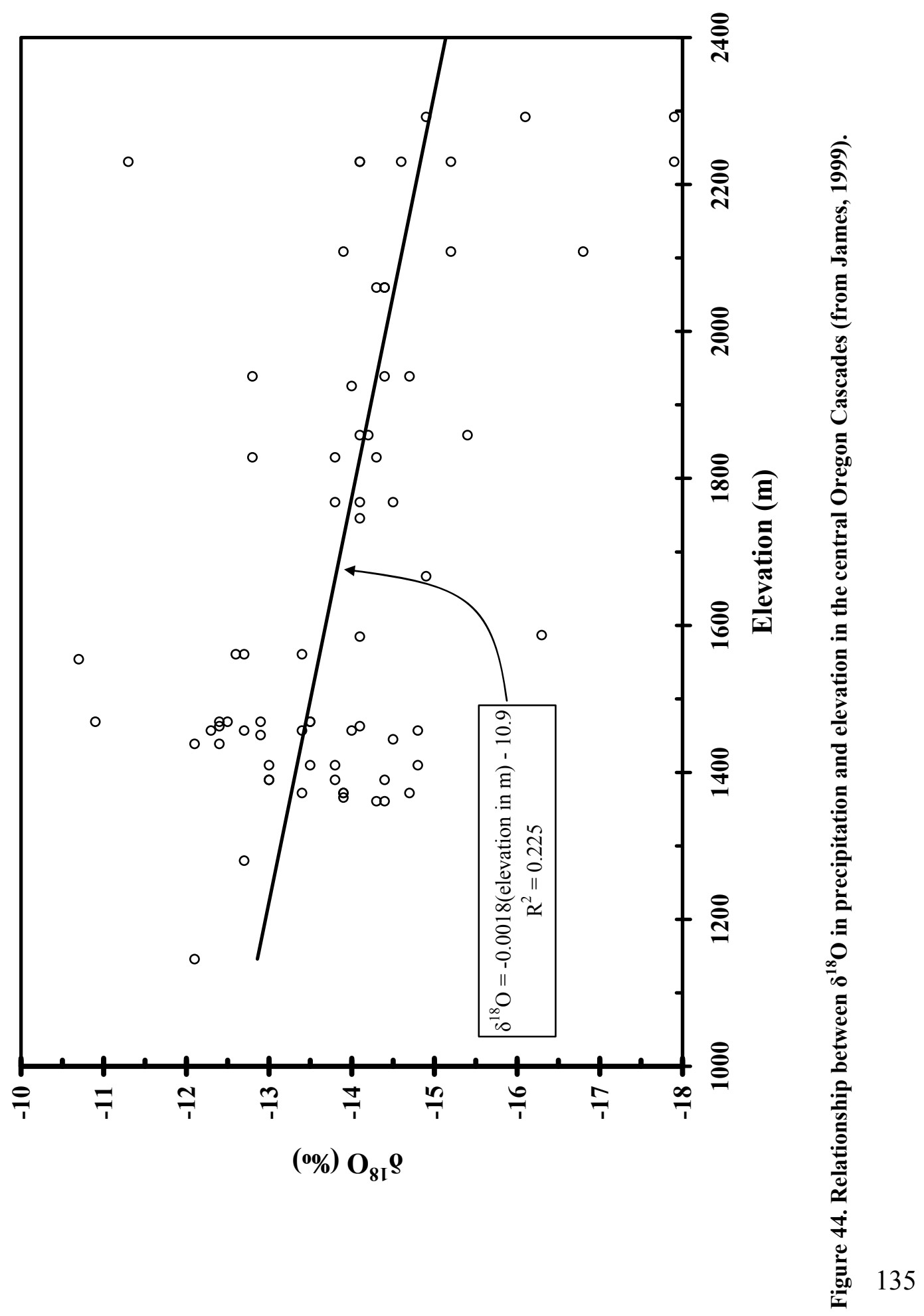


The local regression relationship between elevation and the oxygen isotopic composition of precipitation in the central Oregon Cascades determined by James (1999) was used to approximate recharge elevations of springs in the current study area. The recharge elevation was calculated by rearranging equation 11 to solve for elevation (equation 12). The inferred recharge elevation is viewed graphically by projecting the isotopic composition of the spring water to the elevation at which precipitation has a comparable composition to infer a representative or mean recharge elevation.

$$
\text { Elevation }(m)=\frac{-\left(\delta^{18} O+10.9\right)}{0.0018}
$$

Recharge elevation estimates for springs sampled during the current study and the Lower Opal Springs sample from Caldwell (1998) are presented in Table 20 and Figure 45. Due to uncertainties related to scatter in the precipitation data (Figure 44), calculated recharge elevations are rounded to the nearest 50 meters. Estimated recharge elevations are lowest for Camp Polk Springhouse, Anderson Springs, and Paulina Spring, and are highest for Lower Opal Springs, Alder Springs, and Metolius Spring. Estimated recharge elevations for the McKinney Butte Springs are considerably higher than elevations for the Camp Polk Springs and Paulina Spring, but are not quite as high as recharge elevations for Metolius, Alder, and Lower Opal Springs. 
Table 20. Spring recharge elevations estimated from the relationship between $\delta^{18} O$ in precipitation and elevation on the east flank of the central Oregon Cascades.

\begin{tabular}{lcc}
\multicolumn{1}{c}{ Spring } & $\begin{array}{c}\text { Discharge } \\
\text { Elevation (m) }\end{array}$ & $\begin{array}{c}\text { Recharge } \\
\text { Elevation (m) }\end{array}$ \\
\hline Frank Springs & 929 & $1800-1900$ \\
Chester Springs & 930 & 1900 \\
Anderson Springs & 945 & 1300 \\
Camp Polk Springhouse & 942 & $950-1200$ \\
Paulina Spring & 1024 & 1250 \\
Alder Springs & 695 & 2300 \\
Metolius Spring & 914 & 2150 \\
Lower Opal Springs (Caldwell, 1998) & 597 & 2450 \\
\hline
\end{tabular}

In several cases, inferred recharge elevations for springs coincide with local topographic highs. For example, the inferred recharge elevation for Paulina Spring (1250 m) suggests that recharge occurs on nearby topographic highs Fivemile Butte, Graham Butte, or Sixmile Butte, that have maximum elevations of 1231,1280 , and $1391 \mathrm{~m}$, respectively. In fact, Paulina Spring discharges from the toe of a Quaternary basaltic andesite flow that originated on Fivemile Butte (Basalt of Fivemile Butte; from Sherrod et al., 2004). Possible recharge locations for Anderson Springs and Camp Polk Springhouse (inferred recharge elevations of $1250 \mathrm{~m}$ and 950-1200 m) include the same locations as for Paulina Spring, the flanks of Black Butte, or lower elevations on the east flank of Trout Creek Butte. As was the case with Paulina Spring, possible recharge locations for Anderson Springs and Camp Polk Springhouse are found near the springs, within a distance of approximately $10 \mathrm{~km}$ or less. The proximity of the recharge and discharge areas for these springs suggests they discharge local-scale groundwater flow. 


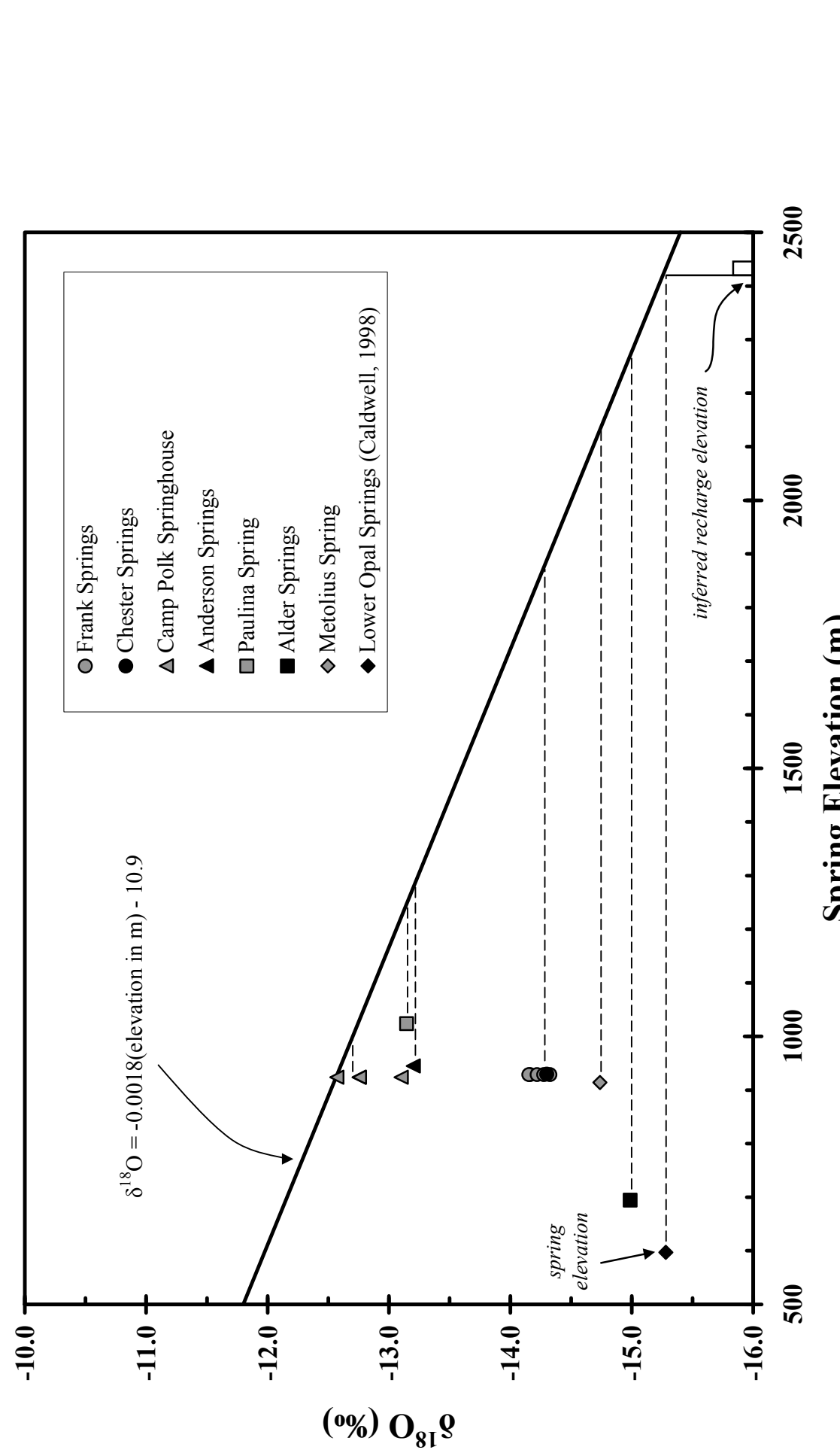

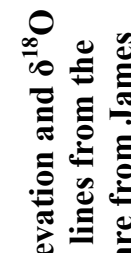

ฮ

递㻤

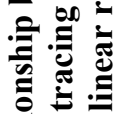

종

家

起

施

जิ

ఏ

อ

들

ฮ)

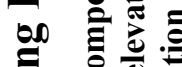

至

两

鞄

ฮ를

育离屵

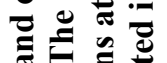

$\dot{\bar{\theta}} \dot{\mathrm{s}}$

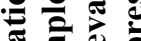

远苛

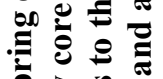

के है

๘

它哥

实

娄远

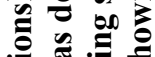

సै

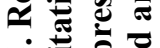

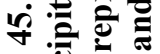

记

然 
Metolius Spring, which is found at an elevation of $914 \mathrm{~m}$, has an inferred recharge elevation of $2150 \mathrm{~m}$. Possible recharge locations include Mt. Washington and Belknap Crater, approximately $25-30 \mathrm{~km}$ from the spring. Alder Springs is also recharged at high elevations near the Cascades crest, over $40 \mathrm{~km}$ from the discharge point. James (1999) found the recharge elevation for Lower Opal Springs, a spring that is found at an elevation of $597 \mathrm{~m}$ in the regional discharge area, ranged from 2450$2600 \mathrm{~m}$. Potential recharge locations include the Three Sisters or other high elevation peaks along the Cascade crest, nearly $50 \mathrm{~km}$ from the spring. These observations suggest that Metolius Spring, Alder Springs, and Lower Opal Springs (referred to as the Regional Springs when the discussion applies to all) are all part of the regional groundwater flow system.

Similar to the Regional Springs, inferred recharge elevations for the McKinney Butte Springs (1800-1900 m for Frank Springs and $1900 \mathrm{~m}$ for Chester Springs) are also much higher than their discharge elevations (Table 20). However, the McKinney Butte Springs recharge elevations are slightly lower than those for the Regional Springs, suggesting the locus of their recharge occurs on the flanks of the Cascades, but not at the crest.

A second interpretation is that discharge from the McKinney Butte Springs is a mixture of recharge from high elevations near the crest of the Cascades (recharge elevations similar to those for the Regional Springs) and from more local, lower elevation areas (recharge elevations similar to those for Paulina Spring and the Camp Polk Springs). A simple mixing model was employed to calculate the fractions of 
regional- and local-scale groundwater flow that would be discharged from the McKinney Butte Springs in this scenario (equation 13).

$$
\delta^{18} O_{M B S}=f_{P S}\left(\delta^{18} O_{P S}\right)+f_{L O S}\left(\delta^{18} O_{L O S}\right)
$$

Where $\delta^{18} O_{M B S}, \delta^{18} O_{P S}$, and $\delta^{18} O_{L O S}$ are the $\delta^{18} \mathrm{O}$ values (\%) in the McKinney Butte Springs, Paulina Spring, and Lower Opal Springs and $f_{P S}$ and $f_{L O S}$ are the fraction of flow in the McKinney Butte Springs that is provided by local- $\left(f_{P S}\right)$ and regional- $\left(f_{L O S}\right)$ scale groundwater flow.

The mixing model assumes that $\delta^{18} \mathrm{O}$ values in Paulina Spring and Lower Opal Springs represent endmembers for local and regional recharge areas, respectively. $\delta^{18} \mathrm{O}$ values used in the model were $-14.2 \%$ for the McKinney Butte Springs, $-13.1 \%$ for Paulina Spring and $-15.28 \%$ for Lower Opal Springs. Solving equation 13 gives values of 0.5 for $f_{P S}$ and 0.5 for $f_{L O S}$. Thus, according to the model, $50 \%$ of the discharge from the McKinney Butte Springs is provided by regional-scale groundwater flow and $50 \%$ is supplied by local-scale groundwater.

Local-scale groundwater flow is typically more susceptible to short-term variations in recharge, which suggests discharge from springs whose source is locally recharged groundwater should display seasonal variations. This is true for the Camp Polk Springs which had visibly higher discharges during winter 2008 than during June and September 2007. If local-scale groundwater flow is supplying a significant fraction of the discharge in the McKinney Butte Springs, seasonal variations in the isotopic composition of the springs might be expected. For example, if $f_{P S}$ in equation 13 is reduced to 0.30 , the $\delta^{18} \mathrm{O}$ value in the McKinney Butte Springs would be reduced 
to $-14.6 \%$. However, $\delta^{18} \mathrm{O}$ concentrations measured in the McKinney Butte Springs six times during a 16 -month period varied by only $0.1 \%$ (Table 12 ). This lack of seasonal variation suggests either the contribution of local-scale discharge is insignificant or, less likely, that seasonal variations in the magnitude of local-scale groundwater flow are minimal.

The shallow aquifer on the west side of McKinney Butte is comprised of highly permeable glacial outwash sediments and High Cascade lavas that have filled a depositional basin created by down-to-the-west displacement along a normal fault bounding the west side of the butte (Figure 5). Groundwater in the high permeability outwash and High Cascade lavas is juxtaposed against lower permeability upper Miocene to Pliocene Deschutes Formation strata that form and underlie McKinney Butte. Evidence of this is the flattening of the hydraulic gradient that occurs in the Sisters area (Figure 26). The water table elevation in the glacial outwash and High Cascade lavas, $940-945 \mathrm{~m}$, is very similar to the elevations of Anderson Springs (945 m) and Camp Polk Springhouse (942 m). General chemistry and isotopic composition of these springs indicate they are supplied by local-scale groundwater flow. Seasonal variations in the height of the water table will impact discharge from the springs by altering the hydraulic gradient. During times when the water table is low, the gradient between the water table and the Camp Polk Springs will be lower, and discharge, which is proportional to the gradient, will be diminished. Because the elevations of the Camp Polk Springs are within a few meters of the water table, seasonal fluctuations in water table elevation will substantially affect discharge from the springs. 
In contrast, the elevations of the McKinney Butte Springs $($ Chester Springs $=$ $930 \mathrm{~m}$ and Frank Springs $=929 \mathrm{~m})$ are 10-15 $\mathrm{m}$ lower than the local water table. If shallow groundwater is supplying some of the discharge from these springs, the seasonal variation should be less than in the Camp Polk Springs due to the greater elevation difference between the water table and the springs. Less seasonal variation in discharge would also result in less seasonal variation in $\delta^{18} \mathrm{O}$ values in the McKinney Butte Springs.

\section{Temperature}

Circulating groundwater transports heat. If groundwater flow velocities are sufficiently large, most of the subsurface heat will be transported by advection (Manga and Kirchner, 2004). Such is the case in the central Oregon Cascades, where highly permeable near-surface rocks permit high recharge rates and thus high groundwater flow rates. The result is that most background geothermal heat is transported advectively by groundwater and discharged at springs (Manga and Kirchner, 2004). Therefore, the temperature of spring water can be used to infer the geothermal heat flux. However, not all springs have been warmed geothermally, as deeply circulating groundwater acquires more geothermal heat than groundwater that circulates to shallow depths (James et al., 2000). Thus, temperature measurements at springs are another means of assessing the relative scale of groundwater flow.

Several investigators have used water temperatures in springs to examine the geothermal heat flux from the central Oregon Cascades (i.e., Ingebritsen et al., 1989, 
1992, 1994; Blackwell and Priest, 1996; James, 1999; James et al., 2000; Manga, 1998; Manga and Kirchner, 2004). Many of these studies have attributed the temperature increase $(\Delta T)$ in groundwater from the recharge area to the discharge area entirely to geothermal warming (Ingebritsen et al., 1989, 1992, 1994; Blackwell and Priest, 1996; James, 1999; James et al., 2000; Manga, 1998) However, recent work by Manga and Kirchner (2004) has demonstrated that temperature increase due to the conversion of gravitational potential energy (GPE) to heat is important in settings where the difference in elevation between the recharge and discharge areas is sufficiently large $(\sim 1 \mathrm{~km})$, and conductive heat transfer with the Earth's surface contributes to $\Delta T$ when the water table depth is less than a few meters. Manga and Kirchner (2004) calculated a GPE lapse rate of $2.3{ }^{\circ} \mathrm{C} / \mathrm{km}$ using equation 14 :

$$
\frac{\Delta T}{\Delta z}=\frac{g}{C_{w}}
$$

where $g$ is gravitational acceleration $\left(9.8 \mathrm{~m} / \mathrm{s}^{2}\right)$, and $C_{w}$ is the specific heat of water $\left(4186 \mathrm{~J} / \mathrm{kg}^{\circ} \mathrm{C}\right)$. The assumptions associated with determining $\Delta T$ are: 1$)$ groundwater recharge enters the subsurface at temperatures near the mean annual surface temperature of the recharge area, and 2) the temperature of the aquifer is uniform across its thickness. Additionally, heat conduction to and from the Earth's surface can generally be ignored in the central Oregon Cascades because aquifer depths are typically greater than many tens of meters (e.g. Gannett, et al., 2003; cited in Manga and Kirchner, 2004). 
Temperature corrections for GPE dissipation in study area springs are provided in Table 21. Figure 46a shows water temperature of a spring as a function of the discharge elevation, and Figure 46b shows the relationship between spring temperatures corrected for GPE dissipation and recharge elevation obtained from oxygen isotope analysis. The plus signs show the mean annual surface temperature as a function of elevation at seven climate stations in or near the current study area for the period from 1961-1990 (Oregon Climate Service, 2008) (Table 22). The dashed lines in Figure 46 bracket the range of expected surface temperatures as a function of elevation. The scatter of climate station temperatures probably reflects local climate variations that are influenced by various mountain chains in the region (Manga and Kirchner, 2004). The temperature change $(\Delta T)$ attributed to geothermal warming is shown in Figure 46b.

Table 21. Temperatures of study area springs corrected for gravitational potential energy dissipation (GPE).

\begin{tabular}{lcccc}
\hline \multicolumn{1}{c}{ Name } & $\begin{array}{c}\text { Elevation } \\
(\mathbf{m})\end{array}$ & $\begin{array}{c}\text { Temperature } \\
\left({ }^{\circ} \mathbf{C}\right)\end{array}$ & $\begin{array}{c}\text { Recharge } \\
\text { Elevation } \\
(\mathbf{m})\end{array}$ & $\begin{array}{c}\text { Temperature } \\
\text { Corrected for GPE } \\
\left({ }^{\circ} \mathbf{C}\right)\end{array}$ \\
\hline Frank Spring & 929 & 8.9 & 1849 & 6.8 \\
Anderson Springs & 945 & 7.9 & 1278 & 7.1 \\
Camp Polk Springhouse & 942 & 9.3 & 1053 & 9.0 \\
Paulina Spring & 1024 & 4.3 & 1248 & 3.8 \\
Metolius Spring & 914 & 8.9 & 2132 & 6.1 \\
Alder Springs & 695 & 10.5 & 2271 & 6.9 \\
Lower Opal Springs (Caldwell, 1998) & 597 & 12.0 & 2433 & 7.8 \\
\hline
\end{tabular}


Table 22. Mean annual surface temperatures at climate stations in the region for the period from 1961-1990.

\begin{tabular}{lcc}
\hline Station Name & Elevation (m) & $\begin{array}{c}\text { Mean Annual } \\
\text { Temperature }\left({ }^{\circ} \mathbf{C}\right)\end{array}$ \\
\hline Santiam Pass & 1448 & 4.28 \\
Sisters & 969 & 7.67 \\
Bend & 1116 & 7.89 \\
Wickiup & 1329 & 6.56 \\
Chemult & 1451 & 5.67 \\
Crater Lake NP & 1972 & 3.11 \\
Metolius & 762 & 8.67 \\
\hline
\end{tabular}

The water temperature of most springs is similar to the mean annual surface temperature at the discharge elevation (Figure 46a). Frank Springs, Metolius Spring, Alder Springs, and Lower Opal Springs discharge water that is several degrees warmer than the mean recharge temperature (Figure 46b). The amount of geothermal warming in each spring is $2.0,2.6,4.05$, and $5.7^{\circ} \mathrm{C}$ for Frank Springs, Metolius Spring, Alder Springs, and Lower Opal Springs, respectively. Geothermal warming in these springs suggests they discharge deep groundwater flow.

A linear relationship exists between recharge elevation and spring temperature for the Regional Springs, where spring temperature increases $0.56^{\circ} \mathrm{C}$ for every $100 \mathrm{~m}$ gain in recharge elevation (Figure 46b). Frank Springs, however, does not follow the trend of the Regional Springs (Figure 46b). The reason for the linear trend could be related to relative flow path depths of groundwater discharged at each of the springs. Locally, for waters that circulate to the deep part of the aquifer system, recharge elevation is related to groundwater flow paths, where the groundwater circulation depth increases with increasing recharge elevation. This is due to the fact that the majority of recharge occurs at high elevations, which is the major driving force for 
groundwater flow in the study area. Water that circulates deeper, and as a result closer, to geothermal heat sources could have slightly elevated temperatures relative to groundwater that has followed shallower flow paths. The reason Frank Springs, despite showing some geothermal warming, does not follow the linear trend is uncertain, but could be explained by a shallow groundwater component of spring discharge.

In contrast to the previously mentioned springs that discharge water with several degrees of geothermal warming, Paulina Spring and Anderson Springs discharge water that shows no evidence of geothermal warming (Figure 46b). Camp Polk Springhouse discharges water that is $0.5^{\circ} \mathrm{C}$ warmer than the mean annual surface temperature at the inferred recharge elevation, but this could be attributed to local climate variations. High concentrations of anthropogenically influenced ions and low estimated recharge elevation suggest Camp Polk Springhouse discharges shallow groundwater flow and supports the argument that it does not discharge water that has been geothermally warmed.

As discussed in the Stable Isotopes section of this chapter, Frank Springs may discharge a mixture of local- and regional-scale groundwater. The potential impact on water temperature in Frank Springs where 50\% of the water is locally recharged and $50 \%$ is regional-scale groundwater was examined using equation 15 :

$$
f_{\text {CPSH }}\left(T_{C P S H}\right)+f_{R S G W}\left(T_{R S G W}\right)=T_{F S}
$$

where $f_{C P S H}$ and $T_{C P S H}$ are the fraction of flow from and temperature in Camp Polk Springhouse, and represent local-scale groundwater, $f_{R S G W}$ and $T_{R S G W}$ are the fraction 
of flow and temperature from regional-scale groundwater, and $T_{F S}$ is the water temperature in Frank Springs. The mean temperatures measured in Frank Springs and Camp Polk Springhouse were used for $T_{C P S H}\left(9.3^{\circ} \mathrm{C}\right)$ and $T_{F S}\left(8.9^{\circ} \mathrm{C}\right)$, respectively. A temperature of $8.5^{\circ} \mathrm{C}$ was calculated when equation 15 was solved for $T_{R S G W}$. Using an assumed recharge elevation of $2400 \mathrm{~m}, \Delta T$ due to GPE dissipation is $3.38^{\circ} \mathrm{C}$, leaving a GPE corrected temperature of $5.12^{\circ} \mathrm{C}$. The upper bound of mean annual surface temperature at $2400 \mathrm{~m}$ elevation is $2.22{ }^{\circ} \mathrm{C}$, and $\Delta T$ due to geothermal warming is $2.9^{\circ} \mathrm{C}$. This temperature is significant because it indicates that discharge from the McKinney Butte Springs is carrying geothermal heat.

Temperature in Anderson Springs is comparable to the mean annual surface temperature at the inferred recharge elevation, suggesting it does not discharge water that has been geothermally warmed. Temperature in Camp Polk Springhouse is slightly higher than expected at the inferred recharge elevation, but can be explained by climatic variations that occur in the region (Manga and Kirchner, 2004). Temperature data from the Camp Polk Springs aligns with previously presented general chemistry and stable isotope data and indicates that they discharge shallow groundwater that is recharged locally and at low elevations. 

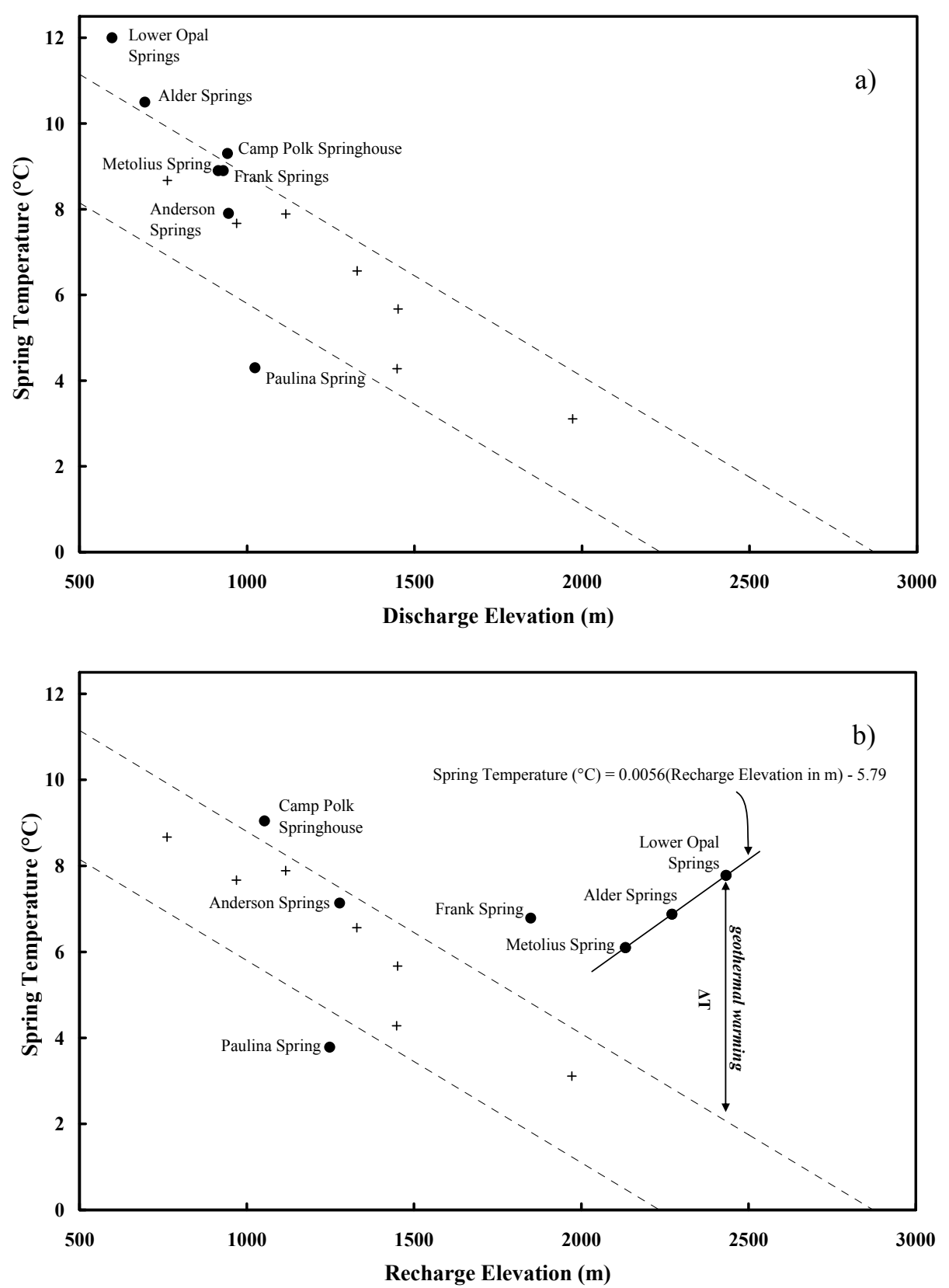

Figure 46. Relationship between elevation and water temperature in study area springs. The plus signs show the mean annual surface temperature at climate stations in the region and the dashed lines show the upper and lower bounds of the relationship between elevation and surface temperature (data from Oregon Climate Service). (a) Spring temperature as a function of discharge elevation. (b) Spring temperature as a function of the mean recharge elevation inferred from oxygen isotope content of the spring water. Spring temperatures in (b) are corrected for the expected $2.3^{\circ} \mathrm{C} / \mathrm{km}$ increase in water temperature as the water flows to lower elevations. The temperature difference $\Delta T$ indicates the amount of geothermal warming of the water. The Regional Springs (Lower Opal Springs, Alder Springs, and Metolius Spring) show a linear relationship between temperature and inferred recharge elevation. 
The McKinney Butte Springs discharge water that contains geothermal heat, a sign of deeper groundwater circulation. This is in agreement with previously presented major ion and stable isotope data that also suggest regional-scale groundwater is a major component of discharge from the McKinney Butte Springs. However, as was the case with the stable isotope data, the temperature data does not eliminate the potential contribution from shallow, local-scale groundwater flow.

\section{Conceptual Model of Groundwater Flow}

In general, the factors controlling groundwater flow through the study area are the same as those operating throughout the upper Deschutes Basin. These include the distribution of recharge and the physical characteristics of geologic units through which the water is moving. Geologic structures, principally faults and fault zones, influence groundwater flow by affecting patterns of sediment deposition, by juxtaposing rocks of contrasting permeability and by providing preferential flow paths for the upward migration of deeply circulating groundwater.

The area of greatest recharge is along the slopes of the Cascade Range to the west of the study area with lesser amounts of recharge occurring on volcanic centers bordering the study area to the north and south. The high recharge along the slopes of the Cascades results from a combination of heavy precipitation and high infiltration through young Quaternary volcanic deposits. Groundwater then moves towards discharge areas east of the study area under a topographic gradient. 


\section{Horizontal Groundwater Flow}

In the upper Deschutes Basin, groundwater follows many flowpaths from highelevation recharge areas along the slopes the Cascades toward low-elevation discharge areas near the confluences of the Deschutes, Crooked, and Metolius Rivers (Gannett, et al., 2001). Groundwater flow through the study area largely follows the same paths although some groundwater surfaces as springs on the east side of McKinney Butte. Water level contour maps indicate that horizontal gradients in shallow and deep parts of the flow system are high in the recharge areas to the west of the study area, decrease in the vicinity of McKinney Butte and the city of Sisters, and then increase again east of the butte (Figures 26 and 27).

The water table elevation immediately west of McKinney Butte is relatively high given its position in the basin (Gannett et al., 2001) and the horizontal head gradient is low. These factors are controlled by the juxtaposition of highly permeable glacial outwash and intercalated High Cascade lavas against lower permeability Deschutes Formation material, which produces a "leaky dam" effect as groundwater is impounded on the west side. The high permeability of the outwash coupled with the fact that the shallow aquifer is unconfined also contributes to the low horizontal head gradient that is present on the west side of the butte.

East of McKinney Butte, the horizontal gradients in both the shallow and deep parts of the groundwater flow system increase dramatically (Figures 26 and 27). Two probable reasons for this increase include the distribution of precipitation in the study area, and the influence of local geologic faults. The McKinney Butte area is located to 
the east of a high gradient precipitation region where annual precipitation decreases from over $200 \mathrm{~cm} / \mathrm{yr}$ in the western part of the region to less than $40 \mathrm{~cm} / \mathrm{yr}$ approximately $4.5 \mathrm{~km}$ west of McKinney Butte (Figure 4). This reduction in precipitation, and consequently recharge, could play a part in the head gradient increase. The influence of faults on the head gradient increase is twofold. First, faults bounding McKinney Butte have juxtaposed higher permeability materials on the down-thrown (west) side against lower permeability materials on the up-thrown (east) side. The decrease in permeability east of the faults may be accommodated by an increase in horizontal head gradient. Second, the shallow, saturated, higher permeability materials that provide downward leakage to deeper parts of the flow system west of the faults are not present on the east side. The lack of leakage from shallow water-bearing zones east of McKinney Butte may also contribute to the gradient increase in the deep part of the groundwater flow system.

Both the spatial distribution of precipitation and the factors related to faulting in the McKinney Butte area are potential explanations for the horizontal head gradient increase on the east side of McKinney Butte. However, the slope of the precipitation gradient begins flattening $4.5 \mathrm{~km}$ west of McKinney Butte (Figure 4; Figure 3 in Gannett et al., 2001) and is nearly flat from the butte to the eastern part of the basin, whereas, the initiation of the high horizontal head gradient zone and the faults bounding McKinney Butte are practically superimposed on one another (Figures 26 and 27). While both factors may contribute to the gradient increase on the east side of 
McKinney Butte, the available evidence suggests that the faults bounding the butte are the primary cause.

\section{Vertical Groundwater Flow}

The vertical hydraulic head gradient $(60 \mathrm{~m})$ between the shallow and deep parts of the flow system is greatest in the western part of the study area, where the locus of recharge occurs. The gradient decreases to approximately $15 \mathrm{~m}$ on the west side of McKinney Butte. The hydraulic head in both the shallow and deep parts of the system drop dramatically east of McKinney Butte. The paucity of shallow wells in the eastern part of the study area did not allow mapping of contours below an elevation of $900 \mathrm{~m}$ (Figure 26). However, the vertical gradient between shallow and deep flow zones is $15-30 \mathrm{~m}$ immediately east of the butte.

\section{Groundwater Flow to Camp Polk Springs}

Discharge from Camp Polk Springs is supplied by shallow groundwater. Losing reaches of Indian Ford Creek on the west side of McKinney Butte contribute to local shallow groundwater flow. Because shallow groundwater is the source of Camp Polk Springs, their discharge is controlled by the permeability contrast caused by local faulting. In fact, the springs probably owe their existence to the fault zone for two reasons. First, the depositional basin created on the west side of the fault was filled with highly permeable material, and second, the permeability contrast between the upthrown and downthrown sides of the fault essentially created a bathtub on the west side of McKinney Butte. Additionally, the lavas that form McKinney Butte are 
underlain by an ash-flow tuff of the Deschutes Formation (Tp in Figure 5). The lower permeability ash-flow tuff impedes downward leakage from the more permeable lavas and diverts groundwater flow laterally to the Camp Polk Springs. As a result of permeability contrasts between glacial outwash, the McKinney Butte lavas, and the Deschutes Formation ash-flow tuff, the saturated outwash and intercalated lavas west of McKinney Butte act as a head-dependent recharge boundary for the Camp Polk Springs.

\section{Groundwater Flow to the McKinney Butte Springs}

The McKinney Butte Springs discharge groundwater that is depleted in heavy isotopes of $\mathrm{O}$ and $\mathrm{H}$ and that is transporting geothermal heat. These factors suggest intermediate- or regional-scale groundwater supplies a substantial fraction of the flow to the springs. However, the McKinney Butte Springs are not as depleted in $\mathrm{O}$ and $\mathrm{H}$ isotopes as the Regional Springs, potentially indicating minor contribution from locally recharged, shallow groundwater flow that is enriched in isotopes of $\mathrm{O}$ and $\mathrm{H}$ relative to the Regional Springs.

Interpretation of the flow paths followed by groundwater that discharges from the McKinney Butte Springs is also complicated by the fact that the water is carrying geothermal heat. In the upper Deschutes Basin, groundwater carrying geothermal heat has been interpreted to circulate deep in the flow system (James, 1999; James et al., 2000; Gannett et al., 2003). The fact that water discharging from the springs carries 
geothermal heat indicates that upward migration of deep groundwater, presumably along local geologic faults, is occurring.

The low-permeability ash-flow tuff that impedes downward groundwater leakage from the shallow part of the system may also inhibit upward groundwater migration from the deeper part of the flow system and divert groundwater laterally to the McKinney Butte Springs. Evidence for this is provided on the driller's log for the Lamb Well (DESC 54659). On the log, sandstone is identified at a depth of $44.5 \mathrm{~m}$ below land surface. Well drillers working in the Deschutes Basin have commonly misidentified tuffs as sandstone (Lite, personal communication, 2011). Consequently, the sandstone recorded on the log is probably the same ash-flow tuff (Tp) shown on Figure 5. The water-bearing zone in the well occurs below the ash-flow tuff (49-58 $\mathrm{m}$ below land surface) and the average water level is approximately $30 \mathrm{~m}$ below land surface. The water level in the well is $19 \mathrm{~m}$ above the water-bearing zone indicating confined conditions. Confining pressures in the Lamb Well may indicate that the upward migration of groundwater is impeded locally by the low-permeability ash-flow tuff.

The McKinney Butte Springs occur along a southern extension of the structural trend that forms the eastern margin of the High Cascade graben and is responsible for the substantial amount of groundwater discharged at Metolius Spring. Previous research has shown that Metolius Spring contains geothermal heat, and magmatically derived carbon and helium-3 (James, 1999), indicating that water discharged at the spring has circulated deep in the groundwater flow system and migrated vertically up 
the Green Ridge fault escarpment (Gannett et al., 2003). The hydrochemical characteristics of the Metolius Spring sample analyzed during the current study are very similar to those of the McKinney Butte Springs. Water temperatures measured in Frank Springs and Metolius Spring in January 2008 were identical $\left(8.9^{\circ} \mathrm{C}\right.$, Table 11) and EC measured on the same date only differed by $1 \mu \mathrm{S} / \mathrm{cm}(62 \mu \mathrm{S} / \mathrm{cm}$ in Frank Spring and $63 \mu \mathrm{S} / \mathrm{cm}$ in Metolius Spring). Major ion and stable isotope concentrations in both springs are also very similar (Table 12). Additionally, both springs discharge water carrying geothermal heat (Table 21). The striking hydrochemical similarities between Metolius Spring and the McKinney Butte Springs and the fact that both occur in a part of the basin where regional-scale groundwater discharge is not expected suggest that the geologic factors controlling groundwater discharge at the springs are related, and that deep, regional-scale groundwater flow migrates vertically up faults bounding McKinney Butte and discharges from the McKinney Butte Springs.

The major difference between Metolius Spring and the McKinney Butte Springs is in the magnitude of their discharge. Discharge from Metolius Spring ranges from approximately $2-3 \mathrm{~m}^{3} / \mathrm{s}$ (Table 12 ) and is one order of magnitude greater than discharge from the McKinney Butte Springs $\left(\sim 0.20 \mathrm{~m}^{3} / \mathrm{s}\right.$, Table 17). Additionally, Metolius Spring discharges a substantial fraction of groundwater in a $400 \mathrm{~km}^{2}$ drainage basin, whereas the majority of groundwater in the McKinney Butte Spring's drainage basin discharges in the regional discharge area near the confluence of the Deschutes, Crooked, and Metolius Rivers and only a small fraction surfaces at the McKinney Butte Springs. 
The reason for the substantial difference in discharge between springs that occur along the same structural trend could be explained by differences in the size of the faults that occurs near each spring. Metolius Spring occurs along the Green Ridge fault, which has experienced at least $1 \mathrm{~km}$ of down-to-the-west displacement (Sherrod et al., 2004). In contrast, vertical offset on the Tumalo fault at McKinney Butte is less than $100 \mathrm{~m}$ (Sherrod et al., 2004). The greater offset at Green Ridge may provide more preferential pathways for the upward movement of deeply circulating groundwater than at McKinney Butte.

\section{Conceptual Groundwater Flow Model}

The conceptual model presented here considers the interpretations from horizontal and vertical groundwater flow presented previously in this section as well as interpretations from the Source of McKinney Butte and Camp Polk Springs section presented earlier in this chapter. A cross section of the proposed conceptual model is presented in Figure 47.

Groundwater supplying the McKinney Butte Springs is recharged high on the flanks of the Cascades, follows deep flow paths, and flows upward along preferential pathways provided by the faults bounding McKinney Butte where it discharges from the McKinney Butte Springs. Local and regional scale groundwater may mix near McKinney Butte; and if this occurs, the regional-scale portion of flow is interpreted to be recharged at very high elevations in the Cascades. If the proposed conceptual model properly describes groundwater flow through the study area, upward head 
gradients must occur near McKinney Butte. As shown in Figures 26 and 27, upward head gradients were not identified in the study area. In fact, with the exception of a limited zone in the regional discharge area near the confluence of the Deschutes, Crooked, and Metolius Rivers, upward head gradients have not been encountered in the upper Deschutes Basin (Gannett et al., 2001). The lack of observed upward gradients in the study area does not preclude their existence, as they may be limited to a laterally narrow zone that is not penetrated by many wells. As previously discussed, confining pressures in the Lamb Well may indicate upward groundwater flow locally. However, only one water-bearing zone was encountered in the well, so vertical gradients could not be identified. Although upward gradients were not observed, the gradient decrease on the east edge of McKinney Butte indicates the convergence of shallow and deep groundwater flow paths. 


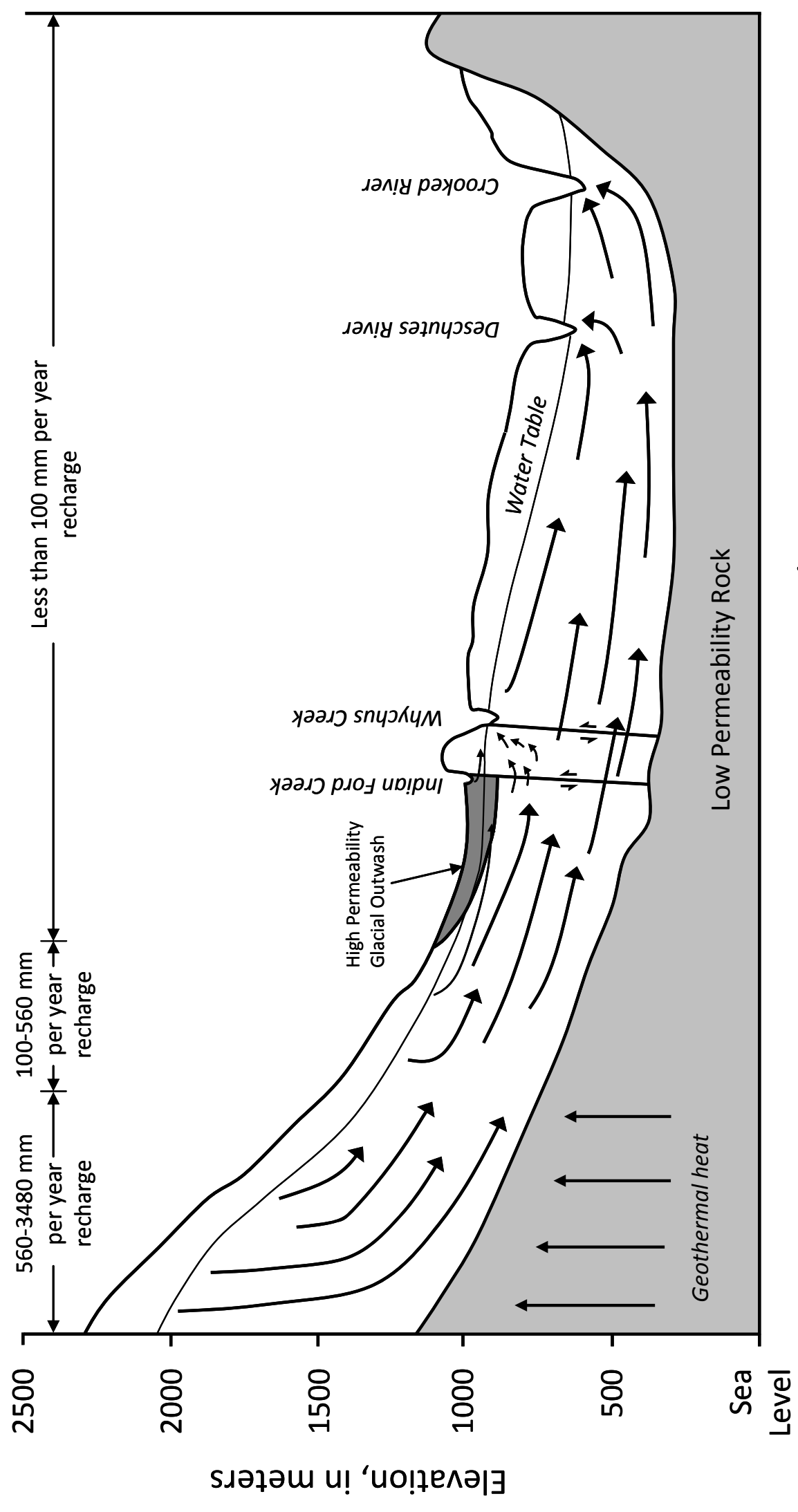

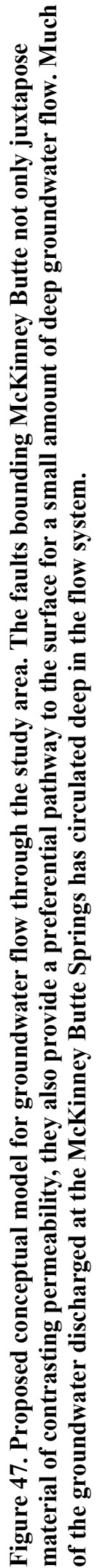




\section{Chapter 7 - Summary and Conclusions}

This study has investigated the hydrologic and geochemical characteristics of springs and streams in the McKinney Butte area of the upper Deschutes Basin in order to gain an understanding of the local hydrologic system and examine the effects the McKinney Butte Springs have on Whychus Creek. In particular this study had the following objectives: 1) quantify the magnitude and seasonal variation of flow from the McKinney Butte Springs; 2) quantify the relative contribution of the spring flow to the total flow of Whychus Creek on a seasonal basis; 3) determine the thermal impact of spring flow on Whychus Creek; 4) identify the source(s) of spring water via the hydrochemistry of the McKinney Butte Springs and local surface waters; and 5) develop a conceptual groundwater-flow model that accounts for the spatial and temporal distribution of discharge, hydraulic head, chemistry, and temperature within the geologic framework of the area.

Discharge from the McKinney Butte Springs was estimated via seepage runs on Whychus Creek, and mixing models that employed electrical conductivity (EC) and temperature data measured in the springs and Whychus Creek. Uncertainty associated with each method was quite large and ranged from $28 \%$ to $66 \%$ for seepage runs, $26 \%$ to $31 \%$ for electrical conductivity, and $16 \%$ for temperature. However, discharge calculated via each method were generally in agreement and a likely range for discharge from the McKinney Butte Springs is $0.10-0.30 \mathrm{~m}^{3} / \mathrm{s}$. Little seasonal variation in the McKinney Butte Springs was discernable. Estimated discharge from 
seepage runs varied from $0.141 \mathrm{~m}^{3} / \mathrm{s}$ on $06 / 25 / 2007$ to $0.201 \mathrm{~m}^{3} / \mathrm{s}$ on $01 / 30 / 2008$, a total variation of $0.06 \mathrm{~m}^{3} / \mathrm{s}$, while even less variation was estimated from $\mathrm{EC}$ and temperature data.

The contribution of discharge from the McKinney Butte Springs to Whychus Creek was estimated on daily and monthly bases from $01 / 2006$ to $02 / 2008$. Estimated monthly contributions ranged from $3-7 \%$ during winter months and from $24-46 \%$ during later summer months. Daily contributions ranged from $1 \%$ to $59 \%$. These calculated contributions indicate discharge from the McKinney Butte Springs represents a significant fraction of flow in Whychus Creek during certain times of the year.

The McKinney Butte Springs discharge groundwater that has a stable temperature of approximately $9{ }^{\circ} \mathrm{C}$ and only varies by $\pm 0.3{ }^{\circ} \mathrm{C}$. As a result, the springs act as a thermal buffer locally. The thermal effect from the springs is greatest when discharge in Whychus Creek is low and when the temperature in the creek is either much greater or much less than the temperature of the springs. These two conditions are usually met in late summer, when creek temperatures are high. As mentioned in the Introduction Chapter, Whychus Creek is a ODEQ 303(d) listed stream for exceeding the maximum allowable temperature for salmon rearing and spawning. Because the McKinney Butte Springs lower temperature water, they potentially offer aquatic species thermal refuge during hot summer months. However, temperature regulation is also important in the winter; small fry were observed in the Frank 
Springs outflow channel in January 2008 when the spring temperature was $8.85^{\circ} \mathrm{C}$ and the temperature in Whychus Creek was $0.90{ }^{\circ} \mathrm{C}$.

Multiple scales of groundwater flow contribute to discharge from springs on McKinney Butte. Groundwater discharged at the McKinney Butte Springs was recharged at high elevations on the flanks of the Cascades and has experienced some geothermal warming, indicating it has circulated deeper in the groundwater flow system than water discharged from the Camp Polk Springs. However, shallow groundwater may contribute to discharge from the McKinney Butte Springs. Additionally, general chemistry indicates the springs show little to no effect of anthropogenic sources. Conversely, water discharged from the Camp Polk Springs, located 2-3 km downstream, was recharged at lower elevations, shows no signs of geothermal warming, and has elevated concentrations of the anthropogenically influenced ions $\mathrm{NO}_{3}, \mathrm{SO}_{4}$, and $\mathrm{Cl}$.

The occurrence of springs along McKinney Butte is controlled by faulting related to the structural trend that forms the eastern margin of the High Cascades graben. The Camp Polk Springs are the result of permeability contrasts between Pleistocene glacial outwash deposited in the down-dropped structural basin on the west side of the butte, Pliocene lavas that form McKinney Butte, and the Miocene ashflow tuff that underlies the butte. Groundwater flow through the outwash is impeded at the contact with less permeable McKinney Butte lavas, resulting in shallow water table elevations on the west side of the butte. Vertical groundwater flow through the McKinney Butte lavas is impeded by the less permeable ash-flow tuff that underlies 
the butte. As a result, groundwater flows laterally and discharges at the Camp Polk Springs.

A significant fraction of groundwater discharged at the McKinney Butte Springs has migrated vertically up faults of the Sisters fault zone that bound McKinney Butte. The hydrochemistry of the McKinney Butte Springs is very similar to Metolius Spring suggesting the same geologic mechanisms control groundwater discharge at both springs. The large difference in the amount of water discharging from Metolius Spring $\left(2-3 \mathrm{~m}^{3} / \mathrm{s}\right)$ and the McKinney Butte Springs $\left(\sim 0.20 \mathrm{~m}^{3} / \mathrm{s}\right)$ may be related to the size of the faults controlling their occurrence. Metolius Spring is located at the base of Green Ridge which has experienced at least $1 \mathrm{~km}$ of vertical displacement, while displacement on the Tumalo fault, which controls discharge from the McKinney Butte Springs is less than 100 m (Sherrod et al., 2004). 


\section{References Cited}

Allen, J.E., 1966, The Cascade Range volcano-tectonic depression of Oregon, in Transactions of the Lunar Geological Field Conference, Bend, Oregon, August 1965: Oregon Department of Mineral Industries, p. 21-43.

Armstrong, R.L., Taylor, E.M., Hales, P.O., and Parker, D.J., 1975, K-Ar dates for volcanic rocks, central Cascade Range of Oregon: Isochron/West, no. 13, p. 510.

Baldwin, E.M., 1981, Geology of Oregon (3rd ed.): Dubuque, Iowa, Kendall/Hunt Publishing Company, $170 \mathrm{p}$.

Black Butte Ranch, 2010, Black Butte Ranch fees and rates schedule 2010, http://filelibrary.myaasite.com/Content/2/2499/32183051.pdf, site accessed April 11, 2011.

Blackwell, D.D., and Priest, G.R., 1996, Rates and patterns of groundwater flow in the Cascade Range volcanic arc and the effect on subsurface temperatures:

Comment: Journal of Geophysical Research, v. 101, p. 17561-17568.

Bortolami, G.C., Ricci, B., Susella, G.F., Zuppi, G.M., 1978, Isotope hydrology of the Val Corsaglia, Maritime Alps, Piedmont, Italy, In: IAEA Staff (Editors), Isotope Hydrology, 1978, v. 1, IAEA, Vienna, p. 327-350.

Brown, J., Wyers, A., Aldous, A., and Bach, L., 2007, Groundwater and biodiversity conservation: a methods guide for integrating groundwater needs of ecosystems and species into conservation plans in the Pacific Northwest: The Nature Conservancy, $176 \mathrm{p}$.

Caldwell, R.R., and Truini, M., 1997, Ground-water and water-chemistry data for the upper Deschutes Basin, Oregon: U.S. Geological Survey Open-File Report 97$197,77 \mathrm{p}$.

Caldwell, R.R., 1998, Chemical study of regional ground-water flow and groundwater/surface-water interaction in the upper Deschutes Basin, Oregon: U.S. Geological Survey Water-Resources Investigations Report 97-4233, 49 p.

Camp, V.E., and Ross, M.E., 2004, Mantle dynamics and genesis of mafic magmatism in the intermontane Pacific Northwest: Journal of Geophysical Research, v. 109, B08204, doi:10.1029/2003JB002838, 2004.

Canter, L.W., and Knox, R.C., 1985, Septic tank system effects on ground water quality: Chelsea, Michigan, Lewis Publications, Inc., 336 p. 
Carter, R.W., and Anderson, I.E., 1963, Accuracy of current-meter measurements: American Society of Civil Engineers Journal, v. 97, no. HY4, p. 105-115.

Chitwood, L., 1999, One-year study of water quality in the Metolius Basin, Oregon, 1996-1997: Deschutes National Forest, 15 p.

Clark, I., 1987, Groundwater resources in the Sultanate of Oman: Origin, circulation times, recharge processes, and paleoclimatology: Unpublished doctoral thesis, Université de Paris-Sud, Orsay, France.

Clark, I., and Fritz, P., 1997, Environmental isotopes in hydrogeology: New York, Lewis Publishers, $352 \mathrm{p}$.

Clark, I.D., Fritz, P., Michel, F.A., and Souther, J.G., 1982, Isotope hydrology and geothermometry of the Mount Meager geothermal area: Canadian Journal of Earth Science, v. 19, p. 1454-1473.

Coleman, M.L, Shepherd, T.J., Durham, J.J., Rouse, J.E., and Moore, G.R., 1982, Reduction of water with zinc for hydrogen isotope analysis: Analytical Chemistry, v. 54, p. 993-995.

Conrey, R.M., 1985, Volcanic stratigraphy of the Deschutes Formation, Green Ridge to Fly Creek, North-Central Oregon. MS Thesis. Oregon State University, Corvallis, $349 \mathrm{p}$.

Craig, H., 1961, Isotopic variations in meteoric waters: Science, v. 133, p. 1702-1703.

Craig, H., and Gordon, L., 1965, Deuterium and Oxygen-18 variation in the ocean and the marine atmosphere, In: E. Tongiori (Ed.), Stable Isotopes in Oceanographic Studies and Paleotemperatures, Spoleto, 1965.

Cramer, S.P., and Beamesderfer, R.C.P., 2006, Population dynamics, habitat capacity, and a life history simulation model for steelhead in the Deschutes River, Oregon. Prepared for PGE, Portland, OR. Prepared by S.P. Cramer \& Associates, Inc. Portland, OR. 195 p.

Criss, R.E., 1999, Principles of Stable Isotope Distribution: New York, Oxford University Press, $254 \mathrm{p}$.

De Loach, R.J.H., 1921, Fertilizers for golf courses: Bulletin of Green Section of United States Golf Association, v. 1, no. 9, p. 186-187.

Draper, D.S., 1991, Late Cenozoic bimodal magmatism in the northern Basin and Range Province of southeastern Oregon: Journal of Volcanology and Geothermal Research, v. 47, p. 299-328. 
DuBois, J.D., and Flück, J., 1984, Utilization of geothermal resources of the Baden area: Swiss National Energy Foundation, NEFF 165-1B-032, Basel.

Easterbrook, D.J., 1986, Stratigraphy and chronology of Quaternary deposits of the Puget Lowland and Olympic Mountains of Washington and the Cascade Mountains of Washington and Oregon in Sibrava, V., Bowen, D.Q., and Richmond, G.M., eds., Quaternary glaciations in the northern hemisphere: Oxford, Pergamon Press, p. 145-159.

Epstein S., and Mayeda, T., 1953, Variation of ${ }^{18} \mathrm{O}$ content of waters from natural sources: Geochimica et Cosmochimica Acta, v. 4, p. 213-224.

Evans, W.C., Mariner, R.H., Ingebritsen, S.E., Kennedy, B.M., van Soest, M.C., and Huebner, M.A., 2002, Report of hydrologic investigations in the Three Sisters area of central Oregon, summer 2001: U.S. Geological Survey WaterResources Investigations Report 02-4061, 13 p.

Evans, W.C., van Soest, M.C., Mariner, R.H., Hurwitz, S., Ingebritsen, S.E., Wicks Jr., C.W., Schmidt, M.E., 2004, Magmatic intrusion west of Three Sisters, central Oregon, USA: the perspective from spring geochemistry: Geology, v. 32; no. 1; p. 69-72.

Faure, G., 1986, Principles of isotope geology (2nd ed.): New York, Wiley, 589 p.

Fontes, J., and Olivry, J.C., 1977, Gradient istopique entre 0 et $4000 \mathrm{~m}$ dans les précipitations du Mount Cameroun: Comtes Redus Réunion Annuelle Sciences de la Terre, Société géologie française, Paris.

Friedman, E., Benson, C., Gleason, J., Warden, A., and Harris, J.M., 1992, Stable isotope composition of waters in southeastern California 1. Modern precipitation: Journal of Geophysical Research, v. 97, p. 5795-5812.

Friedrichsen, P.T., 1996, Summertime stream temperatures in the north and south forks of the Sprague River, South Central Oregon. MS thesis. Oregon State University, Corvallis, $147 \mathrm{p}$.

Gannett, M.W., and Lite, K.E., Jr., 2004, Simulation of regional ground-water flow in the upper Deschutes Basin, Oregon: U.S. Geological Survey Water-Resources Investigations Report 03-4195, $84 \mathrm{p}$.

Gannett, M.W., Lite, K.E., Jr., Morgan, D.S., and Collins, C.A., 2001, Ground-water hydrology of the upper Deschutes basin, Oregon: U.S. Geological Survey Water-Resources Investigations Report 00-4162, 77 p. 
Gannett, M.W., Manga, M., and Lite, K.E., Jr., 2003, Groundwater hydrology of the upper Deschutes Basin and its influence on streamflow, In: A Peculiar River: Geology, Geomorphology, and Hydrology of the Deschutes River, Oregon, Water Science and Application Series, vol. 7, edited by J.E. O'Conner and G.E. Grant, p. 31-49, American Geophysical Union, Washington, D.C.

Hem, J.D., 1985, Study and interpretation of the chemical characteristics of natural water: U.S. Geological Survey Water Supply Paper 2254, 263 p.

Henshaw, F.F., Lewis, J.H., and McCaustland, E.J., 1914, Deschutes River, Oregon, and its utilization: U.S. Geological Survey Water Supply Paper 344, 200 p.

Herschy, R.W., 1971, The magnitude of errors at flow measurement stations: Water Resources Board, Reading Bridge House, Reading, Berkshire, England, TN11, (Revised), $30 \mathrm{p}$.

Hildreth, W., 2007, Quaternary magmatism in the Cascades; geologic perspectives: U.S. Geological Survey Professional Paper 1744, 125 p.

Hinkle, S.R., Böhlke, J.K., Duff, J.H., Morgan, D.S., and Weick, R.J., 2007, Aquiferscale controls on the distribution of nitrate and ammonium in ground water near LaPine, Oregon, USA: Journal of Hydrology, v. 333, p. 486-503.

Hughes, S.S., and Taylor, E.M., 1986, Geochemistry, petrogenesis, and tectonic implications of central High Cascade mafic platform lavas: Geological Society of America Bulletin, v. 97, p. 1024-1036.

Ingebritsen, S.E., Mariner, R.H., Cassidy, D.E., Shepherd, L.D., Presser, T.S., Pringle, M.K.W., and White, L.D., 1988, Heat-flow and water-chemistry data from the Cascade Range and adjacent areas in North-Central Oregon: U.S. Geological Survey Open-File Report 88-702, 205 p.

Ingebritsen, S.E., Sherrod, D.R., and Mariner, R.H., 1989, Heat flow and hydrothermal circulation in the Cascade Range volcanic arc, and the effect of subsurface temperatures: Journal of Geophysical Research, v. 97, p. 45994627.

Ingebritsen, S.E., Sherrod, D.R., and Mariner, R.H., 1992, Rates and patterns of groundwater flow in the Cascade Range volcanic arc, and the effects on subsurface temperature: Journal of Geophysical Research, v. 97, p. 4599-4627.

Ingebritsen, S.E., Mariner, R.H., and Sherrod, D.R., 1994, Hydrothermal systems of the Cascade Range, north-central Oregon, U.S. Geological Survey Professional Paper 1044-L, 86 p. 
Ingraham, N.L., Lyles, B.F., Jacobsen, R.L., and Hess, J.W., 1991, Stable isotope study of precipitation and spring discharge in southern Nevada: Journal of Hydrology, v. 125, p. 243-258.

Jacob, H., and Sonntag, C., 1991, An 8-year record of the seasonal variation of ${ }^{2} \mathrm{H}$ and ${ }^{18} \mathrm{O}$ in atmospheric water vapor and precipitation in Heidelberg, Germany: Tellus, v. 43, p. 291-300.

James, E.R., 1999. Isotope tracers and regional-scale groundwater flow: application to the Oregon Cascades. MS thesis. University of Oregon, Eugene, 150 p.

James, E.R., Manga, M., and Rose, T.P., 1999, $\mathrm{CO}_{2}$ degassing in the Oregon Cascades: Geology, v. 27, no. 9, p. 823-826.

James, E.R., Manga, M., Rose, T.P., and Hudson, G.B., 2000, The use of temperature and the isotopes of $\mathrm{O}, \mathrm{H}, \mathrm{C}$, and noble gases to determine the pattern and spatial extent of groundwater flow: Journal of Hydrology, v. 237, p. 100-112.

Kendall, C., and McDonnell, J., 1998, Isotope tracers in catchment hydrology: Amsterdam, The Netherlands, Elsevier Science B.V., 839 p.

Lite, K.E., Jr., and Gannett, M.W., 2002, Geologic Framework of the Regional Ground-Water Flow System in the Upper Deschutes Basin, Oregon: U.S. Geological Survey Water-Resources Investigations Report 02-4015, 44 p.

Manga, M., 1996, Hydrology of spring-dominated streams in the Oregon Cascades: Water Resources Research, v. 32, no. 8, p. 2435-2439.

Manga, M., 1997, A model for discharge in spring-dominated streams and implications for the transmissivity and recharge of Quaternary volcanics in the Oregon Cascades: Water Resources Research, v. 33, p 1813-1822.

Manga, M., 1998, Advective heat transport by low-temperature discharge in the Oregon Cascades: Geology, v. 26, p. 799-802.

Manga, M., 2001, Using springs to study groundwater flow and active geologic processes: Annual Review of Earth and Planetary Science, v. 29, p. 201-228.

Manga, M., and Kirchner, J.W., 2004, Interpreting the temperature of water at cold springs and the importance of gravitational potential energy: Water Resources Research, v. 40, W05110, doi:10.1029/2003WR002905, 8 p.

McClaughry, J.D., Gordon, C.L., and Ferns, M.L., 2009a, Field trip guide to the middle Eocene Wildcat Mountain caldera, Ochoco National Forest, Crook County, Oregon: Oregon Geology, v. 69, no. 1, p. 5-24. 
McClaughry, J.D., Ferns, M.L., Gordon, C.L., and Patridge, K.A., 2009b, Field trip guide to the Oligocene Crooked River caldera, central Oregon's supervolcano, Crook, Deschutes, and Jefferson Counties, Oregon: Oregon Geology, v. 69, no. 1, p. 25-44.

Meinzer, O.E., 1927, Large springs in the United States: U.S. Geological Survey Water Supply Paper 557, 94 p.

Moser, H., and Stichler, W., 1970, Deuterium measurements on snow samples from the Alps, In: Isotope Hydrology 1970, IAEA Symposium 129, Vienna.

O'Connor, J.E., Grant, G.E., and Haluska, T.L., 2003, Overview of geology, Hydrology, geomorphology, and sediment budget of the Deschutes River Basin, Oregon, In: A Peculiar River: Geology, Geomorphology, and Hydrology of the Deschutes River, Oregon, Water Science and Application Series, vol. 7, edited by J.E. O'Conner and G.E. Grant, p. 9-31, American Geophysical Union, Washington, D.C.

Oregon Climate Service, 2008, Oregon Climate Data, http://www.ocs.orst.edu/oregonclimate-data, Site accessed January through May 2008.

Oregon DEQ, 2007, Water quality limited streams 303(d) list, http://www.deq.state.or.us/wq/303dlist/303dpage.htm, Site accessed January 2007.

OWRD, 2011a, Oregon Surface Water Data, http://apps.wrd.state.or.us/apps/sw/misc_measurements_view_only/default.asp

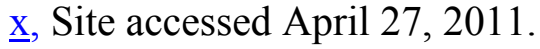

OWRD, 2011b, Water Rights Information Database (WRIS), http://www.wrd.state.or.us/OWRD/WR/wris.shtml, Site accessed April 14, 2011.

Peck, D.L., 1964, Geological reconnaissance of Antelope-Ashwood area, north-central Oregon: U.S. Geological Survey Bulletin 1161-D, p. D1-D26.

Pelletier, P.M., 1988, Uncertainties in the single determination of river discharge: a literature review: Canadian Journal of Civil Engineering, v. 15, no. 5, p. 834850 .

Perkin Elmer, 1994, Analytical Methods for Atomic Absorption Spectrometry: The Perkin Elmer Corporation, Manual Part No. 0303-0152, release C, 300 p. 
Priest, G.R., 1990, Volcanic and tectonic evolution of the Cascade volcanic arc, central Oregon: Journal of Geophysical Research, v. 95, no. B12, p. 19,58315,999 .

Rantz, S.E., 1982, Measurement and computation of streamflow: volume 1. measurement of stage and discharge: U.S. Geological Survey Water Supply Paper 2175, $313 \mathrm{p}$.

Robinson, P.T., 1975, Reconnaissance geologic map of the John Day Formation in the southwestern part of the Blue Mountains and adjacent areas, north-central Oregon: U.S. Geological Survey Miscellaneous Geologic Investigations Map I-872, scale 1:125000.

Robinson, P.T., Brem, G.F., and McKee, E.H., 1984, John Day Formation of OregonA distal record of early Cascade volcanism: Geology, v. 12, no. 4, p. 229-232.

Rose, T.P., Davisson, M.L., and Criss, R.E., 1996, Isotope hydrology of voluminous cold springs in fractured rock from an active volcanic region, northeastern California: Journal of Hydrology, v. 179, p. 207-236.

Russell, I.C., 1905, Preliminary report on the geology and water resources of central Oregon: U.S. Geological Survey Bulletin 252, 138 p.

Sauer, V.B., and Meyer, R.W., 1992, Determination of error in individual discharge measurements: U.S. Geological Survey Open-File Report 92-144, 26 p.

Schneider, V.R., and Smoot, G.F., 1976, Development of a standard rating for the Price Pygmy current meter: U.S. Geological Survey Journal of Research, v. 4, no. 3, p. 293-297.

Siegenthaler, U., and Oescher, H., 1980, Correlation of 180 in precipitation with temperature and altitude: Nature, v. 285, p. 314-317.

Sherrod, D.R., Gannett, M.W., and Lite, K.E., Jr., 2002, Hydrogeology of the upper Deschutes Basin, central Oregon: A young basin adjacent to the Cascade volcanic arc, In: Field Guide to Geologic Processes in Cascadia: Oregon Department of Geology and Mineral Industries Special Paper 36, p. 109-144.

Sherrod, D.R., and Smith, J.G., 2000, Geologic map of upper Eocene to Holocene volcanic and related rocks of the Cascade Range, Oregon: U.S. Geological Survey Geologic Investigations Map I-2569, scale 1:500,000.

Sherrod, D.R., Taylor, E.M., Ferns, M.L., Scott, W.E., Conrey, R.M., and Smith, G.A., 2004, Geologic Map of the Bend 30- × 60-Minute Quadrangle, Central Oregon: U.S. Geological Survey Geologic Investigations Series Map I-2683. 
Smith, G.A., 1986, Stratigraphy, sedimentology, and petrology of Neogene rocks in the Deschutes Basin, central Oregon: A record of continental-margin volcanism and its influence on fluvial sedimentation in an arc-adjacent basin: $\mathrm{Ph} . \mathrm{D}$. dissertation Oregon State University, Corvallis, Oregon, 464 p.

Smith, G.A., 1991, A field guide to depositional processes and facies geometry of Neogene continental volcaniclastic rocks, Deschutes basin, central Oregon: Oregon Geology, v. 53, no.1, p. 3-20.

Smith, G.A., Snee, L.W., and Taylor, E.M., 1987, Stratigraphic, sedimentologic, and petrologic, record of late Miocene subsidence of the central Oregon High Cascades: Geology, v. 15, no. 5, p. 389-392.

Smoot, G.F., and Carter, R.W., 1968, Are individual current meter ratings necessary?: American Society of Civil Engineers Journal of the Hydraulics Division, 94 (HY2), p. 391-397.

Stanger, G., 1986, The hydrology of the Oman Mountains, Unpublished Ph.D. thesis, Open University, U.K.

Taylor, E.M., 1981, Central High Cascade roadside geology - Bend, Sisters, McKenzie Pass, and Santiam Pass, Oregon, in Johnston, D.A., and DonnellyNolan, J.M., eds., Guides to some volcanic terranes in Washington, Idaho, Oregon, and northern California: U.S. Geological Survey Circular-838, p. 5583.

Taylor, E.M., 1998, Geologic map of the Henkle Butte quad, Deschutes County, Oregon: Oregon Department of Geology and Mineral Industries Geological Map Series GMS-95, 5 p.

Taylor, E.M., in preparation, Geologic map of the Sisters quad, Deschutes County, Oregon, 1:24,000.

Taylor, E.M., and Ferns, M.L., 1994, Geology and mineral resources map of the Tumalo Dam quad, Deschutes County, Oregon: Oregon Department of Geology and Mineral Industries Geological Map Series GMS-81, 5 p., 2 pls., $1: 24,000$.

Taylor, E.M., and Ferns, M.L., 1995, Geologic map of the Three Creek Butte quad, Deschutes County, Oregon: Oregon Department of Geology and Mineral Industries Geological Map Series GMS-81, 5 p., 2 pls., 1:24,000.

Taylor, G.H., 1993, Normal annual precipitation, State of Oregon: Corvallis, Oregon State University, Oregon Climate Service, map. 
Tóth, J.A., 1963, A theoretical analysis of groundwater flow in small drainage basins: Journal of Geophysical Research, v. 68, no. 16, p. 4795-4812.

Waters, A.C., 1954, John Day formation west of its type locality [abs.]: Geological Society of America Bulletin, v. 65, p. 1320.

Weizu, G., and Longinelli, A., 1993, A case study on the hydrological significance of stable isotope data on alpine catchments with snow cover and glaciers, Xinjiang, China, In: Snow and Glacier Hydrology, Proceedings of the Kathmandu Symposium, IAHS Publication no. 218.

Wellik, J.M., 2008, Quaternary faulting of Deschutes County, Oregon: MS Thesis, Humboldt State University, Arcata, CA, 74 p.

YSI, 2002, YSI 556 MPS Multi Probe System Operations Manual: YSI Environmental, Yellow Springs, OH, 153 p. 


\section{Appendix A: Discharge Errors Discussion}

\section{Random Errors}

Seepage run measurements were obtained using the velocity-area method (Rantz, 1982; Sauer and Meyer, 1992). The velocity-area method of measurement includes observations of width, depth, and velocity taken at intervals in a cross section of a stream. Sauer and Meyer (1992) and Pelletier (1988) quantify and provide detailed discussions of the errors and uncertainties associated with the determination of river discharge via the velocity-area method. These errors include: 1) errors in cross sectional area, which relate to errors in measurement of width and depth, and errors in the assumption that the measured depth in a vertical represents the mean depth of a segment; 2) errors in mean stream velocity, which relate to current meter errors, vertical velocity distributions, velocity pulsations, and other factors; 3 ) errors associated with the computation method; and 4) errors caused by change in stage during the measurement, boundary effects, ice, obstructions, wind, incorrect equipment, incorrect measuring technique, poor distribution of the measurement verticals, carelessness, and other factors.

Theoretically, the true discharge would be an integration of the velocity and area throughout the cross section. In practice, however, the discharge is approximated by summing the products of the subsection areas of the stream cross section and their respective average velocities (equation A1).

$$
Q=\sum_{i=1}^{N}\left(b_{i} \times d_{i} \times v_{i}\right)
$$


Where, $Q$ is total calculated discharge $\left(\mathrm{m}^{3} / \mathrm{s}\right), N$ is the number of segments in the cross section, $b_{i}$ is the width of segment $i(\mathrm{~m}), d_{i}$ is the depth of segment $i(\mathrm{~m})$, and $v_{i}$ is the mean velocity in segment $i(\mathrm{~m} / \mathrm{s})$.

Velocities were measured with a current meter at discrete "verticals" (see below) across the width of the stream. The principal of operation of a current meter is based on the proportionality between the velocity of the water and the resulting angular velocity of the meter rotor. The velocity of water at a point in a stream is determined by counting the number of revolutions of the rotor during a measured interval of time. Price AA and Pygmy current meters were used during this study. These meters are used extensively by the USGS (Rantz, 1982). The Price AA meter has a rotor 5 inches $(0.127 \mathrm{~m})$ in diameter, while the Pygmy meter has a 2-inch $(0.051$ m) diameter rotor. The Pygmy's smaller diameter rotor more accurately measures velocity in shallow depths $(<0.46 \mathrm{~m})$. The Pygmy meter was used during most seepage runs conducted during this study; while the AA meter was only used, according to USGS standards, when the stream velocity was $>0.75 \mathrm{~m} / \mathrm{s}$ and the stream depth was greater than $0.46 \mathrm{~m}$ (these conditions were only met during the January 2008 seepage run on Whychus Creek). The current meters used in this study were calibrated in rating tanks prior to purchase.

A vertical is defined as the vertical line in which the depth and velocity measurements are made for the purpose of estimating the mean depth and mean velocity for a segment of the stream cross section. The segment extends, on each side, halfway to the adjacent vertical, if one exists, or all the way to the edge of the water. 
In each vertical, velocity is measured at one or two points to determine the average velocity in the vertical. Verticals are chosen so that flow in each segment of the streamflow measurement is approximately 5 percent or less of the total flow. This usually requires 25 to 30 verticals for each measurement (Sauer and Meyer, 1992).

Discharge measurements were performed following USGS guidelines presented in Rantz (1982). These guidelines, dictated by stream conditions, indicate the model of Price meter to be used, the amount of time necessary to determine the true velocity at each point in a vertical, the number of velocity measurements necessary to calculate the mean velocity at each vertical, and the number of verticals in each cross section. The Pygmy meter was used when the bulk of depths at a cross section were less than $0.46 \mathrm{~m}$, while the AA meter was used at depths greater than $0.46 \mathrm{~m}$. The AA meter was only used in the January 2008 seepage run on Whychus Creek when the majority of depths of verticals were greater than $0.46 \mathrm{~m}$. Rantz (1982) identified several common methods of determining the mean velocity at each vertical. Two common methods used by the USGS are the two-point and the six-tenths depth methods. In the two-point method, observations are made in each vertical at 0.2 and 0.8 of the depth below the surface. The average of those two observations is taken as the mean velocity in the vertical. When using the AA meter, the two-point method is not used at depths less than $0.76 \mathrm{~m}$ because the meter would then be too close to the water surface and to the streambed to give dependable results (Rantz, 1982). In the six-tenths depth method, an observation of velocity made in the vertical at 0.6 of the depth below the surface is used as the mean velocity in the vertical. The USGS uses 
the six-tenths depth method when a Pygmy meter is being used and the depth is between $0.09 \mathrm{~m}$ and $0.46 \mathrm{~m}$, or when an AA meter is being used and the depth is between $0.46 \mathrm{~m}$ and $0.76 \mathrm{~m}$ (Rantz, 1982). The depths in Whychus and Indian Ford creeks were such that the six-tenths depths method was used for all discharge measurements.

Two primary factors, width and depth, enter into the determination of the cross-section area. While width errors have been considered insignificant by most investigators (Sauer and Meyer, 1992), the uncertainty of making individual measurements of depth is considered significant. Errors in measuring depth are related to the composition of the streambed and the velocity of the stream. Uneven, rough streambeds (cobbles, rocks, boulders, etc.) can cause errors in measuring the true depth at each vertical. Depth measurements made with a rod in high velocities will produce "pile-up" of water on the rod at the water surface; if this is not accounted for, depth measurement errors will result. Sauer and Meyer (1992) present equations for determining standard errors for individual depth measurements made under several measuring conditions (Tables 1 and 2; Sauer and Meyer, 1992). Their measuring condition C (stable streambed with uneven gravel and cobbles) applies to the conditions in Whychus Creek, and condition B (soft streambed with silt, mud, and muck) applies to Indian Ford Creek conditions. Equations A2 and A3 are used to determine the approximate average standard error, in percent, attributable to individual depth measurement errors $\left(S_{d}\right)$ for conditions C and B. Sauer and Meyer (1992) indicate the measurement errors are highly subjective and arbitrary, but they conform 
as much as possible to information noted by previous investigators. Standard errors for condition $\mathrm{C}$ increase with decreasing depth and range from 3 percent at $1.22 \mathrm{~m}$ to 20 percent at $0.15 \mathrm{~m}$. Similarly, errors for condition B increase from 2.36 percent at 1.22 $\mathrm{m}$ to 10.36 percent at $0.15 \mathrm{~m}$.

$$
\begin{aligned}
& S_{d}=2 \sqrt{1+\left(\frac{3.048}{2 D}\right)^{2}} \\
& S_{d}=2 \sqrt{1+\left(\frac{1.524}{2 D}\right)^{2}}
\end{aligned}
$$

The primary sources of error for mean stream velocity are related to instrument errors, velocity pulsations, and vertical velocity distribution. These topics are covered by Smoot and Carter (1967), Schneider and Smoot (1976), and Carter and Anderson (1963).

Price AA and Pygmy meters were used to measure velocity. Studies by Smoot and Carter (1967) and Schneider and Smoot (1976) evaluated the error for the Price AA meter and the Price Pygmy meter, respectively. Smoot and Carter (1968) found no significant differences between new and used AA meters provided the meters were in good working order. They also found no difference between meters that were calibrated individually and meters calibrated in groups (referred to as standard calibration). The meters used in this study have undergone standard calibration. Their results indicate that for velocities greater than $0.7 \mathrm{~m} / \mathrm{s}$ instrument error is constant at about 0.3 percent. The standard errors for velocities from 0.076 to $0.69 \mathrm{~m} / \mathrm{s}$ appear to be logarithmically distributed and were thus used to define an equation (equation A4). 


$$
S_{i}=\frac{0.213}{V}
$$

Where $S_{i}$ is the instrument standard error, in percent, $V$ is the mean velocity, in $\mathrm{m} / \mathrm{s}$, and 0.213 is the regression constant. Instrument error for the Price pygmy current meter was evaluated by Schneider and Smoot (1976). Unlike results for the AA meter, they found that for most of the velocity range there is a significant difference between standard rated and individually rated Pygmy meters. However, new meters show about the same error characteristics as used meters. Additionally, their results show that for standard calibration in the range of velocities tested $(0.076$ to $0.91 \mathrm{~m} / \mathrm{s})$, velocities from 0.15 to $0.91 \mathrm{~m} / \mathrm{s}$ are logarithmically distributed and are represented by equation A5.

$$
S_{i}=1.258 V^{-0.3}
$$

Error calculated from equation 5 ranges from 2.22 percent at $0.15 \mathrm{~m} / \mathrm{s}$ to 1.29 percent at $0.91 \mathrm{~m} / \mathrm{s}$.

Water flowing in natural rivers and streams has a tendency to pulsate at any given point. An instantaneous measurement of velocity could be very different from the mean velocity at that point. Using data from 23 different rivers, Carter and Anderson (1963) showed that pulsation errors vary with time of exposure and with the observation depth. The errors are logarithmically distributed and are represented by equation A6 for the six-tenths depth method.

$$
S_{t}=16.6 T^{-0.28}
$$


Where, $S_{t}$ is the standard error, in percent, for pulsation error, and $T$ is the time of exposure, in seconds. Using equation A6, the standard pulsation error for $40 \mathrm{~s}$ of exposure time is 5.91 percent.

The determination of the mean velocity in a vertical is usually based on the six-tenths depth method or the two-point method. Carter and Anderson (1963) used data from 1,800 verticals taken at more than 100 stream sites to show that the standard error, $S_{r s}$, of the mean velocity in a vertical averaged about 11.2 percent for the sixtenths depth method, and 4.3 percent for the two-point method. They also developed equation $\mathrm{A} 7$ to compute the standard error due to error in the vertical velocity distribution over an entire cross section.

$$
S_{s}=\frac{S_{r s} \sqrt{1+(N-1) \bar{p}}}{\sqrt{N}}
$$

Where $S_{s}$ is the standard error, in percent, for the cross section, $S_{r s}$ is the standard error, in percent, for a single vertical as previously defined, $N$ is the number of verticals in the cross section, and $\bar{p}$ is the average correlation coefficient for a cross section. They defined the value of $\bar{p}$ as 0.04 . Substituting values for $S_{r s}$ and $\bar{p}$ in equation A7 yields the following equation for estimating $S_{s}$, the vertical velocity distribution error for an entire cross section, for the six-tenths depth method (equation A8). Inserting the number of verticals measured at each cross section during this study yields an error 3.14 percent at $N=25$.

$$
S_{s}=\sqrt{\frac{120.4}{N}+5.02}
$$


As previously discussed, a discharge measurement consists of measurements of depth and velocity at a number of verticals in a cross section, with discharge being computed for a segment represented by a vertical, or two adjacent verticals. For this study, discharge was calculated using the mid-section method. This method assumes the depth and velocity for a vertical applies to a sub-area (segment) extending halfway to the vertical on either side of the measured vertical. The assumption of linearity and/or uniformity of depth and velocity between verticals has been studied by a number of investigators including Carter and Anderson (1963) and Herschy (1971). Using data from these studies, Sauer and Meyer (1992) developed the following equation for the standard error related to horizontal distribution (equation A9).

$$
S_{v}=32 N^{-0.88}
$$

Where, $S_{v}$ is the standard error related to horizontal distribution, in percent, and $N$ is the number of verticals in a cross section. This equation indicates that $S_{v}$ is directly related to the number of verticals used for the discharge measurement. $S_{v}$ is 1.88 percent at $N=25$.

\section{Systematic Errors}

All of the uncertainties mentioned thus far have been random errors, meaning they can either be positive or negative and are randomly distributed throughout the discharge measurement. In addition to random errors, there is the possibility of systematic errors in the measurement of depth, width, and velocity. These are errors caused by improperly calibrated equipment, or improper use of such equipment, so 
that a systematic error (either positive or negative) is introduced. According to Sauer and Meyer (1992), most investigators have stated that systematic errors are small, generally less than 0.5 percent each for measurement of width, depth, and velocity. Therefore, the standard errors, as used in this study, are, $S_{s b}=0.5$ percent (for width), $S_{s d}=0.5$ percent (for depth), and $S_{s v}=0.5$ percent (for velocity).

The standard error, $S_{q}$, for an individual discharge measurement can be estimated by determining the individual component errors discussed in the preceding paragraphs and combining them into a root-mean square error as shown in equation A10.

$$
S_{q}=\sqrt{\left(\frac{\left(S_{d}^{2}+S_{t}^{2}\right)}{N}\right)+S_{i}^{2}+S_{s}^{2}+S_{v}^{2}+S_{s b}^{2}+S_{s d}^{2}+S_{s v}^{2}}
$$

This equation assumes that each of the error terms are independent of each other. It also assumes that the cross section is reasonably uniform so that the average values of depth and velocity can be used (Sauer and Meyer, 1992). The number of verticals, $N$, is used in equation 10 to account for the averaging effect of repeated measurements on errors caused by depth measurements $\left(S_{d}\right)$ and pulsation of velocity $\left(S_{t}\right)$. Each of the last three terms $S_{s b}, S_{s d}$, and $S_{s v}$, are assumed to be 0.5 percent, and can therefore have that value substituted in the equation. The resulting equation for estimating discharge error reduces to equation A11.

$$
S_{q}=\sqrt{\left(\frac{\left(S_{d}^{2}+S_{i}^{2}\right)}{N}\right)+S_{i}^{2}+S_{s}^{2}+S_{v}^{2}+0.75}
$$


Equation A11 was used to determine the percent error in individual measurements of discharge on Whychus and Indian Ford creeks. Measurement variables for each discharge measurement are presented in Table A1 and standard percent errors for each measurement are given in Table A2. 


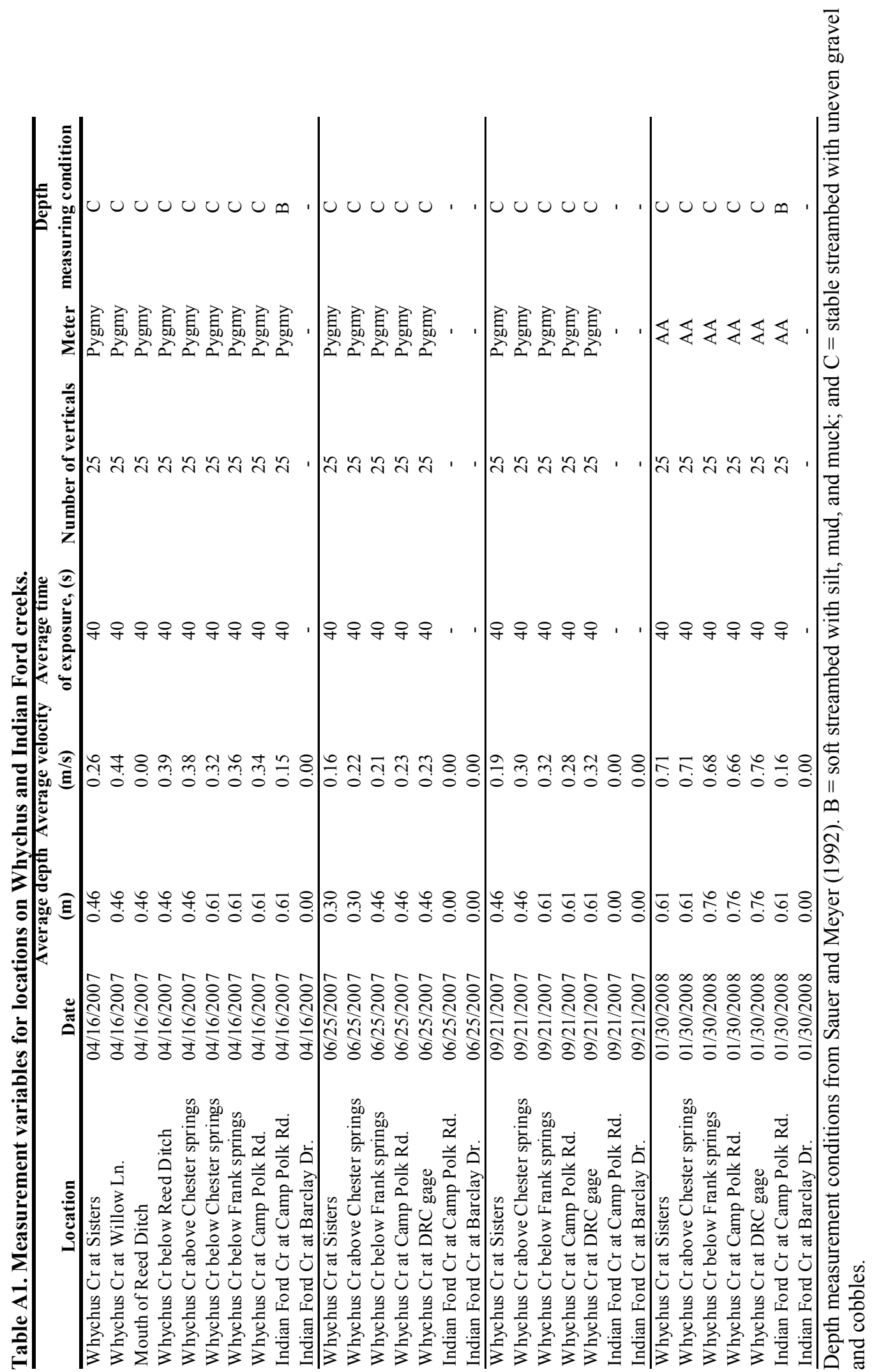


Table A2. Standard error, in percent, for discharge measurement locations on Whychus and Indian Ford creeks.

\begin{tabular}{|c|c|c|c|c|c|c|c|c|}
\hline Location & Date & $\mathbf{S}_{\mathbf{d}}$ & $S_{t}$ & $\mathbf{S}_{\mathbf{i}}$ & $\mathbf{S}_{\mathrm{s}}$ & $\mathbf{S}_{\mathbf{v}}$ & $S_{s b}+S_{s d}+S_{s v}$ & $\mathbf{S}_{\mathbf{q}}$ \\
\hline Whychus Cr at Sisters & $4 / 16 / 2007$ & 2.44 & 5.91 & 1.88 & 3.14 & 1.88 & 0.75 & 4.40 \\
\hline Whychus Cr at Willow Ln. & $4 / 16 / 2007$ & 2.44 & 5.91 & 1.61 & 3.14 & 1.88 & 0.75 & 4.28 \\
\hline Mouth of Reed Ditch & $4 / 16 / 2007$ & - & - & - & - & - & - & - \\
\hline Whychus Cr below Reed Ditch & $4 / 16 / 2007$ & 2.44 & 5.91 & 1.67 & 3.14 & 1.88 & 0.75 & 4.31 \\
\hline Whychus $\mathrm{Cr}$ above Chester springs & $4 / 16 / 2007$ & 2.44 & 5.91 & 1.68 & 3.14 & 1.88 & 0.75 & 4.31 \\
\hline Whychus Cr below Chester springs & $4 / 16 / 2007$ & 2.73 & 5.91 & 1.77 & 3.14 & 1.88 & 0.75 & 4.35 \\
\hline Whychus Cr below Frank springs & $4 / 16 / 2007$ & 2.73 & 5.91 & 1.71 & 3.14 & 1.88 & 0.75 & 4.33 \\
\hline Whychus Cr at Camp Polk Rd. & $4 / 16 / 2007$ & 2.73 & 5.91 & 1.74 & 3.14 & 1.88 & 0.75 & 4.34 \\
\hline Indian Ford $\mathrm{Cr}$ at Camp Polk Rd. & $4 / 16 / 2007$ & 2.21 & 5.91 & 2.22 & 3.14 & 1.88 & 0.75 & 4.55 \\
\hline Indian Ford $\mathrm{Cr}$ at Barclay Dr. & $4 / 16 / 2007$ & - & - & - & - & - & - & - \\
\hline Whychus $\mathrm{Cr}$ at Sisters & $6 / 25 / 2007$ & 2.20 & 5.91 & 2.18 & 3.14 & 1.88 & 0.75 & 4.53 \\
\hline Whychus $\mathrm{Cr}$ above Chester springs & $6 / 25 / 2007$ & 2.20 & 5.91 & 1.98 & 3.14 & 1.88 & 0.75 & 4.43 \\
\hline Whychus Cr below Frank springs & $6 / 25 / 2007$ & 2.44 & 5.91 & 2.01 & 3.14 & 1.88 & 0.75 & 4.45 \\
\hline Whychus Cr at Camp Polk Rd. & $6 / 25 / 2007$ & 2.44 & 5.91 & 1.96 & 3.14 & 1.88 & 0.75 & 4.43 \\
\hline Whychus Cr at DRC gage & $6 / 25 / 2007$ & 2.44 & 5.91 & 1.96 & 3.14 & 1.88 & 0.75 & 4.43 \\
\hline Indian Ford Cr at Camp Polk Rd. & $6 / 25 / 2007$ & - & - & - & - & - & - & - \\
\hline Indian Ford $\mathrm{Cr}$ at Barclay Dr. & $6 / 25 / 2007$ & - & - & - & - & - & - & - \\
\hline Whychus $\mathrm{Cr}$ at Sisters & $9 / 21 / 2007$ & 2.44 & 5.91 & 2.07 & 3.14 & 1.88 & 0.75 & 4.48 \\
\hline Whychus $\mathrm{Cr}$ above Chester springs & $9 / 21 / 2007$ & 2.44 & 5.91 & 1.81 & 3.14 & 1.88 & 0.75 & 4.36 \\
\hline Whychus Cr below Frank springs & $9 / 21 / 2007$ & 2.73 & 5.91 & 1.77 & 3.14 & 1.88 & 0.75 & 4.35 \\
\hline Whychus Cr at Camp Polk Rd. & $9 / 21 / 2007$ & 2.73 & 5.91 & 1.84 & 3.14 & 1.88 & 0.75 & 4.38 \\
\hline Whychus Cr at DRC gage & $9 / 21 / 2007$ & 2.73 & 5.91 & 1.77 & 3.14 & 1.88 & 0.75 & 4.35 \\
\hline Indian Ford Cr at Camp Polk Rd. & $9 / 21 / 2007$ & - & - & - & - & - & - & - \\
\hline Indian Ford $\mathrm{Cr}$ at Barclay Dr. & $9 / 21 / 2007$ & - & - & - & - & - & - & - \\
\hline Whychus $\mathrm{Cr}$ at Sisters & $1 / 30 / 2008$ & 2.73 & 5.91 & 1.39 & 3.14 & 1.88 & 0.75 & 4.22 \\
\hline Whychus $\mathrm{Cr}$ above Chester springs & $1 / 30 / 2008$ & 2.73 & 5.91 & 1.39 & 3.14 & 1.88 & 0.75 & 4.22 \\
\hline Whychus Cr below Frank springs & $1 / 30 / 2008$ & 3.06 & 5.91 & 1.41 & 3.14 & 1.88 & 0.75 & 4.23 \\
\hline Whychus Cr at Camp Polk Rd. & $1 / 30 / 2008$ & 3.06 & 5.91 & 1.43 & 3.14 & 1.88 & 0.75 & 4.24 \\
\hline Whychus $\mathrm{Cr}$ at DRC gage & $1 / 30 / 2008$ & 3.06 & 5.91 & 1.37 & 3.14 & 1.88 & 0.75 & 4.22 \\
\hline Indian Ford $\mathrm{Cr}$ at Camp Polk Rd. & $1 / 30 / 2008$ & 2.21 & 5.91 & 2.18 & 3.14 & 1.88 & 0.75 & 4.53 \\
\hline Indian Ford $\mathrm{Cr}$ at Barclay Dr. & $1 / 30 / 2008$ & - & - & - & - & - & - & - \\
\hline
\end{tabular}

\section{Stream Discharge Variation Errors}

Another potential source of error is variation in streamflow during the seepage run. Discharge from the McKinney Butte springs was determined from the difference in discharge at locations in Whychus Creek above and below the springs. Because spring discharge was determined indirectly from stream discharge measurements, any 
variation in stream discharge during the measurement period could produce erroneous spring discharge values. Variations in Whychus Creek discharge recorded every 15 minutes at the OWRD gage in Sisters were examined for the 12 hours prior to the start of each seepage run. The minimum discharge recorded by the OWRD gage during this time period was subtracted from the maximum recorded value to obtain the total variation. That value was divided by two to obtain the uncertainty due to variation in stream discharge during each seepage run. Errors due to variability in stream discharge $\left(E_{s v}\right)$, in $\mathrm{m}^{3} / \mathrm{s}$ are presented in Table A3.

Table A3. Error related to streamflow variability.

\begin{tabular}{|c|c|c|c|c|}
\hline Date & $\begin{array}{c}\text { Minimum Q } \\
\left(\mathrm{m}^{3} / \mathrm{s}\right)\end{array}$ & $\begin{array}{c}\text { Maximum Q } \\
\left(\mathrm{m}^{3} / \mathrm{s}\right)\end{array}$ & $\begin{array}{c}\text { Total Variablity } \\
\left(\mathrm{m}^{3} / \mathrm{s}\right)\end{array}$ & $\begin{array}{c}\text { Error, } E_{s v} \\
\left(\mathrm{~m}^{3} / \mathrm{s}\right)\end{array}$ \\
\hline $04 / 16 / 2007$ & 0.554 & 0.572 & 0.018 & 0.009 \\
\hline $06 / 25 / 2007$ & 0.238 & 0.288 & 0.050 & 0.025 \\
\hline $09 / 21 / 2007$ & 0.359 & 0.412 & 0.053 & 0.027 \\
\hline $01 / 30 / 2008$ & 1.792 & 1.832 & 0.040 & 0.020 \\
\hline
\end{tabular}

The total error at each measurement site $\left(E_{t}\right)$, in $\mathrm{m}^{3} / \mathrm{s}$, was calculated by multiplying the standard error at each site, $S_{q}$, by the measured discharge $Q$, and dividing by 100 , then adding the error due to streamflow variability, $E_{s v}$ :

$$
E_{t}=\left(\frac{S_{q} \times Q}{100}\right)+E_{s v}
$$

Discharge from the McKinney Butte springs was calculated using data from measurement sites upstream and downstream from the springs. Because spring discharge was calculated with data from two measurement sites, its error was calculated using equation $\mathrm{A} 13$, where $E_{s}$ is spring discharge error, in $\mathrm{m}^{3} / \mathrm{s}, e_{a c}$ is the calculated discharge error at the measurement site above Chester springs, in $\mathrm{m}^{3} / \mathrm{s}$, and 
$e_{b f}$ is the calculated discharge error at the measurement site below Frank springs, in $\mathrm{m}^{3} / \mathrm{s}$. The total uncertainty for each measurement site and for calculated spring discharge is presented in the Results from Current Study section of Chapter 4.

$$
E_{s}=\sqrt{e_{a c}^{2}+e_{b f}^{2}}
$$




\section{Appendix B: General Chemistry Error Discussion}

Anion and cation concentrations were measured in the Portland State University Trace Element Analytical Laboratory using a Dionex Model 2500 ion chromatograph and a Perkin Elmer AAnalyst 300 atomic absorption spectrometer, respectively. Quality control samples - laboratory blanks and check standards - were analyzed prior to analyzing samples and repeated after every 10 samples to monitor accuracy and precision. A summary of analytical error is presented in Table B1 for anion analysis and in Table B2 for cation analysis. Two errors and a minimum reporting limit are presented. The first (Accuracy Error) was determined by analysis of known standards and the second (Precision Error) represents one standard deviation from replicate samples. The minimum reporting limit was determined from ion concentrations measured in sample blanks and is reported as two standard deviations greater than the mean concentration in the blanks. A minimum reporting limit is not presented for cation analysis because concentrations in all samples were at least two orders of magnitude greater than concentrations in field blanks. Total error for each sample, calculated using equation B1 is presented in Table B3.

$$
E_{T}=E_{A C}+\left(\left(1.96 *\left(\frac{E_{p}}{C_{\text {sample }}}\right)\right) * 100\right)
$$

Where $E_{T}$ is the total error (\%), $E_{A C}$ is Accuracy Error (\%), $E_{p}$ is Precision Error (mg/L), and $C_{\text {sample }}$ is the measured analyte concentration in the sample $(\mathrm{mg} / \mathrm{L})$. 
Silica concentrations were measured in the Portland State University Trace Element Analytical Laboratory using a Beckman Coulter DU 730 ultraviolet visible spectrophotometer (UV-Vis). Total percent error presented in Table B3 represents two standard deviations from the mean concentration based on triplicate analysis.

Table B1. Accuracy and precision errors associated with anion analysis.

Accuracy Precision Min. Reporting

Ion $\operatorname{Error}(\%)$ Error (mg/L) Limit (mg/L)

\begin{tabular}{lccc}
\hline \multicolumn{4}{c}{ Sept. and Nov. 2006 Samples } \\
\hline $\mathrm{F}$ & 1.49 & 0.0015 & 0.0000 \\
$\mathrm{Cl}$ & 4.38 & 0.0053 & 0.0520 \\
$\mathrm{NO}_{3}$ & 5.25 & 0.0018 & 0.0167 \\
$\mathrm{SO}_{4}$ & 3.62 & 0.0007 & 0.0107 \\
$\mathrm{PO}_{4}$ & 34.30 & 0.0095 & 0.3511 \\
\hline \multicolumn{4}{c}{ April 2007 Samples } \\
\hline $\mathrm{F}$ & 4.40 & 0.0019 & 0.0000 \\
$\mathrm{Cl}$ & 3.32 & 0.0008 & 0.0000 \\
$\mathrm{NO}_{3}$ & 8.50 & 0.0000 & 0.0000 \\
$\mathrm{SO}_{4}$ & 3.72 & 0.0015 & 0.0227 \\
$\mathrm{PO}_{4}$ & 34.12 & 0.0029 & 0.2239 \\
\hline \multicolumn{4}{c}{ June Aug., and Sept. 2007 Samples } \\
\hline $\mathrm{Cl}^{4}$ & 4.29 & 0.0035 & 0.0000 \\
$\mathrm{NO}_{3}$ & 2.69 & 0.0010 & 0.0591 \\
$\mathrm{SO}_{4}$ & 6.02 & 0.0056 & 0.0868 \\
$\mathrm{PO}_{4}$ & 4.32 & 0.0031 & 0.0185 \\
\hline & 27.67 & 0.0036 & 0.2215 \\
\hline $\mathrm{F}$ & January 2008 Samples \\
$\mathrm{Cl}$ & 5.34 & 0.0010 & 0.0000 \\
$\mathrm{NO}_{3}$ & 9.26 & 0.0063 & 0.0399 \\
$\mathrm{SO}_{4}$ & 7.98 & 0.0919 & 0.1389 \\
$\mathrm{PO}_{4}$ & 33.93 & 0.0095 & 0.0000 \\
\hline & \multicolumn{4}{c}{. } & & 0.2685 \\
\hline
\end{tabular}


Table B2. Accuracy and precision errors associated with cation analysis.

\begin{tabular}{lcc}
\hline Ion & $\begin{array}{c}\text { Accuracy } \\
\text { Error }(\%)\end{array}$ & $\begin{array}{c}\text { Precision } \\
\text { Error }(\mathbf{m g} / \mathbf{L})\end{array}$ \\
\hline \multicolumn{2}{l}{ Sept. and } & Nov. 2006 Samples \\
$\mathrm{Ca}$ & 5.26 & 0.0038 \\
$\mathrm{~K}$ & 2.40 & 0.0144 \\
$\mathrm{Mg}$ & 2.19 & 0.0082 \\
$\mathrm{Na}$ & 5.40 & 0.0227 \\
\hline April, June, & Aug., and Sept., 2007 Samples \\
\hline $\mathrm{Ca}$ & 7.51 & 0.0180 \\
$\mathrm{~K}$ & 2.63 & 0.0071 \\
$\mathrm{Mg}$ & 4.77 & 0.0291 \\
$\mathrm{Na}$ & 4.62 & 0.0093 \\
\hline January 2008 Samples & \\
\hline $\mathrm{Ca}$ & 10.99 & 0.1400 \\
$\mathrm{~K}$ & 1.43 & 0.0040 \\
$\mathrm{Mg}$ & 0.70 & 0.0191 \\
$\mathrm{Na}$ & 4.76 & 0.0182 \\
\hline
\end{tabular}




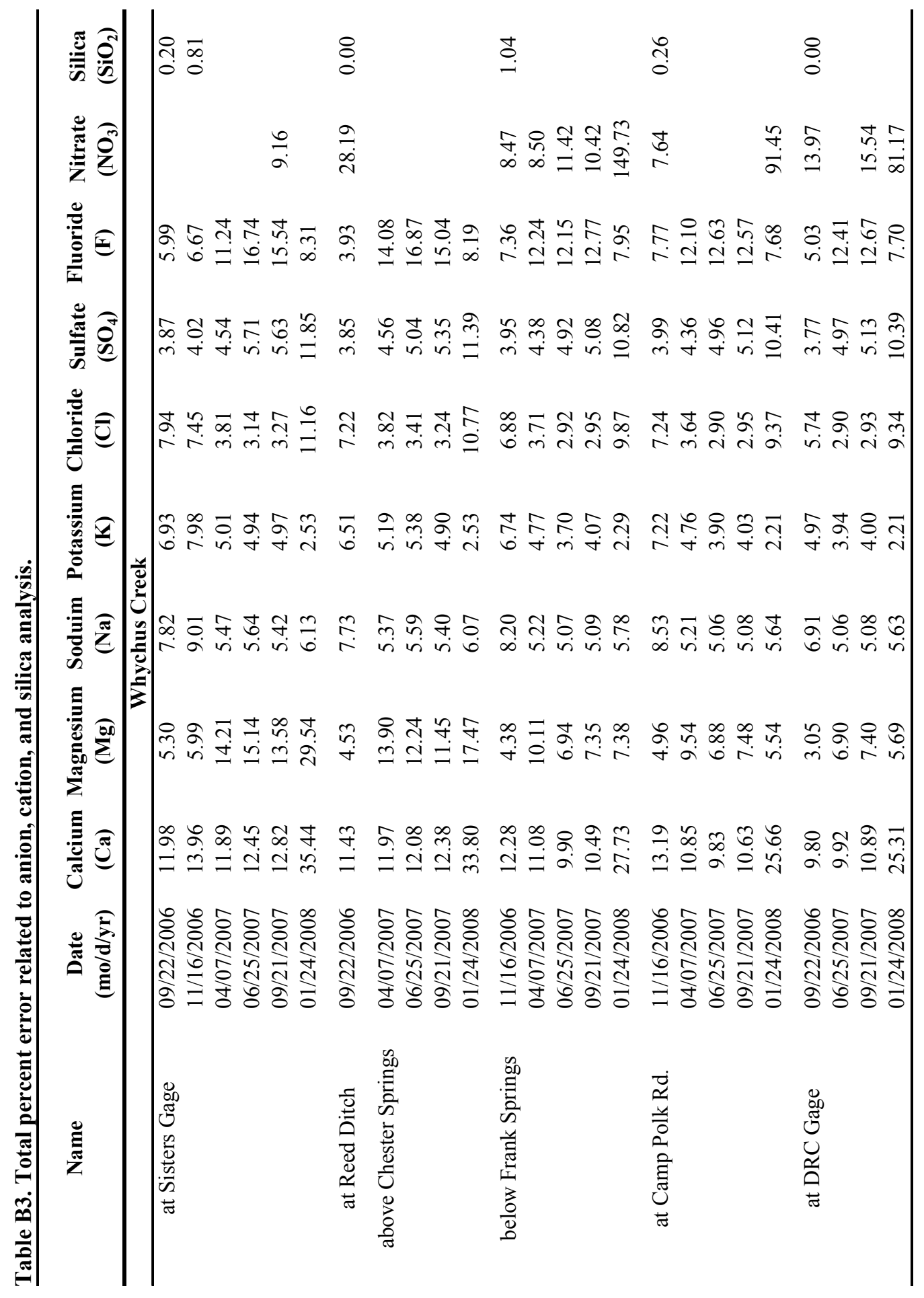




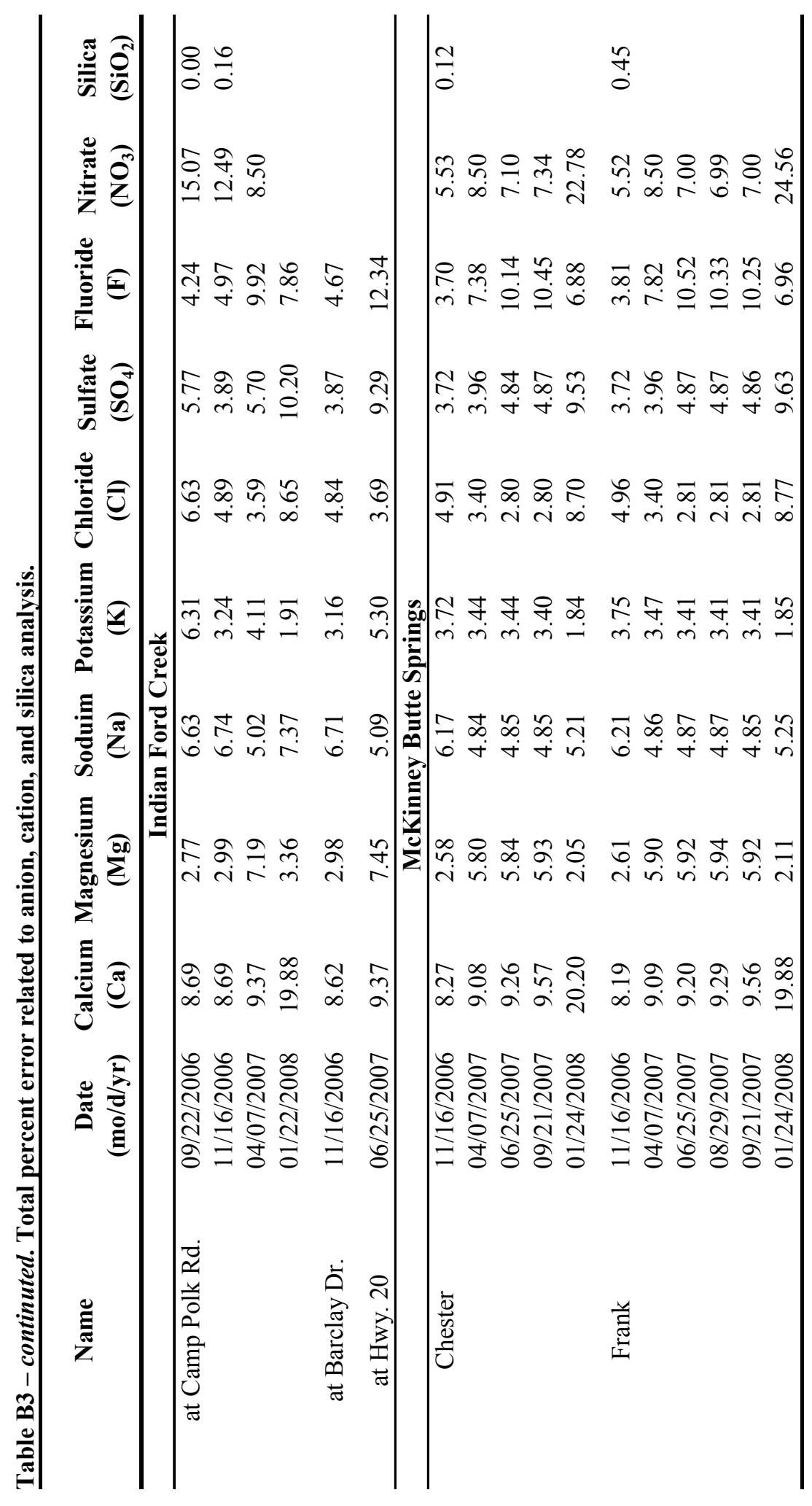




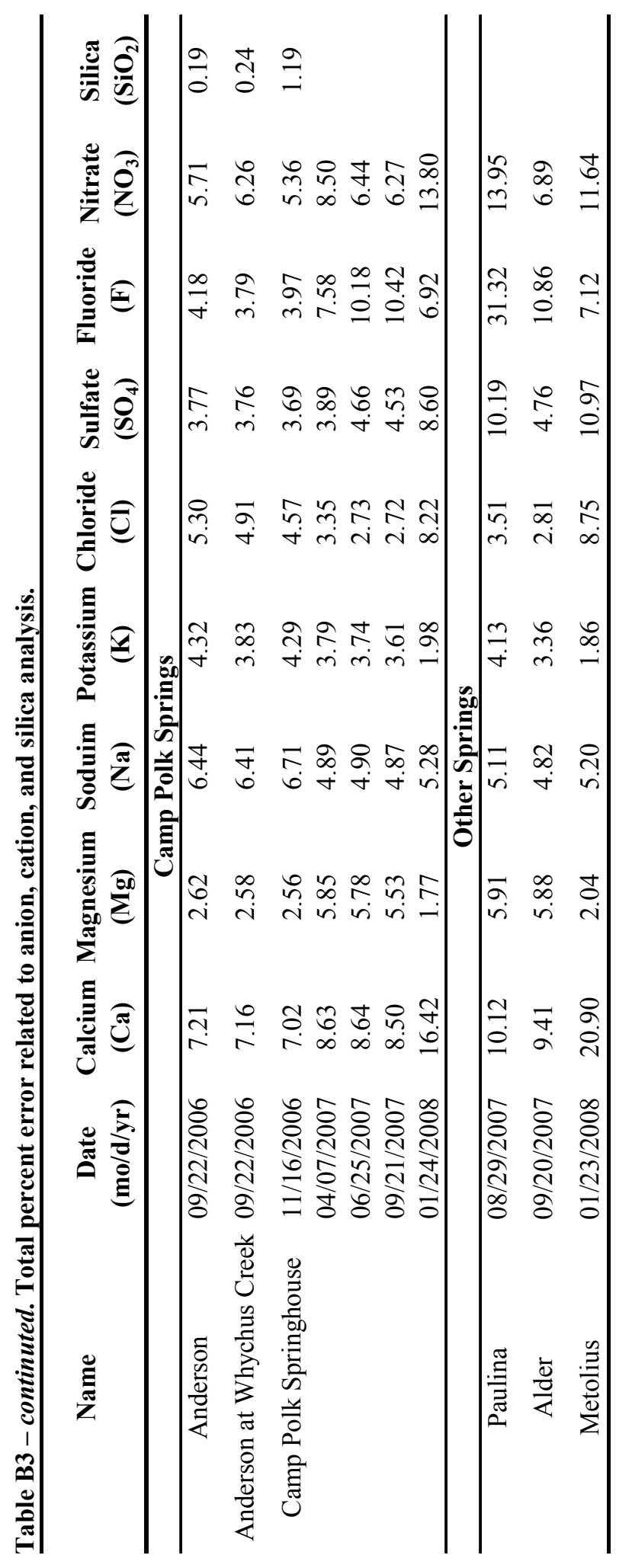




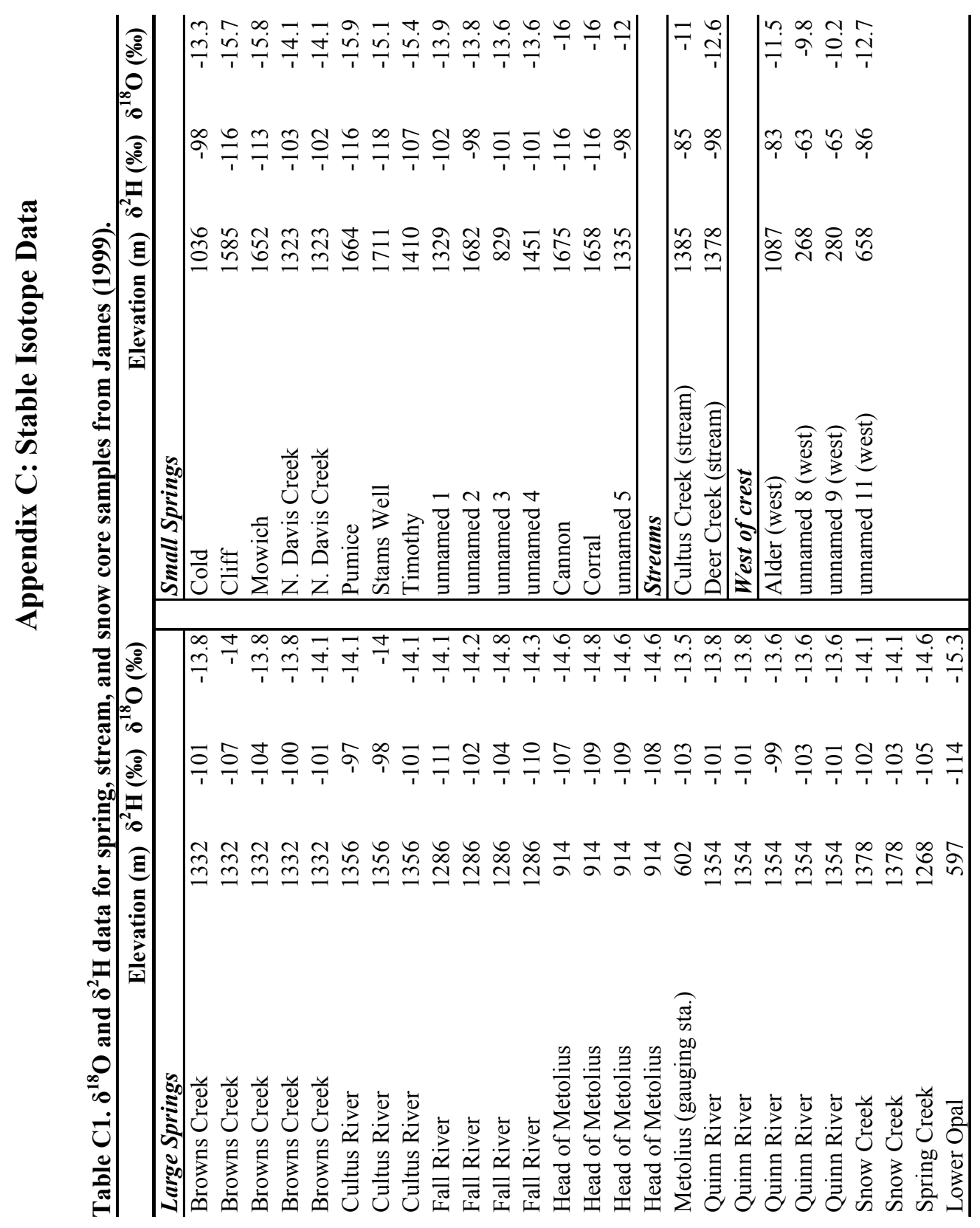

192 
Table $\mathrm{C} 1$ - Continued. $\delta^{18} \mathrm{O}$ and $\delta^{2} \mathrm{H}$ data for spring, stream, and snow core samples from James (1999).

\begin{tabular}{|c|c|c|c|c|c|c|c|}
\hline & Elevation (m) & $\delta^{2} H(\%)$ & $\delta^{18} O(\%)$ & & Elevation (m) & $\delta^{2} H(\%)$ & $\delta^{18} \mathrm{O}(\%)$ \\
\hline Snow Cores & & & & Snow Cores & & & \\
\hline 1a & 2231 & -115 & -15.2 & 17 & 1469 & -98 & -12.5 \\
\hline $1 \mathrm{~b}$ & 2231 & -105 & -14.6 & $17 \mathrm{a}$ & 1469 & -108 & -12.9 \\
\hline $1 \mathrm{c}$ & 2231 & -103 & -14.1 & $17 \mathrm{~b}$ & 1469 & -106 & -13.5 \\
\hline $2 a$ & 2060 & -108 & -14.4 & $17 \mathrm{c}$ & 1469 & -100 & -12.4 \\
\hline $2 b$ & 2060 & -102 & -14.3 & $17 d$ & 1469 & -92 & -10.9 \\
\hline $2 \mathrm{c}$ & 2060 & -109 & -14.4 & 18 & 1457 & -104 & -14 \\
\hline $3 a$ & 1939 & -115 & -14.7 & $18 \mathrm{a}$ & 1457 & -118 & -14.8 \\
\hline $3 b$ & 1939 & -99 & -12.8 & $18 \mathrm{~b}$ & 1457 & -107 & -13.4 \\
\hline $3 c$ & 1939 & -107 & -14.4 & 19 & 1463 & -112 & -14.1 \\
\hline $4 a$ & 1829 & -112 & -14.3 & 20 & 1445 & -117 & -14.5 \\
\hline $4 \mathrm{~b}$ & 1829 & -110 & -13.8 & $21 \mathrm{a}$ & 1390 & -112 & -14.4 \\
\hline $4 c$ & 1829 & -103 & -12.8 & $21 b$ & 1390 & -97 & -13 \\
\hline $5 a$ & 2438 & -106 & -14.8 & $21 \mathrm{c}$ & 1390 & -111 & -13.8 \\
\hline $5 b$ & 2438 & -108 & -15.6 & $21 d$ & 1390 & -105 & -13 \\
\hline $5 c$ & 2438 & -84 & -12.8 & 22 & 1366 & -112 & -13.9 \\
\hline $6 a$ & 2292 & -102 & -14.9 & 23 & 1361 & -116 & -14.4 \\
\hline $6 \mathrm{~b}$ & 2292 & -129 & -17.9 & 24 & 1361 & -113 & -14.3 \\
\hline $6 c$ & 2292 & -115 & -16.1 & 25 & 1372 & -114 & -13.9 \\
\hline $7 \mathrm{a}$ & 2231 & -81 & -11.3 & $25 \mathrm{a}$ & 1372 & -113 & -14.7 \\
\hline $7 b$ & 2231 & -102 & -14.1 & $25 \mathrm{~b}$ & 1372 & -104 & -13.4 \\
\hline $7 \mathrm{c}$ & 2231 & -102 & -17.9 & $25 \mathrm{c}$ & 1372 & -107 & -13.9 \\
\hline $8 \mathrm{a}$ & 2109 & -113 & -15.2 & 26 & 1410 & -111 & -13.8 \\
\hline $8 b$ & 2109 & -126 & -16.8 & $26 \mathrm{a}$ & 1410 & -112 & -14.8 \\
\hline $8 \mathrm{c}$ & 2109 & -99 & -13.9 & $26 \mathrm{~b}$ & 1410 & -99 & -13 \\
\hline $9 \mathrm{a}$ & 1859 & -106 & -14.1 & $26 c$ & 1410 & -104 & -13.5 \\
\hline $9 b$ & 1859 & -106 & -14.2 & 27 & 1457 & -92 & -12.3 \\
\hline $9 \mathrm{c}$ & 1859 & -117 & -15.4 & 28 & 1457 & -96 & -12.7 \\
\hline $10 \mathrm{a}$ & 1768 & -109 & -14.1 & 29 & 1439 & -90 & -12.1 \\
\hline $10 \mathrm{~b}$ & 1768 & -101 & -13.8 & 30 & 1439 & -96 & -12.4 \\
\hline $10 \mathrm{c}$ & 1768 & -107 & -14.5 & 31 & 1451 & -100 & -12.9 \\
\hline 11 & 1561 & -100 & -12.7 & 32 & 1280 & -99 & -12.7 \\
\hline 12 & 1561 & -106 & -13.4 & 33 & 1146 & -92 & -12.1 \\
\hline 13 & 1561 & -98 & -12.6 & 35 & 1587 & -122 & -16.3 \\
\hline 14 & 1554 & -77 & -10.7 & 36 & 1667 & -113 & -14.9 \\
\hline 15 & 1463 & -97 & -12.4 & 37 & 1746 & -106 & -14.1 \\
\hline \multirow[t]{2}{*}{16} & 1469 & -103 & -13.5 & 38 & 1926 & -107 & -14 \\
\hline & & & & 39 & 1585 & -108 & -14.1 \\
\hline
\end{tabular}


Table C2. $\delta^{18} \mathrm{O}$ and $\delta^{2} \mathrm{H}$ data for spring, stream, and well samples from Ingebritsen et al. (1988).

\begin{tabular}{|c|c|c|c|}
\hline & Elevation (m) & $\delta^{2} H(\%)$ & $\delta^{18} \mathrm{O}(\%)$ \\
\hline unnamed spring & 1658 & -90 & -12.7 \\
\hline Sunrise Springs & 1596 & -97 & -13.7 \\
\hline unnamed spring & 512 & -111 & -14.2 \\
\hline unnamed spring & 488 & -104 & -13.7 \\
\hline Mt. Hood N.F. well & 1676 & -85 & -12.3 \\
\hline unnamed spring & 1219 & -95 & -13.4 \\
\hline Harvey \& Jensen well & 546 & -101 & -13.5 \\
\hline Lichtenberger well & 642 & -102 & -14.0 \\
\hline Thompson well & 664 & -107 & -13.2 \\
\hline unnamed spring & 620 & -103 & -12.9 \\
\hline unnamed spring & 1167 & -93 & -13.2 \\
\hline Coyote Spring & 832 & -106 & -13.7 \\
\hline Nena Spring & 814 & -107 & -14.5 \\
\hline Nellie Spring & 843 & -105 & -14.3 \\
\hline unnamed spring & 433 & -104 & -13.3 \\
\hline unnamed spring & 923 & -99 & -12.8 \\
\hline unnamed spring & 555 & -117 & -14.3 \\
\hline unnamed spring & 418 & -110 & -13.2 \\
\hline unnamed spring & 823 & -103 & -12.8 \\
\hline unnamed spring & 1183 & -103 & -14.5 \\
\hline $\begin{array}{l}\text { Seymore Springs } \\
\text { unnamed spring }\end{array}$ & $\begin{array}{l}882 \\
536\end{array}$ & $\begin{array}{l}-103 \\
-118\end{array}$ & $\begin{array}{l}-13.6 \\
-14.8\end{array}$ \\
\hline unnamed stream & 1999 & -105 & -14.2 \\
\hline unnamed lake & 2182 & -100 & -14.5 \\
\hline unnamed stream & 2185 & -84 & -12.2 \\
\hline unnamed stream & 1902 & -94 & -13.0 \\
\hline Parker Creek & 1658 & -104 & -14.7 \\
\hline unnamed spring & 1597 & -100 & -13.8 \\
\hline Milk Creek & 1902 & -109 & -14.7 \\
\hline unnamed stream & 1902 & -103 & -14.5 \\
\hline unnamed stream & 1686 & -94 & -13.4 \\
\hline unnamed stream & 1768 & -96 & -13.8 \\
\hline unnamed spring & 1530 & -95 & -13.1 \\
\hline unnamed spring & 1658 & -104 & -14.2 \\
\hline Peters Spring & 937 & -107 & -13.7 \\
\hline unnamed spring & 1878 & -96 & -13.2 \\
\hline unnamed spring & 1731 & -97 & -13.3 \\
\hline
\end{tabular}


Table $\mathrm{C} 2$ - Continued. $\delta^{18} \mathrm{O}$ and $\delta^{2} \mathrm{H}$ data for spring, stream, and well samples from Ingebritsen et al. (1988).

\begin{tabular}{lrrr}
\hline & Elevation $\mathbf{( m )}$ & $\boldsymbol{\delta}^{\mathbf{2}} \mathbf{H}(\mathbf{\%})$ & $\boldsymbol{\delta}^{\mathbf{1 8}} \mathbf{O} \mathbf{( \% )}$ \\
\hline Pipp Spring & 689 & -107 & -13.6 \\
Monner Spring & 850 & -99 & -12.3 \\
North Combs Spring & 889 & -116 & -13.2 \\
unnamed spring & 1090 & -106 & -12.3 \\
unnamed spring & 1292 & -106 & -13.9 \\
Lovegren well & 1061 & -90 & -12.7 \\
Blue Lake & 1067 & -93 & -12.6 \\
Blue Lake & 1067 & -91 & -12.7 \\
Blue Lake & 1067 & -90 & -12.6 \\
Blue Lake & 1067 & -94 & -13.0 \\
Blue Lake & 1067 & -92 & -13.0 \\
Metolius Spring & 914 & -108 & -14.8 \\
Clevenger well & 805 & -99 & -13.3 \\
Cold Spring & 1036 & -97 & -13.2 \\
Indian Ford L\&C Co. W. & 975 & -93 & -12.9 \\
unnamed spring & 779 & -114 & -14.7 \\
well & 921 & -107 & -13.5 \\
well & 920 & -106 & -13.9 \\
unnamed spring & 1154 & -113 & -13.7 \\
Melvin Spring & 1329 & -115 & -15.0 \\
Black Pine Spring & 1317 & -111 & -14.8 \\
well & 1000 & -114 & -14.9 \\
Picket Spring & 1214 & -116 & -15.0 \\
unnamed spring & 2410 & -116 & -13.6 \\
Bull Spring & 1164 & -108 & -14.6 \\
unnamed spring & 1710 & -103 & -14.0 \\
unnamed spring & 1710 & -96 & -14.0 \\
unnamed spring & 1710 & -96 & -14.1 \\
unnamed spring & 1414 & -99 & -14.1 \\
Kiwa Spring & 1460 & -114 & -15.1 \\
Coyote Spring & 1416 & -112 & -15.6 \\
unnamed spring & 1372 & -111 & -14.2 \\
unnamed spring & 1274 & -112 & -14.6 \\
well & 1271 & -109 & -15.6 \\
Sand Spring & 1506 & -100 & -9.1 \\
unnamed spring & 1329 & -87 & -11.8 \\
\hline & & & \\
& &
\end{tabular}


Table C3. $\delta^{18} \mathrm{O}$ and $\delta^{2} \mathrm{H}$ data for spring and well samples from Caldwell (1998).

\begin{tabular}{lrrr}
\hline & Elevation (m) & $\boldsymbol{\delta}^{\mathbf{2}} \mathbf{H}(\mathbf{\%})$ & $\boldsymbol{\delta}^{\mathbf{1 8}} \mathbf{O}(\mathbf{\% o})$ \\
\hline Springs & & & \\
\hline Lower Opal Springs & 597 & -114.0 & -15.28 \\
Virgin River Springs & 677 & -114.0 & -15.10 \\
Alder Springs & 695 & -111.0 & -14.81 \\
Paulina Springs & 1024 & -92.1 & -12.84 \\
Source Springs & 1928 & -101.0 & -14.20 \\
Springs River Springs & 1273 & -109.0 & -14.44 \\
\hline Wells & & & \\
\hline JEFF 221 & 547 & -112.0 & -13.42 \\
JEFF 231 & 596 & -113.0 & -13.58 \\
JEFF 538 & 901 & -115.0 & -14.45 \\
JEFF 164 & 873 & -105.0 & -13.62 \\
DESC 1800 & 1023 & -92.6 & -13.01 \\
DESC 1510 & 946 & -110.0 & -13.89 \\
DESC 2498 & 897 & -95.9 & -12.57 \\
DESC 2498 & 897 & -98.2 & -12.56 \\
DESC 3951 & 931 & -115.0 & -15.46 \\
DESC 4320 & 971 & -98.8 & -13.11 \\
DESC 4320 & 971 & -98.4 & -13.19 \\
DESC 4413 & 973 & -98.5 & -13.03 \\
DESC 4413 & 973 & -99.7 & -13.13 \\
DESC 4844 & 1045 & -95.0 & -12.79 \\
DESC 4844 & 1045 & -100.0 & -13.04 \\
DESC 5045 & 1055 & -110.0 & -14.66 \\
DESC 5180 & 1023 & -96.2 & -12.70 \\
DESC 5180 & 1023 & -96.8 & -12.75 \\
DESC 5750 & 1091 & -124.0 & -15.58 \\
DESC 5752 & 1299 & -122.0 & -15.65 \\
\hline
\end{tabular}

